FÁBIO MACHADO MALAGÓ

\title{
Distribuição dinâmica do ônus da prova
}

\author{
DisSERTAÇÃo DE MESTRAdO \\ Orientador: Prof. DOUTOR HeItor Vitor MENdONÇa SiCA
}

UNIVERSIDADE DE SÃO PAULO

FACULDADE DE DIREITO

SÃO PAULO 


\section{Distribuição dinâmica do ônus da prova}

Dissertação de Mestrado apresentada à Banca Examinadora da Faculdade de Direito da Universidade de São Paulo, como exigência parcial para a obtenção do título de Mestre em Direito, na área de concentração Direito Processual Civil, sob a orientação do Prof. Dr. Heitor Vitor Mendonça Sica.

UNIVERSIDADE DE SÃO PAULO

FACULDADE DE DIREITO

SÃO PAULO 
Autorizo a reprodução e divulgação parcial deste trabalho, por qualquer meio convencional ou eletrônico, para fins de estudo e pesquisa, desde que citada a fonte.

\section{Serviço de Biblioteca e Documentação}

\section{Faculdade de Direito da Universidade de São Paulo}

\section{Malagó, Fábio Machado}

M 196d Distribuição dinâmica do ônus da prova / Fábio

Machado Malagó . -- São Paulo: USP / Faculdade de Direito, 2014.

$260 \mathrm{f}$.

Orientador: Prof. Dr. Heitor Vitor Mendonça Sica

Dissertação (Mestrado), Universidade de São Paulo, USP, Programa de Pós-Graduação em Direito, Direito Processual, 2014.

1. Ônus da prova. 2. Prova (Processo civil). 3.Flexibilização. I. Sica, Heitor Vitor Mendonça. II. Título. 
MALAGÓ, Fábio Machado. Distribuição dinâmica do ônus da prova. Dissertação de Mestrado apresentada à Banca Examinadora da Faculdade de Direito da Universidade de São Paulo, como exigência parcial para a obtenção do título de Mestre em Direito, na área de concentração Direito Processual Civil.

Aprovado em:

BANCA EXAMINADORA:

Orientador:

Nome: Prof. Dr. Heitor Vitor Mendonça Sica

Instituição: Faculdade de Direito da Universidade de São Paulo

Julgamento:

Professor Arguidor:

Nome:

Instituição:

Julgamento:

Professor Arguidor:

Nome:

Instituição:

Julgamento: 
À Mirian, minha esposa, fonte de inspiração e amor verdadeiro. 


\section{AGRADECIMENTOS}

O primeiro agradecimento é para minha esposa Mirian, pela paciência, pela compreensão nos momentos em que não pude estar presente, pelo apoio nas horas mais difíceis, e pela dedicação e amor à nossa família.

Agradeço aos meus pais, Arnaldo e Marialice, pelo apoio incondicional, desde sempre, e principalmente quando saí de casa para fazer o curso de graduação no Largo de São Francisco, dando-me todo o suporte necessário para ser a pessoa que sou hoje, e me mostrando como a integridade e amor são armas poderosas para construir uma família.

Também quero agradecer ao meu irmão Rafael, meu primeiro amigo e companheiro de todas as horas, que sempre me apoiou e incentivou.

Aos meus familiares, em especial à minha madrinha, Gláucia Maria Machado Santelli, Professora titular do Instituto de Ciências Biomédicas da Universidade de São Paulo, exemplo de força e dedicação à vida acadêmica, por todo o suporte, carinho e incentivo aos estudos.

Aos meus amigos, em especial aqueles que conheci no curso de graduação e que levarei para toda a vida, aqui representados pelo meu compadre Renato Rodrigues Costa Galvano, a quem tive a honra de apadrinhar em seu casamento e em também no batismo de sua filha Helena, amigo de todas as horas e que contribuiu de forma decisiva para a realização deste trabalho, com sugestões, discussões e revisão de texto.

Ao Professor Doutor Heitor Sica, que acreditou neste sonho que ora se realiza e que, com seu conhecimento e perspicácia ímpares, permitiu que este trabalho se estruturasse e se concretizasse, guiando-me pelo caminho do rigor técnico e científico que o curso de Mestrado exige.

Ao advogado, sócio e amigo Pedro Romeiro Hermeto, por ter acreditado desde a época de estágio em minha capacidade e por sempre mostrar como o pensamento simples e direto é capaz de dar as melhores soluções, seja no âmbito profissional ou pessoal, além de todo o apoio dado para superar mais essa etapa da minha formação e jamais deixar me acomodar. Ao também advogado, sócio e amigo, Daniel Ostronoff, pela confiança e inquietações, que nos permitem pensar adiante, e contribuem na consolidação de nossa parceria, que espero seja duradoura.

Por fim, agradeço a todos que direta ou indiretamente contribuíram para a viabilização, os quais seriam impossíveis de enumerar, mas que por certo merecem o meu reconhecimento. 
A arte do processo não é senão a arte de administrar as provas.

JEREMY BENTHAM

La realidad - como la vida - no está trazada de una vez y para siempre ni de manera uniforme. El querer abrazar a todos los casos y manejarlos en rígidas reglas se ve que es imposible y si se fuerza a ello, esa compleja realidad se vengará de las doctrinas y de las normas. Ninguna de ellas, por lo demás, es el final del camino. 
MALAGÓ, Fábio Machado. Distribuição dinâmica do ônus da prova. 2014. 260 f. Dissertação (Mestrado) - Faculdade de Direito, Universidade de São Paulo, São Paulo, 2014.

\section{RESUMO}

A presente dissertação tem por objetivo examinar uma técnica de flexibilização da distribuição do ônus da prova, denominada distribuição dinâmica do ônus da prova. Tratase de técnica aplicável de forma subsidiária à regra geral e abstrata prevista no Código de Processo Civil, em processos em que as partes litigantes se encontram em situação de desigualdade, sobretudo quanto à capacidade de produzir prova. São hipóteses que podem até mesmo inviabilizar o acesso da parte onerada ao Poder Judiciário, diante da impossibilidade ou extrema dificuldade de fazer prova das alegações de fato que fundamentam as suas pretensões, ao passo que o seu adversário apresenta-se plenamente capacitado para produzir a prova do fato contrário. $\mathrm{Na}$ primeira parte do trabalho examinaremos a relevância da adequada instrução probatória para a obtenção de uma tutela jurisdicional justa, passando, em seguida, à conceituação do ônus da prova e sua dupla função desenvolvida no processo, com prevalência da função subjetiva, direcionada às partes, na busca da apuração do ônus da prova. Na sequência, examinaremos a distribuição do ônus da prova, seus fundamentos, a importância da constatação da capacidade probatória das partes e a evolução dos critérios de distribuição do ônus da prova, desde as fontes romanas até o modelo vigente no Código de Processo Civil e outras técnicas mais modernas. Segue-se o estudo com o exame das técnicas de modificação do ônus da prova previstas no Código de Defesa do Consumidor, correlatas à técnica dinâmica, para, enfim, tratarmos do tema central desta dissertação, a distribuição dinâmica do ônus da prova, expondo as bases axiológicas para sua ampliação, suas características essenciais e requisitos condicionantes, de modo a nos permitir formular uma regra de aplicabilidade, bem como sustentar sua recepção pelo direito pátrio, ainda que de lege ferenda, sem prejuízo do exame da proposta legislativa contida no projeto do novo Código de Processo Civil. Por fim, diante da necessidade de definição da relevância da técnica dinâmica para o processo, faremos um exame de julgados em que a técnica foi empregada, e a sua confrontação com outros meios de flexibilização da distribuição do ônus da prova e os meios de prova típicos, que nos possibilitará concluir qual é o real campo de incidência da técnica de distribuição dinâmica do ônus da prova.

Palavras-chave: Ônus da prova, distribuição do ônus da prova, técnica processual, flexibilização, distribuição dinâmica do ônus da prova. 
MALAGÓ, Fábio Machado. Dynamic distribution of the burden of proof. 2014. $260 \mathrm{f}$. Dissertation (MA) - Law School, Universidade de São Paulo, São Paulo, 2014.

\begin{abstract}
This dissertation examines a more flexible technique for the distribution of the burden of proof, called dynamics distribution of the burden of proof. This technique is subsidiarily applicable to the general and abstract rule of the Code of Civil Procedure, in actions where the litigating parties have an unequal standing, especially with respect to their ability to produce evidence. This can even render access to Justice unfeasible for the aggrieved party, in view of the impossibility or extreme difficulty in substantiating the arguments of fact that ground the claim, while the adversary party is fully capable of producing proof to the contrary. The first part of the paper will examine the relevance of adequate discovery for fair relief. It will then proceed to conceptualize burden of proof and its twofold function in suits, with prevalence of the subjective function in determining the burden of proof. Next, it will examine the distribution of the burden of proof, its fundaments, the importance of verification of the parties' capacity to prove, from Roman Law to the model in force in the Code of Civil Procedure and other more modern techniques. Subsequently, it will review the techniques of inversion of the burden of proof established in the Consumer Defense Code, correlated to the dynamic technique, to finally address the central theme of the dissertation, namely, the dynamic distribution of the burden of proof, the axiological bases for its extension, its essential features and conditioning requirements. This enables the formulation of a rule of applicability and how it was received in Brazilian law, albeit "de lege ferenda", without prejudice of examining the legislative proposal contained in the Bill of Law of the new Code of Civil Procedure. Finally, in light of the need to define the relevance of the dynamic technique for lawsuits, some court decisions in which the technique was employed will be analyzed and compared to other means of more flexible distribution of the burden of proof and typical means of proof. This will lead to the discussion of the real field of incidence of the technique of dynamic distribution of the burden of proof.
\end{abstract}

Keywords: Burden of proof, distribution of the burden of proof, procedural technique, making more flexible, dynamic distribution of the burden of proof. 


\section{SUMÁRIO}

INTRODUÇÃO

CAPÍTULO 1 - COGNIÇÃO, PROVA E TUTELA JURISDICIONAL ................ 22

1.1. Objeto da cognição e finalidade da prova ..................................................... 22

1.2. Prova, partes e poderes instrutórios do juiz ................................................. 28

1.3. Direito à prova como garantia constitucional ............................................... 34

1.4. Verdade, certeza, probabilidade, verossimilhança e dúvida ......................... 39

1.5. Conclusão deste capítulo: relevância da correta instrução probatória na busca da tutela jurisdicional justa

CAPÍTULO 2 - ÔNUS DA PROVA

2.1. Ônus $x$ obrigação $x$ dever: necessidade de uma distinção ............................ $\quad 49$

2.2. Conceito e alcance do ônus da prova ......................................................... 54

2.3. Técnica processual: as funções do ônus da prova ....................................... 57

2.3.1. Função subjetiva do ônus da prova ............................................ 58

2.3.2. Função objetiva do ônus da prova .................................................... 61

2.3.3. Conclusão deste capítulo: prevalência da função subjetiva do ônus da prova como técnica de descoberta da verdade

CAPÍTULO 3 - DISTRIBUIÇÃO DO ÔNUS DA PROVA

3.1. Fundamentos para a distribuição do ônus da prova ...................................... 68

3.2. Capacidade probatória e prova diabólica ..................................................... $\quad 74$

3.3. Critérios "estáticos” de distribuição do ônus da prova ................................... 80

3.3.1. Ônus da prova incumbe ao autor ................................................ 80

3.3.2. Ônus incumbe à parte que afirma o fato, na ação ou na exceção, como autor ou réu

3.3.3. Ônus da prova incumbe a quem afirma, não a quem nega ..............

3.3.4. Ônus da prova incumbe ao autor e ao réu quanto aos fatos que fundamentam as suas pretensões ................................................ $\quad 86$

3.3.5. Ônus distribuído pela regra da normalidade ................................. 87

3.3.6. Ônus da prova incumbe a quem pretende inovar .......................... 89

3.3.7. Ônus distribuído pela regra da natureza dos fatos ......................... $\quad 90$ 
3.3.8. Ônus distribuído pela regra das normas ....................................... 92

3.3.9. Ônus distribuído pela regra dos efeitos jurídicos perseguidos ....... 94

3.3.10. Ônus distribuído pela regra das normas + regra dos efeitos jurídicos perseguidos ............................................................... 96

3.4. Modelo vigente no Código de Processo Civil de 1973 ................................ 96

3.5. Insuficiência do modelo vigente no Código de Processo Civil de $1973 \ldots \ldots . . \quad 101$

3.6. Critérios "dinâmicos" de distribuição do ônus da prova ............................... 107

\section{CAPÍTULO 4 - DISTRIBUIÇÃO DO ÔNUS DA PROVA NOS PROCESSOS} QUE ENVOLVEM RELAÇÕES CONSUMERISTAS

4.1. Quanto à utilidade do estudo da técnica de distribuição do ônus da prova nos processos que envolvem relações consumeristas

4.2. Crítica à expressão "inversão do ônus da prova" utilizada no Código de Defesa do Consumidor

4.3. Hipóteses de redistribuição legal do ônus da prova

4.4. Hipótese de redistribuição judicial do ônus da prova

4.4.1. Características fundamentais

4.4.2. Requisitos condicionantes ao emprego da técnica de redistribuição do ônus da prova

4.4.3. Momento e limites da aplicação da redistribuição judicial do ônus da prova

4.4.4. Redistribuição do ônus da prova e adiantamento das despesas processuais

CAPÍTULO 5 - DISTRIBUIÇÃO DINÂMICA DO ÔNUS DA PROVA

5.1. Pressupostos axiológicos da técnica de distribuição dinâmica do ônus da prova

5.1.1. Processo civil constitucional

5.1.2. Dever processual de colaboração na obtenção da prova

5.1.3. Dever processual de lealdade das partes

5.2. Características fundamentais

5.2.1. Dinamismo

5.2.2. Subsidiariedade à regra estática de distribuição do ônus da prova e aos poderes instrutórios do juiz 
5.2.3. Excepcionalidade

5.2.4. Capacidade das partes de produzir provas .................................... 156

5.2.5. Irrelevância da posição das partes na relação processual ................ 160

5.2.6. Irrelevância da natureza do fato a ser provado .............................. 162

5.3. Requisitos condicionantes ao emprego da técnica de distribuição dinâmica do ônus da prova

5.3.1. Inviabilidade do uso da técnica geral e abstrata

5.3.2. Desigualdade na capacidade de produzir prova e a vedação da prova diabólica (direta ou inversa)

5.3.3. Inexistência da culpa da parte onerada pela extrema dificuldade ou impossibilidade de produzir prova

5.3.4. Verossimilhança das alegações de fato

5.3.5. Inviabilidade do uso de outros meios de flexibilização da distribuição do ônus da prova e/ou dos poderes instrutórios do juiz

5.3.6. Necessidade de decisão adequadamente fundamentada

5.3.7. Necessidade do efetivo contraditório

5.3.8. Oportunidade para a parte se desonerar

5.4. Momento da aplicação da distribuição dinâmica do ônus da prova

5.5. Distribuição dinâmica do ônus da prova e adiantamento das despesas processuais

5.6. Tentativa de se formular uma definição para a regra de aplicabilidade da técnica de distribuição dinâmica do ônus da prova

5.7. Aplicabilidade da técnica da distribuição dinâmica do ônus da prova à luz do Código de Processo Civil de 1973

5.8. Inclusão da técnica da distribuição dinâmica do ônus da prova no projeto do novo Código de Processo Civil

5.9. Comparação entre as técnicas de distribuição dinâmica do ônus da prova e de redistribuição judicial do ônus da prova prevista no Código de Defesa do Consumidor

5.10. Poderes instrutórios do juiz, imparcialidade e influência sobre a distribuição dinâmica do ônus da prova 
CAPÍTULO 6 - INCIDÊNCIA PRÁTICA DA TÉCNICA DE DISTRIBUIÇÃO DINÂMICA DO ÔNUS DA PROVA NO PROCESSO CIVIL ............................. 204

6.1. Quanto à pertinência do estudo prático ........................................................ 204

6.2. Exame jurisprudencial de aplicação da técnica de distribuição dinâmica do ônus da prova ..................................................................................... 205

6.3. Presunções legais decorrentes de comportamentos omissivos dos litigantes .................................................................................... 215

6.3.1. Exibição de documento ou coisa ................................................. 219

6.3.2. Perícia médica ........................................................................ 224

6.3.3. Interrogatório, depoimento pessoal e confissão ficta ..................... 229

6.4. Distribuição do ônus da prova por convenção entre as partes ..................... 233

6.5. Dinamização da distribuição do ônus da prova e os meios de prova disponíveis ..................................................................................... 236

6.6. Distribuição dinâmica do ônus da prova e os modelos de constatação .......... 239

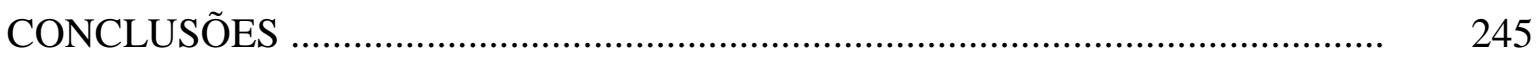




\section{INTRODUÇÃO}

Os estudos sobre o ônus da prova e sua distribuição na doutrina pátria, desde a clássica lição de S. SOARES DE FARIA ${ }^{1}$ para provimento de Cátedra na Faculdade de Direito da Universidade de São Paulo, têm dado especial enfoque aos aspectos dogmáticos do instituto, repetindo, de forma quase que unicamente descritiva, os diversos critérios que ao longo dos anos foram desenvolvidos pela doutrina (em sua maioria estrangeira) para se determinar a forma de distribuição do ônus da prova, e ressaltando apenas a sua função como regra de julgamento destinada ao magistrado quando não lhe for possível formar um juízo de convicção sobre as alegações de fato controvertidas, por ausência ou insuficiência de provas.

Embora a revisitação ontológica dos critérios de distribuição seja relevante para a compreensão de sua evolução e para a consolidação do modelo vigente, e a atividade-fim da distribuição do ônus da prova seja algo inevitável diante do estado de dúvida do juiz, em face da impossibilidade de pronunciar um non liquet, o tema comporta outras relevantes variações, sobretudo, quando observado a partir de uma visão teleológica do processo. ${ }^{2}$

No atual estágio de desenvolvimento do processo civil, a técnica de distribuição do ônus da prova não pode mais ser empregada apenas como um mecanismo formal de solução de litígios diante do não convencimento do magistrado quanto às questões fáticas em discussão, embora, logicamente, não seja possível descartar por completo essa função.

Como demonstraremos ao longo do presente trabalho, o processo civil moderno exige uma atuação mais ativa do magistrado perante os litígios que deve julgar, preocupado em dar uma resposta tempestiva, justa e efetiva às partes envolvidas em uma

\footnotetext{
1 Principaes theorias relativas ao onus probandi. São Paulo: RT, 1936.

2 A visão teleológica do processo, também denominado processo civil de resultados, que, como adverte Cândido Rangel Dinamarco, é a consciência de que o sistema processual deve ser dotado de mecanismos que permitam um resultado útil àquele que tem razão no litígio (autor ou réu), como reflexo do interesse coletivo de pacificação com justiça e para sua própria legitimação como ato de exercício do poder pelo Estado (Instituições de direito processual civil. São Paulo: Malheiros, 2001. v. 1, p. 108).
} 
disputa judicial. ${ }^{3}$ Nesse contexto, é primordial que a instrução probatória se desenvolva da forma mais eficiente possível, e o emprego da técnica da distribuição do ônus probatório, como atividade de estruturação da prova, pode contribuir sobremaneira para tal fim, seja por meio de uma melhor orientação das partes quanto aos respectivos ônus, seja mediante a flexibilização da regra geral e abstrata contida no artigo 333 do Código de Processo Civil, redefinindo as cargas probatórias das partes a partir da análise do caso concreto.

Trata-se de analisar o mesmo instituto (ônus da prova e sua distribuição), mas a partir de outro enfoque (estruturação da prova), que, em nosso sentir, é tão ou mais importante que a atividade-fim, mormente quando se propõe a estudar o processo como um instrumento de satisfação do direito material, capaz de eliminar, com justiça, as insatisfações individuais, e promover a pacificação social, sem deixar de observar as regras postas, mas dando-lhes um novo enquadramento técnico, social e político. ${ }^{4}$

José Roberto dos SANTos Bedaque sintetiza essa visão do fenômeno processual afirmando que a utilidade do processo, como instrumento, é medida de acordo com os benefícios que este possa trazer ao titular da pretensão protegida pelo direito material, ${ }^{5}$ o qual será mais acertadamente concedido quanto melhores forem a instrução

3 Como ensina SIDNEI AMENDOEIRA JÚNIOR, a tutela será tempestiva quando “chega a tempo compatível com a natureza do objeto em litígio", justa quando "resulta da observância de todas as garantias constitucionais que visam à proteção dos jurisdicionados" e efetiva quando garantir a "entrega ao jurisdicionado detentor de um direito, do bem da vida solicitado" (Poderes do juiz e tutela jurisdicional: a utilização racional dos poderes do juiz como forma de obtenção da tutela jurisdicional efetiva, justa e tempestiva. São Paulo: Atlas, 2006. p. 30-31).

4 Para CÂNDIDO RANGEL DINAMARCO, "não se trata de desprocessualizar a ordem jurídica. É imenso o valor do processo e nas formas dos procedimentos legais estão depositados séculos de experiência que seria ingênuo querer desprezar. $\mathrm{O}$ que precisa é desmitificar regras, critérios, princípios e o próprio sistema”. (A instrumentalidade do processo. 14. ed. São Paulo: Malheiros, 2003. p. 317). No mesmo sentido, José CARlos BARBOSA MOREIRA enfatiza que o processualista, assim como o músico experiente que ao voltar a tocar uma peça de Mozart ou Beethoven já não lê mais a partitura com os mesmos olhos, "revisitando lugares vulneráveis", deve "divisar na paisagem cores até então despercebidas, e escolher as tintas adequadas para revelar novas tonalidades". (O processo civil hoje: um Congresso da Associação Internacional de Direito Processual. Reflexões sobre direito e sobre processo. Rio de Janeiro, 1992. p. 20).

5 Direito e processo. 2. ed. São Paulo: Malheiros, 1997. p. 17. Em sua tese de titularidade para a cadeira de Direito Processual na Faculdade de Direito da Universidade de São Paulo, que originou o livro Efetividade do processo e técnica processual (2. ed. São Paulo: Malheiros, 2007), o referido processualista aprofunda sua análise sobre a efetividade do processo, procurando apontar como o uso inadequado da técnica processual pode levar o processo a consequências indesejadas, entre elas, a sua extinção sem apreciação do mérito, apontando soluções para um melhor uso da técnica para que o processo possa atingir o seu objetivo. Quanto à relevância da efetividade para a instrução probatória, BARBOSA MOREIRA sustenta que ela "impende assegurar condições propícias à exata e completa reconstituição dos fatos relevantes, a fim de que o convencimento do julgador corresponda, tanto 
probatória e a formação da convicção do magistrado acerca dos fatos objeto da controvérsia.

Essa visão instrumentalista do processo leva-nos a buscar reestudar os institutos, mesmo aqueles já consagrados, para reexaminar se a técnica que vem sendo empregada naquele contexto é apta a atender aos anseios sociais, políticos e jurídicos do processo, bem como a assegurar a tutela jurisdicional plena e efetiva.

Esse trabalho de revisão de alguns dogmas processuais se torna ainda mais relevante diante da expectativa de promulgação de um novo Código de Processo Civil, ${ }^{6}$ momento oportuno para um reexame profundo da matéria, de modo que o texto normativo seja mais técnico e coerente e melhor reflita a realidade que se verifica na prática judiciária, ${ }^{7}$ tal como o tema objeto da presente dissertação, a distribuição dinâmica do ônus da prova, que vem sendo gradativamente aplicada no foro, ${ }^{8}$ embora nem sempre de forma adequada, bem como vem ganhando espaço nos debates acadêmicos.

Nesse sentido, seguindo a proposta de BEDAQUE, e procurando expandir essa revisitação dos institutos processuais para áreas que há muito não são mais bem vasculhadas e destrinchadas pela doutrina, a presente dissertação tem por objetivo analisar em que medida as técnicas ${ }^{9}$ empregadas na distribuição do ônus da prova podem ser

quanto puder, à realidade" (Efetividade do processo e técnica processual. Temas de direito processual civil: sexta série, São Paulo: Saraiva, 1997. p. 18).

6 Tratamos do Projeto de Lei $\mathrm{n}^{\circ}$ 166/2010, do Senado Federal, já aprovado na Câmara dos Deputados com modificações, atualmente tramitando no Senado Federal como Substitutivo da Câmara dos Deputados ao Projeto de Lei do Senado ${ }^{\circ}$ 166/2010, cujo parecer final, com o texto consolidado do novo Código de Processo Civil, foi apresentado em 27.11.2014 e aprovado em 04.12.2014, disponível em: <http://www.senado.gov.br/atividade/materia/getPDF.asp?t=157884\&tp=1>. Acesso em: 10 dez.2014.

7 Como ensina EDUARDO J. COUTURE, “[...] todos estamos habituados a manejar as formas do processo, seus prazos, suas condições, como se fossem fins em si mesmos. Esse ramo do direito, pois, nos surge, em sua aparência, como a forma solene, como cerimonial da Justiça. A experiência, contudo, nos ensina que isso é unicamente o invólucro do fenômeno. Por debaixo das formas existe um conteúdo profundo e angustioso, que necessita aflorar à superfície" (Introdução ao estudo do processo civil. Tradução M. V. Russomano. 3. ed. Rio de Janeiro: José Konfino, 1951. p. 15).

$8 \quad$ No item "6.2" do Capítulo 6 faremos um exame de como a técnica da distribuição dinâmica do ônus da prova tem sido empregada pelos Tribunais pátrios, dando especial relevância aos julgamentos do Superior Tribunal de Justiça.

9 É importante ter presente que os critérios pelos quais se faz a atribuição do ônus da prova não constituem uma "teoria", mas apenas o emprego de uma "técnica" calcada em certos valores e sujeita a certos requisitos condicionantes. Nesse sentido, utilizaremos sempre o termo "técnica" (ou sinônimos) quando nos referirmos às diferentes maneiras de distribuição do ônus da prova. Afinal, como lembra DinAMARCo, "mede-se o grau de desenvolvimento de uma ciência pelo refinamento 
aperfeiçoadas, especialmente, para uma melhor organização e otimização da atividade probatória, sempre com o intuito de se alcançar uma prestação jurisdicional mais condizente com a realidade dos fatos e, consequentemente, mais justa e eficaz.

Verificaremos, em especial, a proposta de remodelação da distribuição do ônus da prova pretendida pelo projeto do novo Código de Processo Civil, ${ }^{10}$ intitulada na doutrina de "distribuição dinâmica do ônus da prova", e como o emprego dessa nova técnica de atribuição do ônus da prova às partes pode contribuir para um aperfeiçoamento da instrução probatória e, eventualmente, da efetividade do processo.

Ao longo deste trabalho, apontaremos tanto os aspectos favoráveis como os desfavoráveis ao modelo dinâmico de distribuição do ônus da prova, sempre levando em consideração a técnica processual aplicada, sem perder de vista que, no propósito de se atingir um ideal de efetividade, não se podem ignorar as garantias constitucionais conquistadas e sedimentadas ao longo do tempo, em especial as do contraditório e da ampla defesa (Constituição Federal, artigo 5. ${ }^{\circ}$, inciso LV), que constituem a essência do devido processo constitucional. ${ }^{11}$

Vale destacar, ainda, que a nossa proposta não é conceber inovações abstratas e inócuas à técnica de distribuição do ônus da prova, mas analisar essencialmente se a técnica "dinâmica" de distribuição do ônus probatório é aplicável em alguma medida na prática, mesmo de lege ferenda, e em que medida é capaz de trazer contribuições relevantes do ponto de vista finalístico do processo, confrontando-a com outros mecanismos de flexibilização do ônus da prova, com os meios de prova típicos atualmente existentes e com técnicas de valoração da prova e redução do grau de convencimento para

maior ou menor de seu vocabulário específico. Onde os conceitos estão mal definidos, os fenômenos ainda confusos e insatisfatoriamente isolados, onde o método não chegou ainda a tornar claro ao estudioso de determinada ciência, é natural que ali também seja pobre a linguagem e as palavras se usem sem grande precisão técnica" (Fundamentos do processo civil moderno. 2. ed. São Paulo: Malheiros, 1987. v. 1, p. 101-102).

10 O artigo 370 do citado Projeto, com as modificações do Substitutivo, regula a matéria sobre distribuição do ônus da prova, repetindo em sua parte inicial as disposições contidas no artigo 333 do Código de Processo Civil e trazendo nos seus parágrafos a hipótese de aplicação da técnica de distribuição dinâmica do ônus da prova. No item "5.8" do Capítulo 5 discorreremos mais detidamente sobre a redação projetada.

11 Nesse sentido é a lição de CALMON DE PASSOS (Instrumentalidade do processo e devido processo legal. Revista Forense, Rio de Janeiro: Forense, v. 96, n. 351, p. 107, jul.-set. 2000). 
tomada de decisão, destinando atenção especial ao aspecto prático, a partir do posicionamento doutrinário e jurisprudencial sobre o tema.

O ponto de partida que nos levou ao aprofundamento do tema é a percepção, cada vez mais evidente, de que o modelo atual de distribuição do ônus da prova, calcado na tortuosa distinção entre fatos constitutivos, extintivos, modificativos e impeditivos, e na promessa de igualdade formal das partes no processo (autor ou réu), nos termos dos artigos 333 e 125 do Código de Processo Civil, mostra-se incapaz de dar uma solução justa em casos excepcionais, em que as particularidades do direito material em debate ou a condição das partes diante das alegações de fato a serem provadas evidenciam uma desigualdade material nas respectivas capacidades probatórias, de modo que a regra geral e abstrata de distribuição do ônus da prova não serve como técnica adequada para fornecer um arcabouço probatório capaz de solucionar satisfatoriamente todos os litígios levados ao conhecimento do juiz.

Com efeito, em diversas oportunidades nos deparamos com sentenças fundadas exclusivamente na regra de distribuição do ônus da prova em desfavor de uma das partes (seja autor ou réu), ainda que no caso concreto a verossimilhança das alegações da parte sucumbente seja patente, mas essa parte, por determinadas circunstâncias, não foi capaz de reunir os elementos probatórios que dessem sustentação à sua pretensão a ponto de o magistrado responsável pelo julgamento formar sua convicção.

Essas sentenças, ainda que formalmente perfeitas, ignoram as possíveis desigualdades existentes entre as partes (e as eventuais dificuldades no acesso e na produção das provas), que, se fossem minimizadas, seja com o emprego dos poderes instrutórios do juiz ou com uma redefinição dos ônus probatórios das partes, poderiam permitir um aprofundamento na descoberta dos fatos que embasam as pretensões das partes, de modo a se chegar a uma decisão mais próxima da solução concreta prevista na norma jurídica aplicável à espécie.

Da mesma forma, ao tomar a técnica de distribuição do ônus da prova apenas como regra de julgamento, o magistrado deixa de dar pleno atendimento aos escopos do processo, pois, sem uma solução de mérito calcada na comprovação das alegações de fato, a pacificação social fica comprometida, sobretudo no seu caráter educacional. 
Para tentar dirimir essas situações, é imprescindível que o sistema processual esteja dotado de mecanismos alternativos (simples ou subsidiários) de obtenção da prova (seja para confirmar a alegação de fato ou para negá-la), o que pode ser realizado, por exemplo, com os poderes instrutórios do juiz ou, quando estes não se mostrarem pertinentes ou cabíveis, com o deslocamento das cargas probatórias, como se propõe na técnica de distribuição dinâmica do ônus probatório, em que se atribui ônus de provar a uma das partes, que originalmente não estava onerada, com o respectivo deslocamento do objeto da prova (da alegação de fato da parte inicialmente onerada para a oposição ${ }^{12}$ de fato formulada pela parte contrária).

A proposta de redistribuição do ônus da prova com base na técnica dinâmica tem por objetivo primordial a ampliação da cognição do juiz sobre os fatos relevantes para o julgamento, pois amplia a instrução e a produção de provas sobre determinadas alegações de fato que seriam impossíveis ou muito difíceis de ser realizadas pela parte originalmente onerada, tentando, assim eliminar (ou ao menos tentar reduzir) a prolação de sentenças de mérito calcadas em ausência ou insuficiência de provas, desde que observados determinados requisitos e respeitados certos limites, os quais exporemos neste trabalho.

Diante do panorama acima exposto, e partindo das premissas de que (i) o processo deve ser pautado pela instrumentalidade e pelos princípios constitucionais que o regem, para que se possa atingir o objetivo de dar uma resposta justa, eficaz e tempestiva aos jurisdicionados, e (ii) a obtenção dessa tutela jurisdicional justa e efetiva advém da adequação da técnica ao processo e ao procedimento, almeja-se demonstrar que:

(a) a função atualmente conferida à distribuição do ônus da prova, tratando-a apenas como uma regra de julgamento, e os mecanismos estáticos de distribuição do ônus probatório são insuficientes para solucionar satisfatoriamente a complexidade dos conflitos de interesses submetidos ao Poder Judiciário, sobretudo nos conflitos em que há um manifesto desequilíbrio da capacidade probatória das partes; e

(b) o emprego da técnica da distribuição dinâmica do ônus probatório, desenvolvida no âmbito doutrinário, gradativamente aceita pela jurisprudência

12 O termo oposição é aqui empregado no seu sentido literal de contrariedade e não, obviamente, a oposição a que se referem os artigos 56 a 60 do Código de Processo Civil. 
e inserida no Projeto de Lei do novo Código de Processo Civil, como uma forma alternativa (subsidiária) de distribuição do ônus da prova, fundada na análise da capacidade das partes à luz das circunstâncias do caso concreto, permitirá uma otimização da instrução probatória e da descoberta dos fatos, aumentando a possibilidade de se encontrar, em casos específicos e particulares, uma solução conforme o que rege o direito material aplicável à espécie, de modo a melhor atender aos anseios do processo civil moderno.

Para alcançarmos os objetivos propostos, dividimos o estudo em seis capítulos, conforme sumário anteriormente apresentado.

O primeiro capítulo será dedicado, inicialmente, ao exame do que deve ser objeto de cognição pelo magistrado no processo, o qual se encontra, por via de regra, em uma situação de total ignorância em relação aos fatos alegados pelas partes e precisa tentar se convencer sobre as alegações normalmente antagônicas das partes interessadas. Para desenvolver essa cognição, o juiz se utilizará, dentre outros mecanismos, das provas trazidas aos autos pelas partes ou terceiros, e, eventualmente, determinadas de ofício pelo julgador (poderes instrutórios do juiz), as quais têm papel determinante para o desenvolvimento do processo e a concessão da tutela jurisdicional.

Ainda nessas linhas introdutórias, é preciso examinar o duplo enfoque das provas para as partes: como um direito e como um ônus, focando especialmente no primeiro como decorrência das garantias constitucionais do acesso à justiça, ampla defesa, contraditório e efetividade da tutela jurisdicional, haja vista que o segundo será analisado detidamente nos Capítulos seguintes deste trabalho.

O estudo da cognição não ficaria completo sem que fizéssemos menção à fase de valoração da prova, em que o magistrado examina a confiabilidade das informações colhidas, devendo confrontá-las com os limites da verdade, da certeza, da probabilidade ou da verossimilhança, sem prejuízo do risco da dúvida, conforme os parâmetros racionais de convencimento, para que possa, finalmente, dar uma solução ao conflito. Como conclusão deste Capítulo, demonstraremos como o correto desenvolvimento da instrução probatória pode contribuir para a otimização na obtenção da prova e para a adequada formação do 
convencimento do juiz, aproximando-o da realidade do que se passou no caso concreto, de forma a garantir uma tutela jurisdicional mais justa.

No segundo capítulo, adentraremos especificamente no tema do ônus da prova, estabelecendo, em um primeiro momento, uma distinção do ônus em relação às obrigações e aos deveres, para, depois, definirmos mais precisamente o conceito e o alcance do ônus da prova, de maneira a permitir que compreendamos a sua relevância no direito contemporâneo. Em seguida, examinaremos o ônus da prova do ponto de vista da técnica processual e das funções que o ônus da prova tem no processo: atividade-fim (função objetiva) e atividade-meio (função subjetiva), sempre à luz de uma visão instrumentalista, para que, ao final do capítulo, possamos demonstrar que a função subjetiva deve ser sobressalente em um sistema que objetive a melhor obtenção da prova por meio do esforço probatório das partes.

$\mathrm{Na}$ sequência, trataremos da distribuição do ônus da prova, a partir dos fundamentos para sua existência e da relevância da mensuração da capacidade probatória das partes (da plena capacidade de produzir a prova à prova diabólica, passando pelas situações em que há apenas uma dificuldade em produzi-la). O passo seguinte consiste em expor a evolução das técnicas estáticas que procuraram definir a quem incumbe o ônus da prova e os efeitos da não desincumbência, até chegarmos ao modelo atualmente vigente no Código de Processo Civil, sobre o qual procuraremos expor qualidades e deficiências, de modo a evidenciar a necessidade de pensar em outros mecanismos para atuarem paralelamente, como a técnica de distribuição dinâmica do ônus da prova, sempre com o objetivo de incrementar o produto da prova a ser valorada pelo magistrado, aumentando a sua percepção dos fatos para que possa melhor decidir.

Dedicaremos o quarto capítulo ao exame das regras atualmente existentes no Código de Defesa do Consumidor sobre distribuição e "inversão" do ônus da prova, haja vista o seu paralelismo com a técnica da distribuição dinâmica (que ficará evidenciado na exposição do capítulo quinto), apresentando suas características e requisitos, bem como estabelecendo o momento e os limites de sua aplicabilidade.

No quinto capítulo, examinaremos o tema central do presente trabalho, a técnica da distribuição dinâmica do ônus da prova, no qual faremos inicialmente uma 
análise dogmática do instituto, a partir do estabelecimento dos seus pressupostos axiológicos, da definição das suas características essenciais e dos requisitos condicionantes à sua aplicabilidade, bem como do momento adequado de incidência da técnica dinâmica, para que, enfim, possamos formular uma regra geral de aplicabilidade dessa técnica.

Fixados os aspectos essenciais da técnica de distribuição dinâmica do ônus da prova, abordaremos os motivos que autorizam a aplicação dessa técnica à luz do Código de Processo Civil de 1973, independentemente de previsão expressa que a regule, em face dos princípios norteadores do processo civil moderno, bem como as críticas existentes a respeito da tentativa de implementação da referida técnica sem uma norma autorizadora.

Ainda sobre o tema, em face da previsão da técnica da distribuição dinâmica do ônus da prova no projeto do novo Código de Processo Civil, faremos uma análise da proposta legislativa atualmente existente, destacando os pontos positivos e negativos da redação projetada, e procurando apontar os possíveis ajustes que poderiam ser realizados para aprimorar o futuro emprego dessa técnica no direito brasileiro, a partir de previsão legislativa expressa.

Em seguida, confrontaremos a técnica de dinamização com a regra prevista no Código de Defesa do Consumidor, com o intuito de demonstrar que são a mesma técnica, aplicada sob pontos de vista distintos.

Para fechar, compatibilizaremos a técnica da distribuição dinâmica com os poderes instrutórios do juiz, que, como veremos, não são excludentes entre si, e, desde que seja observado o dever de imparcialidade do julgador, esses instrumentos podem ter uma importante função de incrementar o arcabouço probatório, ampliando a cognição e aperfeiçoando o julgamento.

Não obstante toda a exposição dogmática, o presente trabalho não ficaria completo se nos restringíssemos a examinar a técnica de distribuição dinâmica do ônus da prova apenas do ponto de vista expositivo, afinal, como técnica de potencialização da descoberta dos fatos, é imprescindível analisar a sua incidência prática, por intermédio da sua conciliação com outros mecanismos de flexibilização do ônus probatório e com os meios de prova atualmente existentes. 
Dessa forma, no sexto capítulo, examinaremos o posicionamento da jurisprudência a respeito do tema e confrontaremos a técnica de distribuição dinâmica do ônus da prova com os mecanismos atualmente existentes de flexibilização do ônus da prova, em especial as hipóteses de presunção e de distribuição convencional do ônus da prova.

Depois, faremos uma verificação: em quais meios de prova podemos vislumbrar uma efetiva incidência prática da técnica de distribuição dinâmica dos ônus probatórios, de modo a nos permitir delimitar o real campo de aplicação da aludida técnica no processo civil?

Para concluir esse sexto capítulo, faremos uma confrontação da técnica de distribuição dinâmica das cargas probatórias com os mecanismos de valoração da prova, denominados "modelos de constatação" (ou "standards probatórios"), com o objetivo de evidenciar que, embora todos sejam mecanismos que visem fim comum (a facilitação do acesso à tutela jurisdicional àqueles que se encontrem em uma situação de maior dificuldade em fazer a comprovação dos fatos que fundamentam as suas pretensões em juízo), estas são técnicas processuais com aplicação em momentos completamente distintos, pois, enquanto a dinamização da distribuição do ônus da prova deve ocorrer no curso da instrução probatória ou ao final, caso permaneça o estado de dúvida do julgador, os "modelos de constatação" e eventual "redução do módulo da prova" (diminuição do grau de exigência de confirmação da prova) são percebidos no momento de valoração da prova e formação do convencimento pelo julgador.

As conclusões extraídas do presente estudo serão sintetizadas no tópico final do trabalho, sem prejuízo daquelas que forem exaradas ao longo da dissertação. 


\section{CAPÍTULO 1 \\ COGNIÇÃO, PROVA E TUTELA JURISDICIONAL}

Objeto da cognição e finalidade da prova ${ }^{13}$

Todo direito origina-se de um fato (ex facto oritur jus) e o juiz, ao se deparar com uma demanda, encontra-se, por via de regra, ${ }^{14}$ em um estado de ignorância em relação aos fatos que fundamentam as pretensões das partes.

Somente com o exercício da cognição, que em um processo ideal seria plena (no plano horizontal) e exauriente (no plano vertical), ${ }^{15}$ decorrente de uma instrução probatória bem aparelhada, é que o magistrado poderá atingir um maior grau de certeza quanto ao que efetivamente se passou e, assim, formar sua convicção sobre o direito controvertido e decidir a lide a favor de quem efetivamente faz jus à tutela jurisdicional. ${ }^{16}$

O objeto da investigação judicial, segundo ensina KAZUO WATANABE, está calcado em um trinômio, qual seja: os pressupostos processuais, as condições da ação e o mérito. ${ }^{17}$ Em qualquer uma das bases desse trinômio o juiz pode se deparar com alegações de fatos que precisarão ser adequadamente investigados para que possa formar o seu

13 O termo "prova", no processo, tem múltiplos significados, podendo ser empregado para designar os meios de afirmar a verdade das alegações (actus probandi), a ação de fazer prova, os meios de prova (testemunha, documento etc.) ou ainda o resultado dos atos produzidos na apuração da verdade (AMARAL SANTOS, Moacyr. Prova judiciária no cível e comercial. 3. ed. São Paulo: Max Limonad, 1961. v. 1, p. 11-12). Aqui, o seu emprego também é plurissemântico.

Para alguns autores, esse estado de desconhecimento dos fatos pelo juiz é inexorável. Segundo Nicola Framarino Dei MALATESTA, "antes de o espírito humano se encontrar, relativamente ao conhecimento de um fato, no estado de dúvida, ou de probabilidade, ou de certeza; antes de percorrer esta escala ascendente psicológica que conduz à posse luminosa da verdade, pode o espírito humano achar-se naquele estado negativo e tenebroso que se denomina ignorância" (A lógica das provas em matéria criminal. Tradução A. A. Correia. São Paulo: Saraiva, 1960. v. 1, p. 136).

Em tal circunstância, o procedimento seria "plenário quanto à extensão do debate das partes e da cognição do juiz, e completo quanto à profundidade dessa cognição" (WATANABE, Kazuo. Da cognição no processo civil. 4. ed. São Paulo: Saraiva, 2012. p. 120; grifos do autor).

16 Por certo, existem situações da vida que exigem outras configurações do grau de amplitude e profundidade da cognição judicial para a obtenção de uma tutela jurisdicional justa e efetiva, como as medidas cautelares, liminares, entre outras, mas o grau de certeza exigido em tais circunstâncias também será diferenciado. $\mathrm{O}$ enfoque do presente trabalho não permite um maior aprofundamento sobre o tema, e, diante dos objetivos anteriormente traçados, nos concentraremos no ideal de cognição pretendido para as ações de conhecimento para tutela de interesses individuais. 
convencimento. Para os propósitos do presente trabalho, contudo, nos fixaremos no estudo da cognição desenvolvida apenas para o exame do mérito da causa. ${ }^{18}$

Existem duas ordens de questões a serem objeto da cognição: as questões de fato e as questões de direito. As questões de fato concentram todas as controvérsias sobre as alegações fáticas formuladas pelas partes e que sustentam as suas respectivas pretensões. As questões de direito, por sua vez, envolvem os conflitos de normas jurídicas in abstrato e os efeitos incidentes para o caso concreto.

Com o encerramento da fase postulatória, na qual as partes instauram o contraditório, formulam ao juízo as suas pretensões e se opõem às pretensões da parte contrária, se desincumbido (ou não) dos respectivos ônus de afirmação, ${ }^{19}$ resta delimitado o objeto da cognição judicial.

A par da quantidade de controvérsias fáticas formuladas em determinada demanda, nem todas as questões de fato deverão ser objeto de prova, ${ }^{20}$ sendo função do magistrado, antes do início da fase instrutória, a delimitação das questões de fato que efetivamente necessitam ser provadas, inclusive com a atribuição dos respectivos ônus probatórios às partes.

Assim, o momento adequado para o magistrado fixar as alegações de fato que deverão ser submetidas à prova é no denominado "despacho saneador", ${ }^{21}$ oportunidade em

18 O mérito da causa, para efeitos de cognição, deve ser interpretado de forma ampla, abrangendo tanto o objeto litigioso quanto as demais questões de mérito suscitadas pelas partes e/ou cognoscíveis de ofício, as quais precisam ser conhecidas (mesmo que incontroversas) e resolvidas (para eliminação da dúvida sobre os pontos controvertidos) antes da tomada de decisão sobre o thema decidendum, servindo-lhe de fundamento (WATANABE, Kazuo. Da cognição..., cit., p. 113). Para DinAmARCO, o conceito de mérito é muito mais restrito, limitando-se à pretensão processual da parte, que pode ter dupla direção: pedido imediato (provimento jurisdicional) e pedido mediato (bem da vida), constituindo o "elemento substancial da demanda, o seu conteúdo socialmente relevante", sobre o qual o juiz deve se pronunciar no dispositivo da sentença (Fundamentos..., cit., p. 202-203).

Para DiNAMARCO, "o ônus de afirmar antecede o de provar, uma vez que o objeto do conhecimento do juiz é composto pelas afirmações das partes e, sem que haja estas, não haveria sequer o que provar”. (Instituições de direito processual civil. 2. ed. São Paulo: Malheiros, 2002, v. 2, p. 252).

20 Como lembra JOÃo BATISTA LOPES, não se trata de provar quaisquer alegações de fato. O objeto da prova são as alegações de fatos "relevantes, pertinentes, controversos e precisos" (A prova no direito processual civil. 2. ed. São Paulo: RT, 2002. p. 32). O artigo 334 do Código de Processo Civil relaciona os fatos que "não dependem de prova".

21 Com efeito, determina o $\S 2 .^{\circ}$ do artigo 331 do Código de Processo Civil que, caso não obtida a conciliação na audiência preliminar, em despacho saneador “o juiz fixará os pontos controvertidos, decidirá as questões processuais pendentes e determinará as provas a serem produzidas, designando 
deverão ser sanadas eventuais irregularidades processuais, examida a presença dos pressupostos processuais e das condições da ação, para que o processo possa ter o seu regular prosseguimento ${ }^{22}$.

Diante das postulações das partes, que deverão envolver alegações de fato e de direito, o juiz depara-se com pontos do autor e pontos do réu. Quando os pontos de fato são convergentes, a alegação se torna incontroversa, ficando dispensada de prova, conforme inciso III do artigo 334 do Código de Processo Civil. ${ }^{23}$

A prova ganha especial relevância quando os pontos de fato alegados pelo autor e pelo réu são divergentes, de modo que tais pontos se tornam "questões de fato", as quais necessitam ser solucionadas pelo magistrado, com base na convicção que adquirir em decorrência da valoração das provas produzidas.

Com a definição das questões de fato que dependem de prova para serem consideradas pelo juiz no momento da valoração, também deve o juiz, em observância à necessidade de diálogo constante com as partes, requisito indispensável para um processo justo, estabelecer no "despacho saneador" quais os ônus probatórios de cada uma das

audiência de instrução e julgamento, se necessário". GALENO LACERDA, criticando a inclusão dos atos relativos à prova no despacho saneador (embora concorde com o momento de fazê-lo), prescreve que "sanear a prova significa delimitar-lhe o objeto [...] com a finalidade de preparar a audiência principal, [...] com o fim de circunscrever não a prova, mas a discussão das questões controvertidas. Esta, sim, merece policiamento que proíba divagações inúteis e fastidiosas" (Despacho saneador. Porto Alegre: Livraria Sulina, 1953. p. 94 e 98).

A prática forense, contudo, revela que nem todos os juízes têm essa preocupação com o saneamento, sobretudo para fins de atribuição dos respectivos ônus probatórios às partes, quando se trata de aplicação da regra geral e abstrata de distribuição do ônus da prova estabelecida no Código de Processo Civil, o que dispensaria sua repetição no despacho saneador, porquanto de conhecimento das partes (ou ao mesnos de seus respectivos advogados). Esta postura, condenável do ponto de vista de organização da prova em um modelo participativo de processo, não parece sofrer qualquer tipo de efeito negativo, porquanto, como afirma o DINAMARCO, não passa de uma advertência, sem cunho decisório (Instituições de direito processual civil. 2. ed. São Paulo: Malheiros, 2002. v. 3, p. 83). Talvez essa "leniência" dos juízes sofra mudanças com a promulgação do novo Código de Processo Civil, cujo artigo 354, ao tratar da "decisão de saneamento e de organização do processo", determina expressamente que cumpre o magistrado "definir a distribuição do ônus da prova, observado o art. 370" (inciso III). Disponível em: <http://www.senado.gov.br/atividade/materia/getPDF.asp ?t=157884\&tp=1 > . Acesso em: 10 dez.2014.

23 Sem prejuízo da submissão da veracidade do fato inconstroverso à racionalidade do julgador. Como adverte MiCHELE TARUFFO, “[...] o fato não contestado deve ser efetivamente objeto de decisão, no sentido de que o juiz pode sempre retirar elementos de convencimento sobre a veracidade ou a falsidade ddesse a partir de qualquer fonte de informação que lhe eseja franqueada no curso do processo. Além disso, o juiz poderá desconhecer sua existência, por exemplo, quando a veracidade daquele fato lhe parecer inverossímil, ou resultar estar em contraste com outros fatos provados". (Uma simples verdade: o juiz e a construção dos fatos. Tradução V. P. Ramos. São Paulo: Marcial Pons Brasil, 2012. p. 158). 
partes, advertindo-as sobre os riscos da não desincumbência, para que as partes possam desempenhar adequadamente as providências de produção das provas que lhes cabem. ${ }^{24}$

Conhecedores dos seus respectivos ônus, as partes podem adotar uma postura ativa ou passiva diante das provas que lhes incumbem, assumindo os riscos da sucumbência na hipótese de as questões de fato que lhe competiam provar não restarem comprovadas ou forem insuficientemente demonstradas. De qualquer forma, com a fixação das questões de fato e de direito no despacho saneador e a (eventual) atribuição dos respectivos ônus da prova às partes, o juiz cumpre o dever de oportunizar a ampla defesa e o contraditório, os quais deverão se desenvolver também na fase instrutória, com a realização das provas das questões de fato anteriormente fixadas.

Superada a fase instrutória, com base nas provas colhidas, o magistrado procura fazer uma reconstrução histórica dos fatos relevantes para o julgamento da causa, com o objetivo de formar o seu convencimento sobre a veracidade das alegações ${ }^{25}$. Em seguida, convicto da realidade fática envolvida, ele faz a valoração jurídica dos fatos e as suas consequências para o caso concreto (subsunção do fato à norma), aplicando, in concreto, a regra legal pertinente e dando a solução ao litígio. ${ }^{26}$

Esse iter da atividade cognitiva, contudo, não se desenvolve de forma tão linear quanto descrito. De fato, o julgador está sujeito a uma infinidade de influências externas e internas ao processo, que vão desde suas ideologias, princípios, valores, convicções religiosas, até as condutas assumidas pelas partes, pelas testemunhas e terceiros.

24 Nas palavras de DINAMARCO, "é dever do juiz, na audiência preliminar (art. 331), informar as partes do ônus que cada uma tem e adverti-las da consequência de eventual omissão - porque uma das tarefas a realizar nessa oportunidade é a organização da prova mediante fixação dos limites do seu objeto e determinação dos meios probatórios a desencadear” (Instituições..., cit., v. 3, p. 83).

Como sustenta ENRICO TULlio LIEBMAN, o conhecimento do juiz a respeito da verificação dos fatos "tem caráter histórico, porque seu escopo é descobrir a verdade relativamente às circunstâncias de fatos relevantes para a causa [...]" (Manual de direito processual civil. Tradução C. R. Dinamarco. Rio de Janeiro: Forense, 1984. v. 1, p. 165). Em outra oportunidade, o autor reforça que "o processo de cognição é dirigido à formação de um juízo e que este consiste na valoração do ponto de vista do direito, de um fato ou de um grupo de fatos. Mas os fatos, antes de avaliados, devem ser declarados certos, em sua existência material”. Manual de direito processual civil. Tocantins: Intelectus, 2003. v. 2, p. 79-80).

26 Os efeitos da não formação da convicção do magistrado ou sua insuficiência, sempre possíveis de ocorrer, mesmo quando desenvolvida uma cognição plena e exauriente, serão estudados no item "2.3.2", a seguir. 
Malgrado tais influências, o juiz não se encontra totalmente livre para julgar conforme bem lhe aprouver, encontrando-se vinculado às regras da racionalidade, que lhe permitem chegar a uma conclusão lógica e justificável, bem como tem o dever de motivar as escolhas que faz, de modo a permitir o seu controle externo (princípio do livre convencimento motivado).

De qualquer forma, diante da ignorância natural do magistrado acerca das alegações de fato (controvertidas ou não), é essencial que lhe sejam trazidos elementos de prova capazes de elucidar e comprovar as alegações formuladas pelas partes, sobretudo diante a contrariedade instaurada pelas partes.

A adequada colheita das provas tem, assim, papel essencial na formação do convencimento no espírito do julgador sobre a veracidade das alegações de fato $^{27}$ formuladas pelas partes e, consequentemente, para a concessão de uma tutela jurisdicional efetiva e justa. $^{28}$

Ocorre que em inúmeras oportunidades a prova não é adequadamente produzida e a convicção do magistrado fica comprometida. Para que a cognição seja realmente plena e exauriente, e, dessa forma, a tutela jurisdicional a ser concedida ao final do processo seja efetiva e justa, o julgador deve se valer de técnicas que permitam a adequada colheita do material probatório para a formação do seu convencimento, antes de se conformar com um julgamento calcado exclusivamente na regra de distribuição do ônus da prova.

A maneira mais comum de as provas serem produzidas se dá por meio das partes interessadas, que sabem (ou ao menos seus advogados deveriam saber) que, se não fornecerem ao juiz os elementos de prova que confirmam as suas alegações de fato, correm o risco de sucumbir, o que, como vimos, pode ser reforçado no despacho saneador ou mesmo em outras oportunidades de diálogo entre o juiz e as partes.

27 AMARAL SANTOS, Moacyr. Prova..., cit., v. 1, p. 15.

28 Nas palavras de LIEBMAN, "se a justiça é o fim último da jurisdição, a prova é um instrumento essencial, porque não pode haver justiça senão fundada na verdade dos fatos a que se refere" (Manual..., cit., v. 2, p. 80). 
Mesmo diante desse fim indesejável, existem situações em que a capacidade probatória $^{29}$ de determinada parte está tão comprometida que, mesmo se quisesse se desincumbir do seu ônus, tal providência seria inócua. ${ }^{30}$ Para essas circunstâncias, o sistema deve ser dotado de mecanismos de reequilíbrio, como a distribuição dinâmica do ônus da prova, com o deslocamento do ônus de uma parte à outra, com o respectivo deslocamento do objeto da prova, de maneira que a instrução possa ser a mais completa possível e a apuração dos fatos a mais próxima da realidade.

Entretanto, não é apenas pelas partes que a atividade probatória pode ser produzida. $\mathrm{Na}$ atual perspectiva do processo como instrumento de satisfação de interesses sociais e políticos (além do jurídico, obviamente), o juiz deixou de ser mero expectador para se tornar um dos protagonistas do processo.

Ainda que com algumas restrições, como veremos a seguir, o juiz é atualmente dotado de amplos poderes instrutórios, que lhe permitem adotar providências para esclarecimento dos fatos relevantes da causa para formação do seu convencimento e o julgamento final. Esse é outro relevante instrumento processual para assegurar a concessão da tutela jurisdicional de forma efetiva e justa, porquanto calcado em uma investigação plena e exauriente dos fatos, como veremos a seguir.

Portanto, para que a cognição possa se desenvolver em sua plenitude no processo, em ambos os planos, de forma a assegurar a adequada apuração das questões de fato pertinentes ao caso concreto, e, desse modo, permitir a correta formação da convicção do magistrado sobre os fatos e o direito controvertidos, o magistrado deve ter uma condução ativa da instrução desde sua preparação, com a fixação das questões de fato objeto da prova e dos respectivos ônus probatórios das partes e, durante o seu desenvolvimento, seja utilizando a técnica da distribuição dinâmica do ônus da prova (objeto central do presente estudo), seja exercendo seus poderes instrutórios. ${ }^{31}$

29 A capacidade probatória consiste na possibilidade (ou não) de se realizar a prova da alegação de fato, a ser apurada e mensurada à luz dos meios probatórios e dos conhecimentos que a parte tem sobre a alegação e fato objeto da prova. No item “3.2” do Capítulo 3 trataremos sobre esse tema. As causas de redução ou inexistência da capacidade probatória são inúmeras, podendo decorrer de fatores técnicos, culturais, econômicos, jurídicos ou mesmo físicos, por exemplo, no caso de detenção das fontes de prova por apenas uma das partes ou terceiros desconhecidos da parte onerada.

31 Em relação aos poderes instrutórios, trataremos brevemente no item seguinte e, posteriormente, no Capítulo final, para confrontar a sua aplicação prática com a técnica da distribuição dinâmica do ônus da prova. 


\subsection{Prova, partes e poderes instrutórios do juiz}

A produção da prova sobre as alegações de fato é, em regra, ônus das partes que as formulam, pois as próprias partes são as maiores interessadas em ter suas alegações acolhidas.

Como sustenta MiChELE TARUFFO, as alegações das partes, expostas nas narrativas dos seus respectivos advogados, têm uma "pretensão de veracidade", ${ }^{32}$ mas não passam de enunciados apofânticos, ou seja, que podem ser verdadeiros ou falsos, de modo que apenas a devida instrução probatória poderá ensejar a demonstração da verdade das alegações e, assim, o juiz formar o seu convencimento.

O interesse das partes, contudo, refere-se ao resultado do processo, e não necessariamente à verdade. Elas têm o ônus de provar que suas alegações de fato têm fundamento, e não necessariamente que são verdadeiras. ${ }^{33}$

Diante dessa atuação parcial das partes, o magistrado não pode figurar no processo como um mero direcionador da prova a esta ou àquela parte, sendo cada vez mais presente a figura do juiz investigador, que determina a produção de provas de ofício para dirimir suas dúvidas sobre a construção dos fatos. ${ }^{34}$

A partir dos estudos desenvolvidos a partir do final do século XIX na Europa continental e posteriormente nos países latino-americanos, ficou evidenciado que, à luz de uma visão social do processo, o juiz deveria abandonar sua postura passiva e passar a agir

$32 \quad$ Uma simples verdade..., cit., p. 67-68.

33 Daí por que TARUFFO defende que as partes não exercem uma função epistemológica pura, pois suas iniciativas e atividades não são direcionadas necessariamente no sentido da busca e da descoberta da verdade (Uma simples verdade..., cit., p. 196-197).

BARBOSA MOREIRA, já nos idos de 1985, advertia que o juiz "já não se pode comportar no arquétipo do observador distante e impassível da luta entre as partes, simples fiscal incumbido de vigiar-lhes o comportamento, para assegurar a observância das 'regras do jogo' e, no fim, proclamar o vencedor. [...] Os poderes instrutórios, a bem dizer, devem reputar-se inerentes à função do órgão judicial, que, ao exercê-los, não se 'substitui' às partes, como leva a supor uma visão distorcida do fenômeno. Mas é inquestionável que o uso hábil e diligente de tais poderes, na medida em que logre iluminar aspectos da situação fática, até então deixados na sombra por deficiência da atuação deste ou daquele litigante, contribui, do ponto de vista prático, para suprir inferioridades ligadas à carência de recursos e de informações, ou à dificuldade de obter o patrocínio de advogados mais capazes e experientes. Ressalta, com isso, a importância social do ponto" (A função social do processo civil moderno e o papel do juiz e das partes na direção e na instrução do processo. Revista de Processo, São Paulo: RT, v. 10 , n. 37 , p. $146-147$, jan. 1985). 
mais contundentemente na condução do processo, de forma a atender não apenas o interesse das partes litigantes, mas de toda a sociedade. ${ }^{35}$

O compromisso do juiz é com a justiça e a verdade. Para que tais valores sejam atingidos é essencial que ele tenha liberdade para desenvolver atividades probatórias para o melhor esclarecimento dos fatos e decidir conforme seu livre convencimento motivado.

Nessa perspectiva, o processo deixou de ser "coisa das partes", e a instrução probatória, assim como a descoberta da verdade, da mesma forma, deixam de estar restritas às vontades exclusivas das partes interessadas, cabendo também ao magistrado desenvolver ex officio a atividade de cognição dos fatos relevantes, o que se denominou "poderes instrutórios do juiz". 36

A doutrina pátria tem gradativamente acolhido os poderes instrutórios do juiz para determinar a realização de ofício de provas que entende pertinentes ao esclarecimento dos fatos, variando, contudo, as funções por eles exercidas em relação aos ônus probatórios das partes e sua intensidade. ${ }^{37}$

Em relação às funções pertinentes aos poderes instrutórios, podemos distinguir três espécies: função concorrente, função substitutiva ou função subsidiária.

Para os defensores da função concorrente dos poderes instrutórios, coincidente com sua maior intensidade, o juiz deve preocupar-se em dar a melhor solução ao litígio, sem qualquer preocupação com as pretensões das partes, buscando diligenciar no sentido

35 Ao se indagar "a quem interessa um Processo Civil?", BARBOSA MOREIRA demonstra que o pensamento antigo de que haveria interesse apenas das partes é uma "meia verdade", porquanto "a rigor, não há processo que interesse exclusivamente às partes e não ecoe na paisagem da sociedade", sobretudo porque "o processo é instrumento da jurisdição, e portanto exercício do poder estatal", sendo interesse da sociedade que "o feito se realize com o dispêndio necessário e suficiente de tempo e de energias: nem menos, nem mais. É uma imposição que pode coincidir ou não com o desejo dos litigantes [...]" (O processo, as partes e a sociedade. Revista de Processo, São Paulo: RT, v. 30, n. 125, p. 279-288, jul. 2005).

Dados os restritos limites do objeto da investigação, não nos aprofundaremos sobre o estudo dos poderes instrutórios do juiz, seus requisitos e limites, mas o tema voltará a ser objeto do nosso estudo no item "5.10" do Capítulo 5.

Para os fins do presente estudo, cumpre-nos examinar em que medida o incremento dos poderes instrutórios do juiz afeta a distribuição do ônus da prova entre as partes, pois não vislumbramos a sua completa supressão em face dos poderes instrutórios, em especial quando pertinente à distribuição dinâmica. 
de obter os esclarecimentos pertinentes para dar uma resposta conforme o direito, além de, assim, ver atendido o escopo social da jurisdição. ${ }^{38}$

Em uma linha intermediária, aceitando uma função substitutiva para os poderes instrutórios, alguns autores sustentam que em determinadas situações excepcionais, como medida de preservação da "igualdade entre os litigantes", da "dignidade da jurisdição" e da “indisponibilidade dos direitos e relações jurídico-substanciais em certos casos”, o juiz deve valer-se dos seus poderes instrutórios, em substituição às partes, para suprimir, como iniciativas próprias, as "deficiências probatórias das partes". 39

Já a terceira linha de pensamento, mais restritiva, enxerga nos poderes instrutórios uma função apenas subsidiária, que seriam utilizados de forma supletiva às provas realizadas pelas partes se, e apenas se, o material probatório se mostrasse insuficiente para formação do seu convencimento. ${ }^{40}$

De qualquer forma, se, por um lado, o uso dos poderes instrutórios pelo magistrado pode contribuir para a obtenção da prova e da verdade, por outro lado, ao assim agir fica reduzida a relevância do emprego da técnica de distribuição do ônus probatório às partes (mais se admitida a função concorrente e menos nafunção subsidiária), seja de forma estática ou dinâmica, ao menos como mecanismo de estruturação da prova e colaboração das partes, pois, como regra de julgamento, a técnica de distribuição do ônus da prova é

38 Entre os defensores dessa corrente encontramos BEDAQUE (Poderes instrutórios do juiz. 5. ed. São Paulo: RT, 2011. p. 115 e ss), ANTONIO JANYR DALL'AgnOL JUNIOR (Comentários ao Código de Processo Civil. São Paulo: Revista dos Tribunais, 2000. v. 2, p. 132-133), SIDNEY DA SILVA BRAGA (Iniciativa probatória do juiz no processo civil. São Paulo: Saraiva, 2004. p. 130-131) e DANIEL PENTEADO DE CASTRO, para quem "[...] a iniciativa probatória do magistrado não se limita ao momento posterior às provas produzidas pelas partes nos autos, mas pode o juiz exercer essa iniciativa na mesma ocasião em que decide sobre a produção de provas [...]”. (Poderes instrutórios do juiz no processo civil: fundamentos, interpretação e dinâmica. São Paulo: Saraiva, 2013. p. 189). Esse posicionamento é adotado por DINAMARCO (Instituições..., cit., v. 3, p. 51-56).

40 Adotando essa forma de pensar, temos JoÃo BATISTA LOPES (A prova..., cit., p. 199), embora reconheça sua valia no atual estágio de evolução do processo civil. No mesmo sentido, HUMBETO THEODORO JÚNIOR, para o qual os poderes instrutórios "trata $(m)$-se de atividade integrativa e supletória (das partes), de modo que, quando estas exercitam seus poderes para produzir todas as provas disponíveis, e o munem dos elementos suficientes para a comprovação dos fatos relevantes da causa, não há nenhuma necessidade de que o magistrado utilize seus poderes instrutórios. Cabe, contudo, ao juiz, usar dos poderes de iniciativa, na espécie, sempre que algum meio de prova a seu alcance possa ser empregado para o melhor conhecimento dos fatos fundamentais do conflito, mesmo que os litigantes não o requeiram. Nesse passo, seu compromisso não é com a posição de nenhuma das partes, mas com a verdade, sem a qual não se consegue fazer a justiça, para cuja realização se idealizou a tutela jurisdicional no Estado Democratico de Direito". (Curso de direito processual civil. 51. ed. Rio de Janeiro: Forense, 2010. v. 1, p. 429). 
inafastável, podendo a atividade instrutória do juiz restar infrutífera ou insuficiente para afastar o estado de dúvida ${ }^{41}$.

Voltaremos ao tema quando tratarmos da aplicação da técnica de distribuição dinâmica do ônus da prova na prática forense, oportunidade em que dedicaremos um item específico à confrontação da técnica dinâmica com os poderes instrutórios do juiz e os limites de sua imparcialidade quando essa atuação de ofício beneficia a parte hipossuficiente em relação à capacidade de produzir a prova.

Em relação à intensidade dos poderes instrutórios do juiz, trata-se de aspecto primordial a ser examinado, sobretudo à luz da disponibilidade do direito comumente utilizado para tolher os poderes instrutórios do juiz.

Para a correta compreensão do tema, é preciso, entretanto, tecer algumas considerações sobre o princípio dispositivo, em especial no que concerne à disponibilidade da prova e do direito material.

A doutrina não tem um consenso sobre a abrangência do princípio dispositivo, ora restringindo-o ao direito material, como BARBOSA MOREIRA ${ }^{42}$ e BEDAQUE, ${ }^{43}$ ora ampliando-o também para os ônus processuais, como, na doutrina estrangeira, MAURO CAPPELletTI $^{44}$ e, na doutrina nacional, Heitor SICA, ${ }^{45}$ ora confundido e abrangendo o princípio da demanda, como DANIEL PENTEADO DE CASTRO. ${ }^{46}$

Trataremos sobre as funções do ônus da prova no item "2.3" e subtitens do Capítulo 2.

Para o professor fluminense, tornou-se "natural" a correlação entre a disponibilidade do direito material e o princípio dispositivo aplicado no direito processual, de modo que "o que é disponível fora do processo continua a sê-lo no processo", e que "a observação da realidade, entretanto, não confirma a expectativa", pois não é a "disponibilidade" do direito que define o limite de atuação do juiz, de modo que "se a ideia da disponibilidade da relação jurídica material, como ficou demonstrado, não se presta a ministrar a razão suficiente das várias limitações impostas à iniciativa do juiz, será aconselhável continuar a usar, e com alcance genérico, uma expressão - princípio dispositivo - tão propícia a evocar aquela ideia e, por conseguinte, a pôr em falsa pista quem quer que a leia ou a ouça com mente aberta às sugestões da etimologia?", e responde que somente poderia ser assim denominado os "atos de disposição que as partes pratiquem no curso do processo" (O problema da "divisão do trabalho" entre juiz e partes: aspectos terminológicos. Temas de direito processual: quarta série. São Paulo: Saraiva, 1989. p. 36, 42 e 43).

43 Poderes..., cit., p. 98-104.

44 El testimonio de la parte en el sistema de la oralidad: contribución a la teoría de la utilización probatoria del saber de las partes en el proceso civil. Tradução S. S. Melendo. La Plata: Platense, 2002. v. 1, p. 291 e ss. 
Contudo, a essência que o define é a disponibilidade das partes em relação a um direito (material ou processual), sobre a qual o juiz não tem qualquer influência.

Quando enfocado sob o aspecto da instrução probatória, o princípio dispositivo costuma ser contraposto ao princípio inquisitivo, como se fosse possível distinguir em dois sistemas de apuração dos fatos que, em verdade, não se excluem, mas se complementam, sendo recorrente a referência a sistemas mistos, ${ }^{47}$ como o nosso, em que as partes estão imbuídas do ônus de produzir provas e, em paralelo, o juiz também é dotado de poderes instrutórios para a apuração da realidade fática envolvida em determinada demanda, sempre que observados os limites de sua atuação. ${ }^{48}$

Assim, em regra, o juiz não está adstrito às provas requeridas pelas partes para comprovação das questões de fato, podendo indeferir aquelas que se mostrarem impertinentes ou inviáveis e ordenar a realização de outras que julgue convenientes para um melhor aparelhamento do arcabouço probatório, o qual será por ele utilizado para formação do seu convencimento.

Em relação às provas, portanto, a disponibilidade das partes fica relativizada diante da possibilidade do desenvolvimento ex officio das provas pelo juiz.

47 Analisando as funções epistêmicas das atuações das partes e do juiz, TARUFFO ressalta a inexistência de conflito entre ambas, apontando que a melhor solução seria mesmo a sua conjugação, "no sentido de garantir a mais completa e racional obtenção dos dados cognoscitivos necessários para a apuração da verdade. Os poderes instrutórios das partes e os do juiz não faz parte de um unicum em que, se os primeiros são aumentados, os últimos são limitados, ou vice-versa, como se o aumento dos poderes instrutórios do juiz implicasse uma limitação dos direitos das partes. Pelo contrário: trata-se de instrumentos diferentes que podem ser ativados por sujeitos diferentes, que podem muito bem ser utilizados contemporaneamente com o fim de maximizar a obtenção dos dados probatórios necessários para a decisão" (Uma simples verdade..., cit., p. 206). E, como ressalta GALENO LACERDA, "jamais poderá o juiz substituir-se à parte, no afã de demonstrar a verdade de suas pretensões, e é, precisamente, desse contraditório amplo, que brotam argumentos e fatos de excepcional importância para a decisão, de outra forma despercebidos ao julgador". E conclui, "tempere-se essa liberdade (das partes) com uma sadia faculdade inquisitória complementar do juiz - e ter-se-á, sem dúvida, maior segurança na decisão" (Despacho..., cit., p. 97). No mesmo sentido é o posicionamento de BARBOSA MOREIRA, para quem nenhum processo é absolutamente dispositivo, uma vez que sempre haverá alguma característica que o aproxima do processo dispositivo, assim como nenhum processo é totalmente inquisitivo (Reformas processuais e poderes do juiz. Temas de direito processual civil: nona série. São Paulo: Saraiva, 2004. p. 53).

Os limites comumente aceitos aos poderes instrutórios, segundo LEO ROSENBERG, são quatro: (i) a pertinência temática da prova a ser produzida (relacionada ao pedido e à causa de pedir, para observância do princípio da congruência entre pedido e sentença); (ii) a motivação (para possibilidade do controle extenso); (iii) a observância do contraditório e da ampla defesa (para atendimento a garantia constitucional); e (iv) a vedação de provas ilícitas, além dos limites naturais, como a falta de antecipação dos honorários periciais pelas partes ou negativa dos órgãos oficiais de realizar a prova (La carga de la prueba. Tradução E. Krotoschin. 2. ed. Buenos Aires: B de F, 2002. p. 88). 
Esse ativismo judicial, contudo, será tanto mais intenso quanto maior a indisponibilidade do direito material objeto do litígio ou, a contrario sensu, seja mais reduzido quanto maior a disponibilidade do direito material.

Com efeito, embora a disponibilidade não seja uma limitação legal aos poderes instrutórios do juiz, é inconteste que a maior disponibilidade das partes em relação ao objeto litigioso irá exigir do juiz menor ingerência no processo e na instrução probatória, sem que isso lhe retire o dever de apurar a verdade dos fatos para melhor julgar.

Essa constatação é feita por BEDAQUE, o qual, embora sustente uma indiferença do direito material litigioso para o exercício dos poderes instrutórios, reconhece que "é óbvio que o juiz se sentirá condicionado psicologicamente a atuar com maior intensidade se indisponível o objeto do processo. Essa influência subjetiva não pode ser negada". ${ }^{4}$

No mesmo sentido, José CARLO BAPTISTA PuOLI sustenta que haveria mesmo uma necessidade/dever de variação dos poderes instrutórios de acordo com a disponibilidade do direito objeto da demanda, advertindo que, dessa forma, se

[...] atende à própria realidade do cotidiano forense, de forma, que, não sendo possível fechar os olhos à situação fática, não se pode querer que em todos os casos tenha o juiz o mesmo grau de participação, estudo e aplicação. Exigir isto seria utópico e corresponderia a contribuir para uma elevação no tempo de processamento das demandas, o que é, também, inadmissível. ${ }^{50}$

Diante do exposto, em nosso sentir, é evidente que a condução da instrução probatória deve ser sempre pautada pela descoberta da verdade (ou o mais próximo possível da verdade), para que a decisão a ser proferida reflita a realidade e conceda a tutela jurisdicional de forma justa, mas nunca sem perder de vista a necessidade de se proferir um juízo de certeza em tempo compatível e que permita um resultado útil à parte titular do direito material tutelado. ${ }^{51}$

50 Os poderes do juiz e as reformas da lei processual civil brasileira. São Paulo: Juarez de Oliveira, 2002. p. 27.

51 Como observa LIEBMAN, uma das finalidades da correta estruturação da prova é "proporcionar tanto quanto possível a descoberta da verdade; mas esse objetivo deve se conciliar com a necessidade de agilizar a decisão da causa e favorecer assim a certeza das relações jurídicas, e isto é obtido mediante a aplicação de algumas regras fixas extraídas da experiência geral da vida. O efeito geral do regime da prova é portanto o de fornecer no exercício da função jurisdicional um standard médio nos resultados da instrução probatória, que no maior número dos casos permitirá atingir um grau satisfatório de aproximação da verdade, mas que pode também sacrificar alguns aspectos peculiares do caso que 
O juiz tem o poder-dever ${ }^{52}$ de desenvolver a atividade probatória, estruturando as provas a serem produzidas pelas partes e valendo-se dos seus poderes instrutórios para atingir essa finalidade, mas o seu ativismo deve ser mensurado de acordo com a disponibilidade do direito material controvertido, de modo que a atuação judicial seja concentrada nas demandas que envolvem direitos indisponíveis.

A influência dessa intensidade dos poderes instrutórios do juiz sobre a técnica de distribuição dinâmica será examinada mais adiante, no Capítulo 6, quando faremos a confrontação da referida técnica com a prática forense.

\subsection{Direito à prova ${ }^{53}$ como garantia constitucional}

A Constituição Federal assegurou a garantia do acesso à Justiça, mas a concretização desse acesso passa, necessariamente, pelo direito à prova, assim caracterizado pela disponibilização de amplos mecanismos para a demonstração das alegações de fato das partes, do efetivo contraditório e da observância do devido processo legal. Sem a disponibilização para as partes de meios adequados à demonstração dos fatos que embasam as suas respectivas pretensões, o acesso à justiça se torna uma mera formalidade, e o seu efetivo escopo, que é assegurar a obtenção da tutela jurisdicional, não é atingido.

Ao lado do dever do juiz buscar a verdade para melhor decidir, como vimos defendendo nos itens precedentes, em relação às partes, é mesmo possível se sustentar uma garantia constitucional ao mais amplo acesso às provas lícitas e pertinentes para demonstrar a veracidade de suas alegações e, assim, poder influenciar o julgamento final.

oferecem particulares dificuldades às indagações ou se afastam mais dos esquemas da mais frequente realidade cotidiana" (Manual..., cit., v. 2, p. 82).

52 Para FlÁvio LUIZ YARSHELl são apenas poderes (e não poderes-deveres), pois não seria "realista" imaginar que o juiz devesse engajar-se "de forma incondicionada na descoberta da verdade" em todos e quaisquer processos, e sequer haveria uma utilidade "social" em tal tipo de providência. Ademais, não seria possível idenficar um dever do juiz de desenvolver a prova, "na medida em que a parte inerte noa pode invocar sua própria omissão para acoimar de inválida ou injusta uma decisão judicial porque também inerte teria sido o juiz" (Antecipação da prova sem o requisito da urgência e direito autônomo à prova. São Paulo: Malheiros, 2009, p. 119-120).

53 Utilizamos a expressão "direito à prova" mais pelo costume do que pela precisão técnica, pois a rigor não se trata de um direito, mas de um poder (poder de exigir a produção de prova), como alerta DinAMARCO, que refuta o emprego dos termos "direitos" e "obrigações" no âmbito do processo, "porque os deveres impostos aos seus sujeitos têm por objeto imediato a criação de situações processuais e não a obtenção de um bem da vida" (Instituições..., cit., v. 2, p. 211). 
Embora o texto constitucional não preveja expressamente o "direito à prova", é incontestável que esse direito/garantia decorre de outras garantias constitucionais, como o acesso à justiça, o devido processo legal, o contraditório e a ampla defesa (incisos XXXV, LIV e LV do artigo 5. ${ }^{\circ}$ da Constituição Federal), encontrando amparo, portanto, constitucional.

Da mesma forma, na esfera infraconstitucional é possível sustentar a previsão do direito à prova, diante do que dispõe o artigo 332 do Código de Processo Civil, bem como do regramento dos meios de prova previstos no Código Civil $^{54}$ e no Código de Processo Civil.

Tais regras materiais e processuais também têm a função de estabelecer limites à instrução probatória, que no confronto com outras garantias constitucionais, como a individualidade, a privacidade e a intimidade, devem ser sopesadas pelo magistrado para balancear os interesses dos envolvidos. Daí por que o direito à prova não pode ser visto como um valor absoluto, encontrando na própria Constituição restrições, principalmente para a manutenção da licitude dos meios probatórios.

As restrições ao direito à prova não se limitam ao cabimento de certas provas. No desenvolvimento do processo, o juiz pode dispensar a realização de certas provas que, mesmo lícitas, encontram-se completamente impertinentes. ${ }^{55}$

54 O artigo 212 do Código Civil relaciona, ainda que de forma imperfeita, os meios pelos quais "o fato jurídico pode ser provado". Os equívocos são vários, destacando-se os seguintes: (i) não apenas os fatos jurídicos podem ser provados pelos meios relacionados, mas também outras alegações de fato, que não têm qualquer efeito jurídico, podem necessitar de prova e serem para o deslinde da controvérsia, tal como os eventos naturais; (ii) a referência à "presunção", no singular, sem qualquer qualificação (relativa ou absoluta), além de possibilitar confusão, também é despropositada, pois nem a presunção relativa nem a presunção absoluta são meios de prova (a primeira está relacionada à distribuição do ônus da prova e a segunda ao direito material que dispensa a prova); (iii) confunde-se fonte de prova (documento e testemunha) com resultado da prova (confissão) e com meio de prova (perícia); e (iv) não relaciona todos os meios de prova típicos do Código de Processo Civil (omite-se a inspeção judicial). Como resume BARBOSA MOREIRA, o legislador "mistura alhos com bugalhos e esquece distinções fundamentais", recomendando que "muito preferível teria sido renunciar à pretensão enumerativa; num quadro normativo em que, para gregos e troianos, perdão, para civilistas e processualistas, continua a viger o princípio da não taxatividade [...], o melhor alvitre consistiria em deixá-lo reinar a plena luz [...]" (Anotações sobre o título "Da prova" do novo Código Civil. Revista Trimestral de Direito Civil, Rio de Janeiro: Padma Editora, v. 6, n. 22, p. 112, abr.-jun. 2005).

A questão sobre a pertinência será sempre dotada de certo grau de subjetividade, que pode ser minimizado se os pontos controvertidos forem adquadamente fixados no "despacho saneador" e as provas devidamente ordenadas nessemomento processual, oportunizando às partes a realização das respectivas provas. 
A garantia do acesso à justiça, mais do que sob o aspecto formal, assim compreendido o mero direito de pleitear algo em juízo, ${ }^{56}$ é aquela assegurada pela Constituição: o "acesso à ordem jurídica justa", o que equivale à garantia de fazer uso do Poder Judiciário para exigir, declarar ou constituir determinado direito, podendo fazê-lo ao valer-se de todos os meios legítimos para que esse direito seja exigido, declarado ou constituído, de maneira que o objetivo final do processo (a concessão da tutela jurisdicional) tenha o resultado mais próximo possível do direito violado ou ameaçado. ${ }^{57}$

Para que esse resultado possa ser "justo", o processo deve, inicialmente, ser o mais ágil e tempestivo possível, mas a mera "aceleração" do trâmite processual não assegura uma tutela efetiva. ${ }^{58}$ É essencial que o julgamento esteja calcado em um juízo de certeza, ou o mais próximo desta, e que o convencimento do julgador se forme, essencialmente, pelos elementos de prova produzidos nos autos (pelas partes, de ofício ou mesmo espontaneamente).

Não basta alargar as vias de acesso ao Poder Judiciário. É preciso aprimorar os mecanismos internos do processo para que a promessa do acesso à justiça (e à tutela jurisdicional) seja tempestiva, efetiva e qualificada. ${ }^{59}$

56 É inconteste que a facilitação do acesso ao Poder Judiciário deve ser ampliado, como já se tem feito com a possibilidade de isenção das custas e com a criação dos Juizados Especiais Cíveis, que, além de isentar de custas, permite a propositura de demandas sem o patrocínio de um advogado, desde que o valor em discussão seja inferior a 20 salários mínimos (artigo 9..$^{\circ}$ da Lei n. ${ }^{\circ}$ 9.009/1995).

Nas palavras de GIUSEPPE CHIOVENDA, "o processo deve dar, quanto for possível praticamente, a quem tenha um direito, tudo aquilo e exatamente aquilo que ele tenha direito de conseguir" (Principios de derecho procesal civil. Madrid: Reus, 1922. v. 1, p. 99, e Instituições de direito processual civil. Tradução J. G. Menegale. 2. ed. São Paulo: Saraiva, 1965. v. 1, p. 46.

A celeridade do procedimento foi, durante os últimos anos, quase que uma "obsessão" da doutrina e do legislador pátrio, como podemos extrair das reformas processuais de 1994 (Lei n. ${ }^{\circ}$ 8.952), 2002 (Lei n. $\left.{ }^{\circ} 10.444\right)$ e 2005 (Leis $n .^{\text {os }} 11.187$ e 11.232), além de sua elevação à condição de garantia constitucional, por força da Emenda Constitucional n. ${ }^{\circ} 45$, de 30.12.2004, que introduziu o inciso LXXVIII ao artigo $5 .^{\circ}$ da Magna Carta assegurando o tempo razoável do processo. Ainda que seja uma preocupação relevante, não pode ser tida como a única solução para o problema da efetividade, pois a justiça da decisão mede-se também pelo seu conteúdo, e não apenas pela forma ou pelo tempo. Como leciona BEDAQUE, "processo efetivo é aquele que, observado o equilíbrio entre os valores segurança e celeridade, proporciona às partes o resultado desejado pelo direito material" (Efetividade..., cit., p. 49, grifos do autor). No mesmo sentido, JosÉ RoGÉRIO CRUZ E TUCCI sustenta “a preocupação global em torno da duração intolerável dos feitos é patente, já que esta configura um enorme obstáculo para que o processo cumpra seus compromissos institucionais. O tempo pode causar o perecimento das pretensões, ocasionar danos econômicos e psicológicos às partes e profissionais aos operadores do direito, estimular composições desvantajosas, e consequentemente, gerar descrédito ao Poder Judiciário e ao Estado como um todo" (Tempo e processo: uma análise empírica das repercussões do tempo na fenomenologia processual (civil e penal). São Paulo: RT, 1997, p. 89). são desejados: (i) a assistência jurídica aos necessitados; (ii) a ampliação das tutelas coletivas lato 
Portanto, é primordial para se efetivar o acesso à ordem jurídica justa que no curso do processo seja assegurado às partes o amplo acesso aos meios de prova, desde que, evidentemente, pertinentes e admissíveis, sob o risco de se perpetuar a fase instrutória, o que ofenderia a já comentada (e sempre desejada) celeridade.

Sem acesso à prova, as pretensões das partes estariam fadadas ao insucesso, porquanto não seria possível influir sobre o convencimento do juiz, e assim a garantia do acesso à justiça voltaria a ser apenas "formal”, uma vez que desprendido do resultado “justo" que deve ser sempre buscado pelo órgão julgador.

A adequação e o balanceamento dos valores celeridade e segurança (que não se excluem, mas se completam) ${ }^{60}$ serão realizados pelo magistrado, notadamente pela observância da garantia constitucional do devido processo legal, garantia-síntese que abrange a ampla defesa e o contraditório. ${ }^{61}$

Por meio da garantia do devido processo legal, além de se assegurar às partes a possibilidade de produzir as provas necessárias à comprovação de suas respectivas alegações de fato, pelos meios legalmente previstos e outros moralmente legítimos, o magistrado fica impedido de criar obstáculos não razoáveis à produção e à utilização das provas. $^{62}$

O que se procura assegurar com o direito à prova é o acesso à tutela jurisdicional, mas esta somente será legítima e justa se for permitido às partes ampla

sensu; e (iii) o aperfeiçoamento da técnica processual aplicada no caso concreto (Acesso à justiça. Tradução E. G. Northfleet. Porto Alegre: Fabris, 1988. p. 31-73).

BARBOSA MOREIRA, ao discorrer sobre os riscos de uma busca incessante pela efetividade, adverte que "se corre o perigo de romper o equilíbrio do sistema, hipertrofiando uma peça em detrimento das restantes. É o que acontece, por exemplo, quando se estende além da medida razoável a duração do feito, pelo afã obsessivo de esgotar todas as possibilidade, mínimas que sejam, de apuração dos fatos. Nem o valor celeridade deve primar, pura e simplesmente, sobre o valor verdade, nem este sobreporse, em quaisquer circunstâncias, àquele". (Efetividade..., cit., p. 22).

Nas palavras de NELSON NERY JR., "[...] bastaria a norma constitucional haver adotado o princípio do due process of law para que daí decorressem todas as consequências processuais que garantiriam aos litigantes o direito a um processo e uma sentença justa" (Princípios do processo civil na Constituição Federal. 5. ed. São Paulo: RT, 1999. p. 30).

62 Na opinião de EDUARDO CAMBI, o direito constitucional à prova "visa assegurar a possibilidade de as partes se valerem de todos os meios de prova que se revelem idôneos e úteis para demonstrar a verdade ou falsidade dos fatos alegados e que sirvam como suporte para as suas respectivas pretensões e defesas. Compreende, também, a proibição ao legislador infraconstitucional de colocar obstáculos não razoáveis que impeçam ou dificultem a utilização das provas dos direitos buscados em juízo" (Direito constitucional à prova no processo civil. São Paulo: RT, 2001. p. 45-46; grifos do autor). 
participação, assim compreendido o processo em que as partes têm acesso à informação, possibilidade de manifestação e comprovação das suas alegações e efetiva participação na formação do convencimento do julgador, isto é, o processo que se desenvolve em contraditório. $^{63}$

A possibilidade de amplo acesso às provas, portanto, constitui um dos elementos de legitimação do contraditório e espelha o objetivo da garantia da ampla defesa que, embora se desdobre em duas vertentes (assegurar todos os meios de defesa e recursos cabíveis, e garantir a demonstração das alegações de fato), visa permitir que as partes se valham de todos os meios para provar as alegações de fatos que sustentam as suas respectivas pretensões.

Nesse contexto de direito processual constitucional, em que a satisfação da tutela jurisdicional de forma justa exige a observância de um processo democrático, em que a participação das partes deve ser assegurada com amplitude e efetividade, o direito à prova emerge como uma condição essencial para o atingimento dos escopos da jurisdição e mesmo a sua legitimação.

Em paralelo ao direito à prova, a distribuição do ônus da prova, como mecanismo de estruturação da prova, tema a ser mais bem explorado adiante, tem papel fundamental para permitir o efetivo exercício do direito à prova, pois visa definir as atribuições de cada uma das partes quanto às alegações que necessitam ser provadas e à ordem em que devem ser produzidas.

63 O conceito tradicional de contraditório, calcado no binômio "necessidade de informação" e "possibilidade de reação", de que participavam apenas as partes, está superado na sistemática do direito processual moderno, que exige uma interlocução constante entre as partes e o juiz, que também é sujeito do contraditório e que somente se realiza se as partes tiverem amplo acesso a todos os atos processuais, conhecimento das providências que o juiz entenda pertinentes, possibilidade de desincumbir-se dos seus ônus e exercer suas faculdades, além de influenciarem a formação de convencimento do magistrado, o que somente se mostra cabível se lhes for oportunizado propor a realização de provas, produzir as provas e outros esclarecimentos e opinar sobre as provas produzidas. Como prega ANTONIO DO PASSO CABRAL, o contraditório deve ser concebido "como direito de influência, ou seja, o direito de condicionar a formação da vontade estatal. Tendo como pano de fundo a ideia habermasiana de democracia deliberativa, pensamos ser possível imaginar o contraditório como expressão processual da influência, forma mais ampla e moderada de poder. Se as manifestações das partes não representam signo de poder estatal, podem-se incluir no espectro da influência, com objetivo de condicionar a decisão do Estado-juiz. O contraditório como direito de influência, além de inserir os sujeitos processuais no contexto de um debate judicial pluralista contribuinte para a decisão final, admite a possibilidade de procedimentos não judiciais observarem o contraditório" (O contraditório como dever e a boa-fé processual objetiva. Revista de Processo, São Paulo: RT, n. 126, p. 75, ago. 2005). 
Ainda nessa perspectiva de garantia do direito à prova, a técnica de distribuição dinâmica do ônus da prova pode atuar como um elemento facilitador de observância dessa garantia, permitindo um deslocamento de ônus probatório quando verificado um desequilíbrio na capacidade probatória das partes, sempre visando à produção das provas que possam influenciar no convencimento do julgador.

\section{$1.4 \quad$ Verdade, certeza, probabilidade, verossimilhança e dúvida}

A prova, como retrato histórico de um fato, nem sempre terá condições de refletir com exatidão a forma como os eventos se sucederam e o processo deve estar dotado de mecanismos para trabalhar com diferentes níveis de percepção da verdade para emissão do pronunciamento final.

Em uma concepção epistêmica, a verdade que se busca no processo é aquela que pode ser racionalmente provada, e verdadeiro é aquilo que foi provado. ${ }^{64}$

Ou, como leciona MOACYR AMARAL SANTOS, "provar é convencer o espírito da verdade respeitante a alguma coisa", 65 que, no processo, equivale ao convencimento sobre os fatos aludidos pelas partes como fundamento (causa de pedir) das suas pretensões (pedido).

Nesse sentido, seria mesmo possível falar em uma "verdade processual", sendo despropositadas as distinções que se procuram fazer entre verdade "absoluta" ou "real", e verdade "relativa" ou "formal".

Com efeito, o que se busca no processo é a convicção do juiz para decidir, que corresponde a uma crença na verdade como legítima, ${ }^{66}$ por meio de um sistema de

64 Segundo JORDI FERRER BELTRÁN, a relação entre prova e verdade é teleológica, ou seja, finalística: a finalidade da prova "es la de permitir alcanzar el conocimiento acerca de la verdad de los enunciados fácticos del caso" (Prueba y verdad en el derecho. 2. ed. Madrid: Marcial Pons, 2005. p. 74).

Para MALATESTA, "sendo a prova o meio objetivo pelo qual o espírito humano se apodera da verdade, a eficácia da prova será tanto maior quanto mais clara, mais plena e mais seguramente ela induzir no espírito a crença de estarmos de posse da verdade. Para se conhecer, portanto, a eficácia da prova, é preciso conhecer como se refletiu a verdade no espírito humano, isto é, importa conhecer qual o estado ideológico, relativamente à coisa a verificar, que ela criou no nosso espírito com a sua ação" ( $A$ 
persuasão racional e motivado, que está condicionado aos fatos em que se funda o conflito, às provas desses fatos regularmente colhidas no processo e às regras legais e máximas da experiência de determinado tempo e local (Iudex iudicare debet secundum allegata et probata, non secundum conscientiam).

Para a formação dessa convicção do juiz é irrelevante que a verdade seja "absoluta" ou "relativa", "real" ou "formal", até mesmo porque em termos filosóficos a verdade é sempre una, não admitindo adjetivações. As alegações de fato formuladas pelas partes ou são verdadeiras ou são falsas. O que for "meio" verdadeiro também é "meio" falso, ${ }^{67}$ e o processo não pode admitir essas "variações" da verdade.

O que eventualmente pode sofrer variações é o grau de confiança no enunciado formulado pelas partes e o grau de convicção que esse enunciado provoca no juiz, como procuraremos apresentar logo adiante.

Ademais, a corroborar a impropriedade da distinção entre verdade "absoluta" ou "relativa", é certo que uma verdade "absoluta" seria inatingível no plano mundano e, consequentemente, no plano processual, pois dependeria de um conhecimento do todo, assim considerada a universalidade das coisas, não alcançável pelos homens.

Igualmente, a "relatividade" não está na verdade em si, mas no conhecimento da verdade (prova das alegações de fato), haja vista que o processo é um fenômeno cultural $^{68}$ e está inserido em um determinado contexto histórico, vinculado aos métodos disponíveis para a sua busca e à quantidade e qualidade das informações acessíveis pelas partes e pelo juiz, encontrando-se fundado na possibilidade de que o convencimento (motivado) seja verdadeiro.

lógica..., cit., v. 1, p. 19). Na síntese de MitTERMAIER, a prova é "la suma de los motivos que producen la certeza" (Tratado da la prueba en materia criminal. 3. ed. Madri: Imprenta de la Revista de Legislacion, 1877. p. 48). do evento que esse representa e, portanto, é 'absoluta' (no sentido de que não admite graus). $\mathrm{O}$ enunciado é verdadeiro ou não: não pode ser 'mais ou menos' verdadeiro. O que pode variar, dependendo das circunstâncias, é o grau de confirmação" (Uma simples verdade..., cit., p. 105). inevitavelmente de sua cultura. Ora, falar em cultura é falar em valores, pois estes não caem do céu, nem são a-históricos, visto que constituem frutos da experiência, da própria cultura humana, em suma" (Do formalismo no processo civil: proposta de um formalismo-valorativo. 4. ed. São Paulo: Saraiva, 2010. p. 92). 
Assim, no âmbito do processo, a busca pela verdade será sempre relativa e objetiva. Relativa porque calcada em "provas que justificam o convencimento do juiz, representando a base cognoscitiva na qual o convencimento de que um determinado enunciado corresponda à realidade dos fatos da causa encontra justificativa". ${ }^{69}$ E objetiva porque "não é fruto de preferências subjetivas e individuais do juiz, fundando-se em razões objetivas que justificam seu convencimento e derivando dos dados cognoscitivos resultantes das provas". 70

Portanto, mais relevante do que a verdade em si, no âmbito processual as preocupações devem se concentrar nas técnicas e metodologias que podem ser empregadas na tentativa de se conhecer e determinar a verdade possível no processo (truth-acquiring), que podem ser mais ou menos eficazes, de acordo com o modelo de descoberta da verdade empregado e o grau de evolução dos meios probatórios disponíveis, mas que sempre resultarão em um conhecimento limitado/parcial da verdade. ${ }^{71}$

O método pelo qual o juiz conhece e valora os fatos (e o direito aplicável na espécie) é a instrução, que corresponde a todo o procedimento preparatório à tomada de decisão e emissão do provimento jurisdicional, inclusive as "alegações finais" das partes, nas quais emitem o seu juízo de valor sobre o resultado da fase probatória e propõem a interpretação jurídica das alegações de fato e suas consequências, "destinadas a produzir convicção no espírito do juiz". ${ }^{72}$

$\mathrm{Na}$ instrução, o magistrado, por si ou por intermédio das partes, deve colher todos os elementos pertinentes à percepção dos fatos e à formação da sua convicção ${ }^{73}$, para

TARUFFO, Michele. Uma simples verdade..., cit., p. 106.

TARUFFO, Michele. Uma simples verdade..., cit., p. 106. Para DANIEL MITIDIERO, "a verdade é objetiva - ela existe fora do sujeito que a investiga - e é relativa - o conhecimento que dela se pode obter normalmente é fundado em um retrato imperfeito da realidade, seja pelos instrumentos à disposição para conhecê-la, seja pelo contexto em que deve ser investigada" (Antecipação da tutela: da tutela cautelar à técnica antecipatória. 2. ed. São Paulo: RT, 2014. p. 97-98; grifos do autor).

Trata-se de uma verdade axiológica, ou seja, "o adequado juízo de valor que a sociedade endereça a fatos como os que no processo em exame se revelaram" (DINAMARCO, Cândido Rangel. $A$ instrumentalidade..., cit., p. 275), e o enquadramento que estes fatos têm no ordenamento jurídico dessa determinada sociedade, em certo momento histórico.

DINAMARCO, Candido Rangel. Instituições..., cit., v. 3, p. 34.

Ou seja, o juiz parte de um estado de ignorância e ao longo do processo o seu grau de convencimento vai aumentando, podendo ou não chegar ao estágio da certeza. Não obstante a evolução da convicção ser progressiva, para fins didáticos, preferimos partir do maior grau de convicção para o menor. 
que possa decidir com base em sua convicção e, tanto quanto possível, segundo a verdade e a justiça, mas não decidir sobre a verdade. ${ }^{74}$

No estado de certeza, assim entendida a conformidade psíquica com a verdade, o espírito do julgador já desenvolveu uma crença na verdade (afirmação preliminar da verdade), ${ }^{75}$ a partir de um raciocínio lógico que afastou por completo os motivos divergentes e aceitou os motivos convergentes, que são confirmados a partir da valoração dos elementos de prova colhidos no processo e que permitem ao julgador formar o seu convencimento de que a sua crença é legítima e condiz com a realidade.

Contudo, é preciso que se reconheça a incapacidade de reconstrução e assimilação integral da verdade ou mesmo da formação plena da convicção (certeza) sobre as alegações de fato para o posterior pronunciamento de mérito (quando cabível). ${ }^{76}$

Essa incapacidade ocorre, inicialmente, porque o processo faz uma reconstrução histórica dos fatos a partir da percepção das partes interessadas e de terceiros, que transmitem ao juiz os sinais do que vivenciaram, e, segundo CALAMANDREI, "il giudizio storico è sempre soltanto um calcolo di probabilità", mas para justificar certas decisões, "nel momento finale del giudicare, interviene nella conscienza del giudice una specie di illuminazione irrazionale, um vero e próprio atto di fede, che trasforma la probabilità in certezza". 77

74 Para fins de concessão da tutela jurisdicional justa e efetiva, com efeito vinculante e força de coisa julgada, espera-se que esteja conforme a verdade, mas nunca com a finalidade de declarar a verdade. Como afirma PIERo CALAMANDREI, "el fin último de la jurisdicción en toda manifestación suya es el de la observancia práctica del derecho: el razonamiento hecho por el juez en el proceso de cognición no vale como enunciación de verdad teórica, sino como proclamación práctica de un mandato que debe ser obedecido" (Instituciones de derecho procesal civil. Tradução S. S. Melendo. Buenos Aires: Depalma, 1943. v. 1, p. 87-88; grifos do autor).

75 Como alerta MOACYR AMARAL SANTOS, "a certeza, como estado de espírito, pode não corresponder à verdade. A certeza e a verdade nem sempre coincidem: por vezes tem-se a certeza do que objetivamente é falso; por vezes duvida-se do que objetivamente é verdade; e a própria verdade, que parece certa para uns, aparece como duvidosa a outros, e por vezes até como falsa ainda a outros" (Prova..., cit., v. 1, p. 14).

76 Alguns autores sustentam que seria mesmo impossível um julgamento calcado na certeza. Nesse sentido, DinAMARCo leciona que "[...] a exigência de certeza é somente uma ilusão, talvez uma generosa quimera. Aquilo que muitas vezes os juristas se acostumaram a interpretar como exigência de certeza para as decisões nunca passa de mera probabilidade, variando somente o grau da probabilidade exigida e, inversamente oss limites toleráveis dos riscos" (A instrumentalidade..., cit., p. 281), sendo que, para fins de julgamento, deveria haver um "juízo de probabilidade suficiente". Verità e verosimiglianza nel processo civile. Studi sul processo civile. Padova: Cedam, 1957. v. 6, p. 113. 
Outro elemento limitador é a abrangência horizontal da cognição, que é estabelecida unicamente pelas partes ao definirem a(s) causa(s) de pedir e a(s) causa(s) de resistir $^{78}$ de suas respectivas pretensões, ficando o juiz adstrito a conhecer e julgar conforme esses limites, sob pena de nulidade (artigos 128 e 460 do Código de Processo Civil).

Por fim, a própria falibilidade humana na valoração das provas e, consequentemente, na formação do quadro fático da causa inviabiliza o conhecimento integral dos fatos, devendo o sistema estar dotado de mecanismos para minimizar o risco de erro e, eventualmente, tentar resolvê-lo.

Ainda que a possibilidade de cognição do juiz seja limitada e nem sempre o julgamento esteja calcado em um juízo de certeza, existem outros graus de convencimento que permitem ao juiz uma tomada de decisão antes de se valer da regra de distribuição do ônus da prova prevista no artigo 333 do Código de Processo Civil, que se aplica, como veremos adiante, às situações de completa ausência de elementos probatórios ou de sua insuficiência para gerar um grau mínimo de convencimento no julgador (estado psíquico de dúvida ou credulidade). ${ }^{79}$

Em um grau abaixo da certeza encontramos o estado de probabilidade, em que as alegações de ambas as partes possuem motivos convergentes e divergentes idôneos (não é possível a rejeição integral de um deles), mas se observa uma preponderância das alegações de uma das partes sobre as de seu adversário, ou seja, a valoração das provas apontou a prevalência das alegações dessa parte como mais convincentes, sem que, contudo, pudessem excluir por completo as contrárias. Diferencia-se da certeza porque

78 Ou "pretensão do autor" e "pretensão do réu", como prefere HEITOR SICA, em face da condição do réu também pedir (demandar) em face do autor (mesmo que seja apenas para negar a pretensão do autor), e não apenas resistir ao pedido do autor ( $O$ direito de defesa no processo civil brasileiro: um estudo sobre a posição do réu. São Paulo: Atlas, 2011. p. 251-258).

Vale ressaltar que, conforme PIERO CALAMANDREI, não obstante o grau de conhecimento do juiz ou mesmo no caso de não convencimento, o pronunciamento final terá sempre a mesma "resistência jurídica, qualquer que seja o grau de certeza psicológica em que teve origem" (Verità e verosimiglianza nel processo civile. Studi..., cit., v. 6, p. 114). Ou seja, a sentença produz o mesmo efeito vinculante, independentemente do grau de convicção em que foi proferida. Por certo que esta assertiva admite exceções, como no caso das ações coletivas julgadas improcedentes por ausência ou insuficiência de provas, que apenas produzem coisa julgada secundum eventum probationis (ação civil pública, ação popular, mandado de segurança etc.). 
nesta os motivos divergentes, embora existentes, ficam completamente afastados, enquanto na probabilidade eles ficam suplantados. ${ }^{80}$

A consequência natural de um julgamento calcado em um juízo de probabilidade é o maior risco do erro. Este risco, contudo, se torna suportável na medida em que todo e qualquer juízo histórico é imperfeito (ou "incompleto", segundo LIEBMAN). ${ }^{81}$

Afastando-se ainda mais da certeza, o próximo grau de convicção é a verossimilhança ou "credibilidade", na definição de MALATESTA, ${ }^{82}$ na qual os motivos convergentes e os motivos divergentes são equivalentes, e a escolha de uma das posições se dá, segundo CALAMANDREI, com base nas máximas de experiência ("quod plerumque accidit"), ou seja, conforme aquilo que normalmente acontece em casos semelhantes àquele que está sendo examinado em juízo. ${ }^{83}$

Probabilidade e verossimilhança não se confundem, primeiro porque no naquela há um desequilíbrio entre os motivos convergentes e divergentes, já nesta os motivos convergentes e os divergentes estão equilibrados (se quivalem), segundo porque a probabilidade aproxima-se da verdade e a verossimilhança aproxima-se da normalidade. ${ }^{84}$

80 Como afirma MALATESTA, “eis como já é fácil estabelecer a diferença entre a probabilidade de um lado, e a certeza com motivos divergentes do outro. A probabilidade procura os motivos convergentes e divergentes, e os julga todos dignos de serem tomados em conta, se bem que mais os primeiros e menos os segundos. A certeza acha, ao contrário, que os motivos divergentes da afirmação não merecem racionalmente consideração, e por isso afirma. Esta afirmação surge para o espírito humano como correspondente à verdade; e a certeza que dela deriva, como qualquer outra certeza, não é mais que consciência da verdade". E conclui: “é necessário este repúdio dos motivos divergentes, para se ter certeza [...]" (A lógica..., cit., p. 64).

"[...] a declaração de certeza dos fatos se forma sempre em função dos elementos de prova existentes nos autos e sua maior ou menor completude, Mas, do ponto de vista jurídico, estes inevitáveis motivos de relatividade são superados pela decisão concreta, a qual adquire eficácia vinculante e imutável, realizando assim sua função de certeza, sem mais depender da intrínseca validade das premissas lógicas que levaram à sua formação" (Manual..., cit., v. 2, p. 81).

A lógica..., cit., p. 20.

Nas palavras do aludido autor, "l'esperienza ci insegna che fatti di quella stessa categoria avvengono normalmente in circostanze simili a quelle che si riscontrano nel caso concreto, si desume da questa esperienza che anche il fatto in questione si presenta coll'apparenza di ser vero; e viceversa si conclude che esso è inverosimile, quando, pur potendo esser vero, sembra però in contrasto col criterio suggerito dalla normalità" (Verità e verosimiglianza nel processo civile. Studi..., cit., v. 6, p. 117).

84 Como distingue MITIDIERO, "afirmar que determinada alegação é provável significa dizer que a proposição corresponde em determinada medida à verdade. Isso quer dizer que a probabilidade concerne a uma alegação concreta e indica a existência de válidas razões para tomá-la como correspondente à realidade. A verossimilhança, de outro lado, não diz respeito à verdade de 
Independentemente da intensidade, a indefinição do convencimento do juiz é pertinente tanto para as questões de fato (e principalmente em relação a elas), mas também para as questões de direito, de modo que o juiz pode não estar convicto de qual norma de direito objetivo é a aplicável na espécie, fato que decorre da evolução natural do direito, que se transforma constantemente, bem como pode advir do desconhecimento do texto da norma por parte do julgador (embora prevaleça a máxima iura novit curia), notadamente em um panorama como o nosso, em que vivemos uma verdadeira "inflação legislativa".

Há situações, ainda, em que mesmo com o regular desenvolvimento da instrução probatória, no momento da valoração da prova, o juiz ainda não consegue formar um juízo de convicção mínimo, ou seja, sequer é possível um juízo de verossimilhança, permanecendo em um estado de incerteza quanto às alegações de fato, correspondente ao estado psíquico da dúvida.

Não obstante tal quadro, diante do princípio da inafastabilidade da jurisdição e da impossibilidade de se declarar o non liquet, o juiz deverá se valer de regras abstratas e pré-constituídas do direito processual para julgar, consistentes nas regras de distribuição do ônus da prova.

Trata-se da atividade-fim do ônus da prova, ou função objetiva do ônus da prova, sobre o qual voltaremos ao tratar especificamente da técnica processual aplicável ao ônus da prova no próximo Capítulo.

Para o que nos interessa no presente momento, cumpre apenas ressaltar que o sistema processual, consciente das imperfeições para a descoberta da verdade e formação da convicção do julgador, é dotado de "válvulas de escape" para as situações em que a instrução probatória seja inexistente ou insuficiente, quais sejam os poderes instrutórios do juiz, a distribuição estática do ônus da prova e, como propomos, de forma subsidiária, a distribuição dinâmica dos ônus probatórios.

determinada proposição. A verossimilhança apenas indica a conformidade da afirmação àquilo que normalmente acontece (id quod plerumque accidit) e, portanto, vincula-se à simples possibilidade de que algo tenha ocorrido ou não em face de sua precedente ocorrência em geral" (Antecipação..., cit., p. 99; grifos do autor). Com base nessa distinção, além dos elementos necessários à comprovação da probabilidade lógica, o mencionado autor concluiu que para fins de concessão de medidas cautelares e antecipação da tutela se faz necessária a probabilidade e não a mera verossimilhança (Op. cit., p. 99113), com o que estamos de pleno acordo. 


\section{Conclusão deste capítulo: relevância da correta instrução probatória na busca da tutela jurisdicional justa}

Como sustentamos desde o início do presente trabalho, em um Estado Democrático de Direito, o processo não pode ser uma simples promessa de solução de conflitos (prevalência do escopo jurídico), mas deve atuar como um mecanismo de pacificação social e, principalmente, de promoção da justiça (escopo social). E o processo será tanto mais justo quanto melhor for o conjunto probatório, aumentando a possibilidade de se descobrir a verdade (truth-in-evidence) e a formação do juízo de certeza no momento de julgar ("critério da eficiência"). ${ }^{85}$

Para que o processo possa revelar e concretizar essas funções primordiais, o juiz, como representante do poder estatal, deve estar dotado, tanto quanto possível, de mecanismos que lhe permitam a colheita de todas as provas potencialmente úteis (do ponto de vista do conhecimento, e não do econômico) que comprovem a veracidade das pretensões que lhe são apresentadas para decidir, o que se dá mediante a adequada instrução probatória, de modo a se "ordenar o desenvolvimento do processo" e se "garantir em cada momento da instrução o princípio do contraditório e da igualdade das partes". ${ }^{86}$

A verdade adquire, assim, um valor social de caráter ético e político. ${ }^{87}$ Ético no sentido de que o sistema deve ser capaz de distinguir o verdadeiro do falso e pregar as virtudes daquele. Já o caráter político se revela na verdade como um pressuposto de

85 “[...] quanto mais a decisão levar em conta todos os fatos que na realidade estão à base do conflito específico e efetivo gerador do processo, mais será capaz de desempenhar a própria função de justa solução da controvérsia" (TARUFFO, Michele. Uma simples verdade..., cit., p. 235-236). No mesmo sentido, BARBOSA MOREIRA assevera que "[..] com poucas exceções, só por meio das provas tem o juiz acesso ao conhecimento dos fatos", donde conclui que "a probabilidade de atingir-se uma decisão justa cresce na razão direta do rendimento dos mecanismos probatórios. Quanto amis abundantes e mais seguros subsídios se puderem obter das provas, tanto menor a margem de erro a que ficará sujeito o órgão judicial, na hora de sentenciar [...]”. (Alguns problemas atuais da prova civil. Temas de Direito Processual: quarta série. São Paulo: Saraiva, 1989. p. 145-146).

86 LIEBMAN, Enrico Tullio. Manual..., cit., v. 2, p. 82. De modo mais enfático, BARBosA MoREIRA afirma que "É missão do processo conduzir o litígio a uma solução que corresponda, com a maior fidelidade possível, à realização do direito material no caso concreto; por conseguinte, a atividade judicial cognitiva, consciente embora das suas inevitáveis limitações, devetender à reconstituição verdadeira dos fatos, pressuposto da correta aplicação das normas jurídicas. Ora, o conhecimento humano da realidade, unilateral e fragmentário por natureza, só pode tornar-se menos imperfeito na medida em que as coisas sejam contempladas por mais de um ângulo e se ponham em confronto as diversas imagens parciais assim colhidas. (A garantia do contraditório na atividade de instrução. Revista de Processo. São Paulo: Revista dos Tribunais, v. 9, n. 35, abr./Jun., 1984, p. 231-232, grifos do autor). 
liberdade e um elo entre os cidadãos e os sistemas democráticos, que somente se sustentam pela adoção de um discurso verdadeiro.

A descoberta da verdade no âmbito processual passa, necessariamente, pela adequada estruturação de atividades conduzidas pelo juiz para obter elementos de conhecimento sobre as alegações de fato necessárias e pertinentes para a correta solução do conflito.

Logo, se por um lado a mera observância das regras e garantias processuais é insuficiente para assegurar a justiça da decisão (as próprias partes podem não ter interesse na verdade) e, por outro lado, a apuração da verdade é necessária como promessa para a correta aplicação do direito substantivo ao caso concreto, mas que também sozinha é incapaz de garantir a justiça da decisão, forçoso concluir que, para que o processo seja efetivamente justo, ele deve orientar-se a fazer com que a verdade dos fatos relevantes para o julgamento da causa seja adequadamente revelada, o que somente se mostra possível pela correta instrução probatória, eliminando-se toda e qualquer barreira ou limitação desarrazoada à apuração dos fatos.

Sob esse enfoque, a distribuição do ônus da prova apresenta-se como um relevante mecanismo da técnica processual para fomentar o esclarecimento dos fatos, ${ }^{88}$ pressionando a parte que alega um fato como fundamento da sua pretensão a produzir a prova da sua veracidade (função subjetiva do ônus da prova ou função epistêmica, como sustenta TARUFFO, ${ }^{89}$ sobre a qual discorreremos mais detidamente no item "2.3.1" deste trabalho).

Na técnica da distribuição dinâmica do ônus da prova, essa função epistêmica se potencializa, pois, como será demonstrado adiante, sua finalidade essencial, além de buscar reequilibrar as forças entre as partes litigantes, é a de otimizar a apuração dos fatos controvertidos, o que permitirá ao juiz decidir, com maior frequência, com base em um juízo o mais próximo possível da certeza (ou ao menos com alto grau de probabilidade), em vez de fundar-se unicamente na regra de distribuição do ônus da prova, decretando a

88 Como lembra LeO RosenberG, é preciso orientar as partes sobre o que deve ser provado, pois a má distribuição do ônus acarreta um mau julgamento ( La carga ..., cit., p. 88). 
derrota de uma das partes porque esta não se desincumbiu do ônus da prova que lhe cabia, sem que necessariamente as alegações da parte vencedora tenham sido adequadamente examinadas do ponto de vista de sua veracidade..$^{90}$

Estabelecidas essas premissas iniciais, focaremos o nosso estudo especialmente em um dos mecanismos disponibilizados ao juiz para desenvolver com maior eficiência a instrução probatória, consistente na técnica da distribuição dinâmica do ônus da prova, não sem antes delinearmos os elementos essenciais do instituto (o ônus, o ônus da prova e os critérios para sua distribuição) e o estudo de um mecanismo que lhe é correlato (a redistribuição do ônus da prova prevista no Código de Defesa do Consumidor), concluindo o presente trabalho com o exame da aplicação prática da técnica de dinamização à luz de outros elementos à disposição do juiz para a atribuição do ônus da prova às partes e para o desenvolvimento da instrução probatória.

$90 \quad$ O risco da dúvida, como vimos no item "1.4", é inerente ao sistema, e não propomos um modelo completamente sem riscos, o que seria impossível. Nossa proposta visa única e exclusivamente reduzir essa margem de risco aos casos estritamente necessários, em que se esgotaram todos os meios legítimos e economicamente viáveis para a descoberta dos fatos. 


\section{CAPÍTULO 2 \\ ÔNUS DA PROVA}

\section{1 Ônus $x$ obrigação $x$ dever: necessidade de uma distinção}

Antes de conceituarmos o ônus da prova, tema ao qual dedicaremos o item seguinte, faz-se necessário estabelecer precisamente o conceito de ônus e, em especial, diferenciá-lo das obrigações e dos deveres, o que sempre foi uma preocupação da ciência processual, a fim de se evitarem equívocos, principalmente em relação aos efeitos do não cumprimento do ônus, da obrigação ou do dever.

O vocábulo ônus vem do latim onus e significa encargo, peso ou fardo. Usamos esse termo em sentido geral para designar a faculdade que as partes têm de praticar um determinado ato para poder obter certo resultado ou sofrer as consequências negativas caso decida não praticá-lo, de acordo com regras preestabelecidas. ${ }^{91}$

No âmbito processual, empregamos a expressão ônus como sinônimo de faculdade da parte em praticar determinado ato necessário ou conveniente para a obtenção de interesse próprio, que uma vez não praticado traz ou pode $\operatorname{trazer}^{92}$ uma situação de desvantagem à própria parte omissa, sem, contudo, caracterizar um ato ilícito.

Como exemplos de ônus processuais, temos a propositura da demanda pelo autor, a resposta do réu, a interposição de recurso pelo derrotado, o adiantamento de custas e a produção de provas.

A par da divergência doutrinária, ${ }^{93}$ em nosso sentir, o ônus deve ser interpretado a partir de uma situação jurídica ativa da parte, caracterizada como o "poder

\footnotetext{
91 Vide vocábulo onere, por OBERDAN TOMMASO SCOZZAFAVA. Enciclopedia del Diritto. Milano: Giuffrè, 1980. v. 30, p. 104.

92 A previsibilidade ou imprevisibilidade do resultado negativo é o que diferencia o ônus "próprio" do "impróprio". Neste, existe um risco de ocorrer uma desvantagem; naquele, a desvantagem é certa.

93

Entendendo o ônus como uma situação passiva, JAMES GOLDSCHMIDT sintetizou o conceito de ônus processual como "imperativo da própria vontade" (Derecho procesal civil. Tradução L. P. Castro. Barcelona: Labor, 1936. p. 203). Para LIEBMAN, "ônus consiste na necessidade de realizar certa atividade, se se quiser evitar certo efeito danoso ou obter determinado resultado útil. [...] ônus é o
} 
ou faculdade do sujeito para executar o ato ou adotar a conduta prevista na norma como pressuposto para obter os resultados favoráveis a ele", ${ }^{94}$ pois a parte onerada sempre tem a faculdade de agir e apenas arca com os prejuízos derivados da omissão, decorrente da sua liberalidade.

No tocante às obrigações, é preciso esclarecer, inicialmente, que não é possível falar em obrigações processuais, pois na relação jurídica processual não se visa à obtenção do bem da vida (esse é o objeto da pretensão das partes), mas única e tão somente o estabelecimento de novas situações processuais de vantagens e desvantagens, representadas por poderes, faculdades lato sensu, ônus e deveres.

A noção de obrigação está intimamente relacionada a um determinado bem, que se opõe ao direito subjetivo de outra pessoa sobre o mesmo bem, em um estado de subordinação, de modo que o exercício dessas situações implica uma necessária alteração patrimonial das partes envolvidas.

A obrigação refere-se, portanto, a uma situação jurídica de direito substancial, e não processual. No âmbito processual, são os deveres que assumem essa situação de subordinação a um interesse alheio.

comportamento que alguém deve ter, se quiser conseguir um resultado favorável ao seu próprio interesse. Ele geralmente acompanha os poderes e os direitos processuais, dos quais constitui o lado negativo [...]" (Manual..., cit., v. 1, p. 37 e 123). No Brasil, DiNAMARCO acolhe esse entendimento (Instituições..., cit., p. 204, e A instrumentalidade..., cit., p. 237), embora reconheça que os ônus situam-se "em uma posição intermediária, porque se cumprem no interesse do titular mas sob a ameaça de que, se não forem cumpridos, ele se prejudica". (Instituições..., cit., v. 2, p. 201), e que "a parte tem plena liberdade de optar pela conduta ou pela omissão (daí, ser o cumprimento ou descumprimento do ônus uma faculdade), sabendo, no entanto, que se omitindo, agravará sua situação no processo (daí, tratar-se de um ônus)" (Instituições..., cit., v. 2, p. 204; grifos do autor).

ECHANDÍA, Hernando Devis. Teoria general de la prueba judicial. 6. ed. Buenos Aires: Zavalia Editor, 1988. t. 1, p. 405. No mesmo sentido, GIAN ANTONIO MICHELLI, embora reconheça o caráter imperativo da norma instituidora de um ônus, sustenta que "también en la hipótesis en que establece como necessaria la conducta respecto de un cierto fin, a cuya obtención el sujeto es libre de determinarse o no, esto es, según que quiera ejercitar o bien que no quiera, el poder que el derecho objetivo le confiere". (La carga de la prueba. Tradução S. S. Melendo. Bogotá: Temis, 2004. p. 66). Confira-se, ainda, a posição de EMILIO BETTI, que visualiza o ônus como forma de poder da parte (Diritto processuale civile italiano. 2. ed. Roma: Società Editrice del Foro Italiano, 1936. p. 57). Na doutrina pátria, LUIZ EDUARDO BOAVENTURA PACÍFICO também adota esse posicionamento, asseverando que "a obrigação é uma situação jurídica passiva, enquanto o ônus é uma situação jurídica ativa, manifestação do poder no qual se manifesta a liberdade de agir do sujeito onerado" ( $O$ ônus da prova. 2. ed. São Paulo: RT, 2011. p. 42). Confira-se, ainda, o posicionamento de FREDIE Didier JÚNIOR e PEDRo HENRIQUe PEDROSA NoGUEIRA, para quem o ônus "trata-se de um poder atribuído ao sujeito para prática de determinado ato no processo, sem uma situação de sujeição correlata", concluindo que "ônus não é aquilo que o titular da situação jurídica sofre, mas aquilo que lhe é lícito fazer" (Teoria dos fatos jurídicos processuais. 2. ed. Salvador: JusPodivm, 2013. p. 128129). 
O elo que aproxima o ônus, a obrigação e o dever é o elemento formal, qual seja a existência de um vínculo de vontade, haja vista que o resultado dependerá sempre da escolha da parte incumbida.

As distinções que se podem estabelecer entre ônus, obrigações e deveres são, contudo, inúmeras.

FRANCESCO CARNELUTTI foi um dos principais responsáveis pela definição das características do ônus processual e sua diferenciação da obrigação, apontando ao menos quatro elementos diferenciadores, quais sejam: a titularidade do direito protegido, a liberdade, a necessariedade e a natureza da sanção. ${ }^{95}$ Outros também serão apresentados em seguida.

O primeiro elemento diferenciador e, por certo, o mais relevante é o que CARNELUTTI denomina de elemento substancial, dado que na obrigação o vínculo da vontade se impõe para a tutela de um interesse alheio e no ônus, se impõe para a tutela de um interesse próprio. ${ }^{96}$

Como vimos, a parte onerada escolhe entre agir ou não agir, e o resultado da sua opção pela negativa é prejudicial apenas a ele próprio. Por certo que a parte contrária também tem interesse na ação ou omissão da parte onerada, pois, embora o resultado direto seja uma situação de desvantagem para essa parte, a contrária também irá beneficiar-se, ainda que de forma indireta. ${ }^{97}$

Sistema de diritto processuale civile. Padova: Cedam, 1936. v.1, p. 53-56.

96 "Obbligo e onere hanno comune l'emento formale, consistente nel vincolo alla volontà, ma diverso l'emento sostanziale, perchè il vincolo è imposto, quando vi è obbligo, per la tutela di un interesse altrui, e quando vi è onere, per la tutela di un interesse proprio" (Sistema..., cit., v. 1, p. 55; grifos do autor). Para PONTES DE MIRANDA, "a diferença entre dever e ônus está em que (a) o dever é em relação a alguém, ainda que seja a sociedade; há relação jurídica entre dois sujeitos, um dos quais é o que deve: a satisfação é do interesse do sujeito ativo; ao passo que (b) o ônus é em relação a si mesmo; não há relação entre sujeitos; satisfazer é do interesse do próprio onerado. Não há sujeição do onerado; ele escolhe entre satisfazer, ou não ter a tutela do próprio interesse". (Comentários ao Código de Processo Civil. 3. ed. Rio de Janeiro: Forense, 1997. t. 4, p. 253; grifos do autor). No mesmo sentido, LuCAS BuRIL MACÊDO e RAVI MEDEIROS PEIXOTO asseveram que é "perceptível a discrepância entre ônus e obrigação: nesta o cumprimento se faz, sobretudo, em observância de interesse de outrem, ao passo que anquele o interesse do cumprimento é do próprio agente". (Ônus $d a$ prova e sua dinamização. Salvador: Juspodivm, 2014. p. 99).

97 Se o autor deixa de produzir a prova das alegações de fato que fundamentam as suas pretensões, aumentam-se as chances de não acolhimento dessas pretensões por ausência ou insuficiência de provas. 
Já na obrigação e no dever a parte encarregada age no interesse de um terceiro ou da coletividade, sendo o cumprimento espontâneo da obrigação a satisfação do direito subjetivo alheio e o seu descumprimento, o nascedouro da possibilidade de o titular do direito exigir o seu cumprimento ante a imposição das sanções pertinentes. ${ }^{98}$ Aqui também é possível falar no interesse da parte obrigada e não apenas no interesse alheio, uma vez que o devedor tem interesse em adimplir a obrigação para libertar-se, mas, ainda que assim o faça, estará agindo no interesse (primário) do credor. A extinção da obrigação é um interesse secundário.

Outra diferença relevante consiste no fato de as obrigações e deveres serem situações ou relações jurídicas passivas, ao passo que o ônus é uma situação ou relação jurídica ativa.

Conforme já antecipamos, embora alguns autores tratem o ônus como uma situação passiva, a doutrina moderna é praticamente unânime em definir o ônus como uma espécie de faculdade e, portanto, uma situação ativa da parte onerada sem que lhe corresponda um direito da parte contrária para exigir o seu adimplemento. ${ }^{99}$

O cumprimento do ônus, segundo RoSENBERG, é uma atividade voluntária, uma faculdade de agir em benefício próprio. ${ }^{100}$ Ainda de acordo com o autor alemão, no ônus não se vislumbra uma necessidade ou um imperativo, não podendo ser imposto, mas apenas uma necessidade prática juridicamente criada, a qual, de qualquer forma, não retira

98 Para MARISTEla DA SILVA ALVES, “ônus difere de dever, pois esse pressupõe sanção. Sempre que a norma jurídica impõe um dever a alguém, em verdade está obrigando ao cumprimento, o que gera à parte oposta o direito de exigir o comportamento do obrigado. Nada disso ocorre com o ônus da prova que, no caso de descumprimento, terá apenas uma consequência processual" (Esboço sobre o significado do ônus da prova no processo civil. In: KNIJNIK, Danilo. (Coord). Prova judiciária: estudos sobre o novo direito probatório. Porto Alegre: Livraria do Advogado, 2007. p. 207).

Como sustenta Teresa ARruda Alvim WAMBIER, "o ônus difere da obrigação, entre outras coisas, por que esta é exigível, não o sendo aquele. Esta é passível de ser convertida em pecúnia, não o sendo aquele. Quando o obrigado cumpre uma obrigação, o beneficiado é aquele que se encontra no outro polo da relação jurídica. Exatamente ao contrário ocorre quando se estiver diante de um ônus". (Reflexões sobre o ônus da prova. Revista de Processo, São Paulo: RT, n. 76, p. 142, out.-dez. 1994.

$100 \quad$ Nas palavras do referido autor, "las partes tratan de eludir esta consecuencia y se esfuerzan por afirmar y probar todos los hechos que necesitan ser averiguados. Pero lo hacen por ningún otro imperativo que aquel que les impone su propio interés en triunfar" (La carga..., cit., p. 74; grifos do autor). Mesmo entendimento possui ALFREDO BUZAID, para quem "falamos de ônus, quando o exercício de uma faculdade é posto como condição para obter uma certa vantagem. Por isso ônus e uma faculdade, cujo exercício é necessário para a consecução de um interesse" (Do ônus da prova. Estudos de direito. São Paulo: Saraiva, 1972. v. 1, p. 61). 
a liberdade e a voluntariedade de agir, ainda que a omissão possa acarretar efeitos negativos.

No mesmo sentido são as lições de SAntiago Sentís Melendo ${ }^{101}$ e MiCHELLI, ${ }^{102}$ que definem o ônus como uma faculdade, uma liberdade entre fazer ou não fazer, necessária (em sentido prático e não jurídico) "ou ao menos conveniente", ${ }^{103}$ para se produzir um efeito jurídico no interesse da própria parte.

Por seu turno, as obrigações e os deveres são sempre situações passivas, de sujeição ou subordinação ao interesse alheio, de forma que a liberdade de agir é limitada, podendo a parte contrária exigir coercitivamente o seu cumprimento ou, ao menos, a imposição de uma sanção pela sua inobservância ${ }^{104}$. Há, evidentemente, um vínculo jurídico entre a parte obrigada e a outra parte ou o Estado, situação que não se verifica no ônus.

Como consequência dessa distinção, os efeitos do não cumprimento de um ônus ou de uma obrigação ou dever também são diferenciados. No ônus, caso a parte onerada não se desincumba, a sua omissão não configura um ato ilícito (ato contrário ao direito), e não implica à parte onerada nenhum tipo de coerção ou sanção, configurando meio lícito de agir, embora possa acarretar uma situação de desvantagem. ${ }^{105}$

O inadimplemento da obrigação ou do dever, por outro lado, configura uma violação ao direito e, como tal, implica um ato ilícito, sujeito às sanções legalmente previstas. $^{106}$

101 Para o processualista espanhol, o conceito de ônus difere-se da obrigação a partir da diferença "de exigibilidad frente al de libertad [...], que no puede prescindir del concepto de deber, con el cual se integra", mas o ônus não é imperativo e inevitável, mas antes "una necesidad dentro de la libertad" (Desarrollo del proceso: deberes del juez y cargas de las partes. Boletín mexicano de derecho comparado, n. 24, p. 1004, 1975).

102 La carga..., cit., p. 89-90.

103 DINAMARCO, Cândido Rangel. Instituições..., cit., v. 2, p. 204.

104 Para DidIER e NOGUEIRA, o ônus difere-se dos deveres processuais porque "no ônus há liberdade da parte onerada de se desincumbir do encargo; no dever ou obrigação, a recusa ao comportamento previsto na norma resulta num fato contrário a direito" (Teoria..., cit., p. 130).

105 Para MichelLI, o ônus é uma mera regra de conveniência, cuja inobservância não acarreta ilicitude (La carga..., cit., p. 90-91).

106 Segundo MOACYR AMARAL SANTOS, essa é a principal distinção entre ônus e obrigação, porque naquele não existe um direito que lhe seja correlato ou mesmo uma sanção pelo seu não cumprimento (Prova..., cit., v. 1, p. 94). No mesmo sentido é a lição de ROSENBERG, para quem o ônus se distingue do dever e da obrigação porque não se impõe sanção ao seu descumprimento (La carga..., cit., p. 73). 
Outra distinção que podemos fazer entre ônus, obrigação e dever é que as obrigações e os deveres podem corresponder a ações ou omissões (como as obrigações de não fazer), enquanto o ônus sempre se refere a um ato ou conduta comissiva. Ou seja, para se desincumbir do ônus sempre se exige da parte onerada que pratique um ato (sempre positivo), uma vez que sua omissão pode lhe trazer situações de desvantagem. Já o adimplemento da obrigação e/ou do dever pode decorrer da ação ou omissão do sujeito passivo (ato positivo ou negativo), conforme venha a ser definido na norma correspondente.

Por fim, podemos estabelecer uma última distinção entre o dever de um lado e o ônus e a obrigação de outro. Enquanto o ônus e a obrigação se caracterizam pela provisoriedade, o dever tem como característica básica a "perpetuidade". ${ }^{107}$ Com efeito, enquanto aqueles se esgotam com o adimplemento ou cumprimento, o dever não se extingue, respondendo as partes continuamente por seus deveres processuais.

Assim, valendo-nos dos ensinamentos de Rui MANUEL DE Freitas RANGEL,

[...] podemos concluir que o ónus é um poder ou faculdade de desenvolver e executar livremente certos actos ou adoptar ou não certa conduta prevista para benefício e interesse próprio sem qualquer sujeição ou coacção e sem que seja possível outro agente exigir a sua observância, comportando, a omissão do comportamento ou o incumprimento, um risco gerador de consequências desfavoráveis e desvantagens. ${ }^{108}$

Realizadas essas distinções elementares, podemos, agora, ingressar especificamente no tema do ônus da prova, sempre tendo em mente o conceito moderno de ônus, ou seja, uma faculdade de agir livremente em benefício próprio, sendo lícita a abstenção (sob o risco de uma desvantagem) e sem que haja coerção ao seu cumprimento ou sanção ao seu descumprimento, nem o direito da outra parte de exigir sua observância.

\subsection{Conceito e alcance do ônus da prova}

Quando falamos especificamente em ônus da prova, a definição ampla e abstrata de ônus processual é insuficiente para explicar todo o fenômeno, pois o ônus da

\footnotetext{
107 ALVIM, José Manoel de Arruda. Manual de direito processual civil. 10. ed. São Paulo: RT, 2006. v. 2, p. 436.

108 O ónus da prova no processo civil. Coimbra: Almedina, 2000. p. 94.
} 
prova possui duplo enfoque: as partes e o juiz, a caracterizar uma função "subjetiva" e uma função "objetiva" para o ônus da prova. ${ }^{109}$

MiCHELLI, embora adote uma concepção unitária sobre o ônus da prova (aceita apenas o aspecto "objetivo"), reconhece que o ônus deve ser visto sob dois ângulos diferentes e complementares (os dois lados da moeda), asseverando que:

[...] salta aos olhos, evidentemente, que todos aqueles que se detiveram em investigar o aspecto denominado subjetivo do ônus da prova se limitaram essencialmente ao exame do poder probatório correspondente às partes, mas nunca conduziram a fundo a investigação, no que foi atraído pelo outro lado da moeda, isto é, pelo denominado ônus objetivo, que lhe indicava as consequências objetivas da instrução, e precisamente as consequências da falta de certeza que ficou o juiz em relação a determinados fatos relevantes. ${ }^{110}$

No direito pátrio, ALFREDo BuZAID difundiu essa dupla visão do conceito de ônus da prova, no sentido de que:

[...] bem se vê que o problema do ônus da prova tem duas faces: uma voltada para os litigantes, indagando-se qual deles há de suportar o risco da prova frustrada. É o aspecto subjetivo. A outra voltada para o magistrado, a quem deve dar uma regra de julgamento. É o aspecto objetivo. O primeiro opera geralmente na ordem privada; o segundo, porém, é princípio de direito público, intimamente ligado à função jurisdicional. O primeiro constitui uma sanção à inércia, ou à atividade infrutuosa da parte; o segundo, ao contrário, é um imperativo da ordem jurídica, que não permite que o juiz se abstenha de julgar, a pretexto de serem incertos os fatos, porque não comprovados cumpridamente. ${ }^{111}$

Essa bipartição do ônus da prova está intimamente relacionada às finalidades do ônus probatório no processo, que também se dividem em duas.

O primeiro escopo, relacionado à função "subjetiva", consiste em fazer com que os litigantes contribuam para a formação do convencimento do magistrado, de modo

109 A distinção entre o aspecto subjetivo e o aspecto objetivo (ou formal e material) surgiu na obra de JULIUS GLASER, de 1883, denominada Handbuch des Strafprozesses (Manual de processo penal, em tradução livre), conforme citações de Rosenberg (La carga..., cit., p. 34) e Michelli (La carga..., cit., p. 95-96). CARNELUTTI também identifica os dois aspectos do ônus da prova, distinguindo entre o estímulo à ação das partes para que forneçam as provas e o mecanismo de julgamento do juiz sobre fatos desconhecidos (La prueba civil. Tradução N. A. Z. Castillo. Buenos Aires: Ediciones Arayú, 1955. p. 219-220). Esse posicionamento é reiterado no livro Instituciones del proceso civil. Tradução J. Guasp. Buenos Aires: EJEA, 1959. v. 1, p. 344). Voltaremos a tratar mais detidamente dessas funções do ônus da prova no item " 2.3 ", a seguir.

110 Tradução nossa. No original: “[...] salta a la vista evidentemente que quien se ha detenido en la indagación del aspecto denominado sujetivo de la carga de la prueba, se ha limitado en sustancia al examen del poder probatorio correspondiente a las partes, pero no ha conducido siempre a fondo la investigación, en cuanto ha permanecido atraído por la otra cara de la medalla, esto es, por la denominada carga objetiva, que le indicaba las consecuencias objetivas de la instructoria, y precisamente las consecuencias de la falta de certeza en que había quedado el juez respecto de determinados hechos relevantes" (La carga..., cit., p. 97).

Do ônus da prova. Estudos de direito. São Paulo: Saraiva, 1972. v. 1, p. 66. 
que este possa atingir certo grau de convicção sobre as alegações de fato formuladas pelas partes e, assim, apreciar o litígio calcado em um juízo de certeza (ou o mais próximo possível da certeza).

Ocorre que, como sustentamos anteriormente neste trabalho, nem sempre esse estado de certeza será atingível, ${ }^{112}$ seja pelo esforço probatório das partes ou mesmo do juiz (quando age de ofício), e os sistemas processuais modernos não admitem que o magistrado se abstenha de julgar (o artigo 126 do Código de Processo Civil veda o non liquet). Daí o segundo fim do ônus da prova, vinculado à função "objetiva", que é estabelecer uma regra para que o juiz profira uma sentença mesmo quando se encontrar em estado de dúvida ${ }^{113}$ sobre o que deveria ter sido provado, de forma a evitar decisões arbitrárias, com base em preferências ou preconceitos do juiz.

Com efeito, se após a conclusão da fase instrutória não há convicção do juiz sobre as alegações de fato de qualquer das partes, a lei determina como o magistrado deve julgar, de forma imperativa, sem prejuízo de eventual possibilidade de se reabrir a fase instrutória, como sustentam alguns autores. ${ }^{114}$

Ainda sob o aspecto objetivo, o ônus da prova tem a função de estabilizar as demandas, dando uma solução definitiva ao conflito, com força de coisa julgada, ${ }^{115}$ mesmo sem um instrumento probatório pleno e sem a formação do convencimento do julgador, sendo, assim, um meio de promoção da pacificação social. ${ }^{116}$

112 De acordo com MiCHELLI, não provar ou provar de forma insuficiente é a mesma coisa, porque o resultado da fase de valoração da prova será idêntico. Nas palavras do autor, "la eficacia de la regla de juicio se exterioriza, sobre todo, en el momento de la decisión de la controversia, cuando falten pruebas, o bien estas sean insuficientes, en modo de dejar al juez en al duda" (La carga..., cit., p. 130).

113 No estado de dúvida, conforme retrata MOACYR AMARAL SANTOS, os motivos afirmativos e negativos sobre determinado fato se encontram em igualdade, gerando a credulidade (Prova..., cit., v. 1, p. 13).

114 Esse é o entendimento de HEITOR SICA, para quem o juiz deveria, primeiro, valer-se dos seus poderes instrutórios, ou, caso desconheça a provas que ainda poderiam ser produzidas, deveria "abrir oportunidade para que as partes as indiquem" [Questões velhas e novas sobre a inversão do ônus da prova (CDC, art. 6. ${ }^{\circ}$, VIII). Revista de Processo, São Paulo: RT, v. 32, n. 146, p. 62, abr. 2007].

115 O próprio sistema processual prevê exceções, em que a coisa julgada se formará secundum eventum probationis (ação civil pública, ação popular, mandado de segurança etc.).

116 Sobre o escopo social do processo, DinAMARCO adverte que "não se busca o consenso em torno das decisões estatais, mas a imunização delas contra os ataques dos contrariados; e indispensável, para cumprimento da função pacificadora exercida pelo Estado legislando ou sub specie jurisdictionis, é a eliminação do conflito como tal, por meios que sejam reconhecidamente idôneos". E continua o citado mestre: "[...] a definitiva pacificação não se obtém enquanto não conseguida a imunização das decisões judiciais. [...] $\mathrm{O}$ advento da definitividade aplaca as incertezas e elimina o estado antissocial de insatisfação" (A instrumentalidade..., cit., p. 190 e 197; grifos do autor). 
Estabelecidos esses elementos definidores do ônus da prova, passemos à análise de como o magistrado desenvolve essa dupla função do ônus da prova no curso do processo, de modo que possa atingir adequadamente suas finalidades, em especial a de contribuir para a descoberta da verdade.

\subsection{Técnica processual: as funções do ônus da prova}

Já antecipamos no item precedente que o ônus da prova tem dupla função e dupla finalidade, ora direcionadas às partes, ora ao juiz.

Para TARUFFO, seria mesmo possível falar em uma função "privada" (ou "epistêmica") e uma função "pública" do ônus da prova. ${ }^{117}$

A função privada está no interesse das partes no êxito na demanda, que somente se revela atingível se restarem demonstrados os fatos que fundamentam suas pretensões, aproveitando-se o legislador desse interesse individual para a obtenção de uma finalidade maior, consistente na possibilidade da solução do conflito calcada na verdade dos fatos relevantes. ${ }^{118}$

Quando essa situação ideal não se realiza (a verdade não se revela das provas colhidas), surge a função publicística do ônus da prova, endereçada ao juiz, como uma regra de juízo, que define, diante da falta ou insuficiência da prova, o resultado do processo, impondo a derrota aquele a quem incumbia o ônus da prova do fato relevante que não restou comprovado. Trata-se de uma forma de atender ao interesse geral da

117 O ônus como figura processual. Revista Eletrônica de Direito Processual, Rio de Janeiro, ano 7, v. 11, p. 425-426, jan.-jun. 2013. Disponível em: <http://www.redp.com.br/arquivos/redp_11a_edicao.pdf $>$. Acesso em: 3 nov. 2014.

118 Para FlÁVIO LUIZ YARSHELL, "sob o ângulo das partes, interessadas no resultado favorável, parece mesmo ser inegável a existência de um encargo que lhes é atribuído", sendo interesse do "Estado que as partes produzam prova", como condição para o efetivo conhecimento dos fatos e prolação de decisões justas. (Antecipação..., cit., p. 49-51). Ainda segundo o autor, a função privada do ônus da prova tem papel relevante sobre o comportamento das partes no processo ou mesmo antes dele, pois, a partir do conhecimento dos respectivos ônus, as partes podem avaliar suas chances e riscos, assim como os eventuais dispêndios financeiros que terão e o tempo para obtenção de uma solução, o que pode, inclusive, incentivar a autocomposição (Antecipação..., cit., p. 65-71). 
administração da justiça, qual seja dar um fim ao conflito (interet reipublicae ut sit finis litium).

A seguir, procuraremos examinar essas funções e finalidades do ônus da prova com maior profundidade e à luz da técnica processual, como instrumentos para o atingimento dos escopos do processo.

\subsubsection{Função subjetiva do ônus da prova}

Em todo e qualquer litígio, o interesse na obtenção de um resultado favorável é o elemento essencial e natural do esforço das partes na produção dos meios probatórios. ${ }^{119}$

O ônus da prova, sob o ponto de vista das partes (ou seja, de "quem deve provar"), consiste exatamente na necessidade das partes de produzirem a prova das alegações de fato que fundam suas pretensões, para a formação do convencimento do juiz a seu favor e a obtenção da tutela jurisdicional em consonância com os seus interesses. ${ }^{120}$

A distribuição do ônus da prova, como técnica a ser utilizada pelo juiz para formação do seu convencimento, mediante a atribuição dos respectivos ônus às partes, tem um efeito coercitivo, exigindo destas o empenho na produção das provas que comprovem suas respectivas alegações de fato, sob o risco de lhes ser imposta uma desvantagem, consistente em uma sentença judicial desfavorável. ${ }^{121}$

119 Essa constatação é feita por ROSENBERG, que assevera que "[...] también el afirmar y el probar de las partes son simples presupuestos de su triunfo; el propio interés indica a cada parte la creación de estos presupuestos. Consecuentemente, la actividad afirmadora y probadora de las partes se manifiesta como emanación del interés natural que tienen en el éxito del proceso, como una necesidad práctica sin cuya satisfacción las partes perderían el proceso" (La carga..., cit., p. 79).

120 BARBOSA MOREIRA enfatiza que o maior interessado em que o juiz se convença da veracidade de um fato é a parte que pode extrair algum proveito do seu reconhecimento (Julgamento e ônus da prova. Temas de direito processual: segunda série. São Paulo: Saraiva, 1980. p. 74).

121 Trata-se de um risco porque o ônus da prova é um ônus "impróprio" ou "imperfeito", porquanto a desvantagem decorrente do seu descumprimento é possível de ocorrer, se não for possível a formação do convencimento do juiz com outros elementos de prova. Como é cediço, prevalece no sistema pátrio o princípio da comunhão das provas, ou princípio da aquisição, segundo o qual todas as provas regularmente produzidas no processo podem ser utilizadas pelo juiz para formação do seu convencimento e como fundamento para a decisão final, sendo irrelevante saber, em tal circunstância, qual das partes produziu esta prova, ou mesmo se foi realizada por ordem do juiz ou surgiu espontaneamente ou através de terceiros. Como sintetiza BARBOSA MOREIRA, "a prova, depois de feita, é comum, não pertence a quem a faz, pertence ao processo; pouco importa sua fonte, pouco 
Para alguns autores, esse efeito sobre as partes é apenas prático ${ }^{122}$ ou psicológico, ${ }^{123}$ e não jurídico, com o que não concordamos, pois o risco de uma decisão contrária aos seus interesses certamente gera para a parte mais que uma "sugestão" ou "insinuação" à produção da prova, mas uma quase "imposição" de produzir os elementos probatórios que lhe são favoráveis, sem os quais a obtenção da tutela jurisdicional em seu favor será praticamente inviabilizada.

Ainda de acordo com aqueles que negam o efeito jurídico à função subjetiva do ônus da prova, o magistrado não precisa orientar as partes sobre os respectivos ônus, pois a definição da distribuição é realizada de forma geral, abstrata e predefinida em lei, de sorte que, ao iniciar um processo, as partes já sabem como o ônus será distribuído, ${ }^{124}$ e que sem dispor do aparato probatório adequado quanto ao ônus que lhes incumbe dificilmente obterão êxito em suas pretensões.

Mais uma vez nos opomos a essa orientação, pois o processo civil constitucional exige que a instrução se desenvolva em constante diálogo e contraditório, e o juiz, como condutor do processo, deve direcionar as partes no sentido de que a descoberta e o esclarecimento dos fatos sejam factíveis, o que lhe impõe a necessidade de orientar as partes sobre os respectivos ônus e as consequências do seu não cumprimento.

A lei, ao atribuir esses ônus, gera, portanto, mais do que efeitos práticos sobre as partes, mas verdadeiros efeitos jurídicos sobre seus esforços probatórios (a viabilidade

importa sua proveniência" (O juiz e a prova. Revista de Processo, São Paulo: RT, v. 9, n. 35, p. 180, abr.-jun. 1984).

122 Nesse sentido, Michelli afirma que "el concepto de carga no es más que la expresión de una consecuencia práctica de otras reglas jurídicas" e que "el ejercicio de los poderes correspondientes a las partes está determinado por una valoración económica, por un juicio de conveniencia [...]”. ( $\mathrm{La}$ carga..., cit., p. 89-90).

123 BARBOSA MOREIRA é enfático ao dispor que o ônus subjetivo da prova tem mais relevância psicológica do que jurídica, pois o órgão judicial não se preocupa com o comportamento da parte durante a fase instrutória. Para o juiz interessa apenas analisar se após a colheita do material probatório ainda resta alguma lacuna que não foi preenchida, a impor um julgamento conforme a regra de distribuição do ônus da prova (Julgamento..., cit., p. 75-76). Na mesma linha de pensamento, ARaúJo CinTra (Comentários ao Código de Processo Civil. 3. ed. Rio de Janeiro: Forense, 2008. p. 20). Confira-se, ainda, o posicionamento de PIERO CALAMANDREI, para quem "la legge non crea a carico della parte doveri giuridici, che le possano essere imposti contro sua volontà, ma pone di fronte alla sua volontà, nel momento in cuiessa sta per determinarsi, una serie domoniti e di stimoli psicologici [...]" (Il processo come giuoco. Studi..., cit., v. 6, p. 67).

124 Embora apenas após a manifestação do réu é que as partes saberão, de fato, quais alegações necessitarão ser provadas, mas a definição de quem incumbirá esse ônus já estava previamente estabelecida. 
de obtenção da tutela jurisdicional, objetivo principal das partes interessadas que seenvolvem em um litígio).

Nesse sentido, a função subjetiva do ônus da prova deve ser entendida como uma regra de instrução ou conduta, ${ }^{125}$ a partir da qual as partes extraem os riscos por cada uma delas assumidos pela eventual frustração da prova que devem produzir no processo, para que obtenham um resultado favorável.

Essa determinação dos respectivos ônus probatórios, que em princípio é estática, poderá ser flexibilizada pelo magistrado em determinadas circunstâncias, como veremos adiante, ${ }^{126}$ para que o ônus da prova seja redistribuído entre as partes, com o intuito de se restabelecer o equilíbrio e otimizar a obtenção do conteúdo probatório e a formação do convencimento do julgador, de modo a minimizar o estado de dúvida e, consequentemente, os julgamentos calcados na regra objetiva de distribuição do ônus da prova.

Nessas hipóteses, a função subjetiva do ônus da prova se sobressai, pois não é mais a lei que define previamente a quem incumbe os ônus probatórios, por uma regra geral, abstrata e predeterminada (ela somente aponta os requisitos e condicionantes para a atribuição dos ônus probatórios às partes), mas é o juiz, à luz do caso concreto, quem estabelecerá os respectivos ônus das partes, organizando a instrução processual de acordo com a necessidade de "rebalanceamento" das cargas probatórias, a que atribuímos a denominação de "efeito gangorra" da distribuição do ônus da prova.

Utilizamos a alusão à figura da gangorra pois ela é capaz de representar perfeitamente a situação das partes na demanda. Em regra, as partes conflitantes se veem em situação de igualdade, cada qual com seus respectivos ônus, obrigações, faculdades e deveres, conforme previamente distribuído pela lei em abstrato. Nessa hipótese, imaginando-se uma situação ideal, a gangorra encontra-se na posição horizontal, perfeitamente equilibrada.

125 ARTUR CARPES define a função subjetiva do ônus da prova como uma técnica de "estruturação da atividade probatória das partes" (Ônus dinâmico da prova. Porto Alegre: Livraria do Advogado, 2010. p.71).

126 Vide Capítulos 4 e 5, nos quais tratamos, respectivamente, da técnica atualmente existente no Código de Defesa do Consumidor e da proposta de aplicação da chamada distribuição dinâmica do ônus da prova. 
Há situações, entretanto, em que esse equilíbrio não se mostra presente, e o ônus de uma das partes "pesa" mais que o ônus da parte contrária, de modo que a gangorra fica na diagonal - parte mais "frágil" (com mais "peso") na ponta de baixo e parte mais "forte" (com menos "peso") na ponta de cima.

Para restabelecer o equilíbrio desejado, o magistrado, por meio da função subjetiva do ônus da prova, desloca "horizontalmente" parcialmente o ônus da parte mais frágil para a parte mais forte, a qual se torna mais onerada que originalmente (recebe mais ônus do que previsto na lei em abstrato), mas, em compensação, a gangorra volta para a posição horizontal de equilíbrio. Retornaremos ao tema quando tratarmos especificamente das técnicas dinâmicas de distribuição do ônus da prova.

\subsubsection{Função objetiva do ônus da prova}

Não obstante os esforços das partes em cumprir seus respectivos ônus ou mesmo os do juiz, pela aplicação dos seus poderes instrutórios, para a obtenção dos esclarecimentos necessários às questões de fato pendentes de prova, pode-se chegar ao final do processo sem que o material probatório colhido seja suficiente para que o juiz forme o seu convencimento quanto às alegações de fato, ou seja, inexiste certeza ou probabilidade para um julgamento de mérito calcado nos efeitos jurídicos das alegações de uma das partes.

Diante de tal situação, o juiz, como condição inerente à própria atividade jurisdicional que exerce (e da vedação de proferir o non liquet), deverá valer-se da regra de distribuição do ônus da prova para saber quais alegações de fato deixaram de ser provadas e a quem cabia o ônus de prová-las (ou seja, o que deveria ter sido provado e qual das partes deixou de fazê-lo ou o fez de forma insuficiente), impondo a essa parte uma sentença desfavorável, pelo não cumprimento do seu mister. ${ }^{127}$

127 Para PONTES DE MIRANDA, “o ônus da prova, objetivo, regula a consequência de não se haver produzido prova. Em verdade, as regras sobre as consequências da falta da prova exaurem a teoria do ônus da prova. E falta prova, é que se tem de pensar em se determinar em quem se carga a prova. $\mathrm{O}$ problema da carga ou do ônus da prova é, portanto, o de determinar-se a quem vão as consequências de se não haver provado" (Comentários..., cit., t. 4, p. 271). 
Frise-se: devem ter sido esgotados todos os meios legítimos e lícitos de obtenção da prova, seja por meio das partes, terceiros ou do juiz, restando dúvidas consistentes sobre a veracidade ou não veracidade das alegações de fato formuladas pelas partes, por ausência ou insuficiência de provas, que levam ao mesmo resultado: o estado de dúvida.

Essa é a função objetiva do ônus da prova, como técnica para o magistrado pôr fim à demanda (regra de julgamento), ou seja, para dar uma solução final mesmo quando se encontrar diante da ausência ou insuficiência de elementos probatórios para formação do seu convencimento sobre qual parte tem razão naquele caso específico. ${ }^{128}$

Como adverte ROSENBERG, as normas que definem o aspecto objetivo do ônus da prova

[...] ajudam o juiz a formar um juízo, afirmativo ou negativo, sobre a pretensão que se faz valer, apesar da incerteza com relação às circunstâncias de fato, porque lhe indicam o modo de chegar a uma decisão em semelhante caso. A essência e o valor das normas sobre o ônus da prova consistem nesta instrução dada ao juiz acerca do conteúdo da sentença que deve pronunciar, em caso em que não se pode comprovar a verdade de uma afirmação de fato importante. A decisão deve ser emitida contra a parte sobre a qual recai o ônus da prova com relação à afirmação de fato não provado [...]. ${ }^{129}$

Ainda que a matéria probatória fique parcialmente esclarecida, mas prevaleça o estado de dúvida sobre uma alegação de fato relevante para o julgamento, o juiz deve utilizar a técnica da distribuição do ônus da prova para julgar, decidindo contra a parte a quem incumbia o ônus da prova de tal alegação de fato.

Trata-se de situação excepcional, como aponta BARBOSA MOREIRA, aplicável apenas na hipótese de ausência ou insuficiência de prova, e é uma "tragédia psicológica para qualquer juiz de sensibilidade apurada". ${ }^{130}$

128 De acordo com a lição de BARBOSA MOREIRA, o ônus como regra de julgamento somente interessa na fase decisória, e não na fase instrutória (Julgamento..., cit., p. 75-76).

129 Tradução nossa. No original: “[...] ayudan al juez a formarse un juicio, afirmativo o negativo, sobre la pretensión que se hace valer, no obstante la incertidumbre con respecto a las circunstancias de hecho, porque le indican el modo de llegar a una decisión en semejante caso. La esencia y el valor de las normas sobre la carga de la prueba consisten en esta instrucción dada al juez acerca del contenido de la sentencia que debe pronunciar, en el caso en que no puede comprobarse la verdad de una afirmación de hecho importante, La decisión debe dictarse en contra de la parte sobre la que recae la carga de la prueba con respecto a la afirmación de hecho no aclarada" (La carga ..., cit., p. 17).

130 O juiz..., cit., p. 182. Ainda de acordo com o referido autor, "o juiz não deve se preocupar com as regras legais de distribuição do ônus da prova, a não ser no momento de sentenciar. Aí então, verificando que determinado fato não foi provado ele terá de imputar a alguém as consequências 
Como o magistrado não pode se abster de dar uma solução à lide, diante da vedação ao non liquet, mesmo que não tenha formado seu convencimento quanto à veracidade ou não veracidade das alegações de fato que sustentam as pretensões das partes, o sistema deve prever uma regra clara e objetiva para que o litígio seja resolvido definitivamente. $^{131}$

Diante de tal circunstância, deve o magistrado examinar em relação a qual ou quais questão(ões) fática(s) essencial(is) para o julgamento do processo ${ }^{132} \mathrm{o}$ instrumento probatório foi inexistente ou insuficiente, e com base na regra de distribuição do ônus da prova (estática ou dinâmica) verificar a quem incumbia o ônus da produção dessa prova para lhe impor a derrota na demanda.

Caso ambas as partes tenham sido incapazes de fornecer a prova das respectivas alegações de fato e houver dúvida em relação a ambas, ainda assim o processo deverá ter um fim, com base na ordem de distribuição do ônus da prova, que, de acordo com o artigo 333 do Código de Processo Civil, atribui primeiro ao autor o ônus da prova, somente cogitando-se da aplicação da regra de juízo em relação ao réu na hipótese de o autor já ter se desincumbido por completo do seu ônus da prova.

Logo, na situação relatada supra (dúvida em relação às alegações de ambas as partes), a ação deve ser julgada improcedente, pois quem primeiro deveria superar o ônus da prova era o autor.

Para Giovanni Verde, a função objetiva dá o critério (necessário) para o julgamento diante do estado de dúvida. Trata-se, segundo o autor italiano, de uma

desfavoráveis da falta de prova daquele fato; eis aí para que servem as regras sobre a distribuição do ônus da prova. Se ele verifica que o fato não provado era o constitutivo, atribui ao autor as consequências nefastas dessa lacuna probatória. Se ele verifica que a prova faltante é de fato impeditivo, modificativo ou instintivo, quem suportará as conseqüências melancólicas será o réu" (O juiz..., cit., p. 180).

131 Não é demais lembrar que em tempos passados a solução do conflito era muitas vezes dada com base nas mais diversas maneiras, completamente irracionais aos nossos olhos, mas que em certo momento histórico e determinada região podiam fazer sentido, como as ordálias, os duelos e os juramentos (KNIJNIK, Danilo. A prova nos juízos cível, penal e tributário. Rio de Janeiro: Forense, 2007. p. 34). Infelizmente não dispomos de espaço para discorrer sobre esses curiosos meios de solução de conflitos, mas remetemos o leitor para a obra de MOACYR AMARAL SANTOS, em que expõe toda a evolução desses mecanismos (Prova..., cit., v. 1, p. 23-44).

132 A questão de fato sobre a qual paira o estado de dúvida deve ser crucial para a definição, pois, se por outros meios o magistrado conseguir formar seu convencimento, não será a hipótese de se aplicar a regra de distribuição do ônus da prova, mas de valoração do conteúdo probatório. 
demonstração do monopólio estatal do poder jurisdicional, que não permite a abstenção do magistrado em julgar a lide, o que equivaleria à sua rejeição, diante da manutenção do mesmo estado das coisas anterior ao processo, não podendo o sistema admitir que o juiz considere provados determinados fatos quando efetivamente não o foram ${ }^{133}$.

O que se procura evitar com a regra de juízo é que o juiz escolha livremente quem terá êxito e quem sairá derrotado na ação, a seu livre critério, atribuindo os respectivos ônus probatórios conforme a sua vontade.

Como adverte FLÁVIO LUIZ YARSHELL, “sob o ângulo objetivo, a regra encerra uma garantia contra o arbítrio, ao traçar um parâmetro racional para o julgamento diante do estado de ignorância acerca dos fatos". ${ }^{134}$

Entretanto, ainda que seja um fim inevitável, para obtenção da pacificação e demonstração do poder estatal (escopos social e político da jurisdição), na perspectiva colaborativa e democrática do processo, a função objetiva deve ser combatida para que, tanto quanto possível, os julgamentos sejam calcados em um juízo de certeza e o mais próximo da verdade, com a concessão de uma tutela aos jurisdicionados conforme determina o direito material (escopo jurídico da jurisdição), mais justa e eficaz.

Daí por que, sem afastar por completo a função objetiva (o que seria mesmo impossível), sustentamos uma reorganização da instrução probatória, com a valorização da função subjetiva do ônus da prova e com o emprego de técnicas de facilitação na obtenção da prova, com a distribuição dinâmica do ônus da prova, entre outras, como veremos nos Capítulos 4, 5 e 6, a seguir.

\subsubsection{Conclusão deste capítulo: prevalência da função subjetiva como técnica de descoberta da verdade}

Nos últimos anos, a tendência observada na doutrina foi a de se privilegiar a função objetiva do ônus da prova, tratando-a como verdadeira "essência" do fenômeno,

\footnotetext{
133 L'onere della prova nel proceso civile. Napoli: Jovene, 1974. p. 26-27.

134 Antecipação..., cit., p. 57.
} 
sobretudo depois da maior aceitação dos poderes instrutórios do juiz, de modo que perderia relevância definir durante a fase instrutória quem deveria produzir a prova, devendo o juiz se preocupar com sua substância e qualidade, ainda que em certas circunstâncias o juiz tenha que decidir com base na regra de distribuição do ônus da prova. ${ }^{135}$

Diante desse quadro, BEDAQUE questiona se o tema do ônus da prova não seria um "falso problema", pois não importaria saber a quem cabe provar, mas o que deve ser provado, ${ }^{136}$ circunstância a ser apreciada pelo juiz apenas no momento do julgamento, quando, enfim, poderá ser imposta a respectiva sanção. ${ }^{137}$

Em que pese nossa simpatia pela tese de ampliação dos poderes instrutórios do juiz, sustentada por BEDAQUE, parece-nos que o "problema" do ônus da prova é inafastável em um sistema que, em regra, não admite o non liquet e em que se vem admitindo, cada vez com maior frequência, a definição da atribuição dos ônus probatórios de maneira diferenciada, flexibilizando, no curso do processo, a regra abstrata de distribuição do ônus prevista na lei, embora concordemos que, com a ampliação dos poderes do juiz, os julgamentos fundamentados na regra de distribuição do ônus da prova tendam a ser cada vez mais esporádicos. ${ }^{138}$

135 A doutrina de Luiz EduARDo BoAventura Pacífico, embasada em lições de autores nacionais e estrangeiros ressalta essa visão prevalente do ônus objetivo da prova, mas adverte sobre a persistência do ônus subjetivo como regra de conduta para as partes. Nas palavras do aludido autor, "embora a regra de julgamento constitua a essência do fenômeno, os riscos da insuficiência de provas para a formação de convicção judicial projetam-se sobre as partes, estimulando-as à produção" $(O$ ônus..., cit., p. 163).

136 Nas palavras de aludido autor, “[...] não seria o chamado ônus da prova um falso problema? A prova recai sobre o fato, que pode ser constitutivo, modificativo, impeditivo ou extintivo do direito. Não importa, assim, saber a quem compete provar, mas o que deve ser provado" (Poderes..., cit., p. 124125 , grifos do autor).

137 Ainda segundo BEDAQUE, a regra do artigo 333 do Código de Processo Civil somente é aplicável no momento de proferir a sentença e não haveria razão para se vincular o ônus da prova à legitimidade para a produção da prova, pois inexiste correlação entre quem produz a prova e quem deveria tê-la produzido, em face do princípio da comunhão das provas, já analisado no item "1.1", supra (Poderes..., cit., p. 129). Concordamos com esse posicionamento, mas o enfoque que estamos procurando dar ao aspecto subjetivo do ônus da prova é outro: não se trata realmente de definir legitimidade da produção probatória (afinal a prova sempre poderá ser trazida por qualquer das partes, por terceiros ou mesmo pelo juiz), mas de se trabalhar a distribuição desse ônus subjetivo como técnica de incremento da busca da verdade, atuando paralelamente aos poderes instrutórios do juiz e ao dever de colaboração das partes.

138 Posicionando-se nesse sentido, ECHANDía considera que "a iniciativa do juiz e a liberdade de apreciação do material probatório podem diminuir a frequência de aplicação do ônus da prova, porém não sua importância" (Teoria..., cit., t. 1, p. 450). GIOVANNI VERDE também entende que, mesmo em sistemas marcados por amplos poderes instrutórios em relação ao juiz, a regra de distribuição do ônus da prova é relevante, embora reconheça que nesses sistemas serão cada vez mais raras as sentenças que julgam exclusivamente com base na regra de distribuição do ônus (L'onere..., cit., p. 44). 
Ainda que o juiz possa determinar a realização de provas de ofício, em determinadas circunstâncias ele simplesmente não tem condições de saber quais provas são necessárias para ao aclaramento dos fatos, e em outras dependerá exclusivamente da colaboração das partes para que sua produção possa se concretizar, de modo que tratar o ônus da prova apenas como uma regra de julgamento não contribui em nada para a plena satisfação da tutela jurisdicional. ${ }^{139}$

Nesse sentido, VitTORIO DENTI observa que a partir da perspectiva objetiva não se pode mesmo procurar compreender o problema da inversão judicial do ônus da prova e, pois, da repartição dinâmica do encargo de provar. ${ }^{140}$

Não podemos nos olvidar, ainda, que o processo é um conflito de interesses, em que as partes somente adotam determinadas medidas quando sabedoras que eventual omissão pode prejudicar a obtenção das respectivas pretensões (as partes agem, em regra, apenas segundo os seus próprios interesses), de forma que, se não houver um "incentivo" 141 por parte do magistrado apontando a quem incumbe determinada prova e os riscos da não desincumbência, dificilmente o conteúdo da prova surgirá espontaneamente para o juiz.

A nosso ver, o emprego da distribuição do ônus probatório como técnica de estruturação da prova, vinculada a um modelo abstrato, mas que seja "permeável” e "flexível" quando verificadas desigualdades nas capacidades probatórias das partes, a ponto de inviabilizar o acesso de uma das partes à prova, e, assim, à tutela jurisdicional no caso concreto, é primordial para que o conflito possa ser decidido com base em um juízo de certeza, capaz de eliminar a controvérsia de forma a se atender adequadamente aos escopos jurídico, social e político do processo.

139 Afinal, o julgamento com base na regra de distribuição do ônus da prova não garante a tutela a quem tem razão, mas contra quem deixou de se desincumbir de um ônus processual e, eventualmente, poderia ser verdadeiramente o titular do direito pleiteado ou resistido, mas que, devido à sua inércia, não conseguiu convencer o julgador.

140 L'inversione dell'onere della prova: rilievi introduttivi. Rivista Trimestrale di Diritto e Procedura Civile, Milano: Giuffrè, v. 46, n. 3, p. 709, sett. 1992. ANDREA PROTO PISANI também sustenta a persistência da função subjetiva, mesmo com o incremento dos poderes instrutórios do juiz (Lezioni di diritto processuale civile. 4. ed. Napoli: Jovene, 2002. p. 440).

141 A finalidade primária da instrução probatória é a descoberta dos fatos controvertidos, para a solução do conflito conforme aquilo que realmente ocorreu, e não a imposição de sanções pelo não cumprimento de um ônus. Dessa forma, o juiz deve forçar a produção probatória exatamente para reduzir a possibilidade de ter que decidir com fundamento na regra de julgamento, pois o processo deve ser concluído, tanto quanto possível, com base em um juízo de certeza (convicção). 
Portanto, em um sistema processual preocupado com a concessão de uma tutela jurisdicional équa e justa, entendemos ser primordial que o magistrado cumpra e faça cumprir com rigor a função subjetiva do ônus da prova, organizando a fase instrutória do processo mediante a adequada definição das questões fáticas a serem objeto de prova, com a indicação dos respectivos ônus probatórios às partes, e, quando viável, dos meios de prova pertinentes, ou, quando necessário "reequilibrar" as forças das partes litigantes, valer-se de técnicas excepcionais, como a distribuição dinâmica do ônus da prova, deslocando o ônus de uma parte a outra, sempre no intuito de suprir eventuais diferenças entre as partes e obter a convicção plena sobre os fatos relevantes debatidos. 


\section{CAPÍTULO 3 \\ DISTRIBUIÇÃO DO ÔNUS DA PROVA}

\subsection{Fundamentos para a distribuição do ônus da prova}

Fixados os conceitos de "ônus" e "ônus da prova", e estabelecidas as funções do ônus da prova no processo, é preciso fixar critérios que permitam que esse ônus processual e essas funções sejam adequadamente desenvolvidos, tanto para o aperfeiçoamento da instrução probatória (função subjetiva) como para a imposição dos efeitos negativos em caso de persistência do estado de dúvida (função objetiva). ${ }^{142}$

Como afirma CARnElutTI, "teoricamente, a eleição da forma de distribuir o ônus da prova entre as partes pode se basear em qualquer critério", mas é necessário que o sistema processual defina por meio de uma norma "a parte que tem interesse na existência e a parte que tem interesse na inexistência do fato". ${ }^{143}$

Ainda que, como já vimos, vigore entre nós o princípio da "comunhão das provas", ${ }^{144}$ segundo o qual as provas pertencem ao processo, sendo irrelevante saber qual parte trouxe a prova ao processo, as provas não são produzidas de modo desordenado ou conforme a vontade do juiz. Existem critérios objetivos de distribuição dos ônus probatórios às partes, guiados pela linha mestra dos interesses das partes no resultado do

142 A par do que sustentamos no Capítulo anterior, dando conta de que o ônus da prova deve ser priorizado pelo seu aspecto subjetivo, como uma técnica de organização da produção probatória, não podemos ignorar que a razão final de o sistema processual estabelecer a distribuição do ônus da prova decorre da indeclinabilidade da jurisdição, ou seja, uma vez instaurado o processo, o juiz não pode deixar de decidir sob o fundamento de insuficiência de provas ou contrariedade insuperável no instrumento probatório.

143 La prueba ..., cit., p. 14.

144 Também denominado "princípio da aquisição da prova", que, nas palavras de CASSIO SCARPINELLA BUENO, equivale a dizer que "a prova, porque destinada ao juízo e ao próprio juiz, deve ser considerada, analisada e avaliada independentemente de quem a produziu em juízo e, em última análise, pode, até mesmo, acabar por prejudicar quem a trouxe para o plano do processo, isto é, quem a produziu. Trata-se de princípio segundo o qual é irrelevante quem tenha sido aquele que produziu a prova em juízo que passa a pertencer ao próprio processo, longe da disponibilidade ou dos interesses das partes ou de eventuais terceiros" (Curso sistematizado de direito processual civil: procedimento comum: ordinário e sumário. 7. ed. São Paulo: Saraiva, 2014. v. 2, t. I, p. 254). O projeto do novo Código de Processo Civil consagra o princípio no artigo 368, nos seguintes termos: "O juiz apreciará a prova constante dos autos, independentemente do sujeito que a tiver promovido, e indicará na decisão as razões da formação de seu convencimento". Disponível em: <http://www.senado.gov.br /atividade/materia/getPDF.asp?t=157884\&tp=1>. Acesso em: $10 \mathrm{dez} .2014$. 
processo, assim como é preciso ter uma regra para dar uma solução ao litígio mesmo em caso de ausência ou insuficiência de provas.

Pela técnica de distribuição do ônus da prova é que se define a quem incumbe o ônus da prova e quem irá sofrer as consequências pela não comprovação de determinada alegação de fato.

O estabelecimento de uma regra de distribuição dos ônus probatórios das partes se impõe diante da inafastabilidade do julgamento, ${ }^{145}$ para que a jurisdição exerça suas funções e atinja os seus escopos.

Certamente, a partir do momento em que se consolidam os sistemas processuais que não admitem o non liquet, a existência de uma regra de distribuição do ônus da prova, em especial como uma regra de julgamento para os casos em que a instrução probatória seja insuficiente ou inexistente, persistindo o estado de dúvida do juiz, torna-se algo imprescindível para o próprio exercício da jurisdição e a administração da justiça.

Da mesma forma, a regra de distribuição deve existir para que as partes tenham conhecimento prévio dos riscos que correm na hipótese de não conseguirem provar e convencer o julgador acerca das alegações de fato cujo ônus lhes incumbe. ${ }^{146}$

Como ressalta Rosenberg, as regras sobre distribuição do ônus da prova devem ser predefinidas e objetivas, pois não se deveria deixar ao subjetivismo do juiz

145 Essa obrigatoriedade decorre da impossibilidade de o juiz pronunciar o non liquet, a qual é corroborada pela disposição contida no artigo 126 do Código de Processo Civil, advertindo que o juiz não pode se eximir de sentenciar sob a alegação de lacuna ou obscuridade da lei, devendo essa regra ser interpretada extensivamente como obrigatoriedade de o juiz julgar diante de qualquer lacuna ou obscuridade do processo.

146 GIOVANNI VERDE adverte sobre o risco de decisões irracionais e arbitrárias na solução de demandas em caso de insuficiência de provas quando o sistema não prevê uma regra de distribuição do ônus para esta hipótese (L'onere..., cit., p. 40-41). E continua o mencionado autor, advertindo que "ma non faremo grossi passi avanti, se lasciassimo alla discrezionalità assoluta del giudice al scelta tra la maniera di configurare il fatto al positivo o al negativo, e quindi, di gravare l'una o l'altra parte, secondo il suo arbitrio e la sua 'intuizione', delle conseguenze sfavorevoli della mancata prova di esso [...] una scelta del tipo sopra menzionato non può essere lasciata al giduice, ma deve essergli predeterminata in via normativa" (L'onere..., cit., p. 45-46). 
estabelecer qual parte será apenada pela ausência ou insuficiência da prova, sob o risco de ferir a segurança jurídica. ${ }^{147}$

Entretanto, como veremos adiante, ainda que tenhamos uma regra geral e abstrata de distribuição do ônus da prova, nada impede que os outros critérios objetivos, avaliados casualmente, permitam o deslocamento do ônus de uma parte à outra.

É oportuno destacar, desde já, que todos os critérios de distribuição, salvo o modelo dinâmico e o modelo que atribui todo o ônus da prova ao autor, têm o mesmo núcleo essencial, que é o interesse, ou seja, o elemento comum aos demais modelos é o interesse de cada uma das partes no processo, o qual é inferido, essencialmente, a partir das alegações de fato que as partes formulam. ${ }^{148}$

Assim, em regra, cada parte tem o ônus de provar os fatos constitutivos da sua pretensão. O que diferencia os diversos modelos de distribuição do ônus da prova que estudaremos a seguir é a fixação dos limites entre as provas que incumbem a cada uma das partes.

Antes de examinarmos esses critérios, porém, é preciso tecer algumas breves considerações sobre o(s) fundamento(s) de atribuir às partes o ônus de provar as alegações de fato controvertidas, para que, em seguida, possamos entender o papel da capacidade probatória na distribuição estática e na distribuição dinâmica do ônus da prova, pilar da técnica em estudo.

147 Nas palavras de ROSENBERG, “[...] a questão de saber qual das partes deve arcar com a consequência desfavorável de falta de prova de uma afirmação controvertida de um fato importante exige uma resposta baseada em uma regra de direito fixa, abstrata. A ciência não pode nem deve deixar de buscar esta regra; a prática tem necessidade dela e exige da ciência que a procure" (La carga..., cit., p. 122; tradução livre).

148 CARNELUTTI, Francesco. La prueba..., cit., p. 14-15. As partes envolvidas em um litígio, para que tenham êxito, devem, inicialmente, narrar ao juiz as suas respectivas pretensões, expondo os fatos que as embasam e os efeitos jurídicos deles decorrentes (ônus da afirmação). Tais fatos, entretanto, comumente não são conhecidos do juiz e exprimem versões conflitivas, a necessitar a produção de provas de sua veracidade. Diante desse quadro de incerteza e da necessidade de se produzirem elementos de prova capazes de influenciar no convencimento do julgador, cada parte, interessada que a sua pretensão prevaleça, assume o ônus de provar as alegações de fato anteriormente formuladas, não porque seja o único interessado em provar (como vimos, o interesse é de ambas as partes, em sentido opostos), mas porque os critérios de distribuição do ônus da prova legalmente previstos assim determinam. 
De acordo com o critério de distribuição que se adote, os seus fundamentos podem sofrer algumas alterações, mas, não obstante as pequenas nuances, é possível extrairmos algumas características elementares a dar embasamento à distribuição do ônus da prova.

Entre os diversos fundamentos já utilizados pela doutrina para explicar a existência da distribuição do ônus da prova, um dos que mais se destacou, em especial no século XIX, foi o "princípio dispositivo", que atribuía às partes o poder de instauração e de desenvolvimento do processo, de sorte que também em relação às provas e respectivos ônus deveria prevalecer a disponibilidade das partes.

Todavia, o princípio dispositivo somente justifica parcialmente a existência de uma regra de distribuição do ônus da prova, porquanto apenas define que incumbe às partes o ônus de produzir as provas, mas deixa sem resposta o aspecto central da distribuição, qual seja quem tem o ônus de provar o quê. Ainda em desabono a esse "fundamento", hoje é assente que deve haver distribuição do ônus da prova mesmo em sistemas essencialmente inquisitivos, de forma que não seria a disponibilidade da prova o elemento caracterizador da distribuição. ${ }^{149}$

Também já se tentou justificar a necessidade de se distribuir o ônus da prova por conta da estrutura dialética do processo, ${ }^{150}$ pois espera-se que cada uma das partes apenas alegue os fatos que lhe sejam favoráveis e se oponha aos que lhe sejam contrários, surgindo, assim, para cada parte, o ônus da prova das alegações de fato que lhe são favoráveis.

Esse posicionamento, embora explique a necessidade da prova, não delimita quais os fatos favoráveis a cada uma das partes e de quem é o risco da ausência ou

149 Essa constatação é feita por GUSTAVO HENRIQUE RIGHI IVAHY BADARÓ, ao expor que, “mesmo nos sistemas em que vigora o princípio inquisitivo também denominado de livre investigação da prova, é necessário que haja regras de julgamento distribuindo o ônus da prova. Por outro lado, não pode ser aceita a vinculação direta do 'princípio dispositivo' com o ônus da prova, salvo se este for considerado apenas em seu aspecto subjetivo, o que representa uma visão parcial daquele fenômeno que, evidentemente, não satisfaz. [...] Tenha ou não o juiz poderes instrutórios, as regras sobre o ônus da prova, como regras de julgamento, não poderão deixar de existir. Não há, em consequência, uma relação de implicação necessária entre regras sobre ônus da prova e princípio dispositivo" ( $O$ ônus da prova no processo penal. São Paulo: RT, 2003. p. 191-192). 
insuficiência da prova, razão pela qual não deve ser acolhido como o fundamento para a distribuição do ônus da prova.

Outros autores tentaram justificar na lógica ou na "natureza das coisas"151 a razão para se distribuir o ônus da prova, contudo esses não são institutos capazes de, isoladamente, fundamentar a distribuição.

Todo critério de distribuição pode conter uma lógica que o justifique, mesmo que seja para atribuir todo o ônus da prova ao réu, ou exclusivamente ao autor, de forma que não seria a lógica o elemento essencial para a distribuição, embora não se negue que a lógica faça parte de todos os critérios que examinaremos a seguir.

Nem mesmo a "natureza das coisas", comumente confundida com a "justiça", é capaz de distinguir quais fatos incumbem ao autor provar e quais incumbem ao réu, uma vez que não se trata de examinar subjetivamente como as coisas normalmente se passam. É preciso, antes de tudo, que a distribuição tenha um embasamento em elementos objetivos para que não se desvirtue. ${ }^{152}$

Assim, para a fundamentação da distribuição do ônus da prova, é preciso a associação de alguns elementos, que, em conjunto, dão o adequado direcionamento da atribuição dos respectivos encargos probatórios para as partes, quais sejam: a lógica, ${ }^{153}$ a justiça distributiva e a igualdade das partes. ${ }^{154}$

151 ROSENBERG, Leo. La carga..., cit., p. 119.

152 Como assevera ROSENBERG, a distribuição do ônus da prova deve ser regrada por uma norma geral e abstrata previamente estabelecida pelo legislador, e não à luz do exame do caso concreto e de acordo com o sentido subjetivo de justiça do juiz, pois isso acarretaria insegurança jurídica (La carga..., cit., p. 116). TARUFFO também ressalta o risco de se criar insegurança jurídica ao se atribuir ao juiz a possibilidade de modicar a distribuição do ônus da prova (O ônus como figura processual..., cit., p. 428-429).

153 CHIOvENDA não concorda que a lógica seja fundamento para a distribuição, não sendo simples dar uma justificativa "racional, absoluta e geral" para a distribuição do ônus da prova, pois, em determinadas circunstâncias, seria mesmo possível sustentar a atribuição de todo o ônus probatório a apenas uma das partes (Instituições..., cit., v. 2, p. 379). Mas tal circunstância, segundo o autor italiano, seria equivalente a negar ao autor a tutela jurídica, pois além de ter que provar os fatos constitutivos do seu direito, ainda teria que provar a não existência de fatos impeditivos ou extintivos (Op. cit., loc. cit.). De acordo com o mestre italiano, partindo-se da premissa de que as partes se encontram em iguais condições e de que o processo é regido pelo princípio dispositivo, a distribuição do ônus da prova deve ter por fundamento os critérios de "oportunidade" (interesse) e "igualdade", atribuindo os ônus às partes conforme os interesses buscados na ação e a disponibilidade de meios razoáveis para produzi-las (Instituições..., cit., v. 2, p. 379-380). CARNELUTTI critica a tese proposta 
A lógica e a justiça distributiva devem estar presentes porque a jurisdição deve ser "acessível" a todos, devendo o ônus da prova ser repartido entre as partes de forma "adequada" e "prudente", evitando-se a todo custo o modelo que atribui todo o ônus a apenas uma das partes, o que corresponderia à negação ao acesso à justiça, além de se mostrar antieconômico. ${ }^{155}$

$\mathrm{O}$ aspecto da igualdade também se mostra necessário, pois a ambas as partes deve ser assegurada ao menos a expectativa do êxito, distribuindo-se igualmente os riscos do processo e, consequentemente, da influência probatória, além de lhes atribuir igualdade de oportunidades de influir no convencimento do julgador e igualdade de tratamento pelo órgão judicial, que não se pode deixar influenciar por suas afinidades com uma das partes ou com seus interesses pessoais para julgar, ${ }^{156}$ daí a necessidade das regras de suspeição e impedimento para delegar o julgamento a outra pessoa, além de outras regras "formais" que direcionam o processo por um caminho de equidade entre as partes. ${ }^{157}$

por CHIOVENDA, considerando que o interesse sobre a prova de determinado fato, uma vez alegado, é de ambas as partes (de uma parte para provar a sua existência e da outra para provar a sua inexistência), devendo o critério da distribuição do ônus da prova se pautar pela posição das partes em relação aos fatos e o seu interesse na prova do fato alegado (La prueba..., cit., p. 14-15 e 219). Posteriormente, o citado autor reforça seu posicionamento, sintetizando que "[...] chi propone una pretesain guidizio deve provare i fatti, che la sorreggono; e chi oppone una eccezione deve dal suo canto provare i fatti, dai quali risulta; in altri termini chi pretende deve provare il fatto o i fatti constitutivi e chi eccepisce il fatto o i fatti extintivi come la condizione o le condizioni impeditive". (Sistema..., cit., v. 1, p. 425).

154 Como enfatiza ECHANDía, “[...] creemos que el fundamento de la carga de la prueba, como norma de distribución del riesgo de la falta de certeza (segundo aspecto de la noción), se encuentra en los principios de la lógica, la justicia distributiva y la igualdad de las partes ante la ley y el proceso, esto es, en la necesidad de darle a todas las partes una adecuada oportunidad y una guía segura para la defensa de sus derechos y de su libertad". (Teoria..., cit., p. 453). ROSENBERG, Leo. La carga..., cit., p. 114-115.

156 Nas palavras de BARBOSA MOREIRA, “[...] es indispensable, ante todo, que ambos litigante s puedan nutrir alguna esperanza de vencer; y, más aún, que puedan confiar en la ventaja práctica de la victoria. La igualdad de las partes se traduce aquí, en primer término, por igualdad de riesgos. [...]La exigencia de la igualdad de riesgos tiene corolarios de grande realce en lo que atañe a la carga de la prueba. [...] El órgano judicial necesita saber a cuál de los litigantes debe atribuir las consecuencias perjudiciales de la incertidumbre". (La igualdad de las partes en el proceso civil. Temas de direito processual: quarta série. São Paulo: Saraiva, 1989. p. 68-69).

157 ALFREDO BUZAID também sustenta que a equidade é um dos elementos definidores da regra de distribuição do ônus da prova, pois, em regra, autor e réu encontram-se em paridade no processo e têm condições de desenvolvê-lo em contraditório, não havendo justificativas para se atribuir o ônus a apenas uma das partes. Nas palavras do autor, "não nos parece suficiente, para explicar a repartição do ônus da prova, o dizer que foi instituída por uma razão de oportunidade, ou por uma regra de experiência, fundada no interesse à afirmação. O seu fundamento está, como demonstra WACH, em uma regra de eqüidade, que nasce da consideração que, litigando as partes e devendo conceder-se-lhe a palavra igualmente para o ataque e a defesa, é justo não impor só a uma o ônus da prova. Do autor não se pode exigir senão a prova dos fatos que criam especificamente o direito. Poderá o réu negar, mediante exceção, os pressupostos gerais desse estado (Do ônus..., cit., p. 63; grifos do autor). 
A ressalva que devemos fazer, contudo, é que o critério de distribuição não pode adotar a igualdade apenas formal, mas deve estar atento às desigualdades substanciais existentes entre as partes litigantes, o que, caso não diagnosticado e extirpado a tempo, com o emprego de técnicas de facilitação da prova, como, por exemplo, a distribuição dinâmica do ônus da prova, pode até mesmo inviabilizar o acesso à justiça a uma das partes.

\subsection{Capacidade probatória e prova diabólica}

Verificamos, no item precedente, que um dos fundamentos para que seja realizada a distribuição do ônus da prova entre as partes é a igualdade, princípio segundo o qual todos devem ser tratados da mesma forma no âmbito processual, sem qualquer tipo de discriminação, sendo-lhes garantida igualdade de oportunidades, igualdade de tratamento e igualdade de riscos, ou, como resume Hélio ToRnAGHI, "paridade de direitos, deveres, faculdades e encargos". 158

Essa "paridade" entre autor e réu no âmbito processual está consagrada no inciso I do artigo 125 do Código de Processo Civil, e de forma mais ampla na Constituição Federal, que em diversas oportunidades trata do assunto.

Em um processo ideal, em que as partes litigam em pé de igualdade, as regras formais de igualdade e de distribuição do ônus da prova (em sua forma estática) seriam suficientes para dar uma solução imparcial e justa ao litígio, visto que ambas recebem o mesmo tratamento, ambas exercem livremente as oportunidades que a lei lhes oferece, e ambas podem se desincumbir dos respectivos ônus sem maiores dificuldades (além daquelas que naturalmente o processo lhes impõe).

Ocorre que, na prática, existe uma infinidade de circunstâncias que influenciam as relações interpessoais, gerando um estado de desigualdade entre aqueles que se encontram em lados opostos numa relação jurídica e num processo, de modo que o equilíbrio presumido pelo sistema não se verifica no caso concreto, e a manutenção das 
regras de igualdade formal apenas serviriam para acentuar essa desigualdade, favorecendo, inevitavelmente, a parte que já se encontra em um estado de vantagem em relação à outra.

Os aspectos mais comuns de desigualdade são o econômico, o social e o cultural, muitas vezes acumulados, infelizmente, mais presentes em países como o nosso, em que os problemas estruturais ainda estão longe de uma solução.

Entretanto, como adverte BARBOSA MOREIRA, “a sorte do processo não pode depender de circunstâncias extraprocessuais", de modo que o sistema processual deve ser dotado de mecanismos compensatórios, “destinados, quando necessários, a equilibrar as possibilidades concretas das partes, e é um dever do juiz fazê-los atuar, em seu caso, tão eficazmente como possa". 159

Dentre os mecanismos compensatórios, a distribuição do ônus da prova pode exercer um importante papel, desde que o princípio da igualdade assuma outra "função", deixando de ser apenas o fundamento para a distribuição, para passar a ser utilizado como critério de atribuição dos respectivos ônus de provar ao autor e ao réu.

Com efeito, enquanto os modelos "estáticos" utilizam a igualdade como um pressuposto para a definição do ônus probatório de cada uma das partes, sem se preocupar se a igualdade realmente existe em sua faceta material, na técnica de distribuição dinâmica do ônus da prova, a igualdade (ou, melhor dizendo, a desigualdade na capacidade probatória das partes) é que determinará a oneração desta ou daquela parte no processo, atribuindo o ônus de provar certas alegações de fato à parte que se encontrar em uma situação de "vantagem".

Essa "vantagem" de uma das partes deve ser examinada, para fins de distribuição do ônus da prova, à luz da capacidade probatória das partes e da possibilidade de a prova ser produzida.

A capacidade probatória das partes consiste na efetiva possibilidade de se realizar a prova da alegação de fato controvertida, a partir dos meios probatórios

$159 \quad$ La igualdad..., cit., p. 74. 
existentes e dos conhecimentos tecnológicos e científicos revelados até o momento de sua realização.

Em regra, cada uma das partes é dotada de capacidade para produzir as provas pertinentes à demonstração da veracidade das alegações de fato que lhes sejam favoráveis. É mesmo intuitivo imaginar que faça parte da estratégia processual adotada pelos respectivos advogados invocar as questões fáticas favoráveis à tese sustentada pelo seu cliente e que possam ser por ele provadas, sobretudo diante da regra de distribuição do ônus da prova prevista no artigo 333 do Código de Processo Civil, ${ }^{160}$ que será examinada mais detidamente a seguir.

Parte-se da premissa de que as partes detêm capacidades probatórias iguais, como reflexo do princípio da igualdade de tratamento, oportunidade e riscos a que nos referimos anteriormente, sendo ofertados a ambas as partes os mesmos meios de prova (com as particularidades inerentes ao fato a ser provado) e a mesma possibilidade de influir no resultado do julgamento, sempre em observância ao contraditório e à ampla defesa.

O exame mais detido do caso concreto, à luz da visão instrumentalista e participativa do processo, em que o juiz exerce um diálogo direto com as partes e se aproxima da realidade que as envolve, contudo, pode apontar que, em virtude da posição de cada uma das partes em relação aos fatos a serem provados (intervenção direta ou indireta nos fatos ou sua ignorância), da posse da prova apenas por uma das partes ou da melhor disponibilidade da prova por uma das partes, ${ }^{161}$ a capacidade probatória da parte onerada da prova esteja comprometida, a ponto de ser extremamente difícil ou mesmo impossível a essa parte desincumbir-se do seu ônus. Por outro lado, a parte contrária revela ser dotada de plena capacidade para provar o fato contrário, ou seja, essa determinada parte se encontra em melhor posição para revelar a verdade sobre o fato, ${ }^{162}$ ainda que pelo

160 Essa possibilidade de se realizar a prova, contudo, pode sofrer variações de acordo com diversos elementos que interferem na condição da parte ou do fato a ser provado. Não obstante esta graduação, ainda que a prova a prova seja difícil, mas possível, dizemos que existe a capacidade probatória.

161 A melhor disponibilidade da prova pode decorrer de razões profissionais, técnicas, econômicas, fáticas ou jurídicas, conforme a natureza, complexidade e custos envolvidos para a realização da prova. Voltaremos ao tema no item "5.2.4" do Capítulo 5, a seguir, oportunidade em que indicaremos em relação a quais tipos a técnica dinâmica se aplica.

162 Para explicar a condição "privilegiada” da parte, SERGIO JOSÉ BARBERIO sustenta que "[...] en virtud del rol que desempeñó en el hecho generador de la controversia, por estar en posesión de la cosa o instrumento probatorio o por ser el único que 'dispone' de la prueba, etcétera, se encuentra en mejor 
caminho contrário (v.g., a parte onerada tinha que provar que certo fato ocorreu e seu adversário tem plena capacidade para provar que esse mesmo fato não ocorreu).

Em tal circunstância, em observância aos deveres de colaboração e lealdade que devem reger as condutas das partes litigantes, o juiz poderá determinar que a parte com maior capacidade probatória em relação a determinado fato faça a respectiva prova em seu favor (seja para provar que o fato ocorreu ou não ocorreu, que é verdadeiro ou falso), ainda que pela regra estática o ônus da prova de tal alegação de fato não lhe incumbisse originalmente.

Essa é a premissa essencial da técnica da distribuição dinâmica do ônus da prova: a extrema desigualdade quanto às possibilidades probatórias gera uma posição dominante ou decisiva de uma das partes diante da prova, ${ }^{163}$ a quem serão incumbidos o respectivo ônus e as consequências negativas da sua não desincumbência.

Como consequência, a regra abstrata de distribuição do ônus da prova, tal como a do aludido artigo 333 do Código de Processo Civil, deve ser mitigada. Dedicaremos todo o Capítulo 5 ao esmiuçamento da técnica da distribuição dinâmica do ônus da prova.

Não obstante a possibilidade de dinamização do ônus da prova, em determinadas circunstâncias a prova de determinada alegação de fato é simplesmente impossível, ${ }^{164}$ tanto para o autor como para o réu. Diz-se, então, tratar-se de uma prova

posición para revelar la verdad y su deber de colaboración se acentúa al punto de atribuirle una carga probatoria que, en principio, según las clásicas reglas que mencionamos más arriba, no tenía" [Cargas probatorias dinámicas. ¿Qué debe probar el que no puede probar? In: PEYRANO, Jorge Walter (Dir.); WHITE, Inés Lépori (Coord.). Cargas probatórias dinâmicas. Santa Fé: Rubinzal-Culzoni, 2008. p. $101]$.

163 A parte em condição de inferioridade deve estar impossibilitada ou em extrema dificuldade para poder invocar o uso da técnica de distribuição dinâmica do ônus da prova, pois lhe faltam condições "suficientes" de provar. Se a parte pode provar, não interessa que a outra também possa de forma mais fácil, pois não se enquadra na hipótese de prova "difícil" exigida pela técnica de distribuição dinâmica do ônus da prova. Nas palavras de SERGIO JOSÉ BARBERIO, “[...] quien pretenda beneficiarse con el desplazamiento de la carga probatoria hacia su contraria enrostrándole una mejor posición tendrá, asimismo, que justificar que él no está en condiciones - ni aun suficientes - de poder producirla. Visto de otro modo: si el sujeto puede probar, entonces tendrá que probar con independencia de que su contraria también pueda o mejor pueda" (Cargas..., cit., p. 104; grifos do autor).

164 Conforme leciona MOACYR AMARAL DOS SANTOS, "embora reais, verdadeiros ou possivelmente verdadeiros, fatos há, por sua natureza ou condições peculiares, impossíveis de provarem-se; outros, impossíveis de provarem-se por certos meios de prova" (Prova..., cit., v. 1, p. 230). 
diabólica, ${ }^{165}$ que, como veremos adiante, é uma das condicionantes para a aplicação da técnica de distribuição dinâmica do ônus da prova.

Prova diabólica ou probatio diabolica, nas palavras de ALEXANDRE FreITAS CÂMARA, é "a expressão que se encontra na doutrina para fazer referência àqueles casos em que a prova da veracidade da alegação a respeito de um fato é extremamente difícil, nenhum meio de prova sendo capaz de permitir tal demonstração". 166

Para que seja viável a distribuição do ônus da prova, portanto, é preciso que seja previamente examinada a possibilidade de a prova ser produzida, ou seja, não se tratar de uma hipótese de prova diabólica.

De fato, somente se justifica atribuir o ônus da prova a uma das partes se, na prática, essa alegação de fato puder ser realmente provada. Em caso negativo, não há que falar em ônus de provar, pois a parte onerada sequer teria a possibilidade de se desincumbir e sua pretensão estaria fadada ao insucesso.

Os modelos estáticos de distribuição do ônus da prova, contudo, não se preocupam com a possibilidade ou não de as alegações de fato serem provadas, ou mesmo com o grau de dificuldade que determinada prova exige da parte para ser produzida.

A consequência jurídica dessa omissão das regras estáticas de distribuição do ônus da prova é que, em determinadas circunstâncias, a impossibilidade ou extrema dificuldade de a parte se desincumbir do seu ônus probatório acarretará a negativa do acesso ao Poder Judiciário, por violação do direito à prova, "caracterizando, assim, violação oculta à garantia do acesso útil à justiça". ${ }^{167}$

\footnotetext{
165 A temática da prova diabólica é antiga, remontando ao direito romano "per formulas" e à ação publiciana, conforme relata DANILO KNIJNIK (A prova..., cit., p. 175).

166 Doenças preexistentes e ônus da prova: o problema da prova diabólica e uma possível solução. Revista Dialética de Direito Processual, São Paulo, v. 31, p. 12, 2005.

167 KNIJNIK, Danilo. A prova..., cit., p. 173. Com o mesmo entendimento, ARTUR CARPES ressalva que "[...] impor um ônus impossível de ser cumprido é o mesmo que vedar acesso à jurisdição: a tutela do direito, ou a possibilidade de sua negação pela parte ré, não será possível" (Ônus dinâmico..., cit., p. 90-91).
} 
Curiosamente, em nosso sistema processual, quando se regula a convenção das partes sobre a distribuição do ônus da prova, o inciso II do parágrafo único do artigo 333 do Código de Processo Civil declara nula a convenção que "tornar excessivamente difícil a uma parte o exercício do direito", de forma que, por uma interpretação restritiva, exclusivamente nessas hipóteses, o juiz poderia exercer um controle sobre a distribuição do ônus da prova, com base na excessiva dificuldade do exercício do direito. ${ }^{168}$

Para as demais hipóteses, ou seja, quando não existe convenção entre as partes sobre a distribuição do ônus probatório, "a incidência do art. 333 ostentar-se-ia inexorável e asséptica, porque de resolução em abstrato, sem consideração para o caso concreto". ${ }^{169}$

Como alternativa a essa situação de negativa de acesso à justiça, no modelo dinâmico de distribuição, a extrema dificuldade ou mesmo a impossibilidade de a parte produzir a prova, associada à maior capacidade probatória da parte contrária, ${ }^{170}$ prevê-se a possibilidade de deslocamento do ônus probatório, de modo que os fatos objeto da controvérsia possam ser mais bem elucidados e comprovados.

Caso a dificuldade na produção da prova seja igual para ambas as partes, não se trata de aplicar a técnica de distribuição dinâmica, mas sim a técnica de "redução do módulo de prova", que não se confunde com a função objetiva do ônus da prova, mas é incidente na fase de valoração da prova, admitindo-se para o julgamento do processo uma prova menos contundente do que aquela que seria normalmente exigida para o caso específico. $^{171}$

168 Voltaremos ao tema no item "6.4" do Capítulo 6, quando compararemos esse modelo de flexibilização da distribuição do ônus da prova com a técnica de dinamização da distribuição do ônus da prova.

169 DALL'AGNOL JUNIOR, Antonio Janyr. Distribuição dinâmica dos ônus probatórios. Revista dos Tribunais, São Paulo: RT, n. 788, p. 95, jun. 2001.

170 Por certo, se a parte inicialmente não onerada também se encontra em uma situação de dificuldade ou impossibilidade em produzir a prova contrária à alegação de fato da parte originalmente onerada, não será a hipótese de aplicação da técnica de dinamização, pois seu objetivo é o reequilíbrio da situação das partes, e não a atribuição de privilégios a uma delas (CARPES, Artur Thompsen. Ônus dinâmico..., cit., p. 91-95). DANILO KNIJNIK, por seu turno, observa que "o ônus dinâmico não pode ser aplicado para simplesmente compensar a inércia ou a inatividade processual do litigante inicialmente onerado, mas, única e tão somente, para evitar a formação da probatio diabólica diante da impossibilidade material que recai sobre uma das partes, à luz da natureza do fato e da sintaxe da norma" (A prova..., cit., p. 181). Sobre a vedação da prova diabólica inversa, vide item "5.3.2" do Capítulo 5 .

171 Sobre a distinção entre a técnica dinâmica e os standards probatórios dedicaremos o item "6.6" do Capítulo 6. 
Expostas essas considerações sobre a influência da capacidade probatória e a prova diabólica sobre a distribuição do ônus da prova, passemos agora à exposição dos diferentes critérios, desenvolvidos ao longo dos anos, para explicar a distribuição do ônus da prova até chegarmos ao modelo vigente no Código de Processo Civil, ${ }^{172}$ para, em seguida, explicarmos a sua insuficiência e introduzirmos a técnica de distribuição dinâmica do ônus da prova como mecanismo capaz de satisfazer os princípios e valores norteadores do processo civil moderno, ainda que de aplicação alternativa e subsidiária.

\subsection{Critérios "estáticos" de distribuição do ônus da prova}

Usaremos a denominação "estática" para definir as regras de distribuição do ônus da prova calcadas em premissas preestabelecidas, fixas, inflexíveis, gerais e abstratas, que não se alteram no curso do processo. Trata-se de uma forma de opor essas regras às técnicas denominadas "dinâmicas", que se caracterizam pela mutabilidade e pela possibilidade de deslocamentos dos ônus probatórios no curso do processo, desde que verificados determinados requisitos, estes sim preestabelecidos.

\subsection{1 Ônus da prova incumbe ao autor}

Uma interpretação incompleta das fontes romanas, em especial de máximas como onus probandi incumbit actori, necessitas probandi incumbit illi qui agit, ${ }^{173}$ e actori non probante, reus est absolvendus, fez com que alguns autores sustentassem no passado a atribuição do ônus probatório exclusivamente ao autor.

Em decorrência desses estudos, criou-se a (falsa) impressão de que vigorava no direito romano um sistema em que todo o ônus probatório incumbia ao autor, ou seja, além do ônus da prova dos fatos por ele alegados, cabia-lhe a prova da não ocorrência de fatos extintos, modificativos e/ou impeditivos.

\footnotetext{
172 Observados os estritos limites do presente trabalho, não temos a mínima pretensão de esgotar todas as técnicas sobre a distribuição do ônus da prova sustentadas nos mais diversos países (e nem seria adequado fazê-lo), mas procuraremos dar destaque aquelas comumente relacionadas pela doutrina que se debruçou sobre a matéria, traçando, assim, um panorama geral da evolução doutrinária.

173 Digesto, Marciano, 22, 3, 21: Verius esse existimo ipsum qui agit, id est legatarium, probare oportere scisse alienam rem vel obligatam legare defunctum, non heredem probare oportere ignorasse alienam vel obligatam, quia semper necessitas probandi incumbit illi qui agit.
} 
Esse equívoco, além de resultar em algo completamente ilógico e absurdo, decorre de uma tradução restritiva do verbo agit, atribuindo-lhe o sentido de agir (promover uma ação) e ao substantivo actori a significado de autor (aquele que promove a ação).

Como a ação era um ato promovido apenas e exclusivamente pelo demandante (é o autor quem age pedindo alguma coisa), todo o ônus probatório seria do autor. Ao demandado (réu) caberiam tão somente a negação e a defesa.

Entretanto, essa interpretação literal mostrou-se incompleta e incompreensível à luz do sistema e de outras máximas romanas, não inicialmente levadas em consideração por esses primeiros intérpretes.

Com efeito, o verbo agit deve ser interpretado com um significado muito mais amplo no âmbito processual, como "alegar algo em juízo" (causa de pedir e pedido, em termos atuais), e actori não é apenas quem promove a demanda, mas o titular da pretensão alegada.

Nesse sentido, não podemos olvidar das outras máximas romanas pertinentes ao ônus probatório, como "reus in excipiendo fit actor" e "reus in excipiendo actor est", ou seja, o demandado, quando excepciona (formula pretensões contrárias às pretensões do autor), age como autor ou, em outras palavras, é o titular da pretensão excipienda.

Diante dos diversos equívocos contidos nessa interpretação restritiva dos textos romanos, esse critério foi abandonado ainda na Idade Média, por força dos estudos da Escola de Bolonha, que propôs uma nova interpretação, conforme discorremos no item seguinte.

\subsection{2 Ônus incumbe à parte que afirma o fato, na ação ou na exceção, como autor ou réu}

Uma nova interpretação do direito romano, proposta pela Escola de Bolonha a partir dos estudos dos glosadores nos séculos XVI e XVII, levava em consideração a 
necessidade de ambas as partes (autor e réu) provarem os fatos que alegam ao agir em juízo, seja na ação ou na exceção.

Essa corrente parte da ideia fundamental de que quem invoca determinados fatos a seu favor deve prová-los para que possa sair vitorioso na demanda, seja na condição de autor, quando promove a ação e apresenta os fatos que fundamentam a sua pretensão, seja na condição de réu, quando excepciona e alega fatos que a sustentam. ${ }^{174}$

Trata-se, evidentemente, de uma interpretação mais lógica e sistemática dos textos romanos, em que o ônus da prova é repartido entre as partes, conforme os respectivos fatos alegados em seu favor.

O autor formula a ação e alega fatos que sustentam o seu pedido, logo, é ônus do autor a prova de tais fatos, sob o risco de ser-lhe imposta a derrota ("actore non probandi, reus est absolvendus").

Por outro lado, se o réu formula exceções fundadas em outros fatos e assim fazendo age como "autor" ("reus in excipendo fit actor"), ou seja, como titular de uma pretensão, forçoso concluir que o réu terá o ônus de provar os fatos alegados na exceção.

Esse critério, que vigorou por muitos anos no direito europeu continental, embora esteja em concordância com o princípio da igualdade que fundamenta a distribuição do ônus da prova, foi considerado extremamente genérico, incompleto e insuficiente para regular todas as situações processuais, ${ }^{175}$ razão pela qual não se mostra suficiente como critério geral.

De fato, a principal crítica formulada a esse critério de distribuição do ônus da prova consiste na indefinição dos fatos que precisariam ser provados (apenas os fatos

\footnotetext{
174 Essa será, como ficará evidenciado do estudo dos demais critérios, a tônica geral que rege a distribuição do ônus da prova, intimamente vinculada aos interesses perseguidos pelas partes no processo, atribuindo-se os respectivos ônus conforme as alegações que formulam e as pretensões que objetivam.

175 Como adverte CHIOvendA, "as fontes romanas inserem, a esse propósito, alguns textos que se perpetuaram como a base da doutrina do ônus da prova; mas, em verdade, não são, em si mesmos, muito completos", pois em muitos casos são "enunciados pelos textos em caso concreto, que, generalizados, nada significam” (Instituições..., cit., v. 2, p. 376-377).
} 
positivos ou também os negativos?) e a ordem da distribuição (quem é o primeiro onerado?), o que poderia levar à situação de as partes terem que provar todos os fatos alegados e também a inexistência de fatos impeditivos, modificativos e extintivos, o que, como visto no item precedente, levaria a um sistema injusto e ilógico.

Igualmente, esse critério não considera a possibilidade de existirem no processo alegações de fato que não necessitem de prova, como os incontroversos, os notórios e os presumidos, que, evidentemente, se não precisam ser provados por quem os alega, não implicam ônus para a parte que os afirma.

Ainda nesse modelo, fica indeterminado o ônus da prova dos fatos alegados no curso do processo (após a defesa do réu), em réplicas e tréplicas, que, corriqueiramente, surgem no trâmite processual e que também precisam ser regulados de modo que o ônus da prova cumpra sua dupla função.

Por tais razões, a doutrina rechaça esse modelo extraído das máximas romanas como regra geral de distribuição do ônus da prova, devendo ser agregados outros elementos de distinção na definição da atribuição do ônus probatório às partes, como veremos nos itens seguintes.

\subsection{3 Ônus da prova incumbe a quem afirma, não a quem nega}

Antes de adentrarmos nos critérios modernos de distribuição do ônus da prova, é relevante apresentarmos aquele, também fundado nas bases romanas, que atribui o ônus da prova não de acordo com a posição das partes no processo (autor ou réu), mas conforme o objeto da prova, quer se trate de uma afirmação ou de uma negação.

Segundo esse entendimento, apenas quem formula uma afirmação tem o ônus de prová-la, e as alegações de fatos negativos não necessitam ser provadas.

O embasamento teórico desse método está nas assertivas romanas ei incumbit probatio qui dicit, non qui negat, affirmanti non neganti incumbit probatio e negativa non sunt probanda. 
Ainda que como critério puro de distribuição do ônus da prova não tenha encontrado muitos defensores, é inconteste que a ideia de que as negativas não se provam permaneceu incrustada por muito tempo no pensamento jurídico de forma genérica. Somente com a posterior distinção entre alegações determinadas (negativas ou positivas) e alegações indeterminadas (negativas ou positivas) que a atribuição do ônus da prova das negativas (determinadas) se fortaleceu. ${ }^{176}$

As máximas romanas invocadas têm, em verdade, um significado distinto daquele que defendem a validade desse critério de distribuição do ônus da prova, pois a "negação" (negat, neganti e negativa) a que se referem é a oposição aos fatos alegados pela parte contrária, que tornam estes "pontos" de fato em "questões" de fato controversas. ${ }^{177}$

Assim, ao se tornarem controvertidos, os pontos alegados pelas partes necessitarão ser provados, e os textos romanos anteriormente citados indicam que essa prova é ônus da parte que formulou o ponto de fato, e não da parte que o impugnou com sua mera negação.

Ou seja, se uma parte simplesmente nega a alegação da parte contrária, essa alegação se tornará controvertida, a exigir sua prova, e o ônus dessa prova incumbirá a quem formulou a alegação, e não a quem a negou. Essa é a interpretação que se deve extrair dos textos romanos suprarreferidos.

176 Como explica ECHANDíA, "las negaciones definidas tienen por objeto hechos concretos, delimitados en tiempo y lugar (negativa coartata loco et tempore), que presuponen la existencia de otro hecho opuesto de igual naturaleza, el cual resulta afirmado implícita o indirectamente [...]; las negaciones indefinidas son aquellas que no implican la afirmación indirecta de otro hecho concreto, delimitado en tiempo y espacio [...]" (Teoría..., cit., t. 1, p. 211-212), concluindo que “[...] 8. ${ }^{\circ}$ las únicas negaciones que no exigen prueba son las sustanciales y las formales indefinidas de hecho, por la imposibilidad de suministrarla en razón de su carácter indefinido y no de la negación misma; 9. ${ }^{\circ}$ las demás negaciones se prueban demostrando el hecho positivo contrario, bien sea directamente o mediante indicios o inferencias de otros hechos, y por este motivo, tanto el demandante, cuando base en ellas sus pretensiones, como el demandado, cuando las alegue para sus excepciones, están sujetos a la carga de probarlas [...]" (Op. cit., p. 213).

177 Falar em questão controvertida é uma redundância, pois a questão já é o ponto que, em face da oposição da parte contrária, se tornou controvertido. Como assevera CARNELUTTI, "in quanto una affermazione, compressa nella ragione (dellapretesa o della contestazione), possa generare un dubbio e così debba essere verificata, diventa una questione. Perciò la questione si può definire un punto dubbio, di fatto o $\mathrm{d}$ i diritto, e la sua nozione è correlativa a quella di affermazione" (Sistema..., cit., v. 1, p. 353; grifos do autor). 
Além do equívoco de interpretação, também é possível se opor a esse critério, tal como formulado, com base em outros fundamentos. O mais evidente deles é que a formulação de uma afirmação ou de uma negação, em regra, não passa de um critério de redação, pois aquele que afirma (expressamente) simplesmente nega (implicitamente) o contrário, e quem nega (expressamente) também está afirmando (implicitamente) o oposto.

Por exemplo, se afirmarmos (expressamente) que os contratantes são agentes capazes, estamos, ao mesmo tempo, negando (implicitamente) que são incapazes. Logo, a natureza "afirmativa" ou "negativa" dos fatos não poderia ser o elemento diferenciador do ônus probatório, pois, comumente, é possível "afirmar negando" ou "negar afirmando".

Outrossim, a afirmação ou negação de um fato não altera a possibilidade de se produzir a prova dessa alegação. Não é possível afirmar que seja mais difícil produzir a prova de fato negativo do que de fato afirmativo. Essa dificuldade ou mesmo impossibilidade irá existir nas negações indeterminadas (v.g., nunca estive em determinado lugar), mas também nas afirmações indeterminadas (v.g., sempre compro alimentos no mesmo supermercado), de sorte que, mais uma vez, não será a natureza afirmativa ou negativa o elemento determinante para a distribuição do ônus da prova, mas a sua indeterminação, que, frisa-se, pode decorrer de uma afirmação ou de uma negação.

A indefinição de quais fatos afirmados devem ser provados é outra restrição que se impõe a esse mecanismo, pois, tal como apontado no item precedente, não são todos os fatos alegados (positivos ou negativos) que precisam ser provados, existindo no sistema regras que dispensam determinados fatos de serem provados.

Por fim, mesmo entre os autores que aparentemente acolhem esse critério, por exemplo, CARLO LESSONA ${ }^{178}$ e CARNELUTTI, ${ }^{179}$ ele nunca aparece de forma pura, ou seja,

178 Para o autor italiano, o principio do "onus probandi ei incumbit qui dicit" apresenta-se como "único, verdadeiro e justo", mas o associa ao critério da normalidade, a ser detidamente examinado no item "3.3.5", adiante, afirmando que "el que quiere hacer valer un derecho, debe probar sencillamente los hechos que, según la relación normal, engendran el derecho y reclaman la aplicación del preceptoregla; el que contradice el derecho, debe probar los hechos anormales que impiden su existencia y hacen aplicable el precepto-excepción" (Teoría general de la prueba en derecho civil. Tradução E. A. de Paz. Madrid: Reus, 1906. v. 1, p. 180 e 189-190).

179 "La experiencia en que se funda es que si un hecho existe, la parte que tiene interés en afirmarlo, en cuanto de él se le sigue un efecto jurídico favorable, consigue dar la prueba de él; por eso, si no se da la prueba, hay razón para considerarlo inexistente; la regla es, por tanto, en su fórmula más general, 
como único elemento determinante para a repartição do ônus da prova, de modo que não se mostra lógico e juridicamente correto utilizá-lo como único atributo para a distribuição do ônus probatório entre as partes.

\subsection{4 Ônus da prova incumbe ao autor e ao réu quanto aos fatos que fundamentam as suas pretensões}

Essa tese é uma variação do modelo exposto no item "3.3.2", com uma roupagem moderna, atribuindo o ônus da prova ao autor e ao réu, quanto aos fatos que cada qual alega em suas respectivas peças processuais.

De acordo com os defensores dessa corrente, em especial FRANCESCO RICCI, ${ }^{180}$ cada uma das partes, na ação ou na exceção, deve provar a existência ou inexistência dos fatos que sustentam as suas respectivas pretensões e sem os quais o juiz não pode acolher a ação ou a exceção.

O avanço em relação ao critério descrito no item "3.3.2", supra, consiste na oneração não apenas da parte que afirma um fato, mas também daquele que alegue a inexistência de um fato, superando, assim, a máxima de que as negativas não são provadas.

A par dessa evolução, as mesmas críticas formuladas no item "3.3.2" servem para o critério de distribuição do ônus da prova em exame, uma vez que deixa em aberto alguns pontos essenciais para que se possa estabelecer uma regra geral, como a indefinição dos fatos a serem provados (sempre lembrando que há fatos que não necessitam de prova por quem os alegou) e a restrição de distribuir o ônus de prova apenas quanto aos fatos alegados na petição inicial e/ou na defesa, sem considerar os outros fatos que podem ser alegados no curso do processo e que igualmente necessitam ser provados.

que la falta de certeza de un hecho perjudica a aquella de las partes que tiene interés en su afirmación y, por tanto, la falta de certeza del hecho constitutivo perjudica a quien hace valer el derecho, mientras que la falta de certeza del hecho extintivo o invalidativo perjudica a aquel contra quien se lo hace valer. De la aplicación de esta regla deriva un nuevo aspecto de la carga de la prueba, en el sentido de que cada una de las partes tiene que proponer la prueba de los hechos en cuya afirmación está interesada [...]" (Instituciones..., cit., v. 1, p. 347; grifos do autor).

180 " “...] quienquiera que sienta como base de su demanda o excepción, la afirmación o la negación de un hecho, está obligado a suministrar la prueba de la existencia o la no existencia del hecho, toda vez que, sin esta demostración, la demanda o la excepción no resulta fundada y el juez no puede admitir demandas o excepciones infundadas" (Tratado de las pruebas. Pamplona: Analecta, 2005. p. 88). 
Diante de tal quadro, esse critério também se mostra insuficiente para regular, de forma ampla e completa, todas as situações processuais em que é preciso definir a quem incumbe o ônus probatório, de modo que não pode ser admitido como uma regra geral pertinente.

\subsection{5 Ônus distribuído pela regra da normalidade}

De acordo com essa corrente, o ônus da prova incumbe a quem pretende demonstrar um fato anormal, pois os fatos normais se presumem, e, portanto, são isentos de prova.

Como adverte MALATESTA, existem dois princípios que sustentam a distribuição do ônus da prova pelo critério da normalidade: o ontológico (principal) e o lógico (acessório). ${ }^{181}$

Pelo princípio ontológico, decorrente do "modo natural de ser das coisas", “observando que uma coisa se verifica na maioria dos casos, o espírito humano, não conhecendo se ela se verifica ou não no caso particular, inclina-se, por um juízo de probabilidade, a crê-la verificada", de modo que, "apresentando-se, pois, duas afirmações opostas, uma ordinária, a outra extraordinária, a primeira presume-se verdadeira, a segunda deve ser provada". ${ }^{182}$

Já pelo princípio lógico, decorrente dos “meios de convicção do espírito humano", "na colisão entre um fato positivo e um fato negativo, quem afirma o fato positivo tem de prová-lo, com preferência a quem afirma o fato negativo", ${ }^{183}$ uma vez que

\footnotetext{
$181 \quad$ A lógica ..., cit., p. 137-138.

182 A lógica..., cit., p. 137. Embora o autor italiano escreva embasado no direito penal, diante do seu caráter "universal", sustenta o cabimento da distribuição do ônus da prova calcada no princípio ontológico mesmo no âmbito civil, asseverando que "o autor que impugna um direito gozado pelo demandado, o autor que pede judicialmente o reconhecimento e o cumprimento de uma obrigação, não faz mais que afirmar um estado de coisas contrário ao que está no curso ordinário, um estado de coisas extraordinário; e por isso cabe-lhe a prova, já que a presunção de ter razão assiste ao demandado [...]. Quando, pois, o autor reuniu as suas provas em apoio às suas asserções, o demandado, que em contradição emite uma simples asserção, não faz mais que contrapor uma asserção não provada, a uma asserção provada; e como esta tem direito a ser tida por verdadeira de preferência à não provada, a presunção de verdade sendo nêste segundo momento a favor do autor, a obrigação da prova fica a cargo do demandado" (A lógica..., cit., p. 148).

A lógica..., cit., p. 138.
} 
os fatos positivos podem mais facilmente ser provados, por meio das provas diretas e/ou indiretas, enquanto os fatos negativos somente podem ser provados pela prova indireta.

No entanto, como se define a normalidade dos fatos alegados?

$\mathrm{O}$ elemento essencial diferenciador entre o normal e o anormal é a continuidade das situações jurídicas, que se presumem persistir até que se prove a ocorrência de outro fato capaz de extingui-las, modificá-las ou impedi-las.

Segundo FranÇOIS GORPHE, não há necessidade de provar o que está de acordo com o estado normal e usual das coisas. ${ }^{184}$ Outros autores também adotam o critério da normalidade para determinar a quem incumbe o ônus da prova, como LESSONA ${ }^{185}$, associando o fato normal à regra geral e o fato anormal à regra excepcional, em complemento ao critério da afirmação exposto no item "3.3.3", supra.

Assim, deve ser considerado normal o exercício das liberdades, o cumprimento das leis e dos direitos alheios. Quando essa situação de normalidade se altera (v.g., descumprimento da lei ou violação de um direito alheio), a parte que invocar essa alteração da situação normal como fundamento da sua pretensão deve prová-la, e, assim o fazendo, presume-se que esse novo quadro se propaga e permanece estável, até que a parte contrária alegue e comprove uma nova alteração da situação jurídica, em decorrência de outro fato anormal, com eficácia extintiva, modificativa ou impeditiva da situação primitivamente anormal, mas que com a prova do autor se tornou normal.

A principal crítica direcionada ao critério da normalidade é o seu subjetivismo e vaguidade, pois nem sempre é fácil se diferenciar, "a priori”, a situação normal da situação anormal, atribuindo-se essa qualificação ao juiz, podendo variar de acordo com os seus valores políticos, econômicos, jurídicos, religiosos e morais, de modo que não poderia

\footnotetext{
184 De la apreciación de la prueba. Buenos Aires: Editorial Europea América, 1955. p. 158.

185 "La obligación de probar no está determinada por la cualidad del hecho que se ha de probar, sino por la condición jurídica que tiene en el juicio aquel que lo invoca. No importa, que la prueba pueda ser fácil para el demandado y difícil para el actor; si el hecho que se ha de probar constituye extremo de la acción, debe probarlo el actor y no el demandado" (Teoría..., cit., v. 1, p. 185; grifos do autor). "La segunda parte de la regla dice que corresponde al demandado la prueba del fundamento de su excepción" (Op. cit., p. 208).
} 
ser empregado como regra geral, senão como uma modalidade do critério da natureza dos fatos, que será exposto a seguir.

O próprio LESSONA admite essa indefinição do critério da normalidade quando a lei não expressa de forma clara e precisa uma regra geral e suas exceções, ${ }^{186}$ o que seria mesmo impossível para todas as situações da vida, de modo que o juiz deve se socorrer dos princípios racionais de lógica jurídica e outros gerais do direito para a adequada definição do ônus da prova a ser atribuído a cada uma das partes.

Para Michelli, o critério da normalidade é relevante para definição da distribuição do ônus da prova não como regra geral, mas como elemento de política legislativa, na definição das normas substantivas que regulam o caso concreto, atribuindo os respectivos ônus ou definindo presunções, pela definição das normas gerais e respectivas exceções. ${ }^{187}$

Ainda que o critério da normalidade tenha limitações, diante das abstrações e valorações pessoais possíveis de serem realizadas pelo juiz, por certo que, se examinado como complemento de outros critérios ou para definição de política legislativa, ganha relevância, sobretudo pelos avanços em relação aos critérios anteriores, reconhecendo que alguns fatos não necessitam ser provados e que os fatos a serem provados podem ser afirmativos ou negativos.

\subsection{6 Ônus da prova incumbe a quem pretende inovar}

À semelhança do modelo anterior, pelo critério da inovação, aquilo que segue seu curso natural deve ser presumido, e apenas o que se pretende alterar no mundo jurídico

186 Para o aludido autor, o critério da normalidade "tiene en si, como la de Pescatore, alguna vaguedad; la cual depende del hecho de que el criterio para distinguir la relación normal de hecho de la relación anormal no es un criterio que à priori se pueda determinar en forma general, ni pueda inferirse en todos los casos de las expresiones de la ley, sino que es un criterio que se debe buscar en los principios racionales de la lógica jurídica, y en los principios generales del derecho", concluindo que "preciso es reconocer que debe dejarse mucho à la natural elasticidad inquebrantable de las relaciones de la vida jurídica" (Teoría..., cit., v. 1, p. 190).

La carga..., cit., p. 301-305. 
deve ser provado, cabendo o respectivo ônus àquele que sustenta o fato inovador, pois quem pretende inovar uma situação jurídica quer tirá-la da sua normalidade.

O ônus da prova é atribuído a quem alega um fato que implique inovação da situação jurídica ou nega um fato que se considera existente.

Nas palavras de EDOUARD BONNIER, "aquele que quer inovar deve demonstrar que é fundada sua pretensão", ${ }^{188}$ ônus que deve ser atribuído inicialmente ao autor. Entretanto, se o réu em sua defesa alega um fato novo, também deve prová-lo, assim como se o autor alega outros fatos em sua réplica, cabendo-lhe o ônus da prova.

Em resumo, de acordo com o referido autor, "o que alega um fato novo contrário à posição adquirida por seu adversário, deve provar a verdade deste fato". ${ }^{189}$

As críticas formuladas no item precedente também se aplicam aqui, notadamente quanto à dificuldade de definir o que é inovação em determinadas circunstâncias, atribuindo-se ao juiz a tarefa de estabelecer tais fatos e, consequentemente, o ônus da prova de cada uma das partes, o que acarreta uma subjetividade na definição dos respectivos ônus probatórios das partes.

\subsection{7. Ônus distribuído pela regra da natureza dos fatos}

De acordo com o critério da natureza dos fatos, devem ser considerados dois elementos para a distribuição do ônus da prova: a posição das partes e a natureza dos fatos, atribuindo ao autor a prova dos fatos constitutivos da sua pretensão e ao réu a prova dos fatos impeditivos, modificativos e extintivos da pretensão do autor.

Trata-se do critério escolhido pelo legislador pátrio para distribuição do ônus da prova, conforme expresso no artigo 333, incisos I e II, do Código de Processo Civil e artigo 370, incisos I e II, do projeto do novo Código de Processo Civil. ${ }^{190}$

\footnotetext{
188 Tratado teorico y practico de la prueba en derecho civil y penal. Tradução Don J. V. Caravantes. Madrid: Reus, 1929. p. 42.

189 De la prueba ..., cit., p. 44.
} 
Para a exata compreensão desse modelo de distribuição do ônus da prova é preciso definir adequadamente no que consiste a natureza (ou eficácia) constitutiva dos fatos alegados pelo autor, bem como a natureza (ou eficácia) impeditiva, modificativa e extintiva dos fatos alegados pelo réu.

Para ChIOVENDA, é preciso, inicialmente, distinguir as condições de existência de uma relação jurídica: existem as condições específicas e as condições genéricas. Aquelas são próprias e essenciais de determinada relação e que lhe distingue de outras. Estas são comuns a outros negócios jurídicos. ${ }^{191}$

A alegação de fato com eficácia constitutiva a ser provada pelo autor restringese às condições específicas, que produzem determinados efeitos jurídicos (efeitos normalmente esperados) no interesse de quem os alega. Ao réu incumbe a prova das alegações de fato que formula e que tenham a eficácia de impedir a produção desses efeitos normais (fatos impeditivos) ou outros fatos posteriores que tenham a eficácia de extinguir ou modificar os efeitos pretendidos pelo autor (fatos extintivos e modificativos). ${ }^{192}$

A natureza constitutiva, portanto, está relacionada com a pretensão formulada, e não em relação ao efeito da tutela sobre a relação de direito material, ou seja, o fato é constitutivo do direito do autor quando constituir o fundamento da pretensão do autor e do resultado esperado da ação, ainda que esse resultado seja a extinção, impedimento ou modificação de uma relação jurídica.

Com efeito, em determinadas ações, a pretensão do autor pode ser o reconhecimento da extinção de determinada relação jurídica por vício de consentimento, por exemplo. Nesse caso, o elemento com eficácia constitutiva da sua pretensão será a demonstração do vício, para obter a extinção do negócio viciado (efeito pretendido com a propositura da ação).

\footnotetext{
190 Disponível em: <http://www.senado.gov.br/atividade/materia/getPDF.asp?t=157884\&tp=1>. Acesso em: 10 dez. 2014.

191 Instituições..., cit., v. 2, p. 381-382.

192 Nas palavras de CHIOvEnDA, “o autor deve provar os fatos constitutivos, isto é, os fatos que normalmente produzem determinados efeitos jurídicos; o réu deve provar os fatos impeditivos, isto é, a falta daqueles fatos que normalmente concorrem com os fatos constitutivos, falta que impede a estes produzir o efeito que lhes é natural" (Instituições..., cit., v. 2, p. 382).
} 
Não obstante o efeito extintivo pretendido pelo autor, em relação a este a demonstração do vício tem natureza constitutiva para a sua pretensão, ou seja, é o elemento que constitui e fundamenta o interesse do autor a ser tutelado.

Ao réu cabe a prova das alegações de fato que, se demonstradas, podem extinguir a pretensão do autor, impedir que a pretensão do autor produza os efeitos desejados por aquele, ou modificar a situação jurídica de modo que não implique o resultado pretendido pelo autor.

Mesmo que esse modelo seja capaz de resolver o problema da distribuição do ônus da prova na grande maioria dos casos, para alguns doutrinadores ele não serve como uma regra geral, diante, sobretudo, das dificuldades com a conceituação de natureza dos fatos e da fixação da posição processual das partes como um dos elementos de distinção. Examinaremos mais a fundo os problemas desse critério adiante, em tópico específico, ${ }^{193}$ após apresentação dos demais critérios de distribuição do ônus probatório.

\subsubsection{Onus distribuído pela regra das normas}

Diante das dificuldades de definição, em determinadas circunstâncias, da natureza dos fatos, bem como da normalidade ou anormalidade dos fatos ou ainda da essencialidade ou inovação, RoSENBERG propôs um modelo de distribuição do ônus da prova que não se vincula à posição das partes ou ao fato objeto da prova isoladamente considerado, mas sim à posição que o fato ocupa em relação à norma jurídica que se pretende seja aplicada, ou seja, o fato como pressuposto da aplicação de determinado preceito legal. ${ }^{194}$

Como exposto anteriormente, ROSENBERG sustenta que a distribuição do ônus da prova tem fundamento nos princípios da conveniência e da justiça, mas, para se evitar

\footnotetext{
193 Vide item "3.5”, a seguir.

194 Como afirma o aludido autor, “[...] el proceso concreto no ejerce influencia sobre la distribución de la carga de la afirmación y de la prueba. Esto mismo se manifiesta, además, en el hecho de que el papel de parte no tiene importancia para la distribución de la carga de la prueba” (La carga..., cit., p. 205).
} 
uma concepção individualista de justiça do juiz e garantir a segurança do sistema, a regra deve ser necessariamente estabelecida em lei. ${ }^{195}$

Ainda de acordo com RosenBERG, "cada parte deve afirmar e provar os pressupostos (de fato) da norma que lhe é favorável (= da norma cujo efeito jurídico redunda em seu proveito)", ${ }^{196}$ deslocando a relevância dos fatos para a própria norma, da qual os fatos são pressupostos de sua aplicação.

Toda pretensão deduzida em juízo está calcada em uma norma que lhe dá sustento. Essa norma, regulada pelo direito material, estabelece um preceito dos efeitos jurídicos decorrentes de determinados fatos. A ocorrência de tais fatos é o pressuposto para a produção dos efeitos jurídicos pretendidos. A demanda existe porque de alguma forma esses efeitos jurídicos não foram obtidos naturalmente.

O autor, ao formular o pedido, irá alegar os fatos que constituem o pressuposto da norma cujos efeitos ele quer sejam suplantados pela decisão judicial. Assim, incumbe ao autor, uma vez que esses fatos se tornarem controvertidos ou sobre eles não recair nenhuma das hipóteses de isenção da prova, o ônus de prová-los.

Ao réu, por seu termo, incumbiria o ônus de provar os fatos que constituem o pressuposto da norma jurídica por ele invocada em sua defesa para rechaçar a pretensão do autor.

Com essa abstração, busca-se estabelecer uma regra geral para a distribuição do ônus da prova, fundamentada nos pressupostos fáticos da norma que dá sustento à pretensão de cada uma das partes, o que equivale a dizer, em última análise, que a distribuição dos ônus probatórios deve ser realizada com base no interesse das partes no resultado buscado por cada uma delas no processo.

\footnotetext{
195 La carga..., cit., p. 114-116. Para o autor alemão, "la justicia se manifiesta en cada cabeza de modo distinto. La sentencia así lograda parecería arbitraria a las partes, y tal vez no estuvieran tan equivocadas al respecto. Sólo la justicia acrisolada a través de los siglos y configurada por el legislador, sólo la propia ley puede ser pauta y guía para el juez" (Op. cit., p. 116). 


\subsubsection{Onus distribuído pela regra dos efeitos jurídicos perseguidos}

Conforme a regra dos efeitos jurídicos perseguidos, a distribuição do ônus da prova não deve se pautar nos pressupostos da norma jurídica invocada, mas nos efeitos jurídicos pretendidos da norma jurídica invocada, que está definida no direito material, de modo que a atribuição dos respectivos ônus não ocorre de forma abstrata, mas de acordo com o caso concreto, distribuindo o ônus da prova a quem alegar o fato que resulta no efeito jurídico pretendido.

Assim como RosEnBERG, MichelLi também enfatiza a importância da norma de direito material para a definição do ônus da prova, repartindo-o a partir do efeito jurídico pretendido, mas, ao contrário do jurista alemão, não elimina por completo o aspecto processual, consistente na posição da parte no processo. Segundo sustenta,

[...] a repartição do ônus da prova é estabelecida precipuamente pela posição ocupada pela parte em relação ao efeito jurídico pedido: tal relação é determinada pelo direito material, enquanto este disciplina a hipótese legal, e pelo direito processual, enquanto se tenha presente o perfil unilateral adotado por cada uma das partes no processo, isto é, a situação processual posta em prática pela parte que formula uma própria demanda em juízo. ${ }^{197}$

Essa técnica, embora tente se distanciar da posição de ROSENBERG, em substância é equivalente àquela, na medida em que ambas examinam o mesmo fenômeno e chegam à mesma conclusão, mas a partir de pontos de vista diferentes.

Enquanto ROSENBERG examina o "início" (os pressupostos da norma), MiCHELLI analisa o "fim" (os efeitos pretendidos da norma), mas o resultado é o mesmo: cada parte tem o ônus de provar os fatos que constituem os pressupostos da(s) norma(s) que fundamenta(m) suas alegações e que, consequentemente, lhes trará os efeitos pretendidos.

A equivalência ocorre porque o elemento essencial da distribuição do ônus da prova para ambos é o mesmo: a norma de direito material que sustenta a pretensão de cada

197 “[...] la distribución de la carga de la prueba parece establecida principalmente por la posición, ocupada por la parte misma, respecto del efecto jurídico pedido: tal relación está determinada por el derecho sustancial, en cuanto este ultimo disciplina la hipótesis legal, por el derecho procesal, en cuanto se tenga presente el perfil unilateral, adoptado por cada una delas partes en el proceso, esto es, la situación procesal puesta en práctica por la parte, la cual formula una propia demanda en juicio" ( $\mathrm{La}$ carga..., cit., p. 386). 
uma das partes, sem que lhe predisponha, abstratamente, os qualitativos de constitutiva, extintiva, modificativa ou impeditiva, mas a posição concreta das partes diante das normas invocadas e os efeitos processuais perseguidos. ${ }^{198}$

Piero Calamandrei, ${ }^{199}$ Enrico Redenti ${ }^{200}$ e Giovanni Pavanini ${ }^{201}$ parecem se alinhar a essa corrente, haja vista que também levam em consideração na distribuição do ônus da prova a posição substancial das partes no processo e os efeitos jurídicos substanciais que perseguem pelo processo, à luz das normas invocadas como fundamento das suas pretensões.

No direito pátrio, ALFREDo BUZAID é o principal defensor desse critério de distribuição dos ônus probatórios, asseverando que

[...] a distribuição do ônus da prova parece estabelecida principalmente pela
posição, ocupada pela própria parte, em relação ao efeito jurídico pedido; tal
relação está determinada pelo direito material, enquanto disciplina a hipótese
legal; e pelo direito processual, enquanto tem presente o perfil unilateral adotado
por uma das partes no processo. Esta colocação do problema permite chegar a
resultados satisfatórios, seja por que deste modo se distingue o que alude à
valoração das provas, seja porque se dá o justo valor ao conteúdo da demanda
judicial, isto é, à afirmação de uma relação ou estado jurídico, formulado pelas
partes. $^{202}$

Portanto, pela regra dos efeitos jurídicos perseguidos, a distribuição do ônus da prova se dá conforme a posição das partes em relação aos efeitos concretos objetivados por cada uma, opondo-se, de certa forma, às técnicas anteriormente examinadas, que consideram a posição das partes em relação aos fatos, seus pressupostos em efeitos sempre em caráter abstrato.

198 Ora, realmente não nos parece haver distinção substancial entre os modelos de MiCHELI e ROSENBERG, sobretudo porque ambos se socorrem das normas de direito substancial para a definição da distribuição do ônus probatório, sem, contudo, considerar estas suficientes para a definição dos respectivos ônus das partes, sendo preciso examinar o efeito jurídico que cada parte procura extrair de determinada norma, bem como ambos reconhecem que não é possível uma predeterminação de normas constitutivas, extintivas ou impeditivas, cabendo o exame do caso concreto definir o efeito que determinada norma assumirá.

199 CALAMANDREI sustenta como "requisito" da ação a demonstração da relação entre o fato invocado e norma que sustenta a pretensão, de forma que o conteúdo da demanda é definido conforme o efeito jurídico pretendido da aludida norma jurídica a ser aplicada no caso concreto (Instituciones..., cit., v. 1, p. 182-183).

Para REDENTI, para a distribuição do ônus da prova deve-se considerar quem está legitimado pela norma de direito substancial para pedir o respectivo efeito jurídico em juízo, considerando-se, portanto a posição da parte em relação à pretensão (Profili pratici del diritto processuale civile. Milão: Giuffrè, 1938. p. 103-105). 


\subsubsection{0 Ônus distribuído pela regra das normas + regra dos efeitos jurídicos perseguidos}

Diante da apenas aparente contradição entre os modelos de ROSENBERG e MichelLI, ECHANDÍA propõe uma conciliação, em caráter conjuntivo ou mesmo redundante, entre os ensinamentos dos dois doutrinadores, sustentando que o ônus da prova deve ser atribuído com base nos pressupostos fáticos da norma e nos efeitos perseguidos. ${ }^{203}$

Para o professor colombiano, o ônus da prova incumbe à parte cuja alegação, em ação ou exceção, tenha o fato como "pressuposto necessário, de acordo com a norma jurídica aplicável” 204 ou, em outras palavras, "a cada parte corresponde o ônus de provar os fatos que servem de pressuposto à norma que consagra o efeito jurídico perseguido por ela, qualquer que seja a sua posição processual". ${ }^{205}$

A vantagem de tal descrição é aclarar que a distribuição do ônus da prova se relaciona com os interesses materiais pretendidos pelas partes no processo, cabendo-lhes o risco da derrota caso não resultem comprovados os fatos que fundamentam as suas respectivas pretensões, independentemente da sua posição processual, da natureza dos fatos, da sua normalidade ou anormalidade, ou da sua inovação.

\subsection{Modelo vigente no Código de Processo Civil de 1973}

O legislador pátrio, ao elaborar o Código de Processo Civil de 1973, influenciado pelos ensinamentos especialmente de CHIOVENDA ${ }^{206}$ e parcialmente de

\footnotetext{
203 "Los conceptos de Rosenberg y Michelli se complementan, y sólo se oponen en puntos secundarios [...]" (Teoría..., cit., t. 1, p. 488).

204 Teoría..., cit., t. 1, p. 490.

205 Teoría..., cit., t. 1, p. 490. Com essa definição, o referido processualista sustenta que "es cierto que al demandante le corresponde probar los hechos que alega como fundamento de su pretensión y, por lo tanto, los constitutivos de ésta, pero sólo en el sentido de que se trata de los previstos en la norma que invoca o que le es favorable como supuestos de su aplicación; también es cierto que al demandado le corresponde probar los hechos que alega como fundamento de su excepción y, en consecuencia, como impeditivos o extintivos de la pretensión del demandante, sólo en cuanto se trata de los que sirven de presupuesto a la norma cuya aplicación lo favorece, sea que la invoque o no" (Op. cit., p. 492). 
ROSENBERG, ${ }^{207}$ estabeleceu em seu artigo 333 a regra geral de distribuição do ônus da prova dispondo que:

Art. 333. O ônus da prova incumbe:

I - ao autor, quanto ao fato constitutivo do seu direito;

II - ao réu, quanto à existência de fato impeditivo, modificativo ou extintivo do direito do autor.

Da leitura do supracitado dispositivo legal extraímos que o modelo brasileiro adota dois critérios para definir a quem incumbe o ônus da prova: a posição das partes e a natureza dos fatos pressupostos das normas de direito material invocadas.

Quanto ao primeiro elemento da regra (distinção entre as partes no processo), a lei processual atribui ao autor, responsável pela remoção do Poder Judiciário da sua inércia, o ônus da prova do embasamento fático de suas alegações e que fundamentam o seu pedido (causa de pedir remota). O réu também é incumbido do ônus da prova em relação aos fatos novos que alega, desde que tenha o autor se desincumbido do seu ônus. ${ }^{208}$

Trata-se de regra primordial do direito romano, enraizada no senso jurídico de que quem alega tem que provar (semper onus probandi ei incumbit qui dicit, non qui negat), à qual já foi dada a correta interpretação no item “3.3.3” deste Capítulo, mas associando a essa máxima a natureza dos fatos alegados, para distinguir os fatos cujo ônus incumbe a parte daqueles fatos que são alegados em contraposição e que, em regra, não acarretam nenhum ônus da prova àquela parte que o alegou.

Como observa RosEnBERG, pela regra da Normentheorie, cada parte deve afirmar e provar os pressupostos de fato da norma que lhe é favorável, deslocando a relevância dos fatos à própria norma, da qual os fatos são pressupostos de sua aplicação. ${ }^{209}$

\footnotetext{
207 Vide item "3.3.8”.

208 Essa constatação, embora no plano teórico-doutrinário seja de fácil compreensão, sendo inquestionável no modelo vigente que os ônus das partes se sucedem e são condicionados (o réu somente se torna onerado se o autor cumprir o seu ônus), na dinâmica da instrução probatória não existe espaço para o réu "aguardar" o autor tentar produzir a prova de suas alegações e se desincumbir do seu ônus para, a seguir, o réu iniciar a produção das provas das suas alegações. Na prática, ambas as partes produzem as provas que lhes incumbem concomitantemente, não se questionando nesse momento a ordem de distribuição do ônus da prova, mas focando apenas quais provas cada parte deve produzir, daí por que a função subjetiva do ônus da prova ser essencial na construção e estruturação do arcabouço probatório, exigindo-se de ambas as partes esforços para provarem as suas respectivas alegações que embasam suas pretensões.

209 “A parte cuja petição processual não pode ter êxito sem que se aplique um determinado preceito jurídico suporta o ônus da afirmação e da prova de que as características definidoras desse preceito estejam realizadas nos fatos" (La carga..., cit., p. 123).
} 
No mesmo sentido, DinAmARCO assevera que o autor tem o ônus de afirmar "[...] a ocorrência de fatos que, segundo as normas de direito substancial, conduzem ao resultado jurídico permitido (causa de pedir: art. 282, inc. III, CPC)", e de sustentar "o nexo lógico existente entre os fatos narrados e o direito que afirma ter". ${ }^{210}$ Por seu turno, o réu tem o ônus “(d)a afirmação negativa dos fatos afirmados pelo autor (negação) ou a afirmação de fatos novos, em tese capazes de evitar que este obtenha a tutela jurisdicional pedida na demanda inicial". 211

E prossegue o referido processualista, destacando que:

[...] ao ônus de alegar segue-se como corolário quase constante o de provar as afirmações contidas na narrativa dos fatos. Esse encargo é estreitamente ligado à controvérsia instaurada no processo entre afirmações antagônicas das partes uma afirmando a ocorrência do fato e outra negando-a ou afirmando outros fatos que excluem a ocorrência daquele. ${ }^{212}$

A regra em exame, contudo, não se esgota com a definição dos interesses do autor e do réu quanto aos fatos que afirmam. É necessário analisar o conteúdo dessa afirmação e a natureza ou eficácia pretendida com os fatos por cada um deles alegados ${ }^{213}$.

O autor, ao formular a petição inicial, faz a descrição de diversos fatos que logicamente interligados devem acarretar uma consequência jurídica, que é o objeto da tutela jurisdicional pretendida. Entre os fatos narrados pelo autor existem fatos principais e fatos acessórios (ou instrumentais). ${ }^{214}$ Estes podem ou não ter relevância jurídica, conforme o contexto, ao passo que aqueles são pressupostos para que a norma invocada

$210 \quad$ Instituições..., cit., v. 2, p. 251.

211 Instituições..., cit., v. 2, p. 251; grifos do autor.

$212 \quad$ Instituições..., cit., v. 2, p. 257.

213 Com efeito, como sustenta RUI MANUEL DE FREITAS RANGEL, a "classificação dos factos jurídicos em constitutivos, impeditivos e extintivos não tem uma significação absoluta e abstracta, mas antes, relativa e concreta porque depende, em cada caso concreto, da função que o facto desempenha na acção de acordo com a posição das partes e o efeito jurídico que cada uma pretende obter por via do processo" (O ónus..., cit., p. 154).

214 Como distingue HENRIQUE ARAÚJO, “factos principais são todos os que integram a causa de pedir, fundando o pedido; factos instrumentais são aqueles cuja função é apenas probatória; não substanciam ou preenchem as pretensões jurídico-materiais do autor, mas da sua prova pode inferir-se a prova dos factos principais". E complementa, asseverando que "na petição inicial o autor deve, portanto, expor os factos principais e instrumentais necessários à procedência do pedido e, acessoriamente, mencionar as razões de direito, isto é, a interpretação e aplicação das regras jurídicas aos factos narrados. Este é o corolário do acolhimento pelo nosso direito processual civil da teoria da substanciação, que implica para o autor a necessidade de articular os factos de onde deriva a sua pretensão, formando-se o objecto do processo e, por arrastamento, o caso julgado, apenas relativamente aos factos integradores da causa de pedir invocada" [A matéria de facto no processo civil (da petição ao julgamento)]. Disponível em: <http://www.trp.pt/ficheiros/ estudos/henriquearaujo_materiafactoprocessocivil.pdf $>$. Acesso em: 15 nov. 2014. 
pelo autor como violada ou ameaçada seja reconhecida, e, assim, o autor possa alcançar o direito pretendido. ${ }^{215}$

De acordo com a regra insculpida no Código de Processo Civil, cabe ao autor a prova das alegações dos fatos principais e acessórios (eventualmente) controvertidos que "constituem" o direito pretendido, ou seja, incumbe ao autor provar as alegações de fato que embasam a sua pretensão, ou, utilizando a linguagem de ROSENBERG, os pressupostos fáticos da norma invocada.

Da mesma forma, o réu, em sua defesa, tem o ônus da impugnação específica, assim compreendida no contexto geral da defesa apresentada, a teor do que prescreve o artigo 302 do Código de Processo Civil, sob o risco de serem reconhecidos a revelia e os efeitos dela decorrentes.

Assim, na Contestação o réu deverá formular alegações de fato e de direito, ${ }^{216}$ podendo aquelas estar fundadas em fatos principais e acessórios, que tenham por objetivo: (i) refutar o(s) fato(s) principais alegado(s) pelo autor ${ }^{217}$, tornando-o(s) controvertido(s),

215 Assim, as alegações de fato e de direito devem estar para o pedido na mesma relação lógica em que as premissas de um silogismo estão para a conclusão. Se assim não ocorrer, e "da narração dos fatos não decorrer logicamente a conclusão", a petição inicial poderá ser considerada inepta, conforme determina o inciso II do parágrafo único do artigo 295 do Código de Processo Civil.

216 Em relação às alegações de direito, as opções do réu são: (i) negar os efeitos jurídicos pretendidos pelo autor a partir dos fatos alegados ("erro de qualificação"); (ii) dar outra interpretação jurídica aos fatos e/ou às normas invocadas pelo autor ("erro de interpretação"); e (iii) negar a existência dos efeitos jurídicos pretendidos no ordenamento ("erro de aplicação").

217 Em Portugal, também é expresso o ônus de impugnação do réu (artigo 574 do Código de Processo Civil de 2013), e segundo ANTONiO MontalaVÃo MACHAdo e PAUlO PIMENTA, é possível dividir essa impugnação ou "oposição de facto" em três espécies, quais sejam: impugnação direta ou absoluta (quando o réu contradiz os fatos alegados pelo autor), impugnação indireta, parcial ou "negação motivada" (quando o réu afirma que as coisas se passaram de modo parcialmente diverso e com outra significação jurídica) e o desconhecimento da veracidade do fato, desde que não "se trate de facto pessoal ou de que o réu deva ter conhecimento", conforme artigo 574.3 do Código de Processo Civil de 2013 (O novo processo civil. 4. ed. Coimbra: Almedina, 2002. p. 144-146). Exemplo típico de "negação motivada" é a alegação pelo réu, em ação de cobrança de quantia, que o valor lhe foi entregue pelo autor a título de doação, e não mútuo, como alega o autor. De qualquer forma, de acordo com ANTÓNIO JOSÉ FIALHO, "a defesa por impugnação implica sempre uma negação dos factos, ou dos seus efeitos jurídicos, através de negação simples e directa ou de negação motivada, que se traduz na alegação de outros factos distintos e opostos àqueles, dando-se uma nova versão da realidade" (A petição inicial. Disponível em: 〈http://www.fd.unl.pt/docentes_docs/ma/mfg_ma_8888.pdf〉. Acesso em: 15 nov. 2014. A "negação motivada" difere da alegação de fato modificativo, extintivo ou impeditivo porque naquela há negação do fato constitutivo do autor (ou ao menos de parte dos elementos que o compõem - doação em vez de mútuo) e nesta o fato é reconhecido como verdadeiro, mas são alegados outros fatos, com eficácia extintiva, modificativa ou impeditiva (v.g., pagamento, incapacidade etc.). Entretanto, como ressalta FIALHO, "a distinção entre negação motivada e a excepção peremptória é susceptível, na prática, de dúvidas, devendo-se, nesse caso, qualificá-la como 
sem assumir qualquer ônus probatório, pois a mera oposição à alegação de fato do autor tem o condão de tornar o ponto de fato em questão, a exigir sua comprovação pelo autor, a teor do já citado inciso I do artigo 333 do Código de Processo Civil; ${ }^{218}$ ou (ii) trazer ao conhecimento do juiz outros fatos capazes de elidir os efeitos do(s) fato(s) alegado(s) pelo autor, extinguindo, modificando ou impedindo os efeitos pretendidos pelo autor, quando então caberá ao réu o ônus da prova, conforme determina o inciso II do artigo 333 do Código de Processo Civil.

ARAÚJo CINTRA sintetiza esses efeitos atribuídos aos fatos jurídicos considerando

[...] constitutivo o fato que transforma uma situação antecedente genérica de liberdade em uma situação jurídica especificamente relevante de direito e obrigação; o fato é modificativo quando conduz de uma a outra situação especificamente relevante; e será extintivo o fato quando substitui uma situação especificamente relevante por uma situação de liberdade genérica. ${ }^{219}$

impugnação, pela maior garantia dada à verdade material em face dos efeitos resultantes da falta de resposta” (Op. cit., loc. cit.).

218 Para fins de distribuição do ônus da prova, independentemente da espécie de impugnação, o ônus será sempre do autor, pois, como afirma DINAMARCO, “em qualquer dessas hipóteses o réu está a negar o fato constitutivo alegado pelo autor e daí o ônus probatório lançado sobre este" (Instituições..., cit., v. 3, p. 464). No mesmo sentido é o entendimento de NElson DE MiRANDA MEdeIRos (O fato impeditivo e o ônus de prová-lo: ônus de prova de negativa. Revista do Tribunal Regional do Trabalho da 2. ${ }^{a}$ Região, São Paulo: LTr, n. 4, p. 19-33, 1979) e de GIUSEPPE CHIOvENDA, que adverte que, "mesmo em caso de negação indireta, isto é, de afirmação de um fato incompatível com o alegado pelo autor (negatio per positionem), não tem o réu, para o momento, de provar o fato que ele alega; portanto, se bem afirme um fato autônomo, o faz para negar o fato constitutivo de direito do autor, e não apenas para opor-se a seus efeitos jurídicos" (Instituições..., cit., v. 2, p. 380; grifos do autor). Interessante, ainda, é o posicionamento de MiCHELLI, que sustenta, em um primeiro momento, que diante de a alegação do réu se fundar em uma norma completamente diversa daquela que embasa a alegação do autor, com fundamento na "teoria das normas" de ROSENBERG, seria mesmo possível falar em um ônus da prova do réu em relação à "negação motivada", ou mesmo em ônus de ambas as partes, pois "desde un punto de vista abstracto, se puede observar que tanto vale una afirmación como otra [...]" (La carga..., cit., p. 356-357). Contudo, conforme o autor italiano, "la negación del demandado, ya sea simple o motivada, ha conservado, pues, en el proceso moderno, el valor que tenia en el proceso común: esto es, de hacer que necesite prueba la afirmación del adversario" (La carga..., cit., p. 358), concluindo que "[...] si el demandado se pone a la pretensión del actor, afirmando que el negocio es diverso de como lo presenta dicho actor, él niega, poniendo de este modo sobre este último la carga de la prueba de su aserto" (La carga ..., cit., p. 371, grifos do autor). No âmbito penal, o álibi é um exemplo típico de "negação motivada", pois, como sustenta GUSTAVO BADARó, "quem invoca um álibi, na verdade, está negando o fato constitutivo do direito de punir. Trata-se de negativa motivada ou per positionem. De qualquer forma, não se trata de alegação de fato diverso (modificativo, extintivo ou impeditivo) do fato constitutivo do direito do autor, que impeça sua eficácia jurídica" (O álibi do acusado e o in dubio pro reo no acórdão da Ação Penal 470/MG. Revista dos Tribunais, São Paulo: RT, v. 102, n. 933, p. 262, jul. 2013). Entretanto, em nosso sentir, sempre que a "negação motivada", de alguma forma, tiver como efeito extinguir, modificar ou impedir a pretensão do autor, caberá ao réu o ônus da prova, pois deixará de ser mera impugnação de fato e se tornará verdadeira "excepção peremptória". 
Portanto, conforme o modelo processual atualmente vigente, o ônus da prova é distribuído de forma geral e abstrata, calcado em um modelo de igualdade formal, que trata as partes sem discriminação, em que cada qual tem o ônus de provar os fatos que sustentam as suas respectivas pretensões, tomando-se como premissa tanto a posição das partes no processo quanto a natureza dos fatos a serem provados, e orientando-se pelo princípio da normalidade, o que, em verdade, é suficiente e adequado para solucionar a grande maioria das controvérsias sobre distribuição de ônus probatórios, mas não se encontra ileso a críticas, como trataremos no item seguinte.

\subsection{Insuficiência do modelo vigente no Código de Processo Civil de 1973}

O modelo adotado pelo Código de Processo Civil, calcado na posição das partes e na natureza dos fatos, aponta duas ordens de problemas, a justificar a sua insuficiência para dar uma solução justa à totalidade de conflitos submetidos ao Poder Judiciário, quais sejam: (i) a confusão em torno da definição de fato constitutivo, extintivo, modificativo e impeditivo do ponto de vista processual e material; e (ii) a não adoção da capacidade probatória como critério de atribuição do ônus probatório, sobretudo nas situações em que existe desigualdade na capacidade das partes de produzir provas.

O primeiro dos problemas, em nosso sentir, é um falso problema, pois resulta, única e exclusivamente, de uma má interpretação dos adjetivos "constitutivo", "extintivo", "modificativo" e "impeditivo" empregados no texto legal, confundindo a eficácia processual pretendida a partir da demonstração do fato com o resultado ou efeito sobre a relação de direito material a ser obtido desse fato (desde que provado).

Diz-se constitutivo, para efeitos de distribuição do ônus da prova, o fato que tem a pretensão de confirmar (constituir) o pressuposto fático da norma invocada pelo autor como fundamento do seu pedido. Esse fato "constitui" a base fática da pretensão do autor, que não se confunde com o resultado pretendido pelo autor, que atua diretamente sobre o direito material, podendo ser a constituição, extinção, modificação ou impedimento de um direito. 
O mesmo se aplica em relação ao réu, que tem o ônus de provar as alegações de fato que podem gerar efeitos impeditivos, extintivos ou modificativos sobre a pretensão do autor. Cabe ao réu demonstrar fatos que tenham a eficácia de impedir, modificar ou extinguir a pretensão do autor, e que, por seu turno, também são "constitutivos" em relação ao pressuposto fático da norma evocada pelo réu para sustentar suas alegações.

A confusão pode surgir porque um mesmo fato pode gerar efeitos processuais diversos, ora constitutivo, ora extintivo, modificativo ou impeditivo. De fato, em determinadas situações, por exemplo, a incapacidade da parte, se afirmada pelo réu para negar os efeitos do negócio jurídico, é fato impeditivo da pretensão do autor que quer se valer de um negócio celebrado com o incapaz. Por outro lado, a incapacidade pode ser alegada pelo autor como fato constitutivo do seu direito em ação anulatória de negócio jurídico celebrado com incapaz.

Do ponto de vista processual, portanto, as alegações de fato do autor serão sempre constitutivas do direito pretendido, mas substancialmente esse mesmo fato pode ser impeditivo, modificativo ou impeditivo para a configuração de outro direito.

Em face de tal imprecisão na classificação dos fatos em constitutivos, extintivos, modificativos ou impeditivos, os modelos "modernos" de distribuição do ônus da prova, em especial aqueles desenvolvidos por RosenberG, ${ }^{220}$ MiCHELLI $^{221} \mathrm{e}$ ECHANDÍA, ${ }^{222}$ e seguidos por muitos outros, propugnam pelo abandono da natureza dos fatos como elemento de atribuição dos respectivos ônus probatórios. ${ }^{223}$

\footnotetext{
220 Vide item "3.3.8".

221 Vide item "3.3.9".

222 Vide item "3.3.10".
}

223 A posição das partes também parece se tornar irrelevante (embora não totalmente abandonada por MICHELLI (vide item “3.3.9”), pois ambas as partes têm que provar os pressupostos e/ou os efeitos das normas de direito material que invocam como fundamento das suas alegações, independentemente da posição processual que ocupam. Ou seja, o elemento central é o interesse no resultado do processo, conforme já sustentava CARNELUTTI (vide item “3.3.7”). ROSENBERG (La carga..., cit., p. 152-153) e MiCHELLi (La carga..., cit., p. 303-305) também criticam o modelo calcado exclusivamente no princípio da normalidade por confundir o ônus da prova com a valoração da prova. Segundo os referidos autores, as regras jurídicas que definem "o que normalmente ocorre" e "o curso natural das coisas" funcionam como elemento de apreciação da prova, de que se vale o juiz para averiguar os elementos de prova para formar o seu convencimento, dado que essa valoração deve ocorrer em momento antecedente ao julgamento, enquanto somente se cogitará de se utilizar a regra de distribuição do ônus da prova no ato de julgar quando inexistirem provas ou elas forem inconclusivas. 
Alguns estatutos processuais estrangeiros já abandonaram a distribuição do ônus da prova calcada na natureza dos fatos para enfatizar o critério do interesse a quem a prova do fato aproveita.

Nesse sentido, o artigo 377 do Código Procesal Civil y Comercial de la Nación da Argentina de 1981 prevê que:

Artigo 377. Incumbirá la carga de la prueba a la parte que afirme la existencia de un hecho controvertido o de un precepto jurídico que el juez o el tribunal no tenga el deber de conocer.

Cada una de las partes deberá probar el presupuesto de hecho de la norma o normas que invocare como fundamento de su pretensión, defensa o excepción. ${ }^{224}$

Da mesma forma, em Portugal, o Código de Processo Civil de 2013, repetindo a redação do Código de 1961, traz a seguinte previsão:

Artigo $414 .^{\circ}$ Princípio a observar em casos de dúvida.

A dúvida sobre a realidade de um facto e sobre a repartição do ónus da prova resolve-se contra a parte a quem o facto aproveita. ${ }^{225}$

$\mathrm{Na}$ Espanha, a reforma de 2000 na Ley de Enjuiciamiento Civil, embora tenha trazido importantes inovações, como a possibilidade de flexibilização do ônus da prova conforme a "disponibilidade" e "facilidade" probatória das partes, não abandonou completamente o critério da natureza dos fatos como critério de distribuição dos ônus probatórios, dispondo que:

Artículo 217. Carga de la prueba

1. Cuando, al tiempo de dictar sentencia o resolución semejante, el tribunal considerase dudosos unos hechos relevantes para la decisión, desestimará las pretensiones del actor o del reconviniente, o las del demandado o reconvenido, según corresponda a unos u otros la carga de probar los hechos que permanezcan inciertos y fundamenten las pretensiones.

224 Ao comentar o aludido dispositivo legal, ROLAND ARAZI critica a redação, em face de uma possível contradição entre os dois parágrafos, pois enquanto no primeiro se consagra a regra de que quem alega um fato tem o ônus de prová-lo, no segundo tentou-se incorporar a técnica de ROSENBERG, embora de forma imperfeita (a prova não seria do pressuposto da norma invocada pela parte, mas da norma a ser aplicada, ainda que não invocada pela parte), sugerindo que seria melhor a supressão do primeiro parágrafo e a correção do segundo. E conclui, "en rigor la ley mira más el aspecto subjetivo de la carga, es decir aquél destinado a dar una regla para las partes, que al aspecto objetivo, que determina una regla de juicio dirigida al juez y que es lo que debe enunciar la norma legal, con carácter general aplicable a todos los procesos" (La prueba en el proceso civil. 2. ed. Buenos Aires: La Rocca, 1998. p. 111-112).

225 Para RUi MANUEL DE FREITAS RANGEL, o regime legal português sobre o ônus da prova, composto pela referida regra do Código de Processo Civil e o artigo 342 do Código Civil, adotou a regra sustentada por BETTI e ROSENBERG, pois "os factos integradores da previsão da norma, que aproveitam à pretensão ou à excepção invocadas pelas partes, terão que ser alegados e provados por cada uma delas", ou seja, "cada uma das partes tem que provar os factos que constituem os pressupostos da norma que lhes é favorável” ( $O$ ónus..., cit., p. 146 e 150). 
2. Corresponde al actor y al demandado reconviniente la carga de probar la certeza de los hechos de los que ordinariamente se desprenda, según las normas jurídicas a ellos aplicables, el efecto jurídico correspondiente a las pretensiones de la demanda y de la reconvención.

3. Incumbe al demandado y al actor reconvenido la carga de probar los hechos que, conforme a las normas que les sean aplicables, impidan, extingan o enerven la eficacia jurídica de los hechos a que se refiere el apartado anterior.

4. En los procesos sobre competencia desleal y sobre publicidad ilícita corresponderá al demandado la carga de la prueba de la exactitud y veracidad de las indicaciones y manifestaciones realizadas y de los datos materiales que la publicidad exprese, respectivamente.

6. Las normas contenidas en los apartados precedentes se aplicarán siempre que una disposición legal expresa no distribuya con criterios especiales la carga de probar los hechos relevantes.

7. Para la aplicación de lo dispuesto en los apartados anteriores de este artículo el tribunal deberá tener presente la disponibilidad y facilidad probatoria que corresponde a cada una de las partes del litigio. ${ }^{226}$

A par do problema de conceituação da natureza dos fatos e do seu abandono ou não como critério de distribuição do ônus da prova, o real entrave existente no modelo vigente no Brasil, e que nos permite afirmar ser um critério insuficiente, está na adoção, como premissa geral, da existência de uma situação de igualdade permanente entre os litigantes, tanto na fase pré-processual como em todo o desenvolvimento do procedimento em contraditório, o que, como é cediço, nem sempre ocorre.

Em um processo em que as partes litigam em uma situação de igualdade (formal e material), o elemento de distinção do ônus da prova de cada parte consiste, em essência, nos interesses perseguidos por essas partes no processo, devendo cada uma delas provar as alegações de fato que sustentam as suas respectivas pretensões.

No nosso modelo atual não é diferente, como acabamos de expor no item precedente, mas ele somente funciona para as situações ideais, em que há igualdade de participação, oportunidade e influência no resultado do processo, desde que bem

226 Conforme relata SILVIA GARCÍA-CUERVA GARCÍA, a lei espanhola adota o critério da natureza dos fatos formulado por CHIOVENDA, uma vez que "acorde con el artículo 217.2 y 3 LEC corresponde al actor o demandado reconviniente la carga de la prueba de los hechos constitutivos y al demandado o al actor reconvenido la de los hechos impeditivos, extintivos y excluyentes (o enervantes). Esta nueva distribución de la carga de la prueba supuso un avance para con la anterior fundada en al aforismo incumbit probatio qui dicit non qui negat que ya era criticada por la jurisprudencia de nuestro más alto tribunal", mas diante da dificuldade em conceituar abstratamente os fatos em constitutivos, impeditiso, extintivos ou modificativos, "las reglas generales de distribución de la carga de la prueba deben ser completadas con los principios de normalidad y de facilidad probatoria" (Las reglas generales del onus probandi. In: PICÓ I JUNOY, Joan; ABEL LLUCH, Xavier (Dir.). Objeto y carga de la prueba civil. Barcelona: Bosch Editor, 2007. p. 63). 
compreendido o sentido de fato constitutivo, extintivo, modificativo e impeditivo a que se referem os incisos I e II do artigo 333 do Código de Processo Civil.

Ocorre que, em algumas oportunidades, esse pressuposto da igualdade entre as partes litigantes não se confirma, sobretudo em relação à capacidade de produzir as provas que lhes incumbem, a exigir uma reformulação ou "flexibilização" da técnica de distribuição do ônus da prova atualmente existente, não no sentido de substituí-la por um modelo completamente distinto, haja vista ser forçoso reconhecer a funcionalidade da regra legal vigente para os casos em que a igualdade se verifica, mas para se estabelecer uma "válvula de escape", de uso excepcional, quando essa igualdade é quebrada, de forma que o juiz possa atingir a justiça, tratando igualmente os iguais e desigualmente os desiguais, mas sempre na medida de sua desigualdade, conforme clássica lição de RUI BARBOSA, na Oração aos moços. ${ }^{227}$

Ainda que fundamentado em outras premissas e apontando solução distinta, é indispensável expor o pensamento de DinAMARCo quanto aos riscos de uma postura inerte do juiz perante os pesos atribuídos ao ônus da prova à luz do exame do caso concreto. Como adverte o processualista paulista, seria "antissocial" e "insensível” a exacerbação da imobilidade do ônus da prova em situações em que se mostrasse o alto grau de dificuldade para sua desincumbência (probatio diabolica), afrontando, inclusive, a moderna visão teleológica e instrumentalista do sistema processual, cravando que é preciso "combater os exageros no seu dimensionamento". 228

A necessidade de se combater o desarrazoado dimensionamento do ônus da prova se mostra ainda mais evidente nas situações em que esse peso de provar as respectivas alegações de fato rompe o equilíbrio desejado e necessário entre os litigantes, exigindo do juiz uma postura ativa para restabelecer esse equilíbrio, valendo-se, como

227 “A regra da igualdade não consiste senão em quinhoar desigualmente aos desiguais, na medida em que se desigualam. Nesta desigualdade social, proporcionada à desigualdade natural, é que se acha a verdadeira lei da igualdade. O mais são desvarios da inveja, do orgulho, ou da loucura. Tratar com desigualdade a iguais, ou a desiguais com igualdade, seria desigualdade flagrante, e não igualdade real" (Disponível em: <http://www.casaruibarbosa.gov.br/dados/doc/artigos/rui_barbosa/fcrb_ RuiBarbosa_Oracao_aos_mocos.pdf >. Acesso em: 25 nov. 2014).

228 "Não há razão para correr riscos maiores de errar contra o autor, só para não correr riscos de errar contra o réu. Isso não corresponde a propor o afastamento do próprio onus probandi da técnica processual, mas a combater os exageros no seu dimensionamento" (A instrumentalidade..., cit., p. 300). 
defendemos neste trabalho, do emprego das técnicas de flexibilização do ônus da prova, como as presunções relativas e a distribuição dinâmica do ônus da prova, deslocando parte desse encargo de uma das partes para a outra.

\section{Como sustenta BARBOSA MOREIRA,}

[...] varias circunstancias concurren a menudo para desequilibrar las fuerzas de los litigantes; y, cuando ello acaece, la observancia misma de las reglas formales de igualdad se convierte en manantial de privilegio para el uno y de desmedro para el otro. [...] En la medida en que es susceptible de desviar el itinerario procesal de su meta auténtica, la desigualdad material entre las partes introduce en el aparato de la justicia una deformación contra la cual el ordenamiento tiene que reaccionar con energía [...], un verdadero "deber de protección" de la parte más débil - entendióndose como tal no necesariamente y siempre la que pertenezca a una clase económicamente o socialmente más humilde, sino la qué se halle in concreto en una situación de inferioridad en el proceso, no fundada en razones estrictamente jurídicas. La asunción de semejante rol por el juez está justificada, por vía de principio, toda vez que la interpretación de las reglas sobre igualdad sobreponga el aspecto material de ésta a su aspecto formal [...]. ${ }^{229}$

A grande falha, portanto, do critério da distribuição do ônus da prova com base na posição das partes e na natureza dos fatos atualmente vigente está em seu enfoque exclusivamente processual (partes e pressuposto fático das respectivas pretensões), calcado na premissa da igualdade formal, sem se preocupar com a condição das partes, sobretudo no que se refere às suas capacidades probatórias, e com o risco do desequilíbrio, que somente é verificável à luz do exame do caso concreto, e não a partir de normas preestabelecidas e abstratas.

Apesar das críticas, o projeto do novo Código de Processo Civil, na atual redação do artigo $370,{ }^{230}$ mantém no caput a mesma redação do atual artigo 333, com uma distribuição do ônus da prova baseada na posição das partes e na natureza dos fatos.

A inovação do texto projetado, por certo, está em seus parágrafos, que preveem a possibilidade de o juiz "dinamizar" a distribuição do ônus "diante de peculiaridades da causa, especialmente relacionadas à impossibilidade ou à excessiva dificuldade de cumprir o encargo [...] ou à maior facilidade de obtenção da prova do fato contrário", desde que o faça por decisão fundamentada e dando "à parte a oportunidade de se desincumbir do ônus que lhe foi atribuído".

\footnotetext{
$229 \quad$ La igualdad..., cit., p. $72-74$ e 76.

230 Disponível em: <http://www.senado.gov.br/atividade/materia/getPDF.asp?t=157884\&tp=1>. Acesso em: 10 dez. 2014
} 
Nos Capítulos seguintes procuraremos apresentar soluções para as situações em que as parte encontram-se em situação de desigualdade no processo.

O foco do nosso estudo será a técnica da distribuição dinâmica do ônus da prova, a qual surge como um mecanismo complementar à técnica geral e abstrata, especificamente quando a desigualdade entre as partes residir nas respectivas capacidades probatórias, cuja aplicação depende da observância de requisitos objetivos e o atendimento de certas condicionantes, para se evitarem os "sérios riscos de incerteza e de aleatoriedade" ${ }^{, 231}$ que poderiam existir com o estabelecimento de uma regra excepcional de distribuição dos ônus probatórios, a pretexto de se fazer "a justiça do caso concreto". ${ }^{232}$

Antes de analisarmos essa técnica, contudo, faremos uma exposição do mecanismo atualmente existente no Código de Defesa do Consumidor, que também permite uma flexibilização na regra rígida e abstrata do artigo 333 do Código de Processo Civil, e, como procuraremos expor, guarda muitas semelhanças com a técnica da distribuição dinâmica do ônus da prova stricto sensu.

\subsection{Critérios "dinâmicos" de distribuição do ônus da prova}

O primeiro critério "dinâmico" de distribuição do ônus da prova pode ser identificado na obra de JEREMY BENTHAM, o qual defende, à luz de um direito natural, que o ônus da prova deve incumbir àquela parte que se encontra em melhores condições de

231 COMOGLIO, Luigi Paolo. Le prove civili. 3. ed. Torino: UTET, 2010. p. 323.

232 TARUFFO, em mais de uma oportunidade, opõe-se veementemente à adoção de técnicas de modificação dos ônus probatórios, sobretudo quando ausentes critérios legais "prestáveis e coerentes de valoração", e quando definidas apenas no momento de proferir sentença, o que ofenderia o contraditório, entendendo ser algo perigoso, pois poderia atribuir ao juiz a definição do êxito na controvérsia (O ônus como figura processual..., cit., p. 426-431; e Uma simples verdade...., cit., p. 265-270). Concordamos com o professor italiano, pois realmente a falta de critérios objetivos para a modificação dos respectivos ônus probatórios ou a sua definição apenas no momento da sentença afrontam as garantias da segurança jurídica e do contraditório, dando poderes discricionários ao juiz para definir o resultado do processo. Contudo, o modelo que propomos procura minimizar esses riscos (excluí-los seria impossível) por meio do estabelecimento de requisitos e condicionantes objetivos para sua aplicabilidade (por exemplo, a vedação da prova diabólica inversa), até da necessidade de sempre oportunizar à parte que se tornou onerada se desincumbir de tal ônus, de modo que o contraditório se desenvolva regularmente e a prova possa ser produzida, para que a solução do conflito não precise se realizar por meio da regra de juízo (função objetiva do ônus da prova). 
produzi-la, vale dizer, que pode produzir a prova com menos inconvenientes, dilações, vexações ou custos. $^{233}$

A ideia originária desse critério consiste na preservação do status quo e a presunção de liberdade, enquadrada em um modelo jusnaturalista em que não deve haver normas predispostas sobre a distribuição do ônus da prova.

O juiz, ao examinar o caso concreto, determinará a parte onerada conforme apresente melhores condições para a obtenção da prova.

Esse pensamento jusnaturalista é indicado por alguns autores como a origem da técnica de distribuição dinâmica do ônus da prova, mas, como exporemos no item " 5.5 " do Capítulo 5, esses modelos não se confundem, uma vez que as premissas para o critério ora em exame e aquele a que dedicamos o presente trabalho são completamente distintas. Aqui, prevalece o ideal de um processo como um apêndice do direito material. Lá, predominam os ideais de justiça distributiva, busca da verdade, igualdade material e pacificação social.

Mais recentemente, no Código de Defesa do Consumidor, foi prevista uma regra de distribuição dinâmica do ônus da prova, decorrente da vulnerabilidade do consumidor diante do fornecedor. Dada sua relevância e total sintonia com o tema central deste trabalho, dedicaremos o Capítulo 4 para discorrer sobre o tema.

Por fim, temos a técnica da distribuição dinâmica do ônus da prova stricto sensu, desenvolvida a partir dos pensamentos de JoRGE W. PEYRANO na Argentina, sobre a qual nos debruçaremos nos Capítulos 5 e 6.

233 Tratado de las pruebas judiciales. Tradução Don J. G. de Castro. Madrid: Tomas Jordan, 1835. t. 2, p. 113. 


\section{CAPÍTULO 4 \\ DISTRIBUIÇÃO DO ÔNUS DA PROVA NOS PROCESSOS QUE ENVOLVEM RELAÇÕES CONSUMERISTAS}

A Lei n. ${ }^{\circ}$ 8.078, de 11 de setembro de 1990, consubstanciada na garantia fundamental de defesa do consumidor (artigo 5. ${ }^{\circ}$, inciso XXXII, e artigo 170, inciso V, ambos da Constituição Federal), e objetivando amparar a sua vulnerabilidade perante o fornecedor, estabeleceu regras materiais e processuais de proteção ao consumidor.

A vulnerabilidade do consumidor, aliás, é tratada como uma presunção absoluta nas relações de consumo, conforme definido no artigo $4 .^{\circ}$, inciso I, da referida Lei n. ${ }^{\circ} 8.078 / 1990$.

A partir dessa premissa de desigualdade entre consumidor e fornecedor, o Código de Defesa do Consumidor trouxe alguns mecanismos para reequilíbrio dessa equação, para uma correta aplicação da justiça e do princípio da igualdade material, no sentido de tratar desigualmente os desiguais, na medida da sua desigualdade, a que já nos referimos anteriormente.

No âmbito processual, a principal técnica de balanceamento de forças entre consumidor e fornecedor foi a criação de normas prevendo a possibilidade de "inversão",234 do ônus da prova, tanto ope legis ${ }^{235}$ como ope judicis.

234 No item "4.2" criticaremos a uso da expressão "inversão do ônus da prova" e sua impropriedade técnica, razão pela qual deixaremos de utilizar o substantivo "inversão", ainda que consagrado na doutrina e na jurisprudência, e passaremos a utilizar termos como "redistribuição" ou correlatos. Excepcionalmente, quando empregada a expressão "inversão" ou suas variações utilizaremos sempre entre aspas.

235 Para KAZUO WATANABE a hipótese de inversão judicial não se trata verdadeiramente de uma inversão do ônus da prova, pois o que ocorre "[...] é que o magistrado, com a ajuda das máximas de experiência e das regras da vida, considera produzida a prova que incumbe a uma das partes. Examinando as condições de fato com base em máximas de experiência, o magistrado parte do curso normal dos acontecimentos e, porque o fato é ordinariamente a consequência ou o pressuposto de um outro fato, em caso de existência deste, admite também aquele como existente, a menos que a outra parte demonstre o contrário. Assim, não se trata de uma autêntica hipótese de inversão do ônus da prova. Cuidou o legislador, apesar disso, de explicitar a regra e o fez com propósitos didáticos, para lembrar aos operadores do Direito, não muito propensos a semelhante critério de julgamento, que é ele inafastável em processos que tenham por conteúdo o direito do consumidor (Código brasileiro de Defesa do Consumidor comentado pelos autores do anteprojeto. 6. ed. Rio de Janeiro: Forense, 2000. p. 712-713). Concordamos com o mencionado processualista, e criticamos o emprego do termo 
Quanto à utilidade do estudo da técnica de distribuição do ônus da prova nos processos que envolvem relações consumeristas

Como procuraremos evidenciar ao longo da exposição, a técnica de redistribuição do ônus da prova estabelecida no Código de Defesa do Consumidor antecipou, para o direito brasileiro, a essência da técnica de distribuição dinâmica desenvolvida na Argentina, com algumas pequenas nuances quanto aos requisitos, mas enormes no tocante ao emprego da técnica, as quais serão expostas na sequência e que após a apresentação da técnica dinâmica serão confrontadas no item "5.8" do Capítulo 5.

Portanto, o estudo desse instituto, que já foi amplamente debatido e discutido na doutrina pátria, ${ }^{236}$ ajudará a fixar as bases conceituais da técnica dinâmica, que surge como uma "novidade", mas que, como veremos, tem as mesmas raízes ideológicas da técnica da redistribuição judicial estabelecida no inciso VIII do artigo $6 .^{\circ}$ da Lei n. ${ }^{\circ}$ $8.078 / 1990$.

"inversão" tanto nas hipóteses de "inversão" ope legis como ope judicis (como será detidamente examinado no item "4.2").

236 BORTOWSKI, Marco Aurelio Moreira. A carga probatória segundo a doutrina e o Código de Defesa do Consumidor. Revista de Direito do Consumidor. São Paulo: Revista dos Tribunais, n. 7, jul./set., 1993. WAMBIER, Teresa Arruda Alvim. Noções gerais sobre o processo no Código do Consumidor. Revista de direito do consumidor. São Paulo: RT, n. 10, abr.-jun. 1994, e Reflexões..., cit.. PACÍFICO, Luiz Eduardo Boaventura. Direitos básicos do consumidor: a facilitação da defesa dos consumidores e a inversão do onus da prova. Revista de Direito do Consumidor. São Paulo: Revista dos Tribunais, n. 10, abr./jun., 1994. BARBOSA MOREIRA, Carlos Roberto. Notas sobre a inversão do ônus da prova em benefício do consumidor. Revista de Direito do Consumidor, São Paulo: RT, $\mathrm{n}$. 22, abr.-jun. 1997. CARVALHO, José Carlos Maldonado de. A inversão do ônus da prova e a inversão do encargo decorrente sob a ótica do direito do consumidor. Revista de Direito do Consumidor, São Paulo: RT, v. 12, n. 46, abr.-jun. 2003. DELL'ISOLA, Carmela. O ônus da prova e sua inversão no processo civil. 2001. Dissertação (Mestrado em Direito) - Faculdade de Direito, Universidade de São Paulo, São Paulo. GIDI, Antonio. Aspectos da inversão do ônus da prova no Código de Defesa do Consumidor. Revista de Direito do Consumidor, São Paulo: RT, n. 13, jan.-mar. 1995. GRINOVER, Ada Pellegrini et al. Código..., cit. HOFFMAN, Paulo. Inversão do ônus da prova prevista no Código de Defesa do Consumidor - Critério de julgamento (sob a ótica do juiz) e critério de procedimento (para o fornecedor). In: CARVALHO, Fabiano; BARIONI, Rodrigo (Coord.). Aspectos processuais do Código de Defesa do Consumidor. São Paulo: RT, 2008. MATOS, Cecília. Ônus da prova no Código de Defesa do Consumidor. Dissertação (Mestrado em Direito) - Faculdade de Direito, Universidade de São Paulo, São Paulo, 1993, e O ônus da prova no Código de Defesa do Consumidor. Revista do de Direito do Consumidor, São Paulo: RT, n. 11, jul.-set. 1994. MORAES, Voltaire de Lima. Anotações sobre o ônus da prova no Código de Processo Civil e no Código de Defesa do Consumidor. Revista de Direito do Consumidor, São Paulo: RT, n. 31, jul.-set. 1999. NERY JUNIOR, Nelson. Aspectos do processo civil no Código de Defesa do Consumidor. Revista de Direito do Consumidor, São Paulo: RT, n. 1, mar. 1992. NOGUEIRA, Tânia Lis Tizzoni. A prova no direito do consumidor. Curitiba: Juruá, 2001. RIBEIRO, Débora de Oliveira. Inversão do ônus da prova no código de defesa do consumidor. 2005. Dissertação (Mestrado em Direito) - Faculdade de Direito, Universidade de São Paulo, São Paulo. SANTOS, Ernane Fidélis dos. O ônus da prova no Código de Defesa do Consumidor. Revista de Direito do Consumidor, São Paulo: RT, v. 12, n. 47, jul.-set. 2003. SANTOS, Sandra Aparecida Sá dos. A inversão do ônus da prova. 2. ed. São Paulo: RT, 2006. SICA, Heitor Vitor Mendonça. Questões velhas..., cit., entre tantos outros. 


\subsection{Crítica à expressão "inversão do ônus da prova" utilizada no Código de Defesa do Consumidor}

Não obstante a expressão "inversão do ônus da prova" estar consagrada no Código de Defesa do Consumidor, assim como na doutrina e até no senso comum de quem trata da matéria, tecnicamente ela não está correta.

O verbo inverter significa, de acordo com o Novo dicionário eletrônico Aurélio, "virar em sentido contrário ao natural", "colocar às avessas", "trocar a ordem em que estão colocados", "alterar" ou "mudar completamente", ${ }^{237}$ de sorte que a expressão "inversão do ônus da prova" somente teria sentido se consistisse na retirada do ônus de provar de uma das partes e transferi-lo (o mesmo ônus), por inteiro, à outra. Ou seja, a parte inicialmente onerada deixaria de estar onerada e a outra parte passaria a ter exatamente o mesmo ônus da prova que a parte primitiva teria, o que, por certo, é tecnicamente equivocado.

Ao se admitir essa incongruência, com a "inversão", a parte que se tornou onerada teria a incumbência de provar o fato constitutivo da pretensão de seu adversário, que, em regra, lhe é desfavorável, não havendo nenhum interesse da parte ora onerada de fazer tal prova, além de configurar flagrante ofensa ao direito das partes de não produzir prova contra si mesmo (nemo tenetur se detegere). ${ }^{238}$

Na chamada "inversão" do Código de Defesa do Consumidor, a parte que se torna onerada não terá exatamente o mesmo ônus de provar aquilo que a parte inicialmente onerada tinha o ônus de provar.

Não ocorre, portanto, a “inversão" do ônus da prova de uma parte à outra, mas um deslocamento de cargas probatórias, com o incremento de ônus de uma das partes e a redução de ônus da outra parte, com a alteração do thema probandum, da afirmação (positiva ou negativa) de um fato formulado por uma parte para a afirmação contrária

237 FERREIRA, Aurélio Buarque de Holanda. Novo dicionário eletrônico Aurélio. 3. ed. São Paulo: Positivo, 2004. CD-ROM.

238 Voltaremos a falar sobre o direito de não produzir prova contra si mesmo no item "5.1.3", oportunidade em que exporemos a inexistência de conflito entre o referido direito e a técnica da distribuição dinâmica do ônus da prova. 
(positiva ou negativa) da outra parte, daí por que nos parece mais correto falar em modificação ou redistribuição do ônus probatório em vez de "inversão".

Repita-se, a técnica denominada de "inversão" do ônus da prova, em verdade, não inverte o ônus da prova, que implicaria uma transferência do ônus de provar o fato $\mathrm{X}$ da parte A para a parte B, mas o que a aludida técnica faz é retirar o ônus de provar o fato $\mathrm{X}$ da parte A e estabelecer um novo ônus de provar o fato $\mathrm{Y}$ (contrário ao fato $\mathrm{X}$ ) para a parte B.

Se, pela regra geral e abstrata de distribuição do ônus da prova, a parte originalmente onerada deveria provar todos os elementos constitutivos (positivos ou negativos) da sua pretensão, com a "inversão", passa a ser ônus da parte contrária a prova de que algum ou alguns desses elementos configuradores da pretensão da parte contrária não se constituiu.

Eis mais uma crítica ao emprego do termo "inversão", que poderia levar a uma interpretação de que se transferiria à outra parte do ônus de provar todos os elementos que fundamentam a pretensão da parte contrária, o que é incorreto.

A “inversão" do ônus da prova somente ocorrerá em relação às alegações de fatos em que se verificar a presença dos requisitos autorizadores da redistribuição (a serem examinados em seguida), e não quanto a todos os fatos narrados pela parte que se beneficia da redistribuição.

Nesse sentido, ARTUR CARPES ressalta que o termo "inversão" "aspira a consagrar a transferência integral dos ônus probatórios de uma parte à outra, nada ressaltando quanto às circunstâncias de fato cujo encargo de prova deva ser efetivamente ser (sic) transferido". 239

Observa o referido autor, ainda, que as alegações que fundamentam as pretensões das partes são formadas por uma complexa rede de fatos e que nem todos preenchem os requisitos da "inversão", concluindo que o termo é inadequado por exprimir 
a mera transferência do sujeito onerado, sem se atentar para as peculiaridades do caso concreto, salvo se houver no ato (judicial) de "inversão" a exata extensão dos fatos cujo ônus da prova será "invertido", o que, contudo, em nosso sentir, deixa de ser "inversão" e passa a ser verdadeiro deslocamento de ônus probatórios.

HEITOR SICA também explica essa condição de individualização dos fatos que podem ser objeto de redistribuição, sempre condicionados à observância dos requisitos autorizadores, alterando especificamente o ônus da prova para os casos envolvendo relação de consumo, uma vez que

[...] para cada fato probando deve haver a análise da presença ou não da hipossuficiência. Ou seja, uma vez presente este requisito quanto a um particular fato controvertido, isso não significa que todo o ônus probatório será invertido em favor do consumidor. A inversão se restringe àquele ponto para o qual haja uma disparidade quanto ao controle da informação entre consumidor e fornecedor. $^{240}$

Portanto, o uso do termo "inversão" se mostra imperfeito para expressar o fenômeno que descreve, seja porque não é uma mera transferência subjetiva do ônus de provar o mesmo fato, o que exigiria da parte que se torna onerada a produção de prova contra si mesmo, o que é proibido pelo sistema, seja porque a "inversão" não acarreta a transferência integral do ônus de uma parte a outra, mas apenas pode ocorrer em relação aos fatos que preenchem os requisitos da redistribuição, permanecendo a parte originalmente onerada com o ônus de provar os demais fatos para obter o êxito em sua pretensão formulada em juízo.

\subsection{Hipóteses de redistribuição legal do ônus da prova}

A hipótese mais comumente lembrada de redistribuição legal do ônus da prova no Código de Defesa do Consumidor está prevista no artigo 38, que impõe ao fornecedor o ônus da prova da veracidade e correção da informação ou comunicação publicitária que patrocina.

Trata-se de uma imposição legal, ao fornecedor, de sempre ter que provar a retidão das informações publicitárias, ainda que impugnadas por um consumidor, o qual,

240 Questões velhas..., cit., p. 53. 
pela regra geral, teria o ônus de provar essa alegação de irregularidade. Ou seja, se um consumidor promove uma medida judicial fundada em suposto equívoco em um informe publicitário para pleitear uma indenização, pela regra geral caberia ao consumidor a prova dos pressupostos fáticos do seu pedido (causa de pedir remota), porém, em face da disposição do aludido artigo 38, o consumidor deixa de estar onerado, e é o fornecedor quem deve provar que a publicidade não apresenta qualquer irregularidade.

Além da hipótese supra, também podemos identificar outras hipóteses de redistribuição legal do ônus da prova nos artigos 12 e 14 do Código de Defesa do Consumidor.

DÉBORA DE OlIVEIRA RIBEIRO defende que essa redistribuição, embora aparentemente implícita, consiste na imposição ao fornecedor, diante da alegação de defeito no produto ou serviço, do ônus de provar que, tendo colocado o produto no mercado ou prestado o serviço, o defeito não existe $\left(\S 3 .^{\circ}\right.$, inciso II, do artigo 12 e $\S 3 .^{\circ}$, inciso I, do artigo 14). ${ }^{241}$

Para ARTUR CARPES, trata-se, em verdade, de presunção iuris tantum acerca da existência do defeito, ${ }^{242}$ o que retiraria do consumidor o ônus de provar a existência ou a ocorrência do vício no produto ou no serviço.

Em nossa opinião, a hipótese é mesmo de deslocamento do ônus probatório, e não de presunção relativa, pois falta o elemento fundamental desta, consistente na constatação do fato a ser provado (factum probandum) a partir de um indício ou fato probante (factum probans), com base no raciocínio do juiz e nas regras de experiência. De fato, não nos parece razoável tomar como indício que, em regra, os produtos e serviços

241 Inversão do ônus da prova no Código de Defesa do Consumidor. 2005. Dissertação (Mestrado em Direito) - Faculdade de Direito, Universidade de São Paulo, São Paulo. Em sua dissertação a autora sustenta que a redistribuição judicial do ônus da prova também ocorreria para as hipóteses dos incisos I e III do $\S 3 .^{\circ}$ do artigo 12 e para a hipótese do inciso II, do $\S 3 .^{\circ}$, do artigo 14 , com o que não concordamos, pois tratam, em verdade, de fatos extintivos do direito do consumidor, quais sejam: a não colocação do produto no mercado e a ocorrência de culpa exclusiva do consumidor ou terceiro, fatos estes que têm o condão de romper o nexo de causalidade entre suposto defeito do produto ou serviço e a obrigação de indenizar o consumidor, e que devem ser alegados na defesa do fornecedor, inexistindo qualquer redistribuição da regra geral prevista no artigo 333 do Código de Processo Civil. 
disponibilizados ao público são defeituosos e a simples alegação de que o consumidor adquiriu certo produto ou serviço lhe impõe a "pecha" de defeituoso. ${ }^{243}$

A corroborar nosso posicionamento, é certo que, pela regra geral de distribuição do ônus da prova, o consumidor que alega ter sofrido danos em decorrência de defeito em produto ou serviço adquirido de determinado fornecedor deve provar os fatos constitutivos do seu direito (a aquisição do produto ou serviço, o defeito e o dano). Já pela regra do Código de Defesa do Consumidor, esse consumidor não precisará fazer prova de pelo menos um dos fatos constitutivos, qual seja o defeito no produto ou serviço, cujo ônus da prova é transferido, ope legis, ao fornecedor, o qual deverá provar que o produto ou serviço não apresenta o defeito alegado pelo consumidor.

Por se tratar de previsão legal de distribuição diferenciada do ônus da prova, o magistrado não necessitará fazer qualquer advertência ou proferir qualquer decisão interlocutória no curso do processo para se valer, eventualmente, de tal regra de atribuição de ônus probatórios no momento de sentenciar. Ou seja, o processo já se inicia com o ônus "redistribuído". Na verdade, nessa hipótese, a distribuição do ônus da prova é atribuída previamente de forma diferenciada por regra especial (Código de Defesa do Consumidor) que deve prevalecer sobre a regra geral prevista no Código de Processo Civil, não havendo falar em qualquer redistribuição ou mesmo distribuição dinâmica.

\subsection{Hipótese de redistribuição judicial do ônus da prova}

\subsubsection{Características fundamentais}

Além das hipóteses de redistribuição legal supramencionadas, o artigo $6^{\circ}{ }^{\circ}$, inciso VIII, do Código de Defesa do Consumidor, ao tratar dos direitos básicos do consumidor, prevê a possibilidade de redistribuição do ônus da prova em favor do consumidor para "facilitação da defesa dos seus direitos", "quando, a critério do juiz, for

243 Ainda que grande parte dos produtos e serviços, principalmente aqueles oferecidos em massa, nem sempre tenha o padrão de qualidade desejado, isso não importa em admitir que sejam sempre defeituosos. Pelo contrário. A constatação que se faz, em um exame mesmo sem qualquer embasamento científico, é que a maioria dos produtos e serviços funciona e apenas ocasionalmente apresenta algum tipo de defeito, de modo que essa situação deve ser tida como a exceção, e não a regra. 
verossímil a alegação ou quando for ele hipossuficiente, segundo as regras ordinárias da experiência". 244

O objetivo dessa regra não é outro senão permitir ao consumidor amplo acesso ao Poder Judiciário, ainda que impossibilitado de, por suas próprias forças, produzir a prova de suas alegações, em especial diante de sua "ignorância" quanto a determinados fatos que dentro da cadeia produtiva de bens e serviços apenas o fornecedor conhece plenamente.

\subsubsection{Requisitos condicionantes ao emprego da técnica de redistribuição do ônus da prova}

Para que o consumidor faça jus à redistribuição do ônus no caso concreto, a Lei prevê dois requisitos: a verossimilhança das alegações e a hipossuficiência do consumidor, ${ }^{245}$ a serem analisadas pelo juiz pelas regras ordinárias da experiência, ou seja, de acordo com aquilo que normalmente acontece.

Não obstante o uso da conjunção alternativa "ou" no texto legal, filiamo-nos à corrente doutrinária que interpreta o citado dispositivo como uma cumulação, exigindo-se que ambos os requisitos sejam demonstrados para que ocorra a pretendida redistribuição do ônus da prova. ${ }^{246}$

244 Como bem observa ANTONIO GIDI, a redistribuição judicial é um direito do consumidor e, portanto, um dever do juiz, pois "não diz a lei que fica 'a critério do juiz' inverter o ônus da prova. O que fica 'a critério do juiz' (rectius, a partir do seu livre convencimento motivado) é a tarefa de aferir no caso concreto levado à sua presença, se o consumidor é hipossuficiente e se sua versão dos fatos é verossímil" (Aspectos..., cit., p. 36).

Além dos requisitos legais, deve-se ter presente que a redistribuição do ônus da prova somente será viável se a prova a ser buscada seja possível de ser produzida. Se sua produção é impossível tanto para o autor consumidor como para o réu fornecedor (probatio diabolica), não assiste razão ao juiz querer promover a redistribuição do ônus. Nesse sentido, CARMELA DELL'ISOLA afirma que "não bastam os dois requisitos apontados, mas a inversão do ônus da prova somente pode ser admitida quando o fornecedor tiver a possibilidade de produzir a prova" ( $O$ ônus..., cit., p. 95). Como já ressaltamos no item "3.2" do Capítulo 3, não há que falar em distribuição do ônus da prova para os fatos que simplesmente não podem ser provados, pois o ônus, como espécie do gênero faculdades processuais, deve ser possível de ser desincumbido. Voltaremos a tratar do tema quando discorrermos sobre os requisitos para a aplicação da técnica de distribuição dinâmica do ônus da prova (vide item "5.3" e subitens do Capítulo 5). que, "embora o texto legal fale nominalmente em verossimilhança ou hipossuficiência, a leitura 
A verossimilhança ${ }^{247}$, como vimos no item "1.4" do Capítulo 1, é apurada a partir daquilo que tem aparência de verdade, que ao menos em um exame perfunctório demonstra uma possibilidade de ser verdade, cuja análise será realizada pelo juiz a partir das regras de experiência e das presunções simples. ${ }^{248}$

O requisito da hipossuficiência consiste na fragilidade técnica e informativa do consumidor em relação aos fatos relevantes para a solução do litígio, e não eventual desigualdade econômica, como originalmente defendido. ${ }^{249}$

Também não se deve confundir hipossuficiência com vulnerabilidade. ${ }^{250}$ Esta é presumida e decorre da mera condição de consumidor. ${ }^{251}$ A proteção que se pretende dar

correta deve substituir o disjuntivo ou pelo aproximativo $e$, porque a leitura nominal implicaria inconstitucionalidade do texto: a) favorecer o consumidor abastado transgrediria a garantia da igualdade, ainda quando verossímil o que alega, porque sem o requisito da pobreza não há desigualdades a compensar; b) favorecer o consumidor, rico ou pobre, sem que sua alegação seja verossímil, fecharia ou estreitaria sem motivo a via de acesso à ordem jurídica justa, em relação ao produtor, sujeitando-o aos azares de uma probatio diabolica" (Instituições..., cit., v. 3, p. 80). No mesmo sentido: ANTONIO GIDI (Aspectos..., cit., p. 34). Defendendo a alternatividade dos requisitos, temos, entre outros, NELSON NERY JUNIOR (Aspectos..., cit., p. 218), e CARLOS RobERTO BARBOSA MOREIRA (Notas..., cit., p. 141).

A verossimilhança exigida para o deslocamento do ônus da prova não se confunde com a "verossimilhança" que se exige para os casos de antecipação de tutela do artigo 273 do Código de Processo Civil ou de medidas cautelares, pois em tais circunstâncias haveria necessidade de comprovação da probabilidade, estágio mais avançado de convencimento. Sobre a distinção, vide o que dispusemos no item "1.4" do Capítulo 1. Alguns autores, por seu turno, tentam associar a verossimilhança prevista na norma consumerista ao requisito do fumus boni iuris do pedido cautelar, como José CARlos Maldonado de CARVAlho (A inversão..., cit., p. 248), com o que não concordamos, pois aqui, mais uma vez, vale o requisito da probabilidade e ali o da possibilidade.

248 Como leciona CECÍlIA MATOS, “a presunção é um raciocínio lógico utilizado para que, de um fato conhecido (o indício), seja possível chegar a um fato também desconhecido. A regra de experiência é também um processo lógico, baseado em fatos comuns, preexistentes, genéricos e abstratos do conhecimento humano, de uso corriqueiro pelo juiz. Assim, analisando as provas do processo, aplicará o julgador às presunções e regras de experiência, onde poderá presumir a verossimilhança da existência de um direito alegado não provado, a partir do indício. Por meio do raciocínio lógico, o juiz poderá entender que um fato, apesar de não comprovado, reveste-se de alta dose de probabilidade, se inexistir qualquer prova do adversário que contrarie a presunção" (O ônus..., cit., p. 165).

Nas primeiras edições do Código brasileiro de Defesa do Consumidor comentado pelos autores do anteprojeto, KAZUO WATANABE defendia que a hipossuficiência prevista na norma era apenas a econômica, equivalente àquela prevista na Lei n. ${ }^{\circ}$ 1.060/1950, mas reviu sua posição para qualificar a hipossuficiência como uma "diminuição da capacidade do consumidor, não apenas no aspecto econômico, mas a social, de informações, de educação, de participação, de associação, entre outros" (Código..., cit., 714).

250 Como ressalta FERNANDA TARTUCE, “[...] Vulnerabilidade e hipossuficiência não retratam idênticos conceitos. [...] Vulnerabilidade indica, assim, suscetibilidade em sentido amplo, sendo a hipossuficiência uma de suas espécies - vulnerabilidade econômica" (Igualdade e vulnerabilidade no processo civil. Rio de Janeiro: Forense, 2012. p. 183). Para a referida autora, sempre que houver limitações econômicas e técnicas de produção probatória que inviabilizem o acesso à justiça do consumidor, ele merece ver reconhecida a redistribuição do ônus da prova.

251 HENRY FORD, o pai dos meios de produção em série, já prelecionava que "o consumidor é o elo mais fraco da economia; e nenhuma corrente pode ser mais forte do que seu elo mais fraco" (RÓNAI, 
ao consumidor com a redistribuição do ônus da prova é no tocante às informações inerentes ao produto ou serviço, as quais, em regra, o consumidor não teria acesso, seja pela sua complexidade, seja pela confidencialidade ou exclusividade mantida pelo fornecedor, o que impede o acesso do consumidor a essas informações. ${ }^{252}$

Há, portanto, hipossuficiência quando constatada uma assimetria de informações $^{253}$ entre o consumidor e o fornecedor. Este com total domínio das informações, e, portanto, com ampla capacidade probatória em relação a tais fatos, e aquele desprovido de informações, e, por conseguinte, com capacidade probatória reduzida ou mesmo inexistente em relação a tais fatos.

Presentes os requisitos, o juiz deverá aplicar a redistribuição do ônus da prova, mas essa não é ilimitada, abrangendo a prova de todas as alegações do autor. Inicialmente, faz-se necessário que o fato tenha se tornado controvertido, e a seguir devem ser fixados os fatos em que há hipossuficiência do consumidor, como já ressaltamos no item "4.2" deste Capítulo.

Imaginemos a hipótese de um consumidor que sofre de uma determinada doença e promove uma ação reparatória contra a fabricante de certo remédio que vem consumindo nos últimos anos, sob a alegação de que foi o remédio que lhe causou a doença, inexistente antes do consumo deste, e que os danos decorrentes são da ordem de um milhão de reais. $\mathrm{O}$ autor, por certo, não detém conhecimento sobre os meios de fabricação do remédio e dos efeitos que ele pode produzir no organismo humano, salvo se atuar profissionalmente nesse mercado.

Paulo. Dicionário universal de citações apud GRINOVER, Ada Pellegrini et al. Código..., cit., p. 54). Enfatizando a condição de submissão, na definição de FÁBIO KONDER COMPARATO, "consumidor é, pois, de modo geral, aquele que se submete ao poder de controle dos titulares de bens de produção, isto é, os empresários" (A proteção do consumidor. Revista de Direito Mercantil, Industrial, Econômico e Financeiro, São Paulo: RT, n. 15, p. 90, 1974).

252 "Note-se que nas relações de consumo a solução da demanda depende, muitas vezes, de conhecimento de informações de natureza técnica que só o fornecedor dispõe. Não seria razoável exigir que a parte contrária, que não detém o poder de informação, recebesse o encargo de provar questões relativas a conhecimento ao qual não tem acesso. É mais justa a solução dada pelo ordenamento, cabendo ao demandado, detentor da informação privilegiada ou específica, o encargo de provar que o evento se dá de forma diversa da sustentada pelo demandante, pois só aquele detém os informes precisos quanto ao tema debatido em juízo, objeto da prova" (LEONEL, Ricardo de Barros. Manual do processo coletivo. São Paulo: RT, 2002. p. 337).

253 A terminologia "assimetria de informações" é utilizada por HEITOR SICA para designar a hipossuficiência técnica do consumidor, ligada à ideia de posse de conhecimento e de informação, que nas relações de consumo está concentrada nas mãos do fornecedor (Questões velhas..., cit., p. 51-52). 
Nesse caso, deverá o juiz exigir da indústria farmacêutica responsável pela produção e comercialização do remédio a realização da prova quanto à inexistência de nexo causal entre o consumo do referido remédio e a alegada doença contraída pelo consumidor, pois é a empresa que pode fornecer as informações adequadas sobre a fabricação e a qualidade do produto, inclusive provando que o remédio causa a doença contraída pelo consumidor.

Já em relação à prova do efetivo consumo do remédio e do montante do dano, por certo que o ônus caberá, sempre, ao consumidor, pois em relação a tais fatos inexiste hipossuficiência. Pelo contrário, é de imaginar que o consumidor encontra-se em situação privilegiada de provar a aquisição e consumo do remédio, seja por prescrição médica ou notas fiscais de compra do remédio, e o montante dos danos que entende decorrentes da doença.

Logo, concluímos que o cabimento da redistribuição judicial do ônus da prova prevista no Código de Defesa do Consumidor deve ser avaliado pelo juiz à luz do caso concreto, analisando se estão presentes os requisitos e delimitando em relação a que alegações de fato a redistribuição deve ser aplicada, não sendo admissível uma redistribuição ampla e indiscriminada, a pretexto de facilitação da defesa do consumidor.

Frise-se, redistribui-se o ônus para suprir eventual desigualdade material entre as partes, e não para garantir o êxito da demanda promovida pelo consumidor.

O juiz deve sempre agir com parcimônia e coerência na aplicação da técnica de redistribuição do ônus da prova, sobretudo para evitar a hipótese de prova diabólica para o fornecedor, o que resultaria na definição do resultado do processo não com base na apuração da realidade dos fatos, mas em um critério torpe de "justiça", à luz de uma distorcida regra de julgamento.

Para se evitar tal situação, é essencial que, antes da aplicação da técnica de redistribuição do ônus da prova, seja bem examinada a presença dos requisitos ora descritos, bem como seja oportunizado à parte que se tornar onerada (fornecedor) se desincumbir de tal ônus, como veremos no próximo item. 


\subsubsection{Momento e limites da aplicação da redistribuição judicial do ônus da prova}

A doutrina se divide em três grandes correntes quanto à definiçãa do momento em que deve ocorrer a redistribuição judicial do ônus da prova prevista no inciso VIII do artigo 6. ${ }^{\circ}$ do Código de Defesa do Consumidor, quais sejam: (i) ao despachar a inicial; (ii) até a fase instrutória (atuando como uma regra de conduta); e (iii) na sentença (atuando como uma regra de julgamento). ${ }^{254}$

Para os defensores da distribuição do ônus da prova como uma regra de conduta, o momento da redistribuição judicial do ônus da prova deve ocorrer preferencialmente antes do início da fase instrutória, oportunizando às partes, já cientes dos respectivos ônus, a produção probatória. ${ }^{255}$

Como visto anteriormente, a regra de distribuição do ônus da prova tem amparo no princípio da igualdade, em que as partes duelam em paridade de condições, mas nos processos que envolvem relação de consumo esse equilíbrio entre as partes inexiste, pois o consumidor é presumidamente vulnerável e eventualmente hipossuficiente, exigindo-se o uso de mecanismos excepcionais para se restabelecerem as forças entre as partes. $^{256}$

Contudo, essa isonomia pretendida com a inversão do ônus da prova deve ser sopesada com outras garantias constitucionais, sobretudo com o contraditório e a ampla defesa, caracterizados pelo binômio "acesso à informação" e "oportunidade de reação", ${ }^{257}$

254 Em relação à primeira corrente (redistribuição ao despachar a petição inicial), sustentada por DELL'ISOLA ( $O$ ônus..., cit., p. 100-101), parece-nos descabida pelo simples motivo de que nessa fase processual o juiz sequer sabe quais fatos se tornarão controvertidos e necessitarão ser provados, pois ainda inexiste manifestação do réu. TÂNIA LIS TIZZONI NOGUEIRA, que também defendia essa posição, em obra mais recente reviu sua posição e hoje admite que o momento ideal para o juiz proclamar a redistribuição seja entre o despacho inicial até o despacho saneador (A prova..., cit., p. 127-128). As outras duas correntes serão examinadas com mais detalhe no curso do texto.

255 Com esse entendimento, encontramos as lições de ANTONIO GIDI (Aspectos..., cit., p. 39), PAULO HofFMAN (Inversão..., cit., p. 234), TERESA ARRUdA AlviM WAMBIER (Noções gerais..., cit., p. 256) e CARLOS RoBERTO BARBOSA MoReIRA (Notas..., cit., p. 306), entre outros.

256 Como adverte SÁ DOS SANTOS, “os cidadãos devem ter à sua disposição instrumentos processuais para a concreta efetividade da tutela dos seus direitos, motivo que, só por si, torna imprescindível a aplicação do instituto da inversão do ônus da prova, em qualquer relação jurídica de natureza civil, como garantia constitucional do devido processo legal" (A inversão do ônus da prova. 2. ed. São Paulo: RT, 2006. p. 99).

257 CINTRA, Antonio Carlos de Araújo; GRINOVER, Ada Pellegrini; DINAMARCO, Cândido Rangel. Teoria geral do processo. 17. ed. São Paulo: Malheiros, 2001. p. 57. 
sem prejuízo da sua função influenciadora sobre o convencimento judicial e a decisão final a ser proferida pelo juiz. ${ }^{258}$

Assim, para que o fornecedor possa exercer plenamente o contraditório e defender-se adequadamente, faz-se necessário que a redistribuição do ônus da prova ocorra antes da fase instrutória, permitindo que o fornecedor produza as provas de que foi incumbido. $^{259}$

Na lição de Voltaire De Lima MoRAES,

[...] o momento adequado para a decretação da inversão do ônus da prova dar-seá por ocasião do saneamento do processo, quando inexitosa a audiência de conciliação, o juiz tiver fixado os pontos controvertidos, aí sim, em seguimento, decidirá as questões processuais pendentes, dentre as quais o cabimento ou não da inversão do ônus da prova (art. 331, § $2 .^{\circ}$, do CPC), ficando dessa forma cientes as partes da postura processual que passarão a adotar, não podendo alegar terem sido surpreendidas, especialmente aquela que recebeu o encargo de provar. $^{260}$

Para Luiz Guilherme MARINONi e SÉRgio CruZ AREnHART, “a inversão do ônus da prova se destina a dar ao réu a oportunidade de produzir a prova que, de acordo com a regra do art. 333, incumbiria ao autor", transferindo "do autor ao réu o ônus de produzi-la - o que deve ser feito na audiência preliminar". ${ }^{261}$

A principal crítica formulada contra a redistribuição do ônus da prova antes do início da fase instrutória reside em retirar da regra de distribuição do ônus da prova a sua essência, ${ }^{262}$ consistente em definir como o juiz deve julgar diante da ausência ou

258 Essa concepção do contraditório como "direito de influência" é sustentada, com já vimos, por ANTONIO DO PASSO CABRAL, para quem "[...] la comprensione del contraddittorio come diritto di influenza esprime la democrazia deliberativa nel processo: la società può influenzare gli atti decisori statali con la discussione argomentativa, ed il contraddittorio è il principio processuale che mette in pratica questo procedimento dialogico, aprendo il palco giurisdizionale al dibattito partecipativo e pluralista" (Il principio del contraddittorio come diritto d'influenza e dovere di dibattito. Rivista di Diritto Processuale, Padova, v. 60, n. 2, p. 456, apr.-giug. 2005).

259 TARUFFO é enfático quanto à necessidade de se permitir à parte onerada a tentativa de produzir a prova. Quando a distribuição do ônus da prova é modificada apenas na decisão final e tomada como razão de decidir, de acordo com o autor italiano, "são violadas as mais elementares regras do contraditório, com base nas quais as partes deveriam conhecer in anticipo e em tempo útil os critérios aos quais deveriam ater-se na predisposição de suas iniciativas probatórias" (O ônus como figura processual...., cit., p. 427-428).

260 Anotações..., cit., p. 69.

261 Prova. São Paulo: RT, 2009. p. 196.

262 DinAMARCo sustenta que o momento para o juiz inverter o ônus da prova é o “[...] de julgar a causa, pois antes não se conhecem os resultados mais conclusivos ou menos conclusivos a que a instrução probatória conduzirá [...]" (Instituições... cit., v. 3, p. 84), porém pondera que "isso não significa que, 
insuficiência de provas para emissão de um juízo de certeza ou, ao menos, de probabilidade (função objetiva do ônus da prova).

Esse argumento nos parece falho pelo simples fato de ignorar a existência da função subjetiva do ônus da prova e sua importância como técnica de descoberta da verdade, como procuramos demonstrar no item "2.3.1” e na conclusão do Capítulo 2.

Com efeito, os críticos alegam que seria impossível a redistribuição antes da sentença porque a regra de distribuição do ônus da prova é uma regra de julgamento a ser aplicada pelo juiz quando do instrumento probatório não for possível extrair o seu convencimento. Entretanto, o ônus da prova deve (sempre) ser analisado sob a ótica subjetiva e objetiva, e toda modificação na distribuição do ônus da prova deve possibilitar à parte se desonerar, sob o risco de perder sua característica fundamental, que é a faculdade da parte entre agir ou não agir, por sua livre escolha, bem como a certeza de ofensa ao contraditório e à ampla defesa.

Outra objeção que se faz a essa corrente é a de que o juiz, ao emitir um juízo antes de encerrada a fase instrutória, estaria prejulgando a demanda, de maneira parcial e precipitada, ${ }^{263}$ antes mesmo de ser capaz de formar o seu convencimento.

Também não acolhe razão esse argumento, pois, como bem observa CARLOS ROBERTO BARbOSA Moreira, "a facilidade da norma que prevê a inversão é a de facilitar a defesa dos direitos do consumidor, e não a de assegurar-lhe a vitória [...]", ${ }^{264}$ de modo que, se bem observados os requisitos e condicionantes, não se define o resultado do processo com a redistribuição do ônus da prova, mas apenas ampliam-se o arcabouço probatório e as chances de aclaramento dos fatos relevantes para o julgamento, que continuará sendo realizado com base no livre convencimento motivado do magistrado, e

antes do momento de julgar, a disciplina do ônus da prova seja destituída de relevância no processo" (Instituições... cit., v. 3, p. 83), devendo o juiz advertir as partes sobre os respectivos ônus e a possibilidade de sua redistribuição na audiência preliminar. HEITOR SICA também adota como correta a postura de o juiz "avisar" as partes sobre a possibilidade da redistribuição, mas desde que as partes não tenham renunciado ao direito a outras provas e o juiz não seja capaz de obter de ofício outros elementos probatórios (Questões velhas..., cit., p. 62-64). 
apenas excepcionalmente com base na regra de distribuição do ônus da prova (normal ou redistribuída), dependente da alegação de fato que não restou devidamente provada.

Outrossim, o resultado do esforço probatório é incerto, sendo possível a parte que se tornou incumbida conseguir produzir os elementos de prova ou não, de forma que a mera determinação sobre quem terá o ônus da produção da prova não é capaz de vincular o julgador a um determinado resultado ou torná-lo imparcial.

Argumenta-se, ainda, que o fornecedor não poderia alegar ignorância da lei como fundamento para sua inércia na produção de determinada prova que por força da redistribuição lhe foi imposta apenas na sentença. ${ }^{265}$

Mais uma vez, entendemos que a crítica não se sustenta. Como já analisamos, a redistribuição do ônus da prova prevista no inciso VIII do artigo $6 .^{\circ}$ do Código de Defesa do Consumidor opera-se ope judicis, ou seja, depende de decisão motivada do juiz, na qual revela expressamente a presença dos requisitos autorizadores da redistribuição..

Trata-se de uma exceção à regra geral e abstrata de distribuição do ônus da prova, atribuindo a quem não tinha originalmente o ônus da prova esse encargo (ainda que sobre outra alegação de fato), e liberando desse ônus aquele que a lei previa como seu titular, não podendo ser aplicada apenas na sentença, sob pena de ferir o contraditório e a ampla defesa. $^{266}$

Em sentido oposto, parte da doutrina sustenta a tese de que a redistribuição do ônus da prova nas ações envolvendo relações de consumo deve ocorrer apenas na sentença, após a constatação de ausência ou insuficiência de prova para formação do convencimento acerca das alegações de fato formuladas pelo consumidor e que admitem a redistribuição, oportunidade em que o magistrado deverá averiguar a ocorrência ou não dos requisitos ensejadores da modificação do ônus da prova, e, se presentes, julgar a ação de acordo com a regra redistribuída de distribuição do ônus da prova.

\footnotetext{
265 O argumento, mais uma vez, é trazido por CECÍlí MATOS (O ônus..., cit., p. 167).

266 Conforme lecionam LuIZ GUILHERME MARINONI e SÉRGIO CRUZ ARENHART, "se a parte tem o direito de adequadamente participar do processo, ele evidentemente não pode ter uma sentença que lhe é contrária formada em virtude da sua inércia, quando originalmente, de acordo com a regra comum do ônus da prova, a prova não seria da sua incumbência" (Comentários ao Código de Processo Civil. 2. ed. São Paulo: RT, 2005. v. 5, p. 197).
} 
O fundamento central dessa doutrina consiste em tratar a distribuição do ônus da prova e eventuais hipóteses de redistribuição apenas como uma regra de julgamento, focando, portanto, apenas a função objetiva do ônus da prova. ${ }^{267}$ Assim, qualquer insurgência relacionada ao ônus da prova deve ser levada em consideração pelo juiz apenas quando ele verificar a ausência ou a insuficiência da prova no momento de proferir a sentença. $^{268}$

As críticas destinadas a este pensamento, as quais corroboramos integralmente, fundamentam-se, essencialmente, na insegurança jurídica gerada em decorrência da falta de orientação e na tomada de uma decisão surpresa, bem como no inquestionável cerceamento do direito de defesa, pois o fornecedor sofrerá os efeitos negativos da não desincumbência de um ônus que originalmente não possuía e que lhe foi imposto sem qualquer possibilidade de dar cumprimento. ${ }^{269}$

Em contrapartida, os defensores da incidência da técnica prevista no inciso VIII do artigo 6. ${ }^{\circ}$ do Código de Defesa do Consumidor apenas no momento do julgamento, se persistir o estado de dúvida, alegam que não haveria qualquer surpresa ao fornecedor, haja vista que este já tem conhecimento prévio sobre a possibilidade de redistribuição do ônus da prova, desde que presentes os requisitos no caso concreto, os quais são do seu conhecimento. $^{270}$

267 Acolhendo esse posicionamento encontramos KaZuo Watanabe (Código..., cit., p. 735), CeCília MATOS (O ônus..., cit., p. 167), DinAMARCO (Instituições..., cit., v. 3, p. 83) e ERNANE FIDÉLIS DOS SANTOS (O ônus..., cit., p. 278), entre outros.

268 JOÃo BATISTA LOPES é enfático ao afirmar que “[...] é orientação assente na doutrina que o ônus da prova constitui regra de julgamento e, como tal, se reveste de relevância apenas no momento da sentença, quando não houver prova do fato ou for ela insuficiente. Diante disso, somente após o encerramento da instrução é que se deverá cogitar da aplicação da regra da inversão do ônus da prova". (A prova..., cit., p. 51).

269 Como adverte CARlos Roberto BARbosa Moreira, "a inversão, se ordenada na sentença, representará, quanto ao fornecedor, não só a mudança da regra geral até ali vigente, naquele processo, como também algo que comprometerá sua defesa, porquanto, se lhe foi transferido um ônus - que para ele não existia antes da adoção da medida -, obviamente deve o órgão jurisdicional assegurar-lhe a efetiva oportunidade de dele se desincumbir. Não só. A aplicação do dispositivo em exame, se observada a orientação doutrinária aqui combatida, redundaria em manifesta ofensa aos princípios do contraditório e da ampla defesa ( $\mathrm{CF}$, art. $\left.5^{\circ}, \mathrm{n}^{\circ} \mathrm{LV}\right)$. Ao mesmo tempo em que estivesse invertendo o ônus da prova, o juiz já estaria julgando, sem dar ao fornecedor a chance de apresentar novos elementos de convicção, com os quais pudesse cumprir aquele encargo". (Notas..., cit., p. 306).

270 Esse argumento é de CECÍLIA MATOS, PARA QUEM “[....]o fornecedor pode realizar todo e qualquer tipo de prova, dentre aquelas permitidas em lei, durante a instrução para afastar a pretensão do consumidor. Se o demandado, fiando-se na suposição de que o juiz não inverterá as regras do ônus da prova em favor do demandante, é surpreendido com uma sentença desfavorável, deve creditar o seu insucesso mais a um excesso de otimismo do que a hipotética desobediência ao princípio da ampla defesa". (O ônus..., cit., p. 167). 
Não obstante os fundamentos favoráveis e contrários, entendemos que a redistribuição do ônus da prova determinada apenas na sentença fica fragilizada por considerar somente a função objetiva do ônus da prova, ignorando a sua faceta subjetiva, e, ainda assim, de forma um pouco oblíqua, pois confunde regras de naturezas distintas.

A discrepância e a rigidez dos defensores das duas correntes majoritárias sobre o momento da redistribuição do ônus da prova residem, em nosso sentir, na confusão entre a natureza da norma que define a repartição do ônus da prova (artigo 333 do Código de Processo Civil) e da norma que define a redistribuição do ônus da prova (artigo $6 .^{\circ}$, inciso VIII, do Código de Defesa do Consumidor).

ANTONIO GIDI bem destacou essa divergência conceitual entre as mencionadas regras processuais, advogando que, se é certo que a regra de distribuição do ônus da prova é necessariamente uma "regra de juízo", o mesmo não se pode dizer em relação à norma que prevê a redistribuição do ônus da prova, que é eminentemente uma "regra de atividade". 271

A regra de distribuição prevista no artigo 333 do Código de Processo Civil informa as partes sobre os seus respectivos ônus e salvaguarda o juiz em caso de dúvida.

No Capítulo 2 tivemos a oportunidade de demonstrar que o ônus da prova tem dupla função: persuasiva para obtenção do êxito e influenciadora do comportamento das partes (função subjetiva) e jurisdicional para o juiz em caso de dúvida (função objetiva). É uma regra legal geral e abstrata, de conhecimento prévio das partes (ou ao menos de seus respectivos advogados), que as orienta tanto no plano pré-processual como processual, não sendo possível às partes se escusar de suas consequências sob a alegação de desconhecimento.

271 Aspectos..., cit., p. 38. CARLOS ALBERTO DE SALLES também percebe essa desnaturação das regras de distribuição do ônus da prova, observando que "a norma geral e abstrata de distribuição serve para orientar o julgamento da causa, mas serve, também, para guiar a iniciativa probatória das partes e, em momentos antecedentes, a própria propositura da ação - ou até mesmo o cumprimento voluntário da obrigação por parte do réu. Assim, perdendo a fixação do ônus da prova seu caráter geral, abstrato e, portanto, prévio ao processo, para ser estabelecido ope judicis, de acordo com as circunstâncias do processo, impossível considerá-lo exclusivamente como regra de julgamento, sob pena de se estar exigindo das partes o atendimento de um ônus para o qual elas não haviam sido alertadas, ainda não estabelecido" [Transição paradigmática na prova processual civil. In: ASSIS, Araken de et al. (Coord.). Direito civil e processo: estudos em homenagem ao Professor Arruda Alvim. São Paulo: RT, 2007. p. 919]. 
De fato, a ideia de distribuir o ônus é "sancionar" quem tinha a oportunidade de realizar o ato (conforme previamente determinado em lei) e não o fez, servindo, ao final, como uma regra para o juiz se pronunciar diante da impossibilidade do non liquet.

Essa dupla face da regra de distribuição do ônus da prova também se apresenta na redistribuição do ônus da prova? A resposta nos parece negativa.

A regra de redistribuição judicial do ônus da prova, prevista no inciso VIII do artigo $6{ }^{\circ}$ do Código de Defesa do Consumidor, deve ser entendida como uma técnica de atribuição diferenciada do ônus da prova, para que a prova seja produzida pela parte com maior capacidade probatória, sempre visando o reequilíbrio das forças das partes, e, no caso específico dos processos envolvendo relação de consumo, para a facilitação da defesa do consumidor em juízo.

Sua função primordial, portanto, é estruturar a produção de provas pertinentes ao deslinde da controvérsia consumerista, e não sancionar quem deixou de provar determinados fatos, pois, nessa hipótese, seria mesmo de se cogitar a imparcialidade do julgador, uma vez que a redistribuição opera-se em sentido único, ou seja, como função objetiva somente sanciona o fornecedor, que é o único que pode receber mais ônus do que originalmente previsto.

Como vimos, a razão de ser da redistribuição do ônus é tentar eliminar a assimetria entre as "capacidades" de o consumidor e o fornecedor produzirem as provas, "sob pena de se permitir vantagem indevida para a parte detentora da informação ou dos recursos tecnológicos", como ressalta SALLES. ${ }^{272}$

Não se pretende que o consumidor seja vitorioso em toda e qualquer demanda, mas apenas facilitar sua defesa em juízo.

Desse modo, a regra da redistribuição somente é aplicável se preenchidos os requisitos anteriormente analisados da verossimilhança e hipossuficiência, assim como não implique em prova diabólica para o fornecedor, e desde que haja decisão judicial motivada

272 Transição..., cit., p. 919. 
a respeito. Ou seja, a redistribuição não se opera automaticamente, não obstante possa ser declarada de ofício, independentemente de pedido expresso do consumidor.

Como técnica de exceção condicionada à apreciação judicial, por certo que não seria possível pressupor a sua ocorrência, de forma que, sob a ótica subjetiva do ônus da prova, a parte deve se atentar à regra geral e somente excepcionalmente se submeter a outro modo de agir, desde que ordenada pelo juiz, e sempre com a possibilidade de se manifestar previamente.

Nesse sentido é a lição de Teresa Arruda Alvim Wambier, para quem, em regra, a redistribuição deverá ocorrer antes da fase instrutória, mas, mesmo que assim não o faça, se o juiz perceber após toda a produção probatória que se encontravam presentes os requisitos para a redistribuição do ônus e que há questões fáticas não provadas, deve o juiz aplicar a técnica da lei consumerista, imputando o ônus da prova ao fornecedor, reabrindo a fase instrutória para possibilitar ao fornecedor a produção da(s) prova(s) pertinente(s). ${ }^{273}$

Apenas se for oportunizada a produção da prova (com ou sem redistribuição) e ainda assim o estado de dúvida permanecer, daí cabe ao juiz decidir conforme a regra de distribuição do ônus da prova, impondo uma sentença desfavorável à parte que não se desincumbiu do seu ônus previamente distribuído, seja com base na regra geral e abstrata, seja com base na regra redistribuída em momento prévio do processo.

Procurando acabar com essa divergência quanto ao momento de incidência de distribuição do ônus da prova e sua redistribuição, o projeto do novo Código de Processo Civil, em seu artigo 354, estabelece as providências a serem adotadas na "decisão de saneamento e de organização do processo", estabelecendo no inciso III que caberá ao magistrado "definir a distribuição do ônus da prova, observado o art. 370”, o qual, como veremos adiante, trata das regras abstrata e dinâmica de distribuição do ônus da prova, devendo ser aplicado subsidiariamente nas ações que envolvem relação de consumo.

273 Noções gerais..., cit., p. 256. Com a mesma opinião, ANTONIO GIDI (Aspectos..., cit., p. 39). O projeto do Código de Processo Civil, ao prever a possibilidade de distribuição dinâmica, atribuindo, excepcionalmente, o ônus da prova à parte que demonstrar melhores condições de produzi-la, é expresso sobre a necessidade de dar oportunidade à parte que se tornar onerada pela decisão de

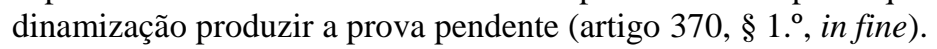


Diante de tais motivos, forçoso concluir que a técnica de redistribuição do ônus da prova atua como um mecanismo de eliminação de desigualdades entre as partes em litígio, devendo operar-se no curso do processo, preferencialmente, antes do início da fase instrutória (na "decisão de saneamento e de organização do processo"), para que a parte onerada possa valer-se dos meios probatórios para se desincumbir do ônus excepcionalmente assumido.

Se, contudo, os requisitos autorizadores da redistribuição somente se mostrarem presentes no momento do julgamento, entendemos que deverá o julgador declarar a modificação do ônus da prova e facultar ao fornecedor produzir a prova que lhe foi incumbida, para somente depois, permanecendo a dúvida, decidir conforme a regra de distribuição (normal ou redistribuída) do ônus da prova.

\subsubsection{Redistribuição do ônus da prova e adiantamento das despesas processuais}

Uma questão que intriga doutrina e os tribunais é a definição da parte onerada pela antecipação das despesas processuais concernentes à prova a ser realizada quando há redistribuição do ônus da prova. O ponto central é saber se a parte originalmente onerada continua responsável pelo pagamento das despesas ou se com a redistribuição também se modificaria o ônus financeiro da prova.

Uma primeira corrente sustenta que a redistribuição do ônus de provar não implica a assunção do ônus econômico da prova, ${ }^{274}$ de modo que o consumidor continuaria

274 Em defesa dessa tese é comum a referência a precedentes do Superior Tribunal de Justiça, que sustentam que, "acerca da inversão dos ônus da prova e das despesas para custeá-la quando verificada a relação de consumo, prevalece, no âmbito da Segunda Seção desta Corte Superior de Justiça que os efeitos da inversão do ônus da prova não possui a força de 'obrigar a parte contrária a arcar com as custas da prova requerida pelo consumidor' (cf. REsp 816.524/MG, rel. Min. Cesar Asfor Rocha, DJ 08.11.2006)" (REsp 845.601/SP, 4. a T., rel. Min. Hélio Quaglia Barbosa, DJ 02.04.2007). Contudo, em nosso entendimento, a jurisprudência apenas está a ressalvar a não obrigatoriedade da antecipação, por se tratar de um ônus, e, como tal, será sempre uma faculdade do fornecedor. A corroborar nosso posicionamento, o próprio Superior Tribunal de Justiça adverte que "a inversão do ônus da prova não tem o efeito de obrigar a parte contrária a arcar com as custas da prova requerida pelo consumidor. No entanto, sofre as consequências processuais advindas de sua não produção" (STJ, REsp 443.208/RJ, 3. ${ }^{a}$ T., rel. Min. Nancy Andrighi, DJ 17.03.2003). "A regra probatória, quando a demanda versa sobre relação de consumo, é a da inversão do respectivo ônus. Daí não se segue que o réu esteja obrigado a antecipar os honorários do perito; efetivamente não está, mas, se não o fizer, presumir-se-ão verdadeiros os fatos afirmados pelo autor" (STJ, REsp 466.604/RJ, 3. ${ }^{a}$ T., rel. Min. Ari Pargendler, DJ 02.06.2003). Ou seja, o Superior Tribunal de Justiça confirma, em nosso sentir, que o fornecedor 
onerado pela antecipação dos respectivos custos da prova requerida quando ainda estava onerado, ainda que o fornecedor também a requeira para se desincumbir do ônus assumido.

Em sentido contrário, parte da doutrina defende que, se o juiz se valer da redistribuição do ônus da prova, imputando o ônus da prova ao fornecedor, também incumbirá a este a antecipação das despesas inerentes à prova que vier a ser produzida a seu pedido. ${ }^{275}$

Para a correta tomada de posição, contudo, é preciso que analisemos cada situação com mais profundidade e sempre à luz das regras insculpidas nos artigos 19

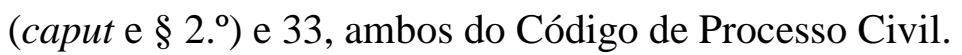

Determina o artigo 19 a regra geral de que, "salvo as disposições concernentes à justiça gratuita, cabe às partes prover as despesas dos atos que realizam ou requerem no processo, antecipando-lhes o pagamento desde o início até sentença final [...]”.

O $§ 2 .^{\circ}$ do referido artigo 19 atribui "ao autor adiantar as despesas relativas a atos, cuja realização o juiz determinar de ofício ou a requerimento do Ministério Público”.

Já o artigo 33, ao tratar especificamente da perícia, prova que pode exigir o maior dispêndio de recursos financeiros, determina que a remuneração "do perito será paga pela parte que houver requerido o exame, ou pelo autor, quando requerido por ambas as partes ou determinado de ofício pelo juiz".

Da leitura dos aludidos textos legais é possível vislumbrar três situações, quais sejam:

assume o ônus financeiro da prova, imputando-lhe os efeitos negativos em caso de não desincumbência.

275 Para ADA PELLEGRINI GRINOVER, "invertido o ônus da prova, pode acontecer que a prova, que era do interesse do autor, passe a ser do interesse do demandado; e, sendo assim, o demandado, a quem interessa provar, adiantará espontaneamente as despesas. Desse modo, a inversão do ônus da prova poderá repercutir na assunção da responsabilidade por seu custeio" (Código..., cit., v. 2, p. 15). No mesmo sentido, EDUARDO CAMBI sustenta que, "quando se inverte o ônus da prova, transferem-se ao fornecedor todos os riscos, custos e responsabilidades quanto à atividade probatória. $\mathrm{O}$ entendimento contrário, ao perpetuar a dificuldade econômica, não facilita a defesa dos direitos do consumidor em juízo, mantendo o status quo anterior" (Divergência jurisprudencial: inversão do ônus da prova e o ônus de antecipar o pagamento dos honorários periciais. Revista dos Tribunais, São Paulo: RT, n. 804, p. 137, out. 2002). 
a) Se a prova foi requerida apenas por uma das partes, cabe a esta antecipar as despesas;

b) Se ambas as partes requereram a prova, as despesas devem ser adiadas pelo "autor"; ou

c) Se a prova foi requerida pelo juiz ou pelo Ministério Público, o "autor" deve custear a prova.

A terminologia empregada nos referidos artigos, contudo, nos parece equivocada e capaz de gerar distorções na incumbência de custeio da prova, sobretudo nas hipóteses das alíneas "b" e "c", supra. Não se nos afigura adequado o uso do termo "autor" na hipótese, pois, a nosso ver, o ônus econômico deve sempre ser atribuído à parte que tem o ônus de provar a questão fática, que pode ser o autor ou o réu. ${ }^{276}$

Com efeito, imaginemos que o réu tenha alegado um fato extintivo do direito do autor e requerido prová-lo por meio de perícia. Em réplica, o autor refuta a alegação do fato extintivo e também pede a produção de perícia para demonstrar que este não ocorreu. O ônus da prova do fato extintivo é do réu, a teor do disposto no inciso II do artigo 333 do Código de Processo Civil. Se ambas as partes requereram a prova, pela regra do artigo 33 do citado diploma legal o ônus econômico da prova seria do autor, o que não nos parece fazer o menor sentido, pois inexiste o real interesse do autor em custear essa prova, sobretudo porque a situação de dúvida lhe beneficia (desde que tenha demonstrado os fatos construtivos do seu direito). O verdadeiro interessado em que essa prova se realize é o réu, a quem o seu resultado aproveita e a quem a frustração da prova prejudica.

Portanto, para a correta interpretação das normas insculpidas no $§ 2 .^{\circ}$ do artigo 19 e na parte final do artigo 33, quando se referem ao "autor", em verdade deve ser

276 A antecipação das respectivas despesas processuais também constitui um ônus para as partes, de modo que somente a parte interessada pode sofrer os efeitos negativos da recusa em antecipar tais verbas. Como sustenta DinAMARCO, "a manifesta legitimidade dessa exigência apoia-se na premissa do interesse, sendo natural atribuir tais ônus ao sujeito que pretende beneficiar-se do ato; interesse, em direito, é utilidade, devendo cada qual custear os atos que possam ser-lhe úteis. [...] Caracterizados assim todos os encargos de preparar como autênticos ônus, entende-se que cada um deles é atribuído sob a sanção de ineficácia do ato realizado pela parte ou de não realização do ato que ela requereu porque do contrário não seriam verdadeiros ônus" (Instituições..., cit., v. 2, p. 639-640; grifos do autor). Ainda segundo o professor paulista, a transferência dos encargos financeiros ao autor da demanda ensejaria uma inconstitucionalidade da norma, por ofensa à ampla defesa, pois "essa transferência de ônus consiste em atribuí-lo precisamente ao sujeito cujo interesse pode até ficar prejudicado pelo ato a realizar" (Op. cit., p. 646). 
compreendido como "parte interessada no resultado da prova", para que seja mantida a coerência do sistema quanto aos ônus processuais, em especial o ônus probatório e a regra geral do caput do mencionado artigo 19, que atribui à parte interessada o ônus de adiantar as despesas processuais das provas que pretendem produzir para comprovar as suas respectivas alegações de fato.

Voltando à hipótese de redistribuição do ônus da prova, verificamos que ocorre um deslocamento do ônus do consumidor para o fornecedor, o qual fica incumbido de provar alegações de fato que formulou contra as alegações de fato do consumidor e que tornaram o ponto controvertido em questão.

O fornecedor, ao receber o ônus de provar suas alegações, tem o interesse em se desincumbir de tal ônus e, para tanto, deverá requerer a produção das provas capazes de formar o convencimento do juiz de acordo com a tese sustentada. Ao assim agir, o fornecedor incide na regra geral do artigo 19 do Código de Processo Civil, de sorte que caberá também ao fornecedor o ônus econômico da prova.

Portanto, quando ocorre a redistribuição do ônus da prova, de igual modo se dá a modificação do ônus econômico da prova, conforme o interesse da parte em produzir prova de suas alegações de fato.

Essa conclusão não se alteraria mesmo se antes da redistribuição do ônus da prova o consumidor já houvesse requerido a produção da prova de sua respectiva alegação de fato, porque, como sustentamos anteriormente, mesmo na hipótese em que ambas as partes requerem a prova, o ônus econômico da produção dessa prova deverá ser da "parte interessada" no resultado da prova, que equivale à parte com o ônus de produzi-la, no caso, o fornecedor.

Portanto, entendemos que, sempre que ocorrer a redistribuição do ônus da prova em favor do consumidor, o fornecedor, além de ficar incumbido da produção da prova, também terá o ônus de antecipar as despesas necessárias à produção da prova que pretender realizar para demonstração da veracidade das alegações de fato que embasam a sua pretensão contra o consumidor, ainda que este também tenha requerido a produção dessa prova quando ainda estava onerado. 


\title{
CAPÍTULO 5 \\ DISTRIBUIÇÃO DINÂMICA DO ÔNUS DA PROVA
}

\author{
Nos capítulos anteriores, em especial nos Capítulos 3 e 4, procuramos expor os
}

modelos atualmente vigentes em nosso sistema processual sobre as regras de distribuição do ônus da prova e suas imperfeições, e o mecanismo já existente de "flexibilização" da regra rígida, abstrata e predeterminada do artigo 333 do Código de Processo Civil quanto estiver em debate uma relação de consumo.

A partir desse momento, adentraremos na exposição de uma técnica diferenciada de fixação dos ônus probatórios, denominada "distribuição dinâmica dos ônus probatórios", ${ }^{277}$ que ainda não encontra amparo legislativo expresso no direito brasileiro, ${ }^{278}$ mas que já é uma realidade na prática judiciária, e que cada vez mais vem ganhando adeptos na doutrina. ${ }^{279}$

277 Essa técnica recebe ainda outras denominações na doutrina, como carga dinâmica da prova, carga de prova compartilhada e cargas probatórias dinâmicas, adotando-se o termo "carga" do espanhol como sinônimo de "ônus". Entretanto, em nosso sentir, o elemento dinâmico está relacionado à distribuição do ônus, e não ao ônus em si, daí por que entendemos ser incorreto se referir à técnica como "ônus dinâmico da prova".

278 O Código projetado (Substitutivo da Câmara dos Deputados ao Projeto de Lei n. ${ }^{\circ}$ 166/2010 do Senado Federal) traz previsão sobre o tema. Contudo, antes mesmo de sua conversão em lei, sustentamos a aplicabilidade da técnica de distribuição dinâmica do ônus da prova a partir de uma interpretação sistemática do Código de Processo Civil e da Constituição Federal, tema que será mais bem abordado no item "5.6", adiante.

279 Especificamente no direito pátrio, podemos citar as seguintes obras: DALL'AGNOL JUNIOR, Antonio Janyr. Distribuição dinâmica dos ônus probatórios. Revista dos Tribunais, São Paulo: RT, n. 788, jun. 2001. DELL'ISOLA, Carmela. O ônus..., cit.. LOPES, João Batista. A prova..., cit.. AZÁRIO, Márcia Pereira. Dinamicização da distribuição do ônus da prova no processo civil brasileiro. 2006. Dissertação (Mestrado em Direito) - Universidade Federal do Rio Grande do Sul UFRGS, Porto Alegre. MARINONI, Luiz Guilherme. Formação da convicção e inversão do ônus da prova segundo as peculiaridades do caso concreto. Revista dos Tribunais, São Paulo: RT, v. 96, n. 862, ago. 2007. GODINHO, Robson Renault. A distribuição do ônus da prova na perspectiva dos direitos fundamentais. Revista da Ajuris, Porto Alegre, v. 35, n. 109, mar. 2008. AZEVEDO, Antonio Danilo Moura de. A aplicabilidade da teoria dinâmica de distribuição do ônus da prova no processo civil. Revista Jurídica Unijus, Uberaba: Universidade de Uberaba, v. 11, n. 14, maio 2008. ZANFERDINI, Flávia de Almeida Montingelli; GOMES, Alexandre Gir. Cargas probatórias dinâmicas no processo civil brasileiro. Revista Dialética de Direito Processual, São Paulo, n. 69, dezembro, 2008. CREMASCO, Suzana Santi. A distribuição dinâmica do ônus da prova. Rio de Janeiro: GZ, 2009. GIORGIS, José Carlos Teixeira. A prova dinâmica no direito de família. In: MILHORANZA, Mariângela Guerreiro (Coord.); PEREIRA, Sérgio Gischkow (Coord.). Direito contemporâneo de família e das sucessões: estudos jurídicos em homenagem aos 20 anos de docência do Prof. Rolf Madaleno. Rio de Janeiro: GZ, 2009. NOGUEIRA, Pedro Henrique Pedrosa. A inversão do ônus da prova no Código de Defesa do Consumidor como técnica de distribuição dinâmica da carga probatória. Revista Dialética de Direito Processual, São Paulo: Dialética, n. 75, jun. 2009. PELEJA JÚNIOR, Antônio Veloso. Ativismo judicial e ônus da prova: a teoria da distribuição dinâmica. Revista Jurídica do Ministério Público de Mato Grosso, Cuiabá: Entrelinhas, v. 4, n. 6, 
Por se tratar de tema ainda embrionário entre nós e para mantermos o rigor científico que se exige no desenvolvimento de qualquer estudo, vamos dividir a exposição sobre a técnica em oito tópicos, dos quais os quatro iniciais estarão focados na exposição teórico-dogmática, a partir: (i) da análise dos pressupostos axiológicos que fundamentam a técnica; (ii) das suas características essenciais; (iii) dos seus requisitos condicionantes de aplicabilidade, tanto intrínsecos (ou materiais) como extrínsecos (ou processuais); e (iv) do momento e limites da sua aplicação, ${ }^{280}$ com o que procuraremos estabelecer uma definição

jan.-jun. 2009. CARPES, Artur Thompsen. Ônus dinâmico..., cit.. HIGINO NETO, Vicente. Ônus da prova: teorias da redução do módulo da prova e das provas dinâmicas e compartilhadas. Curitiba: Juruá, 2010. PACÍFICO, Luiz Eduardo Boaventura. O ônus..., cit.. REDONDO, Bruno Garcia. Ônus da prova e distribuição dinâmica: lineamentos atuais. In: MOREIRA, Alberto Camiña (Coord.); ALVAREZ, Anselmo Prieto (Coord.); BRUSCHI, Gilberto Gomes (Coord.). Panorama atual das tutelas individual e coletiva: estudos em homenagem ao professor Sérgio Shimura. São Paulo: Saraiva, 2011. ZANETI, Paulo Rogério. Flexibilização das regras sobre o ônus da prova. São Paulo, SP: Malheiros, 2011. LAZARI, Rafael José Nadim de; SOUZA, Gelson Amaro de. Reflexões sobre a perspectiva de uma distribuição dinâmica do ônus da prova: análise da viabilidade. Revista Dialética de Direito Processual, São Paulo: Dialética, n. 99, jun. 2011. CARDOSO, Oscar Valente. Peculiaridades da inversão do ônus da prova no CDC: teoria dinâmica, hipossuficiência e extratos bancários. Revista Dialética de Direito Processual, São Paulo: Dialética, n. 102, set. 2011. COUTO, Camilo José D’ávila. Dinamização do ônus da prova: teoria e prática. 2011. Tese (Doutorado em Direito) - Faculdade de Direito, Universidade de São Paulo, São Paulo. YOSHIKAWA, Eduardo Henrique de Oliveira. Considerações sobre a teoria da distribuição dinâmica do ônus da prova. Revista de Processo, São Paulo: RT, v. 37, n. 205, mar. 2012. LOPES, João Batista. Ônus da prova e teoria das cargas dinâmicas no novo Código de Processo Civil. Revista de Processo, São Paulo: RT, v. 37, n. 204, fev. 2012. BAZZANEZE, Thaís. Distribuição dinâmica dos ônus probatórios: análise à luz do devido processo legal e do acesso à justiça. Revista de Processo, São Paulo: RT, v. 37, n. 205, mar. 2012. RIBEIRO, Flávia Pereira. A regulamentação da teoria da carga dinâmica das provas. In: SILVA, Jose Anchieta da (Org.). O novo processo civil. São Paulo: Lex, 2012. MACHADO, Marcelo Pacheco. Ônus estático, ônus dinâmico e inversão do ônus da prova: análise crítica do Projeto de novo Código de Processo Civil. Revista de Processo, São Paulo: RT, v. 37, n. 208, jun. 2012. GARCIA, André Almeida. A distribuição do ônus da prova e sua inversão judicial no sistema processual vigente e no projetado. Revista de Processo, São Paulo: RT, v. 37, n. 208, jun. 2012. SANTOS, José Carlos Van Cleef de Almeida. O ônus da prova e a teoria da carga dinâmica. Revista dos Tribunais, São Paulo: RT, v. 101, n. 924, out. 2012. LUCON, Paulo Henrique dos Santos; COSTA, Guilherme Recena. Formalismo processual e dinamização do ônus da prova. In: MITIDIERO, Daniel; AMARAL, Guilherme Rizzo (Coord.); FEIJÓ, Maria Angélica Echer Ferreira (Org.). Processo civil: estudos em homenagem ao professor doutor Carlos Alberto Alvaro de Oliveira. São Paulo: Atlas, 2012. FERMANN, Rodrigo Papaléo. Teoria da distribuição dinâmica do ônus da prova. In: MITIDIERO, Daniel (Org.). O processo civil no estado constitucional. Salvador: Juspodivm, 2012. SILVEIRA, Bruna Braga da. Notas sobre a teoria dinâmica do ônus da prova. Revista de Direito Privado, São Paulo, v. 13, n. 52, p. 263-82. out.-dez. 2012. MORAES, Denise Maria Rodríguez. A dinamização da regra de distribuição do ônus da prova como instrumento de busca da verdade e de efetivação da justiça. Revista de Processo. São Paulo: RT, v. 38, n. 226, dez. 2013. MACÊDO, Lucas Buril de.; PEIXOTO, Ravi Medeiros. Ônus..., cit.. LIMA, Cíntia Rosa Pereira de; FANECO, Lívia Carvalho da Silva. Inversão do ônus da prova no CDC e a inversão procedimental no projeto de novo CPC: distinção entre institutos afins. Revista de Direito do Consumidor, São Paulo: RT, v. 23, n. 91, jan. 2014. OLIVEIRA, Vivian von Hertwig Fernandes de. A distribuição do ônus da prova no processo civil brasileiro: a teoria da distribuição dinâmica. Revista de Processo, São Paulo: RT, v. 39, n. 231, mai. 2014. BARBOSA, Rafael Vinheiro Monteiro. O ônus da prova no direito processual civil e a sua inversão - a visão do STJ. Revista de Processo, São Paulo: RT, v. 39, n. 233, jul. 2014.

280 Nesse ponto talvez esteja a principal divergência que teremos em relação à técnica sustentada na Argentina e no qual faremos a aproximação da técnica de dinamização com a técnica de redistribuição prevista para as ações envolvendo relações de consumo no direito pátrio. 
para a regra de aplicabilidade, ${ }^{281}$ os quais se fazem necessários para evitar arbitrariedades de, no afã de dar vida à novidade, desvirtuá-la por completo.

Em seguida, procuraremos estabelecer um paralelo entre a técnica dinâmica e a redistribuição do ônus da prova prevista para as relações de consumo no direito pátrio, que, como já antecipados, entendemos terem uma matriz idêntica, embora sob diferentes enfoques.

A par da ausência de norma expressa, de lege ferenda, exporemos os motivos que, em nosso entendimento, permitem sustentar a aplicabilidade da técnica da distribuição dinâmica dos ônus da prova à luz do direito vigente, com base em uma interpretação sistemática das normas, garantias e princípios processuais e constitucionais.

Fixadas as bases teóricas dessa técnica processual, analisaremos no tópico seguinte as delimitações projetadas pelo legislador pátrio para introdução dessa técnica no direito vigente, a partir da redação sugerida para o artigo 370 do Projeto de Lei n. ${ }^{\circ}$ 166/2010 do Senado Federal, que tramita no Congresso para aprovação de um novo Código de Processo Civil. ${ }^{282}$

\subsection{Pressupostos axiológicos da técnica de distribuição dinâmica do ônus da prova}

A definição de um novo modelo de distribuição dos ônus probatórios surge a partir da evolução do conceito de processo, que deixa de ser uma mera disputa entre

281 Ainda que com a evolução e aprofundamento do conhecimento o estabelecimento de conceitos e definições possa se tornar algo obsoleto, entendemos sejam relevantes para a fixação de ideias e explicação de certos fenômenos em um determinado momento histórico. Como lembra STEPHEN DOWNES, professor da Universidade de Alberta, Canadá, em seu Guide to the logical fallacies, "in order to make our words or concepts clear, we use a definition. The purpose of a definition is to state exactly what a word means. A good definition should enable a reader to 'pick out' instances of the word or concept with no outside help" (Disponível em: <http://www.onegoodmove.org/fallacy/ define_index.htm>. Acesso em: 22 nov. 2014).

282 Não ignoramos a existência de outras tentativas, no passado, de introdução da teoria da distribuição dinâmica dos ônus probatórios no sistema legislativo brasileiro, como o Anteprojeto de Código Brasileiro de Processos Coletivos e o Projeto de Lei n. ${ }^{\circ}$ 3015/2008, mas em face do arquivamento do primeiro e a prejudicialidade do segundo diante da possibilidade de termos um "novo" Código de Processo Civil caso o Projeto de Lei n. ${ }^{\circ}$ 166/2010 do Senado Federal seja aprovado e convertido em lei, concentraremos nossos estudos na exposição crítica do texto do referido projeto. 
particulares para se transformar em um mecanismo social de pacificação, calcado no ideal de máxima asseguração da tutela jurisdicional. No presente item procuraremos expor os princípios que norteiam essa nova visão do processo e que, consequentemente, embasam o emprego da técnica dinâmica como mecanismo de potencialização da descoberta dos fatos e obtenção da tutela jurisdicional justa.

\subsubsection{Processo civil constitucional}

A partir de meados do século passado, o processo civil sofreu profundas modificações da forma como era encarado pelas partes e pelo Estado-juiz, relativizando-se o princípio dispositivo em matéria probatória em prol de um processo comprometido com a descoberta da verdade e a concessão da tutela jurisdicional efetiva. Nessa esteira, ganharam relevância os mecanismos probatórios disponibilizados às partes e os poderes instrutórios do juiz.

O fenômeno de remodelação do processo à luz dos preceitos constitucionais e dos direitos fundamentais recebeu o nome de "constitucionalização" do processo, que pode ser interpretado em duplo sentido: o primeiro, correspondente à ampliação dos mecanismos de controle da constitucionalidade dos atos estatais, por meio de ações como a Ação Direta de Inconstitucionalidade ou Constitucionalidade, a Arguição de Descumprimento de Preceito Fundamental ou mesmo a Ação Popular, entre outras, e o segundo (que é o interessa ao presente trabalho), consistente na incorporação de princípios e garantias processuais no texto constitucional, passando o processo e a concessão da tutela jurisdicional a serem vistos não mais apenas por seus aspectos formais ou de estrita legalidade, mas como o verdadeiro epicentro das preocupações dos estudiosos e operadores do Direito. ${ }^{283}$

283 Para JOÃO BATISTA LOPES, a constitucionalização do processo é "um método de trabalho, uma nova postura do processualista: estudar o processo civil com olhos voltados para a Constituição. [...] Não se trata, pois, de esvaziar o direito processual civil, mas de estudá-lo à luz da Constituição para fazer atuar concretamente os valores da ordem jurídica" (Efetividade da tutela jurisdicional à luz da constitucionalização do processo civil. Revista de Processo, São Paulo: RT, n. 116, p. 30, jul. 2004). Para COMOGLIO, FERRI e TARUFFO, a garantia constitucional do processo "deriva da uno degli aspetti più relevanti del c.d.constituzionalismo moderno, rappresentato all'introduzione, nel sistema dei principi constituzionali, di garanzie attinenti al processo. [...] Anzitutto, esso constituisce en esito della tendenza a considerare tale disciplinanon solo come un insieme di norme destinate a regolare un metodo per la soluzione dei conflitti, ma anche come un 'luogo' di valori autonomi, attinenti alla 
Nessa perspectiva, a jurisdição deixa de ser observada apenas pelo seu aspecto jurídico, ganhando igual relevância os escopos social e político, que se concretizam na medida em que a justiça da decisão é gradativa e constantemente alcançada, por um processo équo e justo, dos pontos de vista formal e material. ${ }^{284}$

Com efeito, a finalidade do processo é a realização da justiça concreta, e, quando desenvolvido de maneira escorreita, ou seja, com base nos princípios constitucionalmente consagrados e nos valores partilhados pela coletividade, perante um juiz imparcial, em contraditório e em tempo razoável, permite que o litígio seja resolvido de forma efetiva e justa.

A fase instrumentalista do processo, amplamente disseminada por DINAMARCO desde os anos $80,{ }^{285}$ parece atender perfeitamente aos anseios do modelo constitucional do processo focado em um juiz ativo, preocupado com a sua efetividade e a observância das garantias constitucionais, embora ainda enraizado em um legalismo ${ }^{286}$ que por vezes acaba

strutura del proceso e destinati ad essere atuati in quanto tali" (Lezioni sul processo civile: Il processo ordinario di cognizione. Bolonha: Il Mulino, 2006. t. I, v. 2, p. 20-21).

284 Comoglio, dissertando sobre a justiça substancial assevera que "quest'ultima impone di considerare come dovuto (e cioè: come due, debido o devido) non già qualunque processo che si limiti ad essere estrinsecamente fair (vale a dire: corretto, leale o regolare, sul piano formale, secondo la law of the land), bensi un processo che sia intrinsecamente equo e giusto, secondo i parametri etico-morali accettati dal comune sentimento degli uomini liberi di qualsiasi epoca e paese, in quanto si riveli capace di realizzare una giustizia veramente imparziale, fondata sulla natura e sulla ragione. Da qui traggono origine le postulazioni teoriche, ormai quasi dovunque condivise, per la promulgazione e l'adozione di solenni atti legislativi (nazionali od internazionali) che riconoscano a tutti, in termini effettivi e senza irrazionali discriminazioni, il diritto fondamentale ad un processo equo e giusto, quale nucleo essenziale del più ampio diritto ad un ordinamento giuridico giusto" [Garanzie costituzionali e "giusto processo" (modelli a confronto). Revista de Processo, São Paulo: RT, n. 90, p. 98, abr. 1998]. A partir da obra A instrumentalidade do processo, cuja primeira edição é de 1987.

Segundo o pensamento instrumentalista, a jurisdição tem a função de declarar o direito conforme a “concreta vontade da lei”, de acordo com expressão cunhada por CHIOVENDA (Instituições..., cit., v. 2, p. 3), o que, no entendimento de PONTES DE MIRANDA, carece de sentido, pois esse voluntarismo é algo que remonta a "tempos despóticos" e que tendem a desaparecer. "O processo serve à aplicação da lei que incidiu, sem que o obrigado cumprisse a sua obrigação, ou para aquela realização de direito objetivo sem sujeito particular da obrigação, o que se verifica em muitos casos de sentença constitutiva. Num e noutro caso, é o Estado que se incumbe disso, e reconhece aos sujeitos o direito de lhe pedir que 'concretize' a regra abstrata" (Comentários ao Código de Processo Civil. 4. ed. Rio de Janeiro: Forense, 1995. t. 1, p. 23; grifos do autor). No mesmo sentido é o posicionamento de PIERO CALAMANDREI, que leciona que "il giudice è chiamato a fare opera non di volontà, ma di intelletto; deve limitarsi ad apprendere, e a riprodurre fedelmente nella sua sentenza, la volontà della legge già individuata e concreta fuori di lui; deve insomma essere lo storico di una volontà altrui, che preesiste alla sua dichiarazione e che egli deve considerare come un evento già accaduto nella realtà" (Il giudice e lo storico. Studi sul processo civile. Padova: Cedam, 1947. v. 5, p. 41). Daí por que seja mais adequado afirmar que o processo tem por finalidade a "atuação" concreta do direito material, porquanto desprovidos este ou aquele de qualquer "vontade". 
por abalar os seus pilares, quais sejam os valores da justiça, igualdade, participação, efetividade e segurança.

Como evolução ${ }^{287}$ dessa fase instrumental, ALVARO DE OLIVEIRA propõe o exame do processo a partir de um modelo que denominou "formalismo-valorativo", o qual enxerga o processo como um fenômeno cultural, pois é produto do homem, e, como tal, carrega em seu âmago os valores de determinada sociedade, conforme seu tempo e local. ${ }^{288}$

Ainda segundo o autor gaúcho, a sociedade contemporânea está preocupada e concentrada com a efetividade da tutela jurisdicional, nem que, para isso, em determinados momentos, seja necessário o abandono do tecnicismo, porém nunca sem perder de foco o "sobreprincípio" da segurança, que faz o exato contrapeso para limar do sistema qualquer resquício de arbitrariedade e, consequentemente, injustiça.

Para aquilo que nos interessa neste trabalho, o papel do juiz na instrução probatória e a distribuição do ônus da prova, as principais contribuições dessa nova roupagem do processo são quatro, quais sejam: a sobressalência da igualdade material à formal, a adaptabilidade do procedimento, o ativismo judicial associado à melhor cognição dos fatos e a visão participativa e colaborativa do processo.

Nesse sistema processual regido pelo "formalismo-valorativo", a igualdade formal somente tem espaço como mecanismo impeditivo de normas discriminatórias ou protetivas de apenas uma parcela do grupo social em detrimento dos demais. Para o processo, em especial para a reconstrução dos fatos que embasam as teses e pretensões conflituosas das partes, não se podem mais ignorar as diferenças sociais, culturais e econômicas naturalmente existentes entre os indivíduos, que, como vimos no item " 3.2 " do Capítulo 3, afetam diretamente as suas respectivas capacidades probatórias.

Essa desigualdade substancial entre os indivíduos deve ser levada em consideração pelo juiz no momento de definir os pontos controvertidos da demanda, sobre os quais recairão os ônus probatórios das partes, atribuindo os respectivos ônus como

287 O termo parece o mais adequado porque a nova linha de pensamento não configura uma ruptura do modelo precedente, mas a necessidade de pensar um pouco além, buscando a satisfação do direito material à luz das nuances do caso concreto. 
forma de "nivelar" ou "renivelar" as forças das partes, de modo que ambas possam exercer o contraditório de forma plena e equânime e, assim, tenham o poder influenciar no julgamento do conflito em igualdade de condições. ${ }^{289}$

Como decorrência desses "ajustes" a serem realizados pelo juiz no curso do processo para assegurar às partes a igualdade substancial, o formalismo-valorativo também sustenta uma adaptabilidade do procedimento, que pode ser desde uma inversão na ordem de colheita das provas, até o abandono da regra geral e abstrata de distribuição do ônus da prova, sempre com o objetivo de realização do direito material à luz do caso concreto.

A forma tem sentido quando em consonância com uma finalidade. A técnica processual deve seguir um formalismo apenas como medida de previsibilidade ao procedimento, mas para a realização das particularidades do direito material em discussão deve-se admitir a sua flexibilização. ${ }^{290}$

Outro ponto de vital relevância para o desenvolvimento da instrução e do posterior julgamento da causa no modelo do formalismo-valorativo é a atuação ativa do juiz na reconstrução dos fatos, que se dá, inicialmente, com o estabelecimento de um contato mais direto do juiz com as partes e do juiz com as provas, ampliando-se o diálogo para que a cognição dos fatos controvertidos seja tanto quanto possível a mais ampla e esclarecedora à percepção do juiz, de modo que possa proferir uma decisão mais justa. ${ }^{291}$

Ainda que o juiz tenha poderes de determinar a produção de provas mesmo de ofício, com maiores ou menores restrições conforme a corrente doutrinária a que se filie,

289 Dessa forma, será possível que o contraditório exerça sua dupla função: garantir a igualdade entre as partes e satisfazer o interesse público na descoberta da verdade e realização da justiça (OLIVEIRA, Carlos Alberto Alvaro de. Do formalismo..., cit., p. 159).

290 Para FERNANDO DA FONSECA GAJARDONI, "modernamente, a cláusula do devido processo compreende o direito constitucional a um procedimento adequado, isto é, conduzido sob o pálio do contraditório, aderente à realidade social e consentâneo com a relação de direito material controvertida. Exatamente por isso a adequação do procedimento abstratamente e rigidamente previsto em lei às peculiaridades ligadas ao direito material, caso a caso, acaba por favorecer o princípio do devido processo legal ao invés de esmorecê-lo" (Flexibilização procedimental: um enfoque para o estudo do procedimento em matéria processual, de acordo com as recentes reformas do CPC. São Paulo: Atlas, 2008. p. 100).

291 Retomamos aqui as ideias desenvolvidas no Capítulo 1 desta dissertação, associando a justiça da decisão à precisão com que os fatos foram apurados e provados, sendo inconteste que o processo será tanto mais justo quanto melhor for a instrução probatória e a formação do juízo de certeza no momento de julgar, definido por TARUFFO como "critério de eficiência" (Uma simples verdade..., cit., p. 235-236). 
em determinadas situações, somente as partes é que poderão efetivamente contribuir para o esclarecimento das questões fáticas ainda pendentes de prova.

Nessas circunstâncias, desde que presentes os demais requisitos a serem devidamente examinados a seguir, para que o juiz tenha pleno acesso à prova de tais fatos, a regra de distribuição do ônus probatório em abstrato pode não ser suficiente, a exigir sua modificação, de forma que o ônus da prova atenda adequadamente à sua função epistêmica, mediante a imposição de uma situação de desvantagem para a parte com maior capacidade de produzir prova para que se sinta pressionada a fazer a prova da veracidade/não veracidade da alegação controvertida. ${ }^{292}$

Com a adoção de tal tipo de medida, o juiz promove uma condução do processo direcionada à solução do conflito e à pacificação, mediante o emprego de meios idôneos que asseguram a efetividade da tutela, ao menos do ponto de vista da qualidade, pois, por outro lado, ao assim agir, pode ocorrer um incremento de tempo e de custos, que, em nossa opinião, compensam se forem em favorecimento da justiça da decisão.

Afinal, se o processo moroso e injusto é abominável, um processo rápido e igualmente injusto também é indesejável. ${ }^{293}$ Cabe ao magistrado, com o diálogo estabelecido com as partes, extrair a dosimetria adequada a cada caso concreto para equilibrar segurança e efetividade para dar uma tutela justa e adequada à parte reconhecidamente titular do direito material litigioso.

Nessa avaliação individualizada do caso concreto, a participação das partes se torna fundamental para afirmar o caráter democrático do Estado e, essencialmente, para assegurar possibilidades iguais de influenciar no convencimento do juiz e no seu julgamento sobre o objeto da demanda (conceito moderno de contraditório). ${ }^{294}$

292 Nesse sentido, confira-se TARUFFO, a regra sobre distribuição do ônus da prova "orienta-se no sentido de favorecer a apuração da verdade e de fazer com que a decisão final funde-se em tal apuração. Essa coloca par a parte que alega um fato a pressão de fornecer a prova, ameaçando-a - por assim dizer de derrota caso o fato não resulte provado" (Uma simples verdade..., cit., p. 260).

293 "Se uma justiça lenta demais é decerto uma justiça má, daí não se segue que uma justiça muito rápida seja necessariamente uma justiça boa. $\mathrm{O}$ que todos devemos querer é que a prestação jurisdicional venha a ser melhor do que é. Se para torná-la melhor é preciso acelerá-la, muito bem: não, contudo, a qualquer preço". (BARBOSA MOREIRA, José Carlos. O futuro da justiça: alguns mitos. Revista de Processo, São Paulo: RT, v. 26, n. 102, p. 230, abr. 2001).

294 Como define CANOTILHO, democracia participativa compreende "[...] a estruturação de processos que ofereçam aos cidadãos efetivas possibilidades de aprender a democracia, participar nos processos de 
Trata-se, enfim, de uma visão "social" do processo, em que o processo não é visto como um mero campo de batalhas, em que as partes têm "paridade de armas", mas como um ambiente em que a civilidade e a probidade devem prevalecer ainda que a conflituosidade seja fumegante.

O juiz, com o papel atuante na condução do processo e, principalmente, na instrução probatória, irá intervir supletivamente para suprir eventuais deficiências técnicas e/ou econômicas das partes, podendo exigir da outra parte a satisfação de um dever ou um ônus que não lhe cabia originalmente, haja vista que essa parte pode se desincumbir de determinada tarefa ou prova com o dispêndio de menos esforços que o seu adversário.

Como decorrência, é exigido das partes um dever de colaboração e cooperação para o regular desenvolvimento do processo e a correta instrução probatória. Afinal, o interesse das partes é ter razão e elas agem como partes interessadas; o processo, por seu turno, tem como finalidade dar razão a quem efetivamente a tem, ${ }^{295}$ daí por que ser razoável exigir das partes que demonstrem quem efetivamente tem razão.

No tópico seguinte discorreremos mais detidamente sobre o dever de colaboração e sua relevância na técnica de distribuição dinâmica do ônus probatório.

\subsubsection{Dever processual de colaboração na obtenção da prova}

Outro elemento essencial do processo é o denominado "dever de colaboração", também chamado de "dever de cooperação" na instrução probatória e apuração dos fatos relevantes, ${ }^{296}$ instituído pelo modelo cooperativo de processo, que deve ser pautado pela colaboração do juiz para com as partes e destas para com o juiz. ${ }^{297}$

decisão, exercer controle político nas divergências de opiniões, produzir inputs democráticos" (Direito constitucional e teoria da constituição. 4. ed. Coimbra: Almedina, 2000. p. 286).

295 "Lo scopo di ciascuna dele parti è di aver ragione; la finalità del processo, invece, è di dar ragione a chi l'ha effettivamente" (BETTI, Emilio. Diritto..., cit., p. 5).

296 O estudo da relação entre ônus da prova e dever de colaboração pode ser feito por três ângulos: político, filosófico e prático. Para os objetivos do presente trabalho, em relação ao aspecto político, devemos ter presente que, a partir da constitucionalização do processo, fica superada a visão individualista, e a solução dos conflitos deve se pautar pela igualdade substancial e não meramente formal das partes. Da mesma forma, pelo aspecto filosófico, "deve ser superado o modelo demonstrativo, geométrico e cartesiano da prova no processo civil", substituindo a verdade "formal" 
Do dever genérico de colaboração podemos extrair quatro deveres correlatos, quais sejam: o dever de esclarecimento, o dever de correção, o dever de consulta e o dever de auxílio.

Para a correta instrução probatória, têm relevância os deveres de esclarecimento e de auxílio ${ }^{298}$, por meio dos quais o juiz adotará uma conduta diligente na apuração dos fatos e poderá exigir das partes uma atuação ativa na atividade probatória para que possa ser atingido o resultado justo do processo.

Com efeito, o processo civil moderno tem como premissa o diálogo, e este somente se mostra factível se as partes e o juiz estiverem em um mesmo grau de relevância, ${ }^{299}$ em que a interação se torne possível. O juiz não pode se isolar em seu pedestal e soberba e acreditar que com isso ele conseguirá manter-se "equidistante" e, portanto, "imparcial".

Imparcialidade não se confunde com passividade, sendo um dever do juiz se aproximar das partes, da realidade do caso concreto e dos fatos sobre os quais deverá tomar sua decisão.

ou "real" por uma verdade "processual" (aquela que pode ser obtida no processo). Por fim, do ponto de vista prático-procedimental, deve ser considerado o incremento dos poderes instrutórios do juiz e a relativização do princípio dispositivo, "fazendo crescer a importância da garantia do contraditório real na atividade probatória, com o seu trinômio informação - reação - diálogo" [COITINHO, Jair Pereira. Prova e dever de colaboração: o juízo de fato e a conduta dos sujeitos principais no processo civil brasileiro contemporâneo. 2007. Dissertação (Mestrado em Direito) - Pontifícia Universidade Católica do Rio Grande do Sul, Porto Alegre].

“A colaboração é um modelo que visa a organizar o papel das partes e do juiz na conformação do processo, estruturando-o como uma verdadeira comunidade de trabalho (Arbeitsgemeinschaft), em que se privilegia o trabalho processual em conjunto do juiz e das partes (prozessualen Zusammenarbeit)" (MITIDIERO, Daniel. Processo justo, colaboração e ônus da prova. Revista do Tribunal Superior do Trabalho, Rio de Janeiro, v. 78, n. 1, p. 68, jan.-mar. 2012; grifos do autor). Para um estudo mais aprofundado da matéria, recomendamos outra obra de DANIEL MITIDIERO, com ampla referência bibliográfica, embora o seu enfoque seja apenas o dever de colaboração do juiz para com as partes, e não destas para com aquele (Colaboração no processo civil: pressupostos sociais, lógicos e éticos. 2. ed. São Paulo: RT, 2011).

A Ley de Enjuiciamiento Civil da Espanha, em seu artigo 429.1.II e III, traz norma explícita sobre tais deveres, no seguinte sentido:

“Artículo 429. Proposición y admisión de la prueba. Señalamiento del juicio [...]

Cuando el tribunal considere que las pruebas propuestas por las partes pudieran resultar insuficientes para el esclarecimiento de los hechos controvertidos lo pondrá de manifiesto a las partes indicando el hecho o hechos que, a su juicio, podrían verse afectados por la insuficiencia probatoria [...].

En el caso a que se refiere el párrafo anterior, las partes podrán completar o modificar sus proposiciones de prueba a la vista de lo manifestado por el tribunal". 
Ao assim agir, o magistrado consegue estimular um ambiente de participação das partes, substituindo a oposição e o confronto pelo diálogo e a colaboração dos interessados na reconstrução dos fatos e valorização da causa. ${ }^{300}$

Ainda que não seja um diálogo direto entre as partes, porque a litigiosidade entre ambas lhes é inerente, ao menos mostra-se possível a comunicação das partes para com o juiz e do juiz para com as partes. ${ }^{301}$

O que o juiz deve estimular e impulsionar é a participação ativa das partes, ao mesmo tempo em que ele, juiz, deve direcionar o andamento do processo para o adequado esclarecimento dos fatos controvertidos para melhor decidir.

Essa "divisão de trabalho", como assevera BARBOSA MOREIRA, ${ }^{302}$ é fundamental para a instrução probatória, sobretudo em face da complexidade e multiplicação das relações interpessoais, que se tornam, em verdade, cada vez mais impessoais e de difícil captação pela generalidade das pessoas, sendo as próprias partes, em regra, aquelas que melhor podem disseminar as nuvens de incerteza que naturalmente encobrem a cognição do juiz.

Nesse contexto, é a condução diligente e ativa do processo pelo juiz que permitirá a confirmação do tratamento igualitário entre as partes a que nos referimos no tópico precedente, suprindo pelo diálogo e pela exigência de uma conduta escorreita das partes eventuais desigualdades, e encontrando no processo um ponto de equilíbrio entre as partes.

300 OLIVEIRA, Carlos Alberto Alvaro de. Do formalismo..., cit., p. 191.

301 Como adverte Ravi Medeiros PeiXoto, "é imprescindível que a adoção de um novo modelo de processo venha acompanhado, também, pela mudança cultural dos partícipes da relação processual, que devem se conscientizar da importância da atuação conforme a boa-fé objetiva. Não é que se deseje construir um processo em que todos busquem o mesmo interesse, pois o embate de posições é pressuposto para a utilização do processo judicial, mas a violação da boa-fé objetiva não. É isso que busca o processo cooperativo: uma disputa leal entre interesses opostos, com uma postura dialética do magistrado, que tenta alcançar a decisão mais correta ao caso concreto mediante o diálogo com as partes. É, portanto, um processo que tem, como protagonistas não as partes ou o magistrado, mas todos os sujeitos da relação processual. Não haverá, então, uma cooperação entre as partes, mas entre essas e o magistrado, que deverá conduzir e impedir atitudes que violem a boa-fé objetiva e que violem o ambiente comunicativo do processo" (Rumo à construção de um processo cooperativo. Revista de Processo, São Paulo: RT, n. 219, p. 93, maio 2013). 
Por outro lado, o juiz deve exigir das partes uma conduta colaborativa, ${ }^{303}$ para que não se furtem em contribuir para a descoberta da verdade e a correta valoração dos fatos, imprescindíveis para a concessão da tutela jurisdicional justa e condizente com o direito material.

Essa exigência se faz necessária porque o juiz toma conhecimento dos fatos a partir das alegações formuladas pelas partes interessadas, que visam, acima de tudo, o êxito na medida judicial em curso, de modo que esses fatos nem sempre são expostos de maneira clara e precisa em um primeiro momento, razão pela qual o magistrado precisa invocar o dever de colaboração das partes para obter os esclarecimentos pertinentes de modo que consiga formar o seu convencimento. ${ }^{304}$

O Código de Processo Civil prevê expressamente no artigo 339 o dever de colaboração "para o descobrimento da verdade", 305 e, não obstante a omissão do texto legal quanto ao sujeito passivo desse dever, por certo que se aplica tanto às partes quanto aos terceiros $^{306}$ que possam deter alguma informação relevante para o deslinde da controvérsia.

\section{Como sustentam LuIz GuILHERME MARINONI e SÉRgIO CRUZ ARENHART,}

[...] a ratio essendi dessa previsão é evidente: se o Estado deve solucionar o conflito de interesses com a finalidade de aplicar o direito - sendo esse, também, o objetivo último da sociedade na instituição do Estado-jurisdição -, a coletividade deve ministrar meios (de forma mais completa possível) para que a decisão jurisdicional seja a mais adequada possível. Daí resulta que o dever de colaboração é inerente ao monopólio da jurisdição. Demais disso, não é possível esquecer que esse dever decorre do dever geral de sujeição ao poder do Estado. Afinal, se todos estão submetidos ao poder estatal, igualmente estão subjugados pela jurisdição, de forma a estarem constrangidos a colaborar com o Estado para a descoberta da verdade. ${ }^{307}$

No direito estrangeiro também encontramos diversas referências ao dever de cooperação, com destaque para o Código de Processo Civil de Portugal, que menciona o

303 PONTES DE MiRANDA já falava em um dever de cooperação das partes para com o magistrado, definindo-o como o dever "de colimar rápido e justo desenvolvimento do processo", devendo "obrar de boa-fé e segundo as leis" (Comentários..., t. 1, p. XXII).

Desde os glosadores se pronuncia que o juiz deve julgar secundum allegata et probata e não secundum conscientiam, ou seja, deve se valer dos fatos comprovados, e não da sua "ciência privada", mas essa "restrição" não impede que no processo civil moderno o juiz seja atuante na apuração dos fatos, seja de ofício ou mediante a provocação das partes, inclusive com a distribuição dinâmica do ônus da prova, para que eles possam restar efetivamente provados. Regra que foi repetida, "ipsis litteris", no artigo 375 do projeto do novo Código de Processo Civil. (Considerações..., cit., p. 125). 
"princípio da cooperação" nos artigos $7 .^{\circ}, 8^{\circ}$ e $9 .^{\circ},{ }^{308}$ bem como reforça o "dever de cooperação" no artigo $417 .{ }^{309}$

O projeto do novo Código de Processo Civil, seguindo o modelo português, prevê uma cláusula geral sobre o "princípio da cooperação", definindo no artigo $6 .^{\circ}$ que "todos os sujeitos do processo devem cooperar entre si para que se obtenha, em tempo razoável, decisão de mérito justa e efetiva". 310

308 Artigo $7 .^{\circ}$ Princípio da cooperação

1 - Na condução e intervenção no processo, devem os magistrados, os mandatários judiciais e as próprias partes cooperar entre si, concorrendo para se obter, com brevidade e eficácia, a justa composição do litígio.

2 - O juiz pode, em qualquer altura do processo, ouvir as partes, seus representantes ou mandatários judiciais, convidando-os a fornecer os esclarecimentos sobre a matéria de facto ou de direito que se afigurem pertinentes e dando-se conhecimento à outra parte dos resultados da diligência. 3 - As pessoas referidas no número anterior são obrigadas a comparecer sempre que para isso forem notificadas e a prestar os esclarecimentos que lhes forem pedidos, sem prejuízo do disposto no $n .^{\circ} 3$ do artigo $417 .^{\circ}$.

4 - Sempre que alguma das partes alegue justificadamente dificuldade séria em obter documento ou informação que condicione o eficaz exercício de faculdade ou o cumprimento de ónus ou dever processual, deve o juiz, sempre que possível, providenciar pela remoção do obstáculo.

Artigo $8 .^{\circ}$ Dever de boa-fé processual

As partes devem agir de boa-fé e observar os deveres de cooperação resultantes do preceituado no artigo anterior.

Artigo $90^{\circ}$ Dever de recíproca correção

1 - Todos os intervenientes no processo devem agir em conformidade com um dever de recíproca correção, pautando-se as relações entre advogados e magistrados por um especial dever de urbanidade.

2 - Nenhuma das partes deve usar, nos seus escritos ou alegações orais, expressões desnecessária ou injustificadamente ofensivas da honra ou do bom nome da outra, ou do respeito devido às instituições.

Artigo $417 .^{\circ}$ Dever de cooperação para a descoberta da verdade

1 - Todas as pessoas, sejam ou não partes na causa, têm o dever de prestar a sua colaboração para a descoberta da verdade, respondendo ao que lhes for perguntado, submetendo-se às inspeções necessárias, facultando o que for requisitado e praticando os atos que forem determinados.

2 - Aqueles que recusem a colaboração devida são condenados em multa, sem prejuízo dos meios coercitivos que forem possíveis; se o recusante for parte, o tribunal aprecia livremente o valor da recusa para efeitos probatórios, sem prejuízo da inversão do ónus da prova decorrente do preceituado no n. ${ }^{\circ} 2$ do artigo $344 .^{\circ}$ do Código Civil.

3 - A recusa é, porém, legítima se a obediência importar:

a) Violação da integridade física ou moral das pessoas;

b) Intromissão na vida privada ou familiar, no domicílio, na correspondência ou nas telecomunicações;

c) Violação do sigilo profissional ou de funcionários públicos, ou do segredo de Estado, sem prejuízo do disposto no n. ${ }^{\circ} 4$.

4 - Deduzida escusa com fundamento na alínea c) do número anterior, é aplicável, com as adaptações impostas pela natureza dos interesses em causa, o disposto no processo penal acerca da verificação da legitimidade da escusa e da dispensa do dever de sigilo invocado.

310 MARCELO JOSÉ MAGALHÃES BONICIO, escrevendo sobre o "dever de colaboração" inserido do projeto do novo Código de Processo Civil, assevera que ele "pretende intensificar o dever de colaboração das partes, e que o rigor das regras atuais a esse respeito, praticamente repetidas no projeto, seria potencializado por uma nova diretriz de interpretação, marcadamente 'publicista"', objetivando 
Por outro lado, o mencionado projeto não prevê uma norma específica sobre o “dever de cooperação", embora ele possa ser extraído da interpretação sistemática do Código projetado, sobretudo à luz das garantias do contraditório e da ampla participação das partes na construção da decisão, pois "o juiz deixa de ser o autor único e solitário de suas decisões. A sentença e, de resto, as decisões judiciais passam a ser fruto de uma atividade conjunta". 311

Dessa forma, calcado no dever de colaboração, cabe ao órgão judicial, sempre visando garantir a igualdade substancial e a apuração dos fatos relevantes para o julgamento, "auxiliar as partes na superação das eventuais dificuldades que impeçam o exercício de direitos ou faculdades ou o cumprimento de ônus ou deveres processuais", 312 sendo a técnica de distribuição dinâmica do ônus da prova um importante instrumento para se alcançar esse objetivo. ${ }^{313}$

assegurar a celeridade do processo e a correta elucidação dos fatos para que a solução possa ser condizente com a verdade, e, portanto, "justa e efetiva" (Ensaio sobre o dever de colaboração das partes previsto no projeto do novo código de processo civil brasileiro. Revista de Processo, São Paulo: RT, v. 35, n. 190, p. 201-217, dez. 2010).

311 CUNHA, Leonardo Carneiro da. O processo civil no estado constitucional e os fundamentos do projeto do novo Código de Processo Civil brasileiro. Revista de Processo, São Paulo: RT, n. 209, p. 358 , jul. 2012. Exemplo dessa construção conjunta do processo é encontrado no $§ 3 .^{\circ}$ do artigo 364 do Código de Processo Civil projetado, que determina que, "se a causa for complexa, fática ou juridicamente, deverá o juiz designar audiência, para que o saneamento seja feito em cooperação com as partes. Nesta oportunidade, o juiz, se for o caso, convidará as partes a integrar ou esclarecer as suas alegações".

312 SOUSA, Miguel Teixeira de. Estudos sobre o novo processo civil, 2. ed. Lisboa: Lex, 1997, p. 67. Essa atuação colaborativa do juiz para com as partes não deve ser confundida, contudo, com um sistema inquisitorial, em que o juiz tem uma atuação investigativa plena, independentemente da vontade das partes. No modelo cooperativo, a atuação do juiz é integrativa e não mandamental, sendo um "um terceiro modelo de organização do processo", como define FREDIE DIDIER JÚNIOR, "com a inclusão do órgão jurisdicional no rol dos sujeitos do diálogo processual, e não mais como um mero espectador do duelo das partes. O contraditório volta a ser valorizado como instrumento indispensável ao aprimoramento da decisão judicial, e não apenas como uma regra formal que deveria ser observada para que a decisão fosse válida. A condução do processo deixa de ser determinada pela vontade das partes (marca do processo liberal dispositivo). Também não se pode afirmar que há uma condução inquisitorial do processo pelo órgão jurisdicional, em posição assimétrica em relação às partes. Buscase uma condução cooperativa do processo, sem destaques a algum dos sujeitos processuais". (Os três modelos de direito processual: inquisitivo, dispositivo e cooperativo. Revista de Processo, São Paulo: RT, v. 36, n. 198, p. 217, ago. 2011; grifos do autor). Confira-se, ainda, o entendimento de BARBOSA MOREIRA, para quem o incremento dos poderes do juiz não redunda em um "amesquinhamento do papel das partes", concluindo que "o lema do processo 'social' não é o da contraposição entre juiz e partes, e menos ainda o da opressão destas por aquele: apenas pode ser o da colaboração entre um e outras". (Os poderes do juiz na direção e na instrução do processo. Temas de direito processual: quarta série. São Paulo: Saraiva, 1989, p. 50; grifos do autor).

313 De acordo com Augusto Mario Morello, a técnica de dinamização encontra-se em total consonância com a ideia de processo civil pautado pela colaboração. (La prueba: tendencias modernas. 2. ed. Buenos Aires: Abeledo-Perrot, 2001, p. 86). Segundo o referido autor, seria mesmo possível denominar a técnica dinâmica como "modelo solidarista" de distribuição do ônus probatório, em que as partes não poderiam adotar uma conduta passiva, aguardando que seu adversário produza a prova, havendo mesmo um dever de colaboração com a descoberta dos fatos (ainda que contrários á 


\subsubsection{Dever processual de lealdade das partes}

As partes litigantes, embora tenham legitimidade para sustentar posições divergentes e conflitantes no processo, com ampla participação nos debates, dentro do modelo cooperativo que expusemos no item anterior, não podem se valer de artifícios escusos para obter êxito na demanda, sob o risco do completo desvirtuamento desse instrumento de solução de conflitos.

Os deveres decorrentes da lealdade processual impõem às partes uma atuação diligente e escorreita, sempre em favor da busca de uma melhor instrução probatória, para que o magistrado consiga atingir um grau de convencimento capaz de minimizar eventuais equívocos no momento de decidir.

Não se ignora que as partes sustentem posições divergentes e conflitantes no processo, o que é decorrência natural da sua incapacidade de se comporem quanto ao direito material debatido, mas nem por isso a conduta processual das partes é livre à prática das mais diversas arbitrariedades.

O processo não é um ringue de batalhas, tal qual nas lutas livres, em que os combatentes podem se valer de todos os meios, inclusive os ardis e escusos, para se sagrar vencedor da disputa. ${ }^{314}$

Coerente com o princípio democrático, de possibilidade de participação igualitária a todos, o processo deve ser pautado pelo dever de lealdade das partes durante todo o seu transcurso e em especial durante a fase instrutória, devendo ser exigido das partes um compromisso com a verdade, de forma que esta se revele ao juiz tão límpida quanto possível, fazendo com que este possa solucionar a lide com o melhor grau de convicção alcançável no caso concreto.

parte), por meio da produção de todos os meios de prova alcançáveis por cada uma das partes (Op. cit., p. 88-91), o que, por certo, soa um pouco exagerado, pois destoa do modelo essencialmente dialético que rege o nosso processo, mas, como vimos, dá um embasamento teórico para a dinamização, desde que realizada com a observância de requisitos objetivos e em situações específicas, como veremos a seguir.

314 PIERO CALAMANDREI, que compara o processo a um jogo, adverte que no jogo é lícito o concurso de habilidades, "ma non è permesso barare. Il processo non è soltanto scienza del diritto processuale, non è soltanto tecnica della sua applicazione pratica, ma è anche leale osservanza delle regole del giuoco, coiè fedeltà a quei canoni non scritti di correttezza professionale, che seconfine tra la elagante e pregevole maestria dello schermitore accorto e i goffi tranelli del truffatore" (Il processo come giuoco. Studi..., cit., v. 6, p. 51). 
Aliado a tal dever processual, o correto emprego do ônus da prova, sobretudo em sua função subjetiva de estruturação da prova, permite que o processo atinja os seus escopos jurídico, social e político, pacificando com a justiça.

Com efeito, ao subministrar o ônus da prova à luz do caso concreto, o juiz está potencializando a possibilidade de descoberta da realidade fática nessa demanda, pois o atribuirá à parte que tem melhores condições de produzir prova, e, portanto, melhores condições de esclarecer a situação fática debatida. Entretanto, a mera atribuição do ônus da prova a determinada parte não significa que ela necessariamente produzirá a prova, haja vista que a parte poderá não se desincumbir desse ônus e assumir o risco de tal ato, qual seja o não acolhimento da sua pretensão caso não reste provada por outros meios, com a permanência do estado de dívida do juiz.

O dever de lealdade das partes atua com "reforço" ao ônus da prova, porquanto ainda que a parte onerada decida nada fazer, por força do aludido dever de lealdade exigido dessa parte, ela também não poderá criar empecilhos à descoberta dos fatos promovida pelo juiz ou por seu adversário.

O artigo 14 do Código de Processo Civil, em seu inciso II, revela de forma expressa o dever de "proceder com lealdade e boa-fé", e o artigo 17 tipifica as condutas de litigância de má-fé, e as que nos interessam estão previstas nos incisos II, IV e V, que dizem respeito à observância da verdade e à conduta proba na participação das partes no processo.

A observância de tal dever, assim como a possibilidade de distribuição dinâmica do ônus da prova, em nosso entender, não conflitam com o direito de não produzir prova contra si mesmo (nemo tenetur se detegere), na medida em que este deve ser compreendido nos estritos limites da sua incidência e objetivo, consistente em proteger o indivíduo contra excessos cometidos pelo Estado ou por alguém em situação hierarquicamente superior. $^{315}$

315 Tratando especificamente sobre a incidência do princípio nemo tenetur se detegere no âmbito penal, MARIA ELIZABETH QUEIJO sustenta que "cuida-se do direito à não autoincriminação, que assegura esfera de liberdade ao indivíduo, oponível ao Estado, que não se resume ao direito ao silêncio. Parece acertado referido entendimento, de acordo com as notas características dos direitos fundamentais. Nelas se dá ênfase à proteção do indivíduo contra excessos e abusos por parte do Estado. Em suma: é 
Ademais, os deveres de lealdade exigidos da parte e a distribuição dinâmica do ônus da prova de nenhuma forma obrigam determinada parte a produzir prova contra si mesmo, mas apenas e tão somente exigem uma conduta de acordo com a verdade dos fatos, não retirando da parte o direito ao silêncio, o direito de não declarar contra si mesmo, de não confessar e/ou de não praticar comportamento ativo que possa lhe comprometer.

Ao se distribuir o ônus a determinada parte, impõe-lhe os riscos da não desincumbência, nada mais, nada menos. O que se espera com o emprego dessa técnica é que a parte aja e assim facilite a descoberta dos fatos, proibindo-lhe apenas que atue em sentido contrário, ou seja, que adote uma conduta contrária à adequada instrução probatória.

Por fim, vale retomar, de forma sucinta, as ideias expostas no item " 4.2 " deste trabalho, para reforçar a inexistência de conflito entre o dever de lealdade e a distribuição dinâmica do ônus da prova, de um lado, e a vedação de produzir prova contra si mesmo, de outro.

A técnica de distribuição dinâmica do ônus da prova não impõe à parte que se tomou onerada a prova das alegações da parte contrária, o que violaria o princípio da nemo tenetur se detegere, mas sim a prova das alegações formuladas por essa parte para desarticular as alegações da parte contrária. Ou seja, impõe-se à parte o ônus de provar as alegações que beneficiam a própria parte que se tornou onerada e jamais o ônus de provar as alegações da outra parte e que, em regra, lhe são prejudiciais.

resguardada, nos direitos fundamentais, a dignidade humana, sendo que ganha relevo a esfera atinente às ingerências do Estado. Nessa ótica, o princípio nemo tenetur se detegere, como direito fundamental, objetiva proteger o indivíduo contra excessos cometidos pelo Estado, na persecução penal, incluindo-se nele o resguardo contra violências físicas e morais, empregadas para compelir o indivíduo a cooperar na investigação e apuração de delitos, bem como contra métodos proibidos no interrogatório, sugestões e dissimulações. Como direito fundamental, o nemo tenetur se detegere insere-se entre os direitos de primeira geração, ou seja, entre os direitos da liberdade. $\mathrm{O}$ titular de tais direitos é o indivíduo diante do Estado" ( $O$ direito de não produzir prova contra si mesmo (o princípio 'nemo tenetur se detegere' e suas decorrências no processo penal). São Paulo: Saraiva, 2003. p. 5455). A par do questionamento sobre sua aplicabilidade no âmbito civil, o projeto do novo Código de Processo Civil consagra o instituto no âmbito civil, quando estabelece o dever de cooperação das partes na instrução probatória, confira-se: “Art. 376. Preservado o direito de não produzir prova contra si própria, incumbe à parte: I - comparecer em juízo, respondendo ao que lhe for interrogado; II colaborar com o juízo na realização de inspeção judicial que for considerada necessária; III - praticar o ato que the for determinado". Disponível em: <http://www.senado.gov.br/atividade/ materia/getPDF.asp?t=157884\&tp=1>. Acesso em: $10 \mathrm{dez} .2014$. 
Portanto, calcado no dever de lealdade das partes, o juiz, ao atribuir a determinada parte o ônus de provar suas alegações de fato que originalmente não precisariam ser provadas (porque o ônus incumbia primeiramente à parte contrária, quanto às suas alegações de fato), espera que a parte que se tornou onerada adote providências para se desincumbir de tal ônus, providências estas pautadas pelos deveres de dizer a verdade e de lealdade para com a parte contrária e o juízo, com o objetivo final de ampliação da cognição sobre os fatos controvertidos.

Enfim, é nesse contexto de participação democrática e cooperativo, preocupado em assegurar a igualdade material das partes e exigindo-lhes uma condução civilizada no curso processual, que a doutrina encontrou terreno fértil para reformular a técnica geral e abstrata de distribuição do ônus da prova, definindo a atribuição dos respectivos ônus probatórios das partes a partir do exame das reais possibilidades e capacidades probatórias de cada uma para, à luz do caso concreto, afastar, ao menos temporariamente e para a prova de determinadas alegações de fato específicas, o modelo estático de distribuição, atribuindo o ônus probatório à parte que se encontrar em melhores condições de realizar esse encargo para clareamento da situação fática.

Nos itens seguintes, procuraremos detalhar o funcionamento da técnica de distribuição dinâmica do ônus da prova, examinando as suas características fundamentais, seus requisitos, seu momento de incidência e limites, de modo que possamos estabelecer uma definição para a sua regra de aplicabilidade, traçando, ainda, um paralelo entre a técnica de dinamização e aquela prevista no Código de Defesa do Consumidor.

Por fim, trataremos da aplicabilidade dessa técnica no direito brasileiro e a sua previsão no projeto do novo Código de Processo Civil, bem como da influência dos poderes instrutórios do juiz sobre a técnica de distribuição dinâmica do ônus da prova.

\subsection{Características fundamentais}

O ponto inicial do nosso estudo deve ser a definição das características fundamentais da técnica, quais sejam: o dinamismo, a subsidiariedade, a excepcionalidade, a desigualdade da capacidade probatória das partes, a irrelevância da posição das partes na relação processual e a irrelevância da natureza do fato a ser provado. 


\subsubsection{Dinamismo}

O primeiro elemento identificador da técnica, que está inclusive no seu nome, é o dinamismo. Contudo, o que exatamente significa uma distribuição "dinâmica" dos ônus da prova?

A técnica em exame está calcada na ideia de que o ônus da prova, e aqui falamos de seu aspecto subjetivo (quem deve provar), ${ }^{316}$ em determinadas circunstâncias verificadas no caso concreto pode ser distribuído de forma diversa daquela originalmente prevista, o que torna a distribuição mutável, e daí a denominação "dinâmica". 317

O termo "dinamismo" também é empregado em contraposição à regra geral e abstrata de distribuição dos ônus da prova prevista na grande maioria dos ordenamentos jurídicos que atribui de forma fixa ("estática") o ônus da prova às partes. Ou seja, de um lado existe o modelo estático de distribuição dos ônus probatórios, que, em regra, não admite modificações e, em paralelo, ${ }^{318}$ há o modelo dinâmico de distribuição, em que, observados determinados requisitos, expostos a seguir, "quebra" a rigidez do modelo estático e atribui o ônus probatório de determinadas alegações de fato para a parte que pela regra estática não estava originalmente onerada.

316 A doutrina argentina, precursora da técnica da distribuição dinâmica do ônus da prova de maneira sistematizada e científica, sustenta, em verdade, que a distribuição dinâmica se dá sobre o aspecto objetivo do ônus da prova (regra de julgamento) e que somente deve ser aplicada no momento de decidir, se o arcabouço probatório se mostrar insuficiente para formação do convencimento do juiz. Com a devida vênia, não podemos concordar com essa visão, haja vista que se estaria abrindo grandes possibilidades de ofensa ao contraditório e ao próprio conceito de ônus, pois somente poderá sofrer uma desvantagem aquele que tinha a faculdade de agir, previamente conhecedor do seu ônus. PEYRANO sustenta que não haverá ofensa ao contraditório porque a técnica dinâmica é conhecida de todos e a parte deve produzir todas as provas previamente, para evitar o julgamento com base na regra da distribuição do ônus, que no caso concreto poderá ser dinâmica e incidir sobre aquele que não estava originalmente onerado (La doctrina de las cargas probatorias dinámicas y la máquina de impedir en materia jurídica. In: PEYRANO, Jorge Walter (Dir.); WHITE, Inés Lépori (Coord.). Cargas..., cit., p. 87-91).

317 "Se llama doctrina de las cargas probatorias dinámicas porque el 'onus probandi'se independiza de enfoques apriorísticos, es decir que se independiza del rol de actor o demandado de la parte en el proceso, y de los tipos de hechos a probar, para limitarse a indicar que la carga probatoria pesa sobre quien está em mejores condiciones técnicas, de hecho o profesionales para conducir la prueba respectiva" (AIRASCA, Ivana María. Reflexiones sobre la doctrina de las cargas probatorias dinámicas. In: PEYRANO, Jorge Walter (Dir.); WHITE, Inés Lépori (Coord.). Cargas..., cit., p. 136).

318 Como veremos em seguida, em um sistema que admite a distribuição dinâmica, os modelos estático e dinâmico coexistem, não havendo que falar em conflito de regras ou modelos reciprocamente excludentes. 
Os idealizadores da técnica dinâmica partem da ideia de processo como uma situação jurídica, desenvolvida originalmente por JAMES GOLDSCHMIDT para distinguir o processo (que é formado por expectativas, possibilidades e ônus, e, portanto, dinâmico), da relação de direito material que lhe dá sustento e que é fundada em obrigações e, portanto, estática. $^{319}$

Do conceito de dinamismo também podemos extrair a constante fluidez na distribuição dos ônus probatórios.

Com efeito, mesmo quando o magistrado adota a técnica de distribuição do ônus da prova em um dado momento processual (preferencialmente antes do início da instrução) e atribui o ônus da prova de forma diversa da regra geral, e no momento da produção probatória (e da desincumbência do ônus) a situação fática demonstrar que os requisitos que haviam autorizado a distribuição dinâmica já não se encontram presentes, desde que sem culpa da parte onerada, deverá o juiz "devolver" o ônus da prova à parte inicialmente onerada (e os riscos da não desincumbência).

Assim, de acordo com a técnica dinâmica, até que o juiz profira sentença (ou o Tribunal prolate Acórdão, naquilo em que se admite instrução probatória em segunda instância), os ônus da prova podem ser atribuídos a qualquer das partes, porém nunca estará indefinido, pois seja pela regra estática, seja por aplicação da regra dinâmica, alguma das partes sempre estará incumbida do ônus da prova.

\subsubsection{Subsidiariedade à regra estática de distribuição do ônus da prova e aos poderes instrutórios do juiz}

A segunda característica essencial da técnica de distribuição dinâmica dos ônus da prova é a sua subsidiariedade em relação à técnica estática, o que significa que somente se fará uso da técnica dinâmica quando a observância da regra estática se mostrar inócua

319 OSKAR VON BÜLOW, desde a segunda metade do século XIX, já defendia a distinção entre a relação de processo direito material e a relação de direito processual, uma vez que, enquanto aquela já surge como um ato consumado no debate judicial, esta é uma relação que avança gradativamente e se desenvolve de acordo com a evolução do processo, de forma que o processo deve ser tratado como um direito autônomo (La teoría de las excepciones procesales y los presupuestos procesales. Tradução M. A. R. Lichtschein. Buenos Aires: EJEA, 1964. p. 2). 
para o fim a que se destina, qual seja imbuir a parte onerada de produzir a prova que lhe compete.

Vale mais uma vez ressaltar que estamos nos referindo ao aspecto subjetivo do ônus da prova, pois somente vislumbramos a aplicação da técnica dinâmica se ela incidir nos dois aspectos do ônus da prova, e não apenas no aspecto objetivo, no momento de julgar a ação, como defende a doutrina argentina. ${ }^{320}$

Como veremos adiante, um dos requisitos para a aplicação da técnica de distribuição dinâmica do ônus da prova é a extrema dificuldade ou impossibilidade de a parte onerada produzir prova (“prova diabólica”). Quando o juiz constatar no caso concreto essa situação (e desde que preenchidos os demais requisitos), poderá afastar a incidência da regra geral (estática) e redistribuir o ônus da prova para a parte contrária.

Essa decisão de deslocamento do ônus probatório é pontual e específica ao ônus de produzir prova sobre determinada alegação de fato, permanecendo inalterada a regra estática quanto às demais alegações de fato que cada uma das partes terá que provar.

Vale dizer, a regra geral, abstrata e estática continua vigendo em relação aos ônus probatórios das demais alegações fáticas e apenas em relação àquela em que se verificar a aplicabilidade da regra dinâmica é que haverá a redistribuição do ônus, de modo que ambas as regras (estática e dinâmica) coexistirão no mesmo processo, porém incidentes sobre alegações de fato distintas, com a necessidade de se produzirem provas distintas.

Como consequência, caso a alegação de fato cujo ônus seja redistribuído por força de técnica dinâmica restar devidamente comprovada e a alegação de fato cujo ônus permanecer estático não restar comprovada no momento do julgamento, caso o estado de dúvida em relação à alegação de fato cujo ônus seguiu a regra geral não puder ser elidido pela prova das demais alegações fáticas, o juiz não julgará com base na regra de distribuição dinâmica do ônus da prova, mas sim na regra de distribuição estática, pois a

320 Vide nota 316 sobre a crítica quando ao momento de aplicação da teoria dinâmica da distribuição do ônus da prova pelos autores argentinos. 
ausência ou insuficiência de provas se deu em relação à alegação de fato cujo ônus permaneceu inerte.

A exposição de um exemplo típico pode elucidar essa situação.

Imaginemos uma ação indenizatória promovida em decorrência de procedimento cirúrgico, o qual supostamente causou danos estéticos e materiais ao paciente. Em sua defesa, o médico réu alega que não agiu com culpa e que inexistiu dano, razão pela qual a ação deve ser julgada improcedente.

No curso do processo, diante da impossibilidade de o paciente conhecer como se passou o ato cirúrgico, o juiz vislumbra a aplicação da técnica da distribuição dinâmica do ônus da prova e determina que o réu faça prova de que agiu diligentemente e adotou todas as técnicas médicas recomendadas e usuais para aquela espécie de cirurgia, por se encontrar em melhores condições de fazê-lo. Não obstante essa redistribuição do ônus probatório, o autor continua onerado pela prova dos danos sofridos e negados pelo réu.

Durante a instrução probatória, o réu não consegue trazer elementos que convençam o magistrado de sua conduta diligente no ato cirúrgico, e, da mesma forma, o autor não consegue fazer a prova dos danos. Nessa hipótese, o magistrado deverá julgar a ação improcedente, com base na regra estática de distribuição do ônus da prova, pois o autor, incumbido do ônus de provar os danos experimentados (fato constitutivo do seu direito), assim não o fez, de sorte que, ainda que no curso do processo o juiz tenha se valido da técnica de dinamização, a insuficiência ou inexistência de prova se deu quanto a uma alegação de fato cujo ônus foi distribuído pela regra estática.

Dessa forma, equivocam-se aqueles que sustentam a incompatibilidade entre os modelos estático e dinâmico, como se eles não pudessem coexistir. ${ }^{321}$

321 Entendimento que é sustentado por EDUARDO HENRIQUE DE OLIVEIRA YOSHIKAWA. Nas palavras do aludido autor, “[...] ainda que, de forma residual, subsistisse alguma dificuldade na aquisição de provas pelo processo que não pudesse ser solucionada adequadamente pelas técnicas já previstas pelo Código de Processo Civil, não se justificaria a adoção da teoria da distribuição dinâmica do ônus da prova [...]. A maior ou menor dificuldade de produção da prova, por si só, jamais poderia ser utilizada como fundamento para a alteração do ônus da prova estabelecido em lei (seja a regra do art. 333 do CPC, seja a constante em lei extravagante), que conforme já ressaltado implica em dispensa da prova do fato alegado pela parte a quem ele beneficia, pois isto resultaria em flagrante ofensa ao princípio constitucional da isonomia, que exige da parte prova de suas alegações precisamente porque, à míngua 
A distribuição do ônus da prova a partir do modelo dinâmico, complementar e subsidiário ao modelo estático, analisa cada alegação de fato individual e concretamente, de forma que apenas haverá redistribuição em relação a determinadas alegações de fato, na hipótese de se verificar a presença dos requisitos autorizadores, que serão detalhadamente examinados a seguir. ${ }^{322}$

\subsubsection{Excepcionalidade}

A terceira característica marcante da técnica de distribuição dinâmica do ônus da prova é a sua excepcionalidade, aspecto intimamente relacionado à subsidiariedade.

Tendo em vista que a técnica de dinamização não exclui a incidência da regra geral e abstrata da distribuição dos ônus probatórios e atua de forma subsidiária, forçoso reconhecer que a aplicabilidade da regra dinâmica será excepcional.

E a razão dessa excepcionalidade reside no fato de que os sistemas processuais precisam trazer aos jurisdicionados certo grau de segurança ${ }^{323}$ e, embora haja sistemas

de prova, não lhe seria lícito dar mais valor à palavra do autor do que à do réu, sejam eles quem forem. Ora, se a maior ou menor facilidade em produzir a prova [...] não foi o critério estabelecido pelo legislador para distribuir o ônus da prova (e sim o interesse na aplicação de determinada regra jurídica), não faz sentido que a variação, no caso concreto, dessa circunstância, dê ensejo à alteração do quanto estabelecido em lei. Não haveria, na hipótese, a correção ou adaptação, no caso concreto, do critério estabelecido pelo legislador, por não ser possível a este prever todas as situações que na prática poderiam surgir, mas a sua alteração. (Considerações..., cit., p. 143-144, grifos do autor). Em nosso sentir, há dois equívocos no pensamento acima transcrito, quais sejam: a possível quebra da "isonomia" e a alteração do critério de distribuição. Em relação ao primeiro, já sustentamos anteriormente que é exatamente para assegurar a isonomia material que a regra do ônus da prova deve poder adaptar-se ao caso concreto, tratando desigualmente os desiguais, na medida de sua desigualdade. Já quanto a uma "alteração" no critério de distribuição, também não entendemos adequada a afirmação, pois seria mesmo possível se imaginar um interesse de ambas as partes na prova (de uma para confirmar a alegação de fato e da outra para refutá-la), de como que a técnica dinâmica, em verdade, agrega mais um elemento ao critério de distribuição (a capacidade probatória), de modo a permitir que a apuração dos fatos relevantes da causa seja a mais completa possível, evitando-se, na medida do possível, as decisões calcadas na regra objetiva de distribuição do ônus da prova.

322 Essa conclusão nos leva imediatamente à próxima característica da teoria da distribuição dinâmica do ônus da prova, que é a sua excepcionalidade.

323 ROSENBERG defende a segurança jurídica como a principal razão para se estabelecer um modelo prévio de distribuição dos ônus probatórios entre as partes, nos seguintes termos: "La regulación de la carga de la prueba debe hacerse mediante normas jurídicas cuya aplicación debe estar sometida a la revisión por el tribunal correspondiente, y esta regulación debe conducir a un resultado determinado, independiente de las contingencias del proceso particular, siendo un guía seguro para el juez con el cual las partes pueden contar ya antes de trabar el proceso. [...] La distribución proporcionada e 
como o alemão, que não possuem uma norma expressa sobre a distribuição do ônus probatório, é prudente que as partes já saibam, de antemão, quais as suas "expectativas, possibilidades e ônus" na relação processual, como ensina JAMES GOLDSCHMIDT. ${ }^{324}$

Ocorre que, como exposto anteriormente, ${ }^{325}$ ainda que a regra geral e abstrata seja capaz de resolver uma gama de situações, em determinados casos especiais e excepcionais, em que a disparidade de forças entre os litigantes praticamente inviabiliza as chances de determinada parte em obter êxito, pelo simples fato de que não dispõe de meios para se desincumbir dos seus ônus probatórios, é preciso que seja autorizada a flexibilização da distribuição dos ônus probatórios, seja pela incidência de técnicas como as que analisaremos no Capítulo 6, seja pelo uso da técnica de distribuição dinâmica dos ônus probatórios que ora se examina. ${ }^{326}$

A regra dinâmica, portanto, terá seu campo de incidência restrito a essas situações excepcionais e casuísticas, verificadas em cada caso concreto e em relação a cada alegação de fato das partes. Naquilo em que a regra dinâmica não incidir, ou seja, nas situações ordinárias, a regra estática e previamente estabelecida no Código de Processo Civil (ou no Código Civil, como na Itália), ${ }^{327}$ ou mesmo decorrente do "senso comum" (como na Alemanha), ${ }^{328}$ continuará válida e eficaz, seja no seu aspecto subjetivo ou no seu aspecto objetivo.

invariable de la carga de la prueba es un postulado de la seguridad jurídica [...]" (La carga ..., cit., p. 84-85).

$324 \quad$ Derecho..., cit., p. 8.

325 Vide item "3.4" do Capítulo 3.

326 É voz corrente na doutrina (mesmo entre os críticos) que a técnica de distribuição dinâmica do ônus da prova tem aplicação restrita e excepcional. Nesse sentido, PEYRANO adverte que "[...] su aplicación es procedente sólo in extremis; vale decir, cuando la utilización del reparto legalmente previsto del 'onus probandi' genera consecuencias claramente inconvenientes e inicuas" (Nuevos lineamentos de las cargas probatorias dinámicas. In: PEYRANO, Jorge Walter (Dir.); WHITE, Inés Lépori (Coord.). Cargas probatórias dinâmicas. Santa Fé: Rubinzal-Culzoni, 2008. p. 21). Entre os críticos "parciais" da teoria dinâmica, a excepcionalidade deve ser ainda mais severa, haja vista o risco de ocorrência de arbitrariedades [KNIJNIK, Danilo. As (perigosíssimas) doutrinas do "ônus dinâmico da prova" e a da "situação de senso comum" como instrumentos para assegurar o acesso à justiça e superar a probatio diabolica. In: FUX, Luiz; NERY JUNIOR, Nelson; e WAMBIER, Teresa Arruda Alvim (Coord.). Processo e Constituição: estudos em homenagem ao Professor José Carlos Barbosa Moreira. São Paulo: RT, 2006, p. 951].

Art. 2.697. Onere della prova

Chi vuol far valere un diritto in giudizio (Cod. Proc. Civ. 163) deve provare i fatti che ne costituiscono il fondamento (Cod. Proc. Civ. 115). Chi eccepisce l'inefficacia di tali fatti ovvero eccepisce che il diritto si è modificato o estinto deve provare i fatti su cui l'eccezione si fonda".

328 Como adverte MiChELli, o projeto preliminar do Código Civil alemão previa dois parágrafos regulando o ônus da prova, mas na redação final se entendeu que tais regras seriam inúteis, pois a 
Por outro lado, não obstante o seu caráter subsidiário e excepcional, sempre que da análise do caso concreto o juiz identificar a presença dos requisitos autorizadores da distribuição dinâmica ele terá o dever de assim agir, mediante decisão motivada e possibilitando àquela parte que se tornou nesse momento onerada a possibilidade de se desincumbir desse ônus, sob pena de, assim não o fazendo, contrariar os princípios e as garantias do contraditório e do processo participativo e igualitário que embasam o processo constitucional e a técnica de distribuição dinâmica de ônus de prova.

Por fim, conforme restou assentado nas conclusões do XVII Congreso Nacional de Derecho Procesal, ocorrido em 1993 na Argentina, a aplicabilidade da técnica de distribuição dinâmica dos ônus probatórios depende de uma análise criteriosa e cuidadosa do magistrado, não apenas para identificar a desigualdade entre as partes, mas, sobretudo, em face do risco de manipulação da parte que será onerada sobre o conteúdo da prova, ${ }^{329}$ o que reforça a sua natureza excepcional e subsidiária.

\subsubsection{Capacidade das partes de produzir provas}

Outro elemento característico e talvez o mais marcante da regra de distribuição dinâmica dos ônus da prova, e que o diferencia das demais técnicas modernas, como já tivemos oportunidade de ressaltar no item “3.2” do Capítulo 3, é a apuração da capacidade das partes de produzir provas.

Segundo a técnica estática, as partes repartem igualmente os esforços probatórios, de acordo com os respectivos interesses perseguidos, sem qualquer preocupação com a capacidade probatória das partes.

Ocorre que, em determinadas circunstâncias, essa isonomia formal entre as partes litigantes não se realiza no caso concreto, havendo, em verdade, uma disparidade de

regra de distribuição do ônus da prova é uma decorrência lógica do conjunto de normas substanciais e da própria estrutura do processo civil (La carga..., cit., p. 48-49). 
forças dessas partes em produzir as provas necessárias para se alcançar o ideal de verdade almejado.

A forma de incentivar a colaboração das partes (sobretudo porque não é de se esperar que as partes assim o façam por livre e espontânea vontade, dado o caráter dialético do processo civil), ${ }^{330}$ e de se equilibrar essa desigualdade concreta, se dá por meio da atribuição de ônus probatórios àquela parte que se encontra em melhores condições de produzir a prova, pela técnica de dinamização, em estrita observância ao ideal de Justiça extraído dos ensinamentos de RUI BARBOSA de tratar igualmente os iguais e tratar desigualmente os desiguais, na medida de sua desigualdade. ${ }^{331}$

No entanto, quais critérios devem ser utilizados para a averiguação da capacidade das partes de produzir provas?

JORGE W. PEYRANO ${ }^{332}$ sustenta que essa capacidade pode ser aferida das mais diversas formas, seja pelo fato de a parte possuir melhores condições profissionais, seja por ter melhores condições técnicas, seja ainda por dispor de melhores condições fáticas para a produção da prova.

A melhor condição profissional pode ser facilmente constatada nas ações de responsabilidade civil por erro de profissional liberal, como o caso de erro médico citado anteriormente e do qual, aliás, surgiu a primeira decisão na Argentina, em 1978, aplicando a técnica de distribuição dinâmica do onus probandi. ${ }^{333}$

330 Como lembra LIEBMAN, "o processo civil, com sua estrutura contraditória em que a cada uma das partes se atribui a tarefa de sustentar as suas próprias razões, é essencialmente refratário a uma rigorosa disciplina moralista do comportamento daquelas. Se cada litigante pode contar, para vencer, apenas com a própria capacidade de explorar os elementos e os argumentos favoráveis, não se pode pretender que forneça também os que lhe são desfavoráveis e poderiam favorecer o adversário" (Manual..., cit., v. 1, p. 124).

331 Oração aos moços. Disponível em: <http://www.casaruibarbosa.gov.br/dados/doc/artigos/ rui_barbosa/fcrb_RuiBarbosa_Oracao_aos_mocos.pdf >. Acesso em: 25 nov. 2014.

332 Nuevos lineamentos..., cit., p. 20.

333 Trata-se de uma sentença proferida pelo Juzgado de Primera Instancia de Distrito en lo Civil y Comercial de la Quinta Nominación de la ciudad de Rosario, que foi posteriormente confirmada pela Cámara de Apelaciones en lo Civil y Comercial de la ciudad de Rosario (AIRASCA, Ivana María. Reflexiones..., cit., p. 135). INÉS LÉPORI WHITE, por seu turno, sustenta que o primeiro precedente a aplicar a teoria, embora ainda sem essa denominação, foi uma decisão da Corte Suprema de Justicia de la Nación, de 21 de junho de 1957, sobre enriquecimento ilícito de funcionários públicos, atribuindo o ônus da prova de que o enriquecimento foi lícito aos próprios funcionários públicos 
Por certo, o profissional liberal, que é réu na ação, em geral tem melhores condições de demonstrar que adotou todas as providências e diligências necessárias durante $\mathrm{o}$ ato questionado e que, portanto, inexistiu o alegado erro. Se constatada efetivamente essa situação de desigualdade, em decorrência da capacidade profissional das partes, a teoria da distribuição dinâmica do ônus da prova será aplicável.

A melhor condição técnica para produzir prova verifica-se nas situações em que determinada prova depende de conhecimentos científicos específicos, que naquela circunstância apenas a parte não inicialmente onerada poderia produzir, como no caso de comprovação dos efeitos fitoterápicos de determinada espécie vegetal que foi objeto de longos anos de estudo por aquele que é réu em uma ação em que esses efeitos são questionados. $^{334}$

Já a melhor condição fática na obtenção da prova se desdobra em duas: a detenção do conhecimento direto dos fatos (fonte de prova) e a melhor condição da parte em trazer os elementos probatórios (meios de prova). ${ }^{335}$

Se a parte tem conhecimento direto dos fatos controvertidos, não se deve admitir que simplesmente se cale ou se omita, porque o ônus da prova sobre tais fatos não lhe incumbia. Esse ônus deverá ser redistribuído e a parte deverá trazer a prova dos fatos sobre os quais tenha conhecimento, sob o risco de a dúvida lhe ser desfavorável no momento da sentença.

Da mesma forma, se a parte possui ou sabe onde se encontram os meios de prova, a ela deve incumbir o ônus de trazer e produzir essas provas. Trata-se de hipótese semelhante à exibição de documento ou coisa que será examinada no item "6.3.1" do

(Cargas probatorias dinámicas. In: PEYRANO, Jorge Walter (Dir.); WHITE, Inés Lépori (Coord.). Cargas..., cit., p. 71).

334 Essa hipótese equivale à "assimetria de informações" utilizada por HEITOR SICA para designar a hipossuficiência técnica do consumidor, ligada à ideia de posse de conhecimento e de informação, que nas relações de consumo está concentrada nas mãos do fornecedor (Questões velhas..., cit., p. 51-52).

335 Como propõe SERGIO José BARBERIO, "es decir que, en virtud del rol que desempeñó en el hecho generador de la controversia, por estar en posesión de la cosa o instrumento probatorio o por ser el único que 'dispone' de la prueba [...]". E completa, "corresponden mayores cargas a quien dispone de mejores posibilidades en razón de la posesión de medios idóneos de prueba [...]” (Cargas..., cit., p. 101). 
Capítulo 6, pois nesta a parte tem em seu poder a fonte e o meio de prova e sua exibição é a exigida, sob pena de se presumirem verdadeiras as alegações da parte contrária.

Além da apuração da capacidade das partes em produzir provas a partir de aspectos profissionais, técnico-informacionais e fáticos, alguns autores também sustentam que a desigualdade pode se dar em termos econômicos. ${ }^{336}$

Com base nesse critério de distinção de capacidade das partes em produzir a prova, a parte dotada de mais recursos financeiros para custear a elaboração da prova também deve ser encarregada do respectivo ônus probatório.

Esse critério, também originalmente sustentado como definidor da hipossuficiência do consumidor do Código de Defesa do Consumidor, ${ }^{337}$ foi duramente criticado na doutrina pátria no que toca às relações de consumo, pois a disparidade financeira não elimina eventual deficiência técnico-informacional do consumidor perante o fornecedor.

Também aqui a crítica nos parece pertinente, pois o que realmente distingue a condição das partes de produzir a prova é o conhecimento acerca do thema probandum e o acesso à fonte e aos meios de prova.

Ainda que com maior disponibilidade financeira a prova possa ser mais bem produzida, com a contratação de profissionais mais qualificados, em relação a

336 Essa possibilidade é levantada por SERGIO José BARBERIO (Cargas..., cit., p. 101). No mesmo sentido é o posicionamento de JUAN TRUJILlO CABRERA, ao asseverar que: "En términos simplificados la aplicación de la carga dinámica de la prueba se justifica cuando los costos de producción probatoria son menores para una de las partes en relación con la otra, ya sea por razones de disponibilidad o posesión del medio, por facilidades técnicas, capacidad económica o cualquier otro motivo" (La carga dinámica de la prueba. Bogotá: Leyer, 2006. p. 187; grifos do autor). No direito pátrio, também encontramos alguns autores que sustentam a dinamização em decorrência da desigualdade econômica das partes, como ANTONio DANILO Moura DE AZEVEDo (A aplicabilidade..., cit., p. 22), ARTUR CARPES (A distribuição dinâmica do ônus da prova no formalismo-valorativo. Revista da Ajuris, Porto Alegre: Ajuris, v. 33, n. 104, p. 9-18, dez. 2006) e SUZANA SANTI CREMASCO (A distribuição..., cit., p. 86).

337 Como já expusemos neste trabalho, nas primeiras edições do Código brasileiro de Defesa do Consumidor comentado pelos autores do anteprojeto, o Professor KAZUO defendia que a hipossuficiência prevista na norma era apenas a econômica, equivalente àquela prevista na Lei $\mathrm{n}^{\circ}$ 1.060/1950, mas reviu sua posição para qualificar a hipossuficiência como uma "diminuição da capacidade do consumidor, não apenas no aspecto econômico, mas a social, de informações, de educação, de participação, de associação, entre outros" (Código..., cit., p. 714). 
determinadas circunstâncias fáticas, como o que se passou durante a operação de um paciente em um centro cirúrgico, o fato de o paciente ter, eventualmente, melhores condições financeiras que o médico que lhe operou ou este ter melhores condições financeiras deve ser irrelevante para a distribuição dos ônus probatórios.

Portanto, parece-nos que a limitação a aspectos profissionais, técnicoinformacionais e fáticos são os que melhor definem a capacidade das partes de produzir provas, de forma que, quando se tratar de hipótese de aplicação da técnica de distribuição dinâmica do ônus da prova, o ônus deverá ser atribuído àquela parte que, no caso concreto, esteja em melhores condições de produzir a prova sobre a questão fática, seja por possuir melhores conhecimentos técnicos e profissionais que a parte contrária, seja por ter melhor acesso às fontes e aos meios de prova.

\subsubsection{Irrelevância da posição das partes na relação processual}

A quinta característica que podemos extrair da técnica de distribuição dinâmica dos ônus probatórios é a irrelevância da posição ocupada por cada uma das partes na relação processual, ou seja, a distribuição do ônus probatório não se encontra vinculada ao fato de a parte ser autora ou ré na ação, tal como ocorre no modelo atualmente vigente no Código de Processo Civil, que vincula a posição das partes à natureza dos fatos a serem provados.

O modelo adotado pelo legislador pátrio, insculpido no artigo 333 e influenciado essencialmente pelo pensamento de CHIOVENDA, ${ }^{338}$ prevê expressamente que cabe ao "autor" a prova do fato construtivo do seu direito (inciso I) e ao "réu", a prova dos fatos impeditivos, medicativos e extintivos (inciso II).

Como se vê, a posição das partes assume papel de relevância no momento de distribuição do ônus probatórios. 339

338 Vide item "3.4" do Capítulo 3, no qual discorremos de forma mais detalhada e profunda sobre o modelo vigente de distribuição do ônus probatório.

339 Em modelos mais modernos, como de RosENBERG e ECHANDíA, examinados nos itens "3.3.8" e “3.3.10” a posição das partes no processo não é considerado elemento essencial para fins de distribuição dos ônus probatórios. Já para MICHELLI, a posição das partes continua sendo um elemento 
Já na técnica dinâmica, a posição ocupada pelas partes na relação processual não tem qualquer papel na determinação da distribuição dos respectivos ônus da prova, pois estes são atribuídos às partes a partir da análise da efetiva capacidade das partes em produzir provas e, assim, se desincumbir dos ônus que lhe foram impostos em determinado momento do processo.

Da mesma forma, é irrelevante para a técnica dinâmica qual das partes formulou a alegação de fato e qual das partes a impugnou, tornando uma questão fática dependente de comprovação. ${ }^{340}$ uma vez que a atribuição dos ônus probatórios se dá tomando-se em consideração o desequilíbrio substancial entre as partes para produzir a prova de cada questão de fato relevante, a partir das suas respectivas alegações.

Assim, pela regra de distribuição dinâmica do ônus da prova, a fixação prévia da posição das partes (essencial para a formação da relação processual), que define a ordem e o conteúdo da distribuição do ônus probatório no modelo estático, não terá qualquer interferência no momento de atribuição de ônus probatório ao autor e ao réu, podendo ocorrer de o autor ter que provar a não ocorrência da questão fática suscitada pelo réu ou vice-versa.

Essa constatação revela que a dinamização da distribuição de ônus probatórios não é uma mera "inversão" do ônus da prova, uma vez que não se trata de simplesmente atribuir o mesmo ônus da prova que cabia à parte originalmente onerada para a outra parte, pois, como já ressaltamos anteriormente, se assim fosse, a parte originalmente onerada teria que fazer prova contra os seus interesses, o que se revela um verdadeiro contrassenso, proibido pelo nemo tenetur se detegere.

Tal como ocorre na redistribuição do ônus da prova prevista no Código de Defesa do Consumidor, no emprego da técnica de dinamização, o ônus da prova é atribuído àquela parte que esteja em melhores condições de demonstrar o fato e revelar a verdade, cabendo-lhe a prova de que determinada questão fática se deu deste ou daquele

relevante na determinação dos efeitos jurídicos pretendidos e, consequentemente, na distribuição dos ônus probatórios (La carga..., cit., p. 386-390 e 437).

340 Essa afirmação é parcialmente verdadeira, pois somente será irrelevante saber quem desincumbiu o ônus de afirmar após a verificação da presença dos requisitos autorizadores da aplicação da técnica dinâmica. Antes, cada uma das partes tem o ônus de formular todas as alegações na defesa dos seus interesses. 
modo, conforme os seus interesses no resultado do processo, e não simplesmente fazer a prova da alegação de fato da parte contrária, transferindo-lhe o risco de, não sendo capaz de elidir o estado de dúvida, arcar com uma decisão desfavorável.

\subsubsection{Irrelevância da natureza do fato a ser provado}

O sexto elemento caracterizador da técnica de distribuição dinâmica do ônus da prova é o seu desvencilhamento da natureza do fato a ser provado.

Não é demais relembrar que o modelo vigente em nosso direito processual civil atribui o ônus da prova dos fatos "constitutivos" ao autor (inciso I do artigo 333) e o ônus da prova dos fatos impeditivos, modificativos ou extintivos ao réu (inciso II do artigo 333).

Em momento anterior desta dissertação, ${ }^{341}$ já tivemos a oportunidade de expor o correto entendimento que deve ser seguido para a aplicação da regra atual de distribuir o ônus da prova conforme a natureza dos fatos, bem como de sua impropriedade, a justificar um aperfeiçoamento da técnica e a admissibilidade de regras de flexibilização.

Pela técnica de distribuição dinâmica de ônus da prova, a natureza dos fatos a serem provados não tem qualquer influência na distribuição, pois, assim como afirmamos no item precedente, não interessa saber se as alegações de fato se referem a eventos com eficácia constitutiva, impeditiva, modificativa ou extintiva, mas apenas deverá ser levada em consideração no momento da distribuição dos ônus probatórios a viabilidade de essa prova ser produzida, de acordo com a capacidade probatória das partes.

Desse modo, é perfeitamente condizente com a técnica da distribuição dinâmica dos ônus probatórios que o autor venha a se tornar onerado pela prova das alegações de fato que formulou contra as alegações de fato do réu, para demonstrar que os fatos impeditivos, modificativos e/ou extintivos não se configuraram, assim como o réu poderá ser incumbido da prova da alegação de fato por ele formulada contra o fato constitutivo do autor e que comprove a sua não ocorrência.

$341 \quad$ Vide item “3.5” do Capítulo 3. 
O enfoque da técnica dinâmica está na análise do caso concreto e na busca da efetiva obtenção da prova e, tanto quanto possível, do esclarecimento dos fatos relevantes e da verdade, sem que esteja vinculado a modelos apriorísticos de distribuição dos ônus da prova. O interesse das partes em provar as alegações de fato que fundamentam as suas respectivas pretensões, mola propulsora da maioria das regras estáticas de distribuição do ônus da prova, é substituído por um interesse geral de apuração dos fatos, mediante um processo participativo, colaborativo e, principalmente, igualitário.

Portanto, ambos os critérios atualmente previstos no Código de Processo Civil (posição da partes e natureza dos fatos) não terão qualquer função no momento em que o juiz decidir pela incidência da regra de distribuição dinâmica do ônus da prova, que terá como premissa a desigualdade na capacidade técnico-informacional das partes de produzir provas, sem prejuízo de sua manutenção dos respectivos ônus probatórios em relação às alegações de fato não submetidas à regra dinâmica que, como vimos, continuarão regradas pela regra geral e abstrata de distribuição.

\subsection{Requisitos condicionantes ao emprego da técnica de distribuição dinâmica do ônus da prova}

Embora a técnica dinâmica seja de grande valia para a "estruturação da atividade probatória das partes" ${ }^{\text {342 }}$ (aspecto subjetivo do ônus da prova), é preciso que sejam estabelecidos rigorosos requisitos condicionantes à sua aplicabilidade, igualmente amparados por princípios constitucionais, para que a busca cega e inconsequente da apuração dos fatos não se transforme em arbitrariedade, direcionamento do resultado do processo e injustiça. ${ }^{343}$

Seguindo nossa proposta técnico-científica, podemos dividir esses requisitos em dois grandes grupos: os requisitos intrínsecos e os requisitos extrínsecos, os quais ainda receberão subdivisões para tornar a exposição mais didática.

\footnotetext{
342 A expressão foi cunhada por ARTUR CARPES (Ônus dinâmico..., cit., p. 71).

343 Já nos referimos anteriormente à excepcionalidade da técnica de distribuição dinâmica dos ônus probatórios (vide item “6.2.3”). DANILO KNIJNIK expôs essa preocupação de forma clara ao denominar de "perigosíssima" a técnica de dinamização [As (perigosíssimas)..., cit., p. 942], assim como também é um tema recorrente no trabalho de YosHIKAWA, que defende o uso racional e controlado da técnica, sempre em situações excepcionais (Considerações..., cit., p. 134-149).
} 
Entre os requisitos intrínsecos deverão ser analisadas: (i) a inviabilidade da utilização da técnica geral e abstrata de distribuição do ônus da prova; (ii) a constatação da impossibilidade ou extrema dificuldade de uma parte e a facilidade de outra parte na produção de prova (vedação da prova diabólica inversa); (iii) inexistência de culpa da parte originalmente onerada pela dificuldade ou impossibilidade da produção de prova; (iv) a verossimilhança das alegações de fato objeto da prova; e (v) o não cabimento de outras técnicas de flexibilização da distribuição do ônus da prova e/ou a impossibilidade prática de o juiz se valer dos seus poderes instrutórios.

No tocante aos requisitos extrínsecos, abordaremos: (i) a necessidade de decisão judicial fundamentada para deslocamento do ônus probatório; (ii) a necessidade do prévio contraditório sobre a aplicabilidade ou não da distribuição dinâmica; e (iii) a necessidade de concessão de oportunidade para a parte onerada produzir a prova e tentar se desincumbir do ônus.

Com o estabelecimento desses requisitos, entendemos que a técnica dinâmica deixa de ser "perigosíssima", como a denominou KNIJNIK, ${ }^{344}$ e passa a ser um importante instrumento para potencialização da produção probatória, retirando as partes de ostracismos estrategicamente planejados à luz de regras apriorísticas (e muitas vezes ineficientes) de "divisão de trabalho", reduzindo as indesejadas situações de dúvida do magistrado, que levam a decisões formalmente corretas, mas desprovidas de efetividade e justiça.

\subsubsection{Inviabilidade do uso da técnica geral e abstrata}

O primeiro dos requisitos condicionantes à aplicabilidade da técnica de distribuição dinâmica do ônus da prova é a constatação, pelo juiz, da inviabilidade da obtenção da prova por meio da distribuição estática do ônus probatório.

Em verdade, ao definir como "perigosíssima", o autor gaúcho apenas ressalta a importância de se conhecer os limites materiais e formais para a correta aplicação da técnica dinâmica, a qual acolhe como legítima no direito brasileiro, sobretudo porque, "de há muito, reconhece ao juiz iniciativas probatórias para garantir a igualdade substancial entre os litigantes, não havendo por que essa mesma igualdade não se refletir no plano do ônus probatório" [As (perigosíssimas)..., cit., p. 947]. 
Ao tratarmos dos elementos caracterizadores da técnica dinâmica, verificamos que ela é subsidiária e excepcional, ou seja, embora coexista com a técnica geral e estática, seu campo de incidência é extremamente restrito, e somente nos casos em que a imposição do ônus pela regra ordinária se mostrar inútil para a produção da prova (aspecto subjetivo do ônus da prova), em face da impossibilidade ou dificuldade da parte originalmente onerada de produzi-la, é que o magistrado deverá cogitar da aplicabilidade da regra dinâmica.

Não se trata de uma mera faculdade do juiz, mas de um poder-dever de assim agir se verificados todos os requisitos condicionantes ora expostos, cumulativamente, impulsionando aquela parte que se encontra em melhores condições para agir, pela imposição de um ônus que originalmente não possuía e de todos os riscos dele inerentes.

Ainda que se propague o dever de obediência aos princípios da cooperação na instrução probatória e de lealdade processual, seria pueril imaginar que uma parte, sem que sofra o peso de uma desvantagem, irá se dispor a produzir prova de alegações fáticas formuladas contra as alegações da parte contrária, quando sabedor que tal ônus não lhe incumbe, sobretudo quanto tal prova seja complexa e exija um elevado dispêndio de tempo e dinheiro, sendo mais conveniente acreditar que a parte onerada não conseguirá se desincumbir do seu ônus.

A técnica de distribuição dinâmica dos ônus da prova surge como o propulsor de transformação: a parte deixa de ter o benefício da dúvida para responder diretamente pelo risco da derrota caso não se desincumba do ônus que lhe é imposto.

Nas situações em que a prova se revela impossível ou extremamente difícil para a parte onerada, o uso da técnica de dinamização da distribuição dos ônus probatórios se torna ainda mais relevante e necessário, sob pena de, assim não o fazendo, o magistrado inviabilizar à parte legalmente onerada o acesso ao Poder Judiciário e à tutela jurisdicional.

Por tais razões, como medida preventiva a um julgamento fundamentado na regra de distribuição de ônus da prova (aspecto objetivo), o magistrado deve se valer, no que couber, dos seus poderes instrutórios, dos meios de flexibilização da distribuição do ônus da prova, quando cabíveis, e/ou da técnica dinâmica de redistribuição dos ônus 
probatórios, sempre que a regra predefinida se tornar inócua, pois somente deve-se cogitar

de ônus e sanções se a parte puder se desincumbir do primeiro para evitar o segundo. ${ }^{345}$

\subsubsection{Desigualdade na capacidade de produzir prova e a vedação da prova diabólica (direta ou inversa)}

O segundo requisito a ser analisado pelo magistrado antes da aplicação de distribuição dinâmica do ônus da prova é a capacidade das partes de produzir a prova, que está intimamente relacionada ao primeiro requisito.

Se as capacidades probatórias das partes forem equivalentes, não se trata de hipótese de incidência da técnica dinâmica, mas de manutenção da regra geral e abstrata, cabendo à parte originalmente onerada prover os meios probatórios necessários à formação do convencimento do juiz, sob o risco de sucumbir.

Entretanto, pode acontecer de o magistrado constatar que a parte abstratamente onerada encontra-se em estado de extrema dificuldade ou impossibilidade de produzir a prova de suas alegações de fato, em uma situação que se caracteriza como "prova diabólica". 346

Diante de tal quadro, que, por certo, deverá ser devidamente comprovado pela parte ${ }^{347}$ o julgador necessitará verificar a situação da parte contrária e sua capacidade de

345 Como sustentamos no item "2.1", os ônus processuais são espécie do gênero faculdade, sendo imprescindível a liberdade de opção entre o agir e o omitir-se, arcando cada parte com as consequências de suas escolhas. Se a parte não tiver a faculdade de praticar o ato, os efeitos negativos que lhe serão aplicados não decorrem de um ônus, mas de um poder de imposição ou de um "ato devido", como denomina CARNELUTTI, diferenciando dos "atos necessários" (Sistema..., cit., v. 2, p. 73-84). Como adverte HEITOR SICA, "a ideia de ônus, que é ínsita à maioria dos atos que as partes praticam no processo, traz consigo, necessariamente, a de princípio dispositivo. De fato, se a parte pode escolher exercer determinada atividade ou não, é porque o princípio dispositivo inspira essa posição jurídica por ela ocupada" (Preclusão..., cit., p. 276).

346 Vide item "3.2" do Capítulo 3.

347 No entendimento de SERGIO JOSÉ BARBERIO, a parte terá não apenas que se encontrar em uma situação de dificuldade ou impossibilidade de produzir a prova, mas também a parte contrária deverá estar em melhores condições de produzir a prova contrária (a parte deve encontrar-se em uma posição “dominante” em relação à prova) (Cargas..., cit., p. 102 e 104). Embora haja uma ampliação na matéria submetida ao conhecimento do magistrado, o que para os críticos da técnica dinâmica atua como um elemento de ineficiência (atraso no trâmite processual), entendemos ser imprescindível a valoração da situação fática, sendo preferível ampliarmos os debates antes da fase probatória do que 
produzir provas, ${ }^{348}$ podendo chegar a duas conclusões distintas, com efeitos igualmente diferentes.

Na primeira hipótese, fica evidenciado que a parte não originalmente onerada se encontra em uma situação privilegiada ao seu adversário em relação à produção de provas, seja por aspectos profissionais, técnico-informacionais ou fáticos, ou seja, há uma desigualdade na capacidade das partes de fornecer o substrato da prova, e essa dificuldade de uma das partes fica contrastada com a maior facilidade da parte contrária, devendo ser sopesada pelo juiz mediante a redistribuição do ônus probatório, "reequilibrando" as forças das partes litigantes.

Por outro lado, a análise da situação da parte não inicialmente onerada pode demonstrar que a mesma dificuldade ou impossibilidade enfrentada pela parte originalmente onerada também se dá em relação ao seu adversário, vale dizer, a extrema dificuldade ou impossibilidade na produção de provas é de ambos, de modo que não há desigualdade na capacidade de produzir prova, devendo prevalecer a regra estática, geral e abstrata de distribuição do ônus probatório.

Essa constatação é relevante para restringir a aplicabilidade da técnica dinâmica apenas àqueles casos em que há uma real necessidade de intervenção do ente estatal para suprir desigualdades substanciais entre os litigantes, e não simplesmente para facilitar o êxito de uma das partes.

\section{Como leciona Jorge W. PEYRANO,}

[...] aquel desplazamiento del onus probandi será aceptable, sólo si, respecto de tales hechos, el demandado se encontrara, a su vez, en reales posibilidades de acreditarlos, pues en caso contrario, cundo las dificultades probatorias afecten tanto el actor cuanto al demandado, la inversión de la carga procesal respectiva ho halla justificativo alguno atento a que constituiría, también, un quebrantamiento a los multinombrados principios fundantes de la distribución del esfuerzo probatorio, pero en esta oportunidad, contra la factibilidad de éxito de la demandada. ${ }^{349}$

simplesmente ignorar a técnica de dinamização e não se chegar a um convencimento sobre a questão fática objeto da demanda e relevante para a solução da controvérsia. sentido contrário por essa parte e que tiverem o condão de transformar o ponto em uma questão controvertida, seja pela não ocorrência dos pressupostos fáticos das normas quem sustentam as pretensões da parte onerada (ROSENBERG) ou dos efeitos pretendidos pela parte contrária (MICHELLI) 
A visão moderna do processo tem como um dos escopos a entrega da tutela jurisdicional a quem efetivamente faz jus. Se uma das partes encontra dificuldade em fazer prova das suas alegações de fato, por se tratar de uma prova diabólica, não se pode simplesmente transferir a prova diabólica para a parte contrária, ${ }^{350}$ pois, ao assim agir, não se estaria buscando a igualdade substancial das partes, mas simplesmente pendendo a balança para um dos lados.

Nunca é demais lembrar que a distribuição do ônus probatório com base na técnica dinâmica está calcada na verificação in concreto da maior capacidade (profissional, técnico-informacional ou fática) da parte que não estava onerada em produzir prova em oposição à extrema dificuldade ou impossibilidade da parte abstratamente onerada, sempre com o objetivo de garantir a igualdade substancial e a adequada apuração dos fatos para obtenção de um julgamento mais justo e condizente com o direito material.

Essa "extrema dificuldade" ou "impossibilidade", contudo, deve ser qualificada, como veremos no próximo requisito.

\subsubsection{Inexistência da culpa da parte onerada pela extrema dificuldade ou impossibilidade de produzir prova}

Vimos no item precedente que a técnica de distribuição dinâmica do ônus probatório está condicionada a uma desigualdade na capacidade das partes de produzir prova, apurada pela extrema dificuldade ou impossibilidade da parte originalmente onerada e, por outro lado, a facilidade da parte contrária em provar o fato contrário.

No entanto, não basta a mera apuração da desigualdade, devendo o magistrado também se atentar para as causas (origem) dessa desigualdade, que não poderá estar amparada na conduta da própria parte onerada, sob pena de inaplicabilidade da técnica dinâmica. 
Com efeito, na hipótese de o magistrado apurar que foi a própria parte quem gerou o estado de extrema dificuldade ou impossibilidade na produção da prova que lhe incumbia, o que poderia se dar com a deliberada ocultação ou destruição da prova pela parte onerada, provavelmente porque essa fonte de prova não representava exatamente aquela alegação de fato sustentada em sua ação ou em sua defesa, ele não deve aplicar a distribuição dinâmica de ônus da prova, mantendo a regra geral e predeterminada, pois estaria beneficiando a parte por sua própria torpeza. ${ }^{351}$

Essa conduta do magistrado deve se repetir mesmo nas hipóteses em que, em decorrência da conduta da parte onerada, ficar constatada a desigualdade de capacidade entre as partes, ou seja, a maior facilidade da parte contrária de produzir provas, ${ }^{352}$ pois o magistrado não pode coadunar com a deslealdade e a má-fé da parte onerada.

Aliás, aqui seria até mesmo a hipótese de aplicação das penalidades decorrentes da litigância de má-fé à parte que tentar se valer da distribuição dinâmica do ônus da prova quando tenha sido essa mesma parte quem ocasionou a situação de extrema dificuldade ou impossibilidade de produzir a prova. ${ }^{353}$

De qualquer forma, se o magistrado, na apuração das circunstâncias que levaram ao estado de extrema dificuldade ou impossibilidade na produção da prova, verificar que tais fatos decorrem exclusivamente da parte onerada, não deverá deslocar o ônus probatório com base na técnica dinâmica, pois a extrema dificuldade ou impossibilidade na produção probatória deve decorrer de fatos alheios à vontade da parte onerada.

351 Trata-se da proibição do venire contra factum proprium, mais comumente estudada no direito civil, mas que tem plena aplicação também no âmbito processual. Como leciona ANTÓNIO MANUEL DA ROCHA E MENEZES CORDEIRO, o “"venire contra factum proprium' postula dois comportamentos da mesma pessoa, lícitos em si e diferidos no tempo. O primeiro - 'factum proprium' - é, porém, contrariado pelo segundo" (Da boa-fé no direito civil. 2. ed. Coimbra: Almedina, 2001. p. 745), que se verifica quando reunidos os seguintes requisitos: (i) o factum proprium; (ii) a legítima confiança; (iii) a contradição ao factum proprium; e (iv) a ocorrência de dano efetivo ou potencial.

352 Essa situação, em verdade, é de difícil ocorrência, uma vez que, se houver ocultação ou destruição da fonte de prova, a dificuldade em produzir a prova será de ambas as partes.

353 A litigância de má-fé restaria configurada por opor "resistência injustificada ao andamento do processo" e "proceder de modo temerário em qualquer incidente ou ato do processo", nos termos dos incisos IV e V do artigo 17 do Código de Processo Civil. 


\subsubsection{Verossimilhança das alegações de fato}

Embora a doutrina "clássica" sobre a técnica de distribuição dinâmica dos ônus probatórios não vislumbre a verossimilhança da alegação de fato como um requisito para a sua aplicabilidade, ${ }^{354}$ entendemos que deve ser mais um elemento condicionante a ser examinado pelo juiz no caso concreto.

O requisito da verossimilhança foi imaginado na doutrina pátria, pelo escólio de YoshIKAWA, ${ }^{355}$ fazendo um paralelo entre a distribuição dinâmica e a redistribuição do ônus da prova já consagrada no Código de Defesa do Consumidor, insculpida no inciso VIII do artigo $6^{\circ}$, de modo que a incidência da regra da distribuição dinâmica também ficaria sujeita à comprovação da verossimilhança da alegação de fato formulada pela parte originalmente onerada, incumbência que caberia, evidentemente, a esta parte para poder se desonerar da prova.

Em nosso sentir, a exigência do requisito na verossimilhança para aplicar a regra dinâmica é acertada.

Como expusemos anteriormente, embora sejamos defensores da aplicação da técnica dinâmica no direito pátrio, o seu uso descomedido pode gerar injustiças ainda mais graves que um julgamento pela regra estática de distribuição do ônus da prova.

Já antecipando em parte o que discorreremos no item " 5.8 " deste Capítulo, a técnica prevista no Código de Defesa do Consumidor é, para nós, exatamente a mesma técnica denominada de distribuição dinâmica do ônus da prova na Argentina, embora insculpida sob enfoques diversos, daí a necessidade de que em ambas as hipóteses (relações consumeristas e demais relações) se submetam aos mesmos requisitos.

De fato, enquanto o Código de Defesa do Consumidor foca a parte inicialmente onerada (o consumidor), que deixará de estar onerada quando suas alegações de fato forem

\footnotetext{
354 Em especial aquela desenvolvida na Argentina. Em alguns casos relatados na jurisprudência argentina os magistrados se valeram da regra da normalidade, mas não identificamos casos em que a verossimilhança da alegação de fato tenha sido exigida como requisito condicionante à aplicação da distribuição dinâmica do ônus da prova.

355 Considerações..., cit., p. 150-151. Embora para o aludido autor a "verossimilhança" necessária se equivalha aquela necessária para as medidas cautelares e a antecipação da tutela, equivalente a uma "probabilidade", como já tivemos a oportunidade de expor na nota 84.
} 
verossímeis e esta parte (o consumidor) se encontrar em um estado de hipossuficiência em relação do fornecedor, por outro lado, a teoria dinâmica prioriza a parte que irá receber o ônus probatório, por estar em melhores condições de produzir a prova.

Por uma questão de segurança (e coerência sistêmica), sobretudo por já existir uma dose de subjetividade no deslocamento do ônus probatório, a técnica dinâmica não pode nem ser aplicada indistintamente, ${ }^{356}$ em relação a toda e qualquer alegação fática em que a parte onerada esteja em situação de extrema dificuldade ou impossibilidade de produzir a respectiva prova, e a parte contrária tenha melhores condições de se desincumbir do ônus de provar.

Como medida de contenção ao uso desenfreado da técnica da distribuição dinâmica do ônus probatório, a exigência da demonstração da verossimilhança da alegação de fato, de cujo ônus a parte pretende se desonerar com a atribuição do ônus da prova à parte contrária, mostra-se uma importante aliada.

\subsubsection{Inviabilidade do uso de outros meios de flexibilização da distribuição do ônus da prova elou dos poderes instrutórios do juiz}

Ainda entre os requisitos intrínsecos à aplicação da distribuição dinâmica do ônus da prova devemos mencionar a constatação de inviabilidade prática do uso de outros meios de flexibilização da distribuição do ônus probatório e/ou dos poderes instrutórios do juiz.

Conforme já tivemos diversas oportunidades de mencionar ao longo do presente trabalho, a técnica dinâmica é marcada pela subsidiariedade e excepcionalidade, de maneira que, antes da sua efetiva aplicação, o juiz tem o dever de esgotar todos os outros meios que lhe estejam disponíveis para a facilitação da defesa das partes em juízo, como pela flexibilização de distribuição do ônus da prova, com o emprego das presunções e indícios, e para a apuração e esclarecimento dos fatos relevantes do processo, como os poderes instrutórios que possui. 356 Já vimos que a técnica dinâmica é subsidiária e excepcional (vide itens "5.2.2" e "5.2.3" do presente
Capítulo). 
Somente se tais medidas se mostrarem insuficientes (ou forem impertinentes no caso concreto), caberá ao juiz, desde que presentes todos os requisitos intrínsecos e extrínsecos examinados neste item "5.3", ordenar a redistribuição dos ônus probatórios com base na regra dinâmica.

A confrontação prática da técnica de dinamização com os meios alternativos de flexibilização de distribuição do ônus da prova e com os poderes instrutórios será detidamente examinada no Capítulo 6, a seguir, em que ficará evidenciado o real campo de incidência da regra dinâmica.

\subsubsection{Necessidade de decisão adequadamente fundamentada}

A transferência do ônus da prova de uma das partes para a outra com fundamento na técnica de distribuição dinâmica do ônus da prova opera-se ope judicis, ou seja, depende de uma manifestação expressa do juiz para que tenha aplicação. ${ }^{357}$

Essa manifestação judicial, assim como os demais atos decisórios proferidos no curso do processo pelo juiz, se dá por meio de uma decisão interlocutória, que deve estar devidamente fundamentada.

No entanto, essa fundamentação, diante da relevância que o acolhimento da regra dinâmica irá ocasionar, não pode se limitar a declarar presentes os requisitos, como comumente se verifica em outras decisões interlocutórias, não podendo, da mesma forma, valer-se da "concisão" prevista no artigo 165 do Código de Processo Civil. ${ }^{358}$

A exigência de fundamentação da manifestação judicial tem, ainda, amparo constitucional, previsto no inciso IX do artigo 93 da Magna Carta. Como ato de exceção,

357 Ainda que haja, no futuro, previsão expressa autorizando o uso da técnica de distribuição dinâmica do ônus probatório, a sua aplicação sempre dependerá da averiguação do caso concreto para apontar a presença ou não dos requisitos condicionantes, de modo que, ainda assim, a redistribuição dos ônus probatórios será ope judicis e não ope legis. O mesmo se dá em relação à regra do inciso VIII do artigo $6^{\circ}$ do Código de Defesa do Consumidor, embora ainda hoje haja corrente em sentido contrário, por exemplo, ANTONIO GIDI (Aspectos..., cit., p. 36).

358 O Projeto do novo Código de Processo Civil, em seu artigo 486, $\S 1 .^{\circ}$, estabelece os requisitos ou "elementos" mínimos a serem observados pelo magistrado para que qualquer decisão judicial seja considerada corretamente fundamentada. 
condicionado ao preenchimento dos requisitos intrínsecos e extrínsecos, o magistrado deve expor na decisão que exarar os motivos que justificam, in concreto, a redistribuição do ônus probatório entre as partes.

Além de justificar o uso de técnica excepcional, a correta fundamentação permitirá à parte agora onerada se valer dos meios recursais para impugnar a opção do magistrado pela técnica dinâmica, em vez da técnica geral e abstrata de distribuição do ônus probatório.

Questão interessante que surge a partir do requisito da fundamentação é se o magistrado teria realmente uma opção entre as técnicas estática e dinâmica, ou se sua manifestação é vinculada.

Temos para nós que o magistrado, na análise do caso concreto, apurando a ocorrência dos requisitos autorizadores do uso da técnica dinâmica, não está totalmente livre para escolher entre aplicá-la ou não aplicá-la. O magistrado tem um poder-dever de assegurar a igualdade substancial e buscar a formação da sua convicção com base na correta apuração dos fatos, de modo que, se a técnica dinâmica se mostra aplicável na espécie, ele deverá se valer dela para assegurar a tutela équa e justa.

Isso não significa, contudo, que sua decisão será totalmente vinculada. Por depender do exame das peculiaridades do caso concreto, em especial a constatação da desigualdade nas capacidades probatórias das partes, o magistrado detém uma margem de discricionariedade, que será fundamental para a verificação do preenchimento dos requisitos e condicionantes.

Entendemos, assim, que há um meio-termo entre a total discricionariedade e a total vinculação do juiz na aplicação da técnica dinâmica. Deve haver uma tolerância entre ambos, encontrando-se o primeiro mais presente na fase inicial da verificação do caso concreto e o segundo, na fase final de tomada de decisão.

Ainda relacionado ao tema da fundamentação, outro ponto de divergência é quanto à disponibilidade das partes em relação à aplicação da técnica de distribuição dinâmica do ônus da prova. O magistrado estaria limitado a se valer da técnica de dinamização apenas se suscitado por uma das partes ou ele poderia aplicá-la de ofício? 
A par dos seus poderes instrutórios, que reduzem o campo de incidência da técnica dinâmica como regra de estruturação da prova, entendemos que o princípio dispositivo das partes encontra-se amplamente mitigado também em relação à distribuição do ônus da prova, de forma que o magistrado poderia ordenar, de ofício, o deslocamento do ônus da prova sempre que entender que de tal maneira a desigualdade na capacidade probatória das partes será suprimida e a descoberta da verdade, potencializada.

O processo moderno se desprendeu das amarras do formalismo exacerbado e o juiz deixou de ser um elemento estático e passivo, motivo pelo qual não existe razão para querer condicionar a aplicação da técnica de distribuição dinâmica do ônus probatório à prévia alegação das partes, desde que, por certo, seja observado o contraditório, como exporemos no item seguinte.

Para concluir, em síntese, o magistrado pode e deve se valer da técnica da dinamização sempre que constatar, ainda que de ofício, a presença dos requisitos intrínsecos e extrínsecos de sua aplicabilidade, determinando o deslocamento do ônus probatório por meio de uma decisão fundamentada, sempre que não for possível se determinar com precisão a prova pendente de realização.

Com efeito, se a prova pendente de realização for de conhecimento do magistrado, ele poderá se valer dos seus poderes instrutórios e determinar a realização da prova, ou, ainda que assim não o faça, poderá alertar as partes sobre a necessidade dessa prova, para que as partes adotem as providências para sua produção. ${ }^{359}$

\subsubsection{Necessidade do efetivo contraditório}

O respeito ao contraditório, também alçado à garantia constitucional por força do inciso LV do artigo $5 .^{\circ}$ da Constituição Federal, é imprescindível para a validade da

359 Essa constatação revela, mais uma vez, o caráter subsidiário e excepcional da técnica de distribuição dinâmica do ônus da prova, a ser utilizada como ultima ratio na obtenção da prova e esclarecimento dos fatos. No item "5.10" e no Capítulo 6, quando fizermos a confrontação da técnica com os poderes instrutórios do juiz e com outros mecanismos de flexibilização e apuração dos fatos, essa assertiva restará mais uma vez evidenciada. 
decisão do magistrado que aplica a distribuição dinâmica do ônus da prova, e deve ser compreendido além do tradicional binômio "informação" e "possibilidade de reação". 360

O processo deve ser construído a partir de um constante diálogo entre partes e juiz, por meio do qual o juiz deve orientar as partes sobre as providências que estão sendo e serão adotadas, com a indicação dos respectivos ônus, faculdades, poderes e deveres das partes, e, por outro lado, ele deve oportunizar às partes se manifestarem previamente a todos os atos decisórios e de direcionamento do processo.

Em relação à aplicação da técnica de distribuição dinâmica dos ônus probatórios não poderia ser diferente, independentemente do momento em for aplicada.

Se adotarmos a técnica de dinamização como uma regra de procedimento, antes de proferir seu ato decisório (que pode ser de ofício, como vimos), seria prudente que o magistrado ouvisse as partes, inclusive, oportunizando-lhes a produção de prova sobre o atendimento ou não dos requisitos intrínsecos e extrínsecos, sob o risco de assim não o fazendo ofender o contraditório. ${ }^{361}$

Ainda que essa "dilação cognitiva" possa obstruir, por um instante, o curso "natural" do processo, não temos alternativa senão agir de tal modo antes de se passar para a fase probatória propriamente dita, pois só assim se terá a segurança necessária para aplicação de uma regra de exceção. ${ }^{362}$

Também após a tomada de decisão é imprescindível que a parte que se tornar onerada pela produção da prova possa "reagir", impugnando o ato decisório por meio de recurso competente, ${ }^{363}$ ou, "aceitando" o ônus, produzir a prova respectiva, como

360 Para CARLOS AlBerto ALVARO DE OlIVEIRA, essa concepção do princípio é "acanhada", "dominante no século XIX", de forma que somente se considerará atendido o princípio se propiciada às partes a participação real e efetiva na realização dos atos preparatórios da decisão judicial (Garantia do contraditório. In: CRUZ E TUCCI, José Rogério (Coord.). Garantias constitucionais do processo civil: homenagem aos 10 anos da Constituição Federal de 1988. São Paulo: RT, 1999. p. 135).

362 Celeridade não é sinônimo de efetividade!

363 O recurso, pelo Código de Processo Civil de 1973, é o Agravo, preferencialmente por instrumento, por se tratar de uma decisão geradora de riscos iminentes e de difícil reparação à parte onerada, como sustenta ARTUR CARPES (A nova relação do caput do art. 522 do CPC (Lei 11.187/2005) e o recurso cabível da decisão acerca da dinamização dos ônus probatórios. Revista de Processo. São Paulo: Revista dos Tribunais, v. 35, n. 179, p. 106-107, jan. 2010), embora não vejamos impedimento ao uso 
trataremos em maiores detalhes no item seguinte, de forma que o contraditório seja preservado.

Por outro lado, se a técnica da distribuição dinâmica do ônus da prova for adotada como técnica de julgamento e o deslocamento do ônus ocorrer apenas na sentença, com o que não concordamos, a validade dessa sentença também estará condicionada à observância do contraditório.

Mas como o contraditório se desenvolverá nessa hipótese?

Para PEYRANO esse contraditório é "implícito". ${ }^{364}$ As partes, ao iniciarem um litígio, já devem saber (ou ao menos deveriam) que a distribuição do ônus da prova possui uma regra geral e abstrata, predeterminada na norma, e uma regra excepcional de que o juiz pode se valer para transferir o ônus probatório de uma parte à outra.

Ainda de acordo com o autor argentino, para evitar qualquer risco do uso da técnica dinâmica, que somente seria aplicável em caso de dúvida do magistrado no momento de sentenciar (aspecto objetivo do ônus da prova), as partes deveriam produzir todas as provas que lhes cabiam, bem como aquelas que poderiam produzir para refutar as alegações de fato cujo ônus probatório era da parte contrária. Se assim não agissem, assumiriam o risco da dúvida e da dinamização da distribuição dos ônus probatórios, de modo que, se esta fosse pronunciada na sentença, não haveria que falar em "decisão surpresa" e/ou ofensa ao contraditório.

Em nosso entendimento, não seria possível admitir uma postura omissiva do juiz em relação à distribuição dos ônus probatórios durante todo o processo e apenas no momento da sentença ele se valer da técnica dinâmica para definir o vencedor da demanda. Essa hipótese fere flagrantemente o contraditório e produz sim uma "decisão surpresa". 365

do Agravo Retido. Pela sistemática aprovada no parecer final do projeto do novo Código de Processo Civil, contudo, a hipótese de cabimento do Agravo de Instrumento, que havia sido sugerida pela Câmara dos Deputados, foi suprimida, razão pela qual, se aprovado texto tal como se encontra atualmente, da decisão que acolher ou rejeitar a distribuição do ônus da prova com base na técnica dinâmica, não poderá ser atacada por recurso de Agravo de Instrumento.

364 La doctrina..., cit., p. 88-91.

365 EL CLARO, Roberto Benghi. Direção material do processo. 2009. Tese (Doutorado em Direito Processual) - Faculdade de Direito, Universidade de São Paulo, São Paulo. 
Inicialmente, porque o magistrado estaria tomando uma decisão de ofício, sem qualquer consulta prévia às partes, que não puderam expor suas afirmações para poder influenciar positiva ou negativamente, ou mesmo produzir prova sobre a situação autorizadora da dinamização dos ônus probatórios.

Como vimos, existem diversos requisitos e condicionantes para que a dinamização da distribuição do ônus da prova ocorra e as partes devem ter oportunidade para se manifestar e provar a existência ou inexistência desses requisitos e condicionantes.

Não bastasse isso, ainda que as partes conheçam a regra excepcional (que, quando muito, caberia aos respectivos advogados conhecer), seria totalmente contraproducente exigir das partes a realização de provas sobre todas as questões fáticas (ainda que o ônus não lhes incumbisse) apenas para que não corressem o risco de uma alteração futura e incerta dos respectivos ônus.

A regra de distribuição dos ônus probatórios tem como uma de suas finalidades a de organizar a fase instrutória do processo, atribuindo ônus distintos às partes. Sem essa regra, o processo correria sérios riscos de se tornar um “caos probatório”, quiçá infindável.

Portanto, para que a teoria dinâmica seja aplicada na sentença sem que haja ofensa ao contraditório, o que admitimos apenas para o exercício da reflexão, entendemos que o magistrado deveria, ao menos, fazer um alerta prévio às partes, ${ }^{366}$ antes da fase instrutória, de que poderá, eventualmente, utilizar-se da técnica de distribuição dinâmica do ônus da prova ao sentenciar e que as partes, caso não queiram correr o risco da dúvida e da assunção de ônus que não lhes incumbiam originalmente, deverão produzir todas as provas que entendam pertinentes e necessárias à formação da convicção do magistrado.

Ainda que se adote tal postura, que em nosso sentir apenas minimizaria os danos, entendemos impraticável a aplicação da técnica de distribuição dinâmica dos ônus probatórios apenas na sentença, como regra de julgamento, pois, de qualquer maneira, a parte não teria a faculdade de se desincumbir do ônus após o momento em que 
efetivamente se tornou onerado, o que, como veremos no próximo item, também é um requisito a autorizar a sua aplicação.

\subsubsection{Oportunidade para a parte se desonerar}

O último requisito que entendemos ser imprescindível à aplicabilidade da técnica de distribuição dinâmica dos ônus probatórios é a concessão de oportunidade para a parte que se tornou onerada produzir a prova que passou a lhe incumbir.

Como já vimos, o ônus é um imperativo do próprio interesse, que a parte tem a faculdade de cumprir ou não, e, optando-se por não cumprir, a parte onerada poderá sofrer os efeitos negativos cabíveis, que atuam em prejuízo apenas dessa parte.

É da essência do instituto "ônus" que a parte sempre tenha a opção entre fazer e não fazer, cumprir ou não cumprir o ônus que lhe foi imposto, conforme a sua livre escolha.

Nesse sentido, sempre que o juiz estiver diante de um caso de aplicabilidade da técnica de distribuição dinâmica dos ônus da prova, que acarretará o deslocamento do ônus de uma parte à outra, ${ }^{367}$ é imprescindível que a parte a quem for incumbido o ônus tenha a faculdade entre produzir a prova ou deixar de produzi-la.

Se não for dada essa faculdade à parte, por certo que não estaremos mais falando em "ônus", mas em "imposição" ou algo que o valha, na medida em que se retira da parte o elemento volitivo (probabilidade de fazer ou não fazer) e lhe decreta um fim único e imutável, qual seja a imposição dos efeitos negativos da não desincumbência do ônus, em um ato que beira o autoritarismo.

Ao adotarmos a possibilidade de a parte se desonerar a partir do momento em que o ônus lhe é imposto como um requisito para a aplicação da técnica de distribuição

367 Embora, como anteriormente exposto, a prova a ser produzida não seja a mesma, pois a parte onerada terá que provar que aquela questão de fato ocorreu conforme as suas alegações, e não conforme a alegação da parte contrária. 
dinâmica dos ônus probatórios, forçosamente temos que reconhecer a sua inaplicabilidade apenas no ato de sentenciar, como mera regra de julgamento.

E assim o fazemos porque consideramos ser uma flagrante ofensa ao contraditório, bem como um conflito inafastável chamar de "ônus" algo cujos efeitos são impostos à parte sem que ela possa exercer o elemento essencial do ônus, que é a opção entre se desincumbir ou não, sabendo que os efeitos da negativa apenas lhe atingirão.

Por certo que nosso posicionamento não exclui o aspecto objetivo do ônus da prova, e seria mesmo impossível fazê-lo, em face da impossibilidade do non liquet, mas apenas afasta a hipótese de aplicação da técnica da distribuição dinâmica dos ônus probatórios somente como uma regra de julgamento e reforça a tese de que se trata, efetivamente, de uma técnica de estruturação da prova para suprimir eventuais desigualdades das partes, potencialização da descoberta da verdade e, consequentemente, da efetividade processual.

\subsection{Momento da aplicação da distribuição dinâmica do ônus da prova}

Concluímos o item anterior com a ideia de que a técnica da distribuição dinâmica do ônus da prova é, essencialmente, uma regra de procedimento e não uma regra de julgamento, ${ }^{368}$ o que será essencial para a definição do momento em que a técnica é aplicável.

Como técnica de organização da prova, o magistrado deverá se ater à distribuição do ônus da prova em momento anterior à própria produção da prova e após a fixação dos pontos controvertidos.

De fato, é consequência lógica que a distribuição do ônus da prova ocorra antes da produção da prova, pois é nesse momento que as partes se desincumbirão ou não dos respectivos ônus. 
Da mesma forma, somente é possível se cogitar a distribuição de ônus probatório após a definição do que será objeto de prova (o thema probandum), afinal se determinada alegação de fato não necessitar de prova, igualmente não haverá ônus a ser distribuído (e desincumbido).

Assim, o momento ideal para o magistrado redefinir os respectivos ônus probatórios das partes, no procedimento ordinário, é na audiência preliminar do artigo 331 do Código de Processo Civil, ${ }^{369}$ após fixar os pontos controvertidos, e antes de determinar as provas a serem produzidas, podendo, inclusive, dar oportunidade às partes de redefinirem as provas que pretendem produzir após a redistribuição dos ônus probatórios com base na técnica de distribuição dinâmica do ônus da prova.

Não obstante a definição desse momento como o "ideal", não podemos esquecer que a técnica dinâmica caracteriza-se pela sua sintonia com a situação processual das partes, que está em constante mutação, o que equivale a dizer que após a prolação da decisão aplicando a dinamização, se a situação fática se modificar, o juiz poderá utilizar novamente a técnica dinâmica para ajustar os ônus probatórios das partes, desde que seja dada oportunidade à parte de se desincumbir do ônus assumido.

Para os defensores da aplicação da técnica de distribuição dinâmica dos ônus probatórios apenas como regra de julgamento (a par das críticas formuladas anteriormente), o momento adequado para sua incidência seria apenas a sentença se, e somente se, o juiz não tiver formado seu convencimento por falta ou insuficiência de provas.

Por certo, não haveria por que se cogitar da distribuição dinâmica dos ônus probatórios na fase instrutória, pois sua função seria apenas e exclusivamente evitar o non liquet.

Repita-se: a incoerência dessa corrente está exatamente em ignorar o aspecto subjetivo do ônus da prova, que se torna ainda mais relevante quando sabemos que a

369 Muitas vezes essa audiência é suprimida e o juiz apenas profere o chamado "despacho saneador". Nessa hipótese, é no "despacho saneador" que o juiz deverá decidir sobre a aplicação da teoria da distribuição dinâmica dos ônus da prova, ajustando os respectivos ônus probatórios das partes. 
aplicação da técnica dinâmica implica deslocamento de ônus, o que equivale a dizer que surge uma nova situação jurídica.

Com a criação de uma nova situação jurídica, gera-se um novo ônus probatório e a parte tem que ter a faculdade de se desincumbir. E isso somente será possível se essa nova situação for estabelecida antes da fase probatória, daí por que entendemos que deve prevalecer o entendimento de que o momento de aplicação da técnica de distribuição dinâmica dos ônus probatórios é antes da sentença, sempre dando a oportunidade para a parte se desincumbir do ônus que lhe foi imposto.

\subsection{Distribuição dinâmica do ônus da prova e adiantamento das despesas processuais}

Outro aspecto relevante a ser examinado para a aplicação da distribuição dinâmica do ônus da prova é o financeiro, pois a produção de determinadas provas pode demandar quantias elevadas, em especial as provas periciais, que podem exigir um ou mais peritos especialistas, além de outros custos com materiais e experimentos.

O cerne da questão é saber se com a redistribuição dinâmica dos ônus probatórios as despesas inerentes à prova também se deslocam para a parte que se tomou onerada.

Não obstante a existência de corrente em sentido contrário, como vimos no item "4.4.4" do Capítulo 4, supra, nos parece imprescindível que com a atribuição do ônus a determinada parte também lhe seja transferido o respectivo ônus de antecipar as despesas necessárias para a prova que pretende produzir para se desincumbir do ônus probatório.

Se assim não fosse, e as despesas continuassem sob o encargo da parte originalmente onerada, bastaria que essa parte se negasse a antecipar os recursos para que a prova se tornasse inviável e, assim, a parte onerada não conseguiria se desincumbir do seu ônus, o que é um verdadeiro contrassenso.

A situação aqui é exatamente a mesma exposta no referido item "4.4.4" do Capítulo 4, quando tratamos da hipótese de redistribuição do ônus da prova nas ações 
envolvendo relações de consumo, devendo prevalecer a regra geral estabelecida no artigo 19 do Código de Processo Civil, que atribui a cada parte o ônus da prover as despesas dos atos que requerem no processo, combinado com o artigo 33 do mesmo diploma legal, que trata especificamente da perícia, conferindo à parte interessada na prova o ônus de antecipar as respectivas despesas.

\subsection{Tentativa de se formular uma definição para a regra de aplicabilidade da técnica de distribuição dinâmica do ônus da prova}

Expostos os elementos caracterizadores da técnica de distribuição dinâmica do ônus da prova, seus requisitos condicionantes, e definido o momento de aplicação, podemos agora tentar estabelecer uma definição para essa técnica, de modo a sintetizar o pensamento até aqui desenvolvido, não sem antes trazermos as definições de doutrinadores que se debruçaram sobre o tema.

Em uma leitura apressada, seria possível sustentar que a técnica de distribuição dinâmica do ônus da prova teria sua origem nos ensinamentos desenvolvidos por JEREMY BENTHAM, ${ }^{370}$ que, como vimos no item "3.6" do Capítulo 3, sustentava que "a obrigação (sic, ônus) da prova deve impor-se, em cada caso, a aquela parte que pode realizá-la com menos inconvenientes, isto é, com menos dilações, vexações e gastos". ${ }^{371}$

O primeiro entrave a tal associação é o aspecto histórico, pois o mestre inglês viveu e escreveu entre os séculos XVIII e XIX, influenciado pelos pensamentos iluministas e liberais em voga na época, em que o direito processual ainda não era visto como uma ciência autônoma, e o direito de ação ainda se confundia com o próprio direito material

370 Esse entendimento é sustentado por MAXIMILIANO GARCÍA GRANDE (Cargas probatorias dinámicas: ni nuevas, ni argentinas, ni aplicables. Disponível em: <http://www.academiadederecho.org/ biblioteca/biblio_display_cont.cgi?wAccion=down\&wid_cont=2705\&wFile=Cargas_probatorias_din amicas_Maxim_G_Grande.pdf>. Acesso em: 29 nov. 2014. Posicinamento reiterado em outra obra, em que afirma que "la manifestación más antigua de la teoría data de 1823 y fue expuesta por el filósofo inglés Jeremías Bentham. [...] es um deber desmitificar el nacimiento de esta doctrina, debido a que erróneamente se cree que esta teoría surgió em um juzgado de província argentino, para terminar exportándose a Europa, transcendendo las fronteras jurídicas. [...] la teoría de las cargas probatorias no tuvo su aparición en el mundo jurídico en nuestro país, pero si ha sido aquí donde ha tenido su renacer" (Las cargas probatorias dinámicas: inaplicabilidad. Buenos Aires: Jurís, 2005.

371 "La obligación de la prueba debe en cada individual imponerse á aquella parte que puede practicarla con menos inconveniente, es decir, con menos dilaciones, vejaciones y gastos" (Tratado..., cit., t. 2, p. 113). 
violado. ${ }^{372}$ Já a técnica dinâmica "moderna" é influenciada pelos ideais de instrumentalidade e efetividade do processo.

Outra distinção relevante consiste na forma de aplicação das técnicas. Para BENTHAM, a "solidariedade" da produção probatória deveria ser a regra geral e abstrata aplicável a todo e qualquer processo, mas a definição de quem se encontra em melhores condições nem sempre é fácil de ser identificada. A técnica de distribuição dinâmica dos ônus probatórios, por outro lado, é excepcional e subsidiária, incidente apenas quando a regra geral e estática se mostrar ineficaz.

Portanto, resta patente que não é possível confundir o pensamento de JEREMY BENTHAM com a técnica de distribuição dinâmica ora exposta.

Realizada essa explanação inicial, passemos a algumas definições da técnica dinâmica extraídas da doutrina, antes de formularmos nosso próprio conceito.

Para PEYRANO, de forma sintetizada, a técnica das "cargas probatorias dinámicas", determina que "se incumbe la carga probatoria a quien - por las circunstancias del caso y sin que interese que se desempeñe como actora o demandada - se encuentre en mejores condiciones para producir la probanza respectiva". 373

Na visão de INÉS LÉPORI WHITE, “essa teoria sustenta que, mais além da posição de autor ou réu, em certos casos, o ônus da prova recai sobre ambas as partes, em especial sobre aquela que se encontra em melhores condições para produzi-la". ${ }^{374}$

Por seu turno, HÉctor E. LEGUISAMÓN leciona que

[...] a teoria (sic, técnica) das cargas probatórias dinâmicas - favor probationis está inclinada a colocar o ônus da prova à parte que está em melhor posição para fazer isso, ou possui ao seu alcance mais facilmente os meios para esclarecer os fatos, em virtude da sua situação, em princípio, de superioridade técnica em

372 O próprio BENTHAM fala que esse sistema de distribuição do ônus da prova valeria em um sistema de "justiça franca e simples de procedimento natural” (Tratado..., cit., t. 2, p. 113), mas que em um sistema técnico a identificação da parte onerada seria mais difícil.

373 Aspectos procesales de la responsabilidad profesional. In: MORELLO, Augusto Mario (Coord.). Las responsabilidades profesionales: Libro al Dr. Luis O. Andorno. La Plata: LEP, 1992. p. 263.

374 “[...] esta teoría sostiene que, más allá del carácter de actor o demandado, en determinados supuestos la carga de la prueba recae sobre ambas partes, en especial sobre aquella que se encuentra en mejores condiciones para producirla" (Cargas..., cit., p. 60; grifos do autor). 
relação à contraparte, devendo fazer contribuições resultantes das evidências e não se amparar em meras negativas, ou transferir o ônus da prova para a outra parte, invocando critérios absolutos ou rígidos. ${ }^{375}$

Também em IVANA MARÍA AIRASCA encontramos uma concepção para a técnica de distribuição dinâmica dos ônus da prova, para quem importa

[...] uma inversão do ônus da prova em todas as circunstâncias do caso, recaindo sobre quem está em melhores condições técnicas, profissionais ou fáticas de produzir provas para além da posição de autor ou réu no processo ou se trate de fatos constitutivos, modificativos, impeditivos ou extintivos, e pode mover-se do ator para o réu e vice-versa $[\ldots .]^{376}$

Nas conclusões da V Jornadas Bonaerenses de Derecho Civil, Comercial, Procesal e Informático, ocorrida na cidade de Junín, Argentina, em 1992, ficou estabelecido que a técnica de distribuição dinâmica do ônus da prova

[...] importa uma mudança do ônus da prova, segundo forem as circunstâncias do caso, em cujo mérito ela pode recair, por exemplo, na cabeça de quem está em melhores condições técnicas, profissionais ou fáticas para produzi-las, a par da posição de autor ou réu ou se tratar de fatos constitutivos, impeditivos, modificativos ou extintivos. ${ }^{377}$

Conjugando esses conceitos com as características anteriormente examinadas, entendemos que, de acordo com a técnica de distribuição dinâmica do ônus da prova, o juiz, na análise do caso concreto, constatando a inoperabilidade do aspecto subjetivo do ônus probatório, por impossibilidade ou extrema dificuldade da parte originalmente onerada em se desincumbir desse ônus, deverá, excepcionalmente, deixar de aplicar a regra predefinida e atribuir o ônus probatório à parte contrária, seja ela autor ou ré, desde que fique demonstrado que esta possui melhor capacidade profissional, técnico-informacional

375 “...] la teoría de las cargas probatorias dinámicas - favor probationis - se inclina por poner el peso de la prueba sobre la parte que está en mejores condiciones de hacerlo, o posee a su alcance con mayor facilidad los medios para el esclarecimiento de los hechos, en virtud de que su situación, en principio, es de superioridad técnica con respecto a la contraparte, debiendo realizar aportes probatorios consiguientes y no ampararse en una mera negativa, o transferir la responsabilidad de la prueba a la otra parte, invocando criterios absolutos o rígidos" [La necessária madurez de las cargas probatorias dinámicas. In: PEYRANO, Jorge Walter (Dir.); WHITE, Inés Lépori (Coord.). Cargas..., cit., p. 116].

376 " $[. .$.$] un desplazamiento del onus probandi según fueren las circunstancias del caso, recayendo en$ cabeza de quien está em mejores condiciones técnicas, profesionales o fáticas para producir las pruebas, más allá del emplazamiento como actor o demandado en el proceso o de que se trate de hechos constitutivos, modificativos, impeditivoso, extintivos, y puede desplazarse del actor al demandado y viceversa" [Reflexiones sobre la doctrina de las cargas probatorias dinámicas. In: PEYRANO, Jorge Walter (Dir.); WHITE, Inés Lépori (Coord.). Cargas..., cit., p. 136].

377 “[...] importa un desplazamiento del onus probandi, según fueran las circunstancias del caso, en cuyo mérito aquél puede recaer, verbigracia, en cabeza de quien esté en mejores condiciones técnicas, profesionales o fácticas para producirlas, más allá del emplazamiento como actor o demandado o de tratarse de hechos constitutivos, impeditivos, modificativos o extintivos" (WHITE, Inés Lépori. Cargas..., cit., p. 61). 
ou fática para produzir a prova, não obstante se tratar de alegação de fato constitutivo, extintivo, impeditivo ou modificativo do direito do autor ou do réu.

Da referida definição podemos sintetizar a técnica de distribuição dinâmica dos ônus da prova como a transposição de um dever geral de colaboração na instrução probatória para a imposição de um ônus de produção probatória, com todos os riscos inerentes a sua não desincumbência, que se mostra aplicável como uma técnica para assegurar a igualdade substancial das partes e, tanto quanto possível, potencializar a descoberta da verdade, em consonância com os ideais de justiça, pacificação social e efetividade da tutela jurisdicional.

\section{Aplicabilidade da técnica da distribuição dinâmica do ônus da prova à luz do Código de Processo Civil de 1973}

$\mathrm{O}$ ordenamento pátrio vigente não possuiu norma expressa acolhendo a aplicabilidade da técnica de distribuição dinâmica do ônus da prova, ressalvada nas relações de consumo que, como já adiantamos e deixaremos mais evidente no item "5.9", adiante, embora comumente chamada de "inversão" do ônus da prova, nada mais é senão a técnica dinâmica enfocada sob o prisma da parte inicialmente onerada (consumidor) e que, em virtude da sua "hipossuficiência" para produzir a prova e a "verossimilhança" de suas alegações, deixará de estar onerada, transferindo o ônus da prova para o fornecedor.

Não obstante a falta de uma norma geral, aplicável a qualquer tipo de litígio submetido ao Poder Judiciário, a jurisprudência vem gradativamente acolhendo a aplicação da técnica de distribuição dinâmica dos ônus probatórios, e a doutrina também defende a sua aplicabilidade a partir de uma interpretação sistemática dos direitos e garantias constitucionais aplicáveis ao processo civil. ${ }^{378}$

378 Nesse sentido, DANILO KNIJNIK, ao se indagar se "seria legítima, no direito brasileiro, a teoria do ônus dinâmico?", responde afirmativamente, “a começar pela circunstância de que o direito brasileiro, de há muito reconhece ao juiz iniciativas probatórias para garantir a igualdade substancial entre os litigantes, não havendo porque essa mesma igualdade não se refletir no plano do ônus probatório" [As (perigosíssimas)..., cit., p. 947]. Também ANTONIO JANYR DALL'AGNOL JUNIOR (Distribuição dinâmica..., cit., p. 100-107), ARTUR CARPES (Ônus dinâmico..., cit., p. 123-132), SUZANA SANTI CREMASCO (A distribuição..., p. 94-111), e tantos outros entre os autores anteriormente citados. Para EDUARDO CAMBI, “a inversão do ônus da prova, como forma de proteção do direito material, pela técnica da teoria da distribuição dinâmica do ônus da prova, encontra respaldo imediato na dimensão 
A primeira dessas garantias é a do acesso ao Poder Judiciário, mas não apenas o acesso do ponto de vista formal, de "estar em juízo", mas de poder obter do órgão jurisdicional uma resposta ajustada à sua pretensão ou à sua defesa, o que, para se tornar possível, necessita passar obrigatoriamente pelo conhecimento dos fatos pelo magistrado, o que, por sua vez, somente será possível mediante o acesso às fontes e aos meios de prova. $^{379}$

Ocorre que, em determinadas circunstâncias, a parte pode estar impossibilitada ou com uma dificuldade excessiva em obter, atingir ou produzir a prova necessária à comprovação da sua pretensão, e a regra geral e abstrata impõe exclusivamente a essa parte o ônus da prova. Se ficarmos presos a essa regra estática, em última análise, estar-se-á negando a essa parte o acesso à Justiça, pois sem acesso às fontes e aos meios de prova dificilmente terá chances de ver o seu direito tutelado.

A ideia central do processo équo e justo é a concessão de uma tutela jurisdicional condizente com o pleito inicial do autor ou com as justificativas à sua resistência apresentadas pelo réu, por meio de um procedimento em que seja assegurada às partes a paridade substancial e o efetivo contraditório.

Sempre que for constatado um desequilíbrio entre as partes, capaz de ensejar resultados danosos à parte mais fraca unicamente por tal condição, o magistrado deve estar dotado de poderes para restabelecer a isonomia, conforme amparado na Constituição Federal, que por diversas oportunidades se refere à garantia da igualdade.

Da mesma forma, o inciso I do artigo 125 do Código de Processo Civil determina que o juiz deve dirigir o processo de modo a " assegurar às partes igualdade de tratamento", o que confirma a possibilidade (e porque não a necessidade) de uma intervenção do magistrado sempre que o desequilíbrio entre os litigantes puder influir negativamente para o resultado do processo, postura esta que pode se dar de diversas

objetiva do direito fundamental à tutela jurisdicional adequada e efetiva $\left(\mathrm{CF}\right.$, art. $5^{\circ}$, inc. XXXV)" (Curso de direito probatório. Curitiba: Juruá, 2014. p. 227 e 229; grifos do autor).

379 Daí falar em um "direito fundamental à prova", consistente na efetiva possibilidade de formular suas alegações e seus pedidos, participar ativamente da instrução probatória e de opinar sobre o resultado da investigação probatória. 
maneiras, entre elas pela redistribuição do ônus probatório, com a aplicação da técnica de distribuição dinâmica dos ônus da prova.

O artigo 130 do Código de Processo Civil, por seu turno, além de conferir poderes instrutórios para o magistrado ordenar, de ofício, determinadas provas, também o autoriza a estabelecer a produção das "provas necessárias à instrução do processo" pelas partes, o que se dá, efetivamente, pelo deslocamento do ônus probatório.

Ao ordenar que determinada parte produza certa prova (aspecto subjetivo do ônus da prova) que, em princípio, pela regra abstrata não lhe incumbia, automaticamente o magistrado está impondo a esta parte o ônus pela sua eventual não realização ou pela insuficiência dessa prova (aspecto objetivo do ônus da prova).

Ademais, o artigo 339 do Código de Processo Civil, ao consagrar o dever de colaboração "para a descoberta da verdade", impõe às partes uma conduta ativa a ambas, além de todos os terceiros que possam contribuir para a instrução probatória, e em relação às partes o juiz tem a possibilidade de utilizar da técnica da distribuição dinâmica do ônus da prova como um real motivador das partes em colaborar.

Ainda em decorrência dessa interpretação sistemática do Código de Processo Civil, o artigo 332 legitima a prova da verdade por todos os meios legais, bem como os moralmente legítimos. Se entendermos que os "meios" a que se refere o indigitado artigo não são apenas os "meios de prova", ${ }^{380}$ mas como sinônimo de "mecanismos" ou "técnicas", também é possível inferir que o legislador outorgou ao magistrado amplos poderes para se valer de outros instrumentos na descoberta dos fatos relevantes para o julgamento, entre eles a técnica da distribuição dinâmica dos ônus da prova.

Corroborando o aqui exposto, a técnica da "exibição de documento ou coisa", prevista nos artigos 355 a 363 do Código de Processo Civil, a ser examinada quando tratarmos dos mecanismos de flexibilização do ônus da prova no Capítulo 6, é um ótimo

380 Os meios de prova são mecanismos pelos quais as partes e o juiz fazem a comprovação das alegações de fato controvertidas, podendo ser documental, testemunhal (pessoal) ou pericial. A técnica de distribuição dinâmica do ônus probatório, por certo, não é um "meio de prova", mas uma técnica de atribuição dos respectivos ônus, com atuação subsidiária à regra legal insculpida no artigo 333 do Código de Processo Civil. 
exemplo de como a parte pode se tornar onerada pela produção de determinada prova sem que este ônus lhe incumbisse originalmente pela regra geral e abstrata do artigo 333 do Código de Processo Civil, pelo simples fato de estar na posse de documentos ou coisas que podem elucidar os fatos controvertidos mais facilmente. ${ }^{381}$

Não podemos deixar de lembrar, igualmente, o dever de lealdade processual previsto no artigo 14 do Código de Processo Civil, examinado no item "5.1.3" deste Capítulo, que impõe às partes uma conduta condizente com a verdade, confirmando o escopo do processo civil moderno de se atingir a pacificação social e não fomentar a lide e o "jogo" entre as partes. ${ }^{382}$

Aquele que age em desconformidade com a lisura e a honestidade, suprimindo ardilosamente do conhecimento do magistrado a verdade dos fatos relevantes ao deslinde da controvérsia em total desobediência ao dever de cooperação, pode (e deve) ser punido por litigância de má-fé, nos termos do artigo 17, incisos II, IV e V, combinados com o artigo 18, todos do Código de Processo Civil.

Por fim, não podemos deixar de lembrar a regra prevista no inciso II do paragrafo único do artigo 333, que veda a redistribuição do ônus da prova por convenção entre as partes quando "tornar excessivamente difícil a uma parte o exercício do direito".

Ou seja, salvo em tais casos, que equivalem à vedação da prova diabólica inversa da técnica de distribuição dinâmica dos ônus da prova, em relação aos direitos disponíveis, as partes têm total liberdade para estabelecer a distribuição do ônus probatório como bem lhes convier.

381 A técnica da exibição de documento ou coisa difere, contudo, da técnica de dinamização da distribuição do ônus da prova porque naquela a "melhor condição de produzir a prova" refere-se à prova da alegação de fato da parte contrária, e nesta se dá em relação à alegação de fato formulada pela própria parte que se tornará onerada.

382

Como já nos referimos anteriormente, foi PIERO CALAMANDREI quem primeiro definiu o processo como um "jogo", mas o próprio autor italiano adverte para a necessidade de observância do dever de lealdade, sob pena de configuração de má-fé e abuso do processo (Il processo come giuoco. Studi..., cit., v. 6, p. 51-53). Opondo-se a essa metáfora, BEDAQUE sustenta que "o processo não é jogo, em que o mais capaz sai vencedor, mas instrumento de justiça com a qual se pretende encontrar o verdadeiro titular de um direito. Não se pode aceitar que, em razão da hipossuficiência de um dos litigantes, chegue-se a uma decisão injusta, que não corresponda à realidade fática submetida a julgamento" (Poderes..., cit., p. 109). 
Se existe essa liberdade em relação às partes, ao magistrado, em sua busca pela verdade no trâmite processual, também deve ser assegurado flexibilizar a regra de distribuição e atribuir o ônus probatório de forma que melhor aproveite ao processo a participação das partes puder trazer.

O princípio dispositivo em matéria probatória, como já tivemos oportunidade de discorrer, é atualmente mitigado por um interesse "social" e "público" de se alcançar uma tutela jurisdicional condizente com a realidade fática, ou o mais próximo dela possível.

Dessa forma, a disponibilidade das partes pode ser suprimida por uma decisão judicial que apure, à luz do caso concreto, a dificuldade de uma parte "exercitar o seu direito" em face da impossibilidade ou excessiva dificuldade de esta parte instruir o arcabouço probatório de maneira suficiente a formar o convencimento do magistrado e, de outro lado, a efetiva capacidade/facilidade da parte contrária de trazer elementos probatórios que sustentem a sua versão da controvérsia fática previamente instaurada a partir de uma alegação de fato formulada por aquela primeira parte, a quem, pela regra geral e abstrata, caberia o ônus da respectiva prova.

Poderíamos, ainda, agregar à tese ora sustentada os princípios e garantias da dignidade da pessoa e da adaptabilidade do processo (instrumentalidade) para reforçar a aplicabilidade da técnica de distribuição dinâmica dos ônus da prova, uma vez que todos coadunam para que o processo sirva à obtenção da tutela jurisdicional por aquela parte que realmente teve o seu direito violado ou ameaçado ou aquela que demonstrar a inexistência de violação ou ameaça a qualquer direito da parte contrária, mas nunca por aquela parte que se mostrou mais perspicaz no manejo do instrumento processual.

Enfim, diante dos pressupostos axiológicos expostos no início do presente capítulo e da interpretação do sistema processual amparado na Constituição Federal, parece-nos evidente que o uso da técnica de dinamização da distribuição do ônus da prova deve ser reconhecido como aplicável no direito vigente, ainda que desprovido de uma norma legal que a preveja expressamente (à exceção das ações envolvendo relação de consumo), pois se trata de um mecanismo em perfeita consonância com os valores da segurança e da efetividade, que manejam toda a atividade jurisdicional. 


\section{8 \\ Inclusão da técnica da distribuição dinâmica do ônus da prova no projeto do novo Código de Processo Civil}

A par da previsão contida no inciso VIII do artigo 6. ${ }^{\circ}$ do Código de Defesa do Consumidor, o legislador pátrio concebeu a introdução da técnica de distribuição dinâmica dos ônus probatórios em pelo menos duas oportunidades anteriores, ${ }^{383}$ mas nenhuma delas prosperou.

A nova investida para tornar a regra dinâmica norma expressa se deu no Projeto de Lei n. ${ }^{\text {1 }}$ 166/2010 do Senado Federal, o qual foi objeto de substitutivo aprovado na Câmara dos Deputados, cujo artigo 370, na redação do parecer final apresentado em 27.11.2014 e aprovado em 04.12.2014, ${ }^{384}$ possui o seguinte conteúdo:
Art. 370. O ônus da prova incumbe:
I - ao autor, quanto ao fato constitutivo do seu direito;
II - ao réu, quanto à existência de fato impeditivo, modificativo ou extintivo do direito do autor.
$\S 10^{\circ}$ Nos casos previstos em lei ou diante de peculiaridades da causa, relacionadas à impossibilidade ou à excessiva dificuldade de cumprir o encargo nos termos do caput ou à maior facilidade de obtenção da prova do fato contrário, poderá o juiz atribuir o ônus da prova de modo diverso, desde que o faça por decisão fundamentada. Neste caso, o juiz deverá dar à parte a oportunidade de se desincumbir do ônus que lhe foi atribuído.
$\S 2 .^{\circ}$ A decisão prevista no $\S 10^{\circ}$ deste artigo não pode gerar situação em que a desincumbência do encargo pela parte seja impossível ou excessivamente difícil. $\S 3 .^{\circ}$ A distribuição diversa do ônus da prova também pode ocorrer por convenção das partes, salvo quando:
I - recair sobre direito indisponível da parte;
II - tornar excessivamente difícil a uma parte o exercício do direito.
$\S 4 .^{\circ}$ A convenção de que trata o $\S 3 .^{\circ}$ pode ser celebrada antes ou durante o processo.

O texto atual corrige algumas imperfeições da proposta original e do próprio Código de Defesa do Consumidor, deixando mais claras as características da técnica de distribuição dinâmica dos ônus probatórios, bem como a necessidade de preenchimento dos requisitos intrínsecos e extrínsecos (embora o texto projetado não relacione todos os requisitos anteriormente examinados).

Com efeito, o início do $\S 1 .^{\circ}$ do referido artigo 370 consagra o aspecto subsidiário e excepcional do uso da técnica dinâmica, apurada em “casos previstos em lei

383 Falamos do Anteprojeto de Código Brasileiro de Processos Coletivos e do Projeto de Lei n. 3.015/2008.

384 Disponível em: <http://www.senado.gov.br/atividade/materia/getPDF.asp?t=157884\&tp=1>. Acesso em: 10 dez. 2014. 
ou diante de peculiaridades da causa", ou seja, à luz do caso concreto deverá ser verificada a inaplicabilidade da regra geral e abstrata prevista no caput do mencionado artigo 370 (primeiro requisito), que, não obstante as críticas já formuladas, continua utilizando a posição das partes e a natureza dos fatos como critérios de distribuição do ônus da prova.

$\mathrm{O}$ mesmo $\S 1 .^{\circ}$ ainda expõe o segundo requisito intrínseco à aplicabilidade da técnica de distribuição dinâmica dos ônus probatórios, consistente na "impossibilidade ou a excessiva dificuldade (da parte) de cumprir o encargo nos termos do caput ou à maior faculdade de obtenção da prova do fato contrário", o que equivale a dizer que o magistrado deverá fazer a verificação da desigualdade substancial das partes quanto à capacidade de produzir prova, seja da alegação de fato da parte onerada, seja da alegação de fato contrária àquela formulada pela parte contrária.

A conjunção "ou" empregada no projeto para distinguir as capacidades das partes não deve ser interpretada como alternatividade, pois, como vimos, não basta apenas a parte inicialmente onerada estar em estado de dificuldade ou impossibilidade de produzir a prova. De outro lado, a parte que receberá o ônus da prova deverá estar em melhores condições de produzir a prova da sua alegação de fato contrária. Os requisitos são, portanto, cumulativos, e seria melhor que tivesse sido utilizada a conjunção "e", em vez de "ou".

A redação do $\S 2 .^{\circ}$ do artigo 370 projetado reforça a tese de cumulatividade dos requisitos ao prever a vedação à prova diabólica inversa. Como é cediço, a dinamização "não pode gerar situação em que a desincumbência do encargo pela parte seja impossível ou excessivamente difícil”".

Dentre os requisitos intrínsecos, apenas a verossimilhança, a inexistência de culpa da parte onerada e a inaplicabilidade de outros meios de flexibilização e/ou dos poderes instrutórios do juiz não estão previstos na atual redação do projeto, o que, em nosso sentir, pode contribuir para a aplicação por vezes equivocada da técnica de distribuição dinâmica dos ônus probatórios, calcada em alegações de fato desprovidas de qualquer amparo, de modo a impor o ônus da prova à parte contrária, que nem sempre conseguirá se desincumbir, exatamente porque a alegação de fato feita pela parte inicialmente onerada não tem qualquer embasamento. 
Quanto ao requisito da inexistência de culpa pela dificuldade ou impossibilidade também seria importante que estivesse expresso no texto projetado, para evitar atos maliciosos de criação artificial de tais situações, apenas com o intuito de transferir à parte contrária o ônus probatório.

Também não seria demais prever que o emprego da técnica dinâmica é subsidiário aos poderes instrutórios do juiz e aos demais meios de flexibilização da distribuição dos ônus probatórios, mas isso é possível de se extrair a partir de uma interpretação sistemática do projeto do novo Código de Processo Civil, que reforça os poderes instrutórios do juiz, como se depreende da leitura, por exemplo, dos artigos 8. ${ }^{\circ}$, 139, 367, 382, 418 e 435, bem como mantém as situações de aplicação das presunções, como nos artigos 305 e $371 .^{385}$

Em relação aos requisitos extrínsecos, andou bem o legislador pátrio ao prevêlos expressamente na norma projetada, ao menos em relação à necessidade de fundamentação da decisão que acolher a dinamização do ônus da prova (" $\$ 1 .^{\circ}[\ldots]$ poderá o juiz atribuir o ônus da prova de modo diverso, desde que o faça por decisão fundamentada") e quanto a necessidade de se oportunizar à parte onerada se desincumbir mediante a efetiva produção da prova (" $1 .^{\circ}[\ldots]$ o juiz deverá dar à parte a oportunidade de se desincumbir do ônus que lhe foi atribuído").

Com essas previsões, elimina-se qualquer questionamento que ainda poderia existir quanto ao momento em que a técnica dinâmica deve ser aplicada, restando impraticável de ocorrer na sentença, pois então inexistiria a possibilidade de desincumbência.

O momento de aplicação, embora não esteja explícito na norma em comento, deverá ser preferencialmente antes do início da fase instrutória, mas não vislumbramos qualquer impedimento de no seu curso o magistrado verificar a situação autorizadora do deslocamento do ônus, desde que sempre a parte a quem o ônus for atribuído tenha a faculdade de se desincumbir. ${ }^{386}$

385 Disponível em: <http://www.senado.gov.br/atividade/materia/getPDF.asp?t=157884\&tp=1>. Acesso em: 10 dez. 2014.

386 Também pode ocorrer de no curso da instrução, com o ônus já deslocado por prévia decisão do juiz, a parte que se tornou onerada demonstrar extrema dificuldade ou impossibilidade de produzir a prova e, 
Por outro lado, embora o aludido artigo 370 não mencione expressamente o requisito do contraditório, ele está previsto de forma genérica no artigo $7 .^{\circ}$ do texto projetado como uma garantia às partes, que deverão ser tratadas com paridade no curso do processo, de forma que não vislumbramos qualquer prejuízo pela omissão legislativa ao tratar da técnica de distribuição dinâmica dos ônus probatórios.

O artigo 10 do Código projetado reforça a necessidade do contraditório prévio à aplicação da técnica dinâmica, ao dispor que:

Art. 10. O juiz não pode decidir, em grau algum de jurisdição, com base em fundamento a respeito do qual não se tenha dado às partes oportunidade de se manifestar, ainda que se trate de matéria sobre a qual deva decidir de ofício.

A dúvida que ainda persiste é sobre a possibilidade de deslocamento do ônus da prova com base na técnica dinâmica de ofício pelo magistrado. O texto do projeto é omisso, mas, como já sustentamos, não vemos qualquer impedimento ao magistrado de assim agir, se constatar a presença dos requisitos intrínsecos e extrínsecos. ${ }^{387}$

Por fim, uma crítica que pode ser feita ao projeto é a supressão, na redação final aprovada no Senado Federal, ${ }^{388}$ da hipótese de cabimento do recurso de Agravo de Instrumento contra a decisão interlocutória que acolhe ou rejeita a aplicação da distribuição dinâmica dos ônus probatórios, em especial quando ocorrer depois da "decisão de saneamento e de organização do processo" do artigo $354 .{ }^{389}$

ao revés, a parte inicialmente onerada passar a ter melhores condições de produzir a prova de sua alegação, podendo o magistrado reatribuir o ônus da prova a esta parte, retornando ao status quo ante, sempre oportunizando à parte onerada da produção da respectiva prova. distribuição dinâmica é na "decisão de saneamento e de organização do processo", prevista no artigo 354 do texto projetado, oportunidade em que o magistrado poderá, de ofício, determinar a incidência da regra de dinamização. Oportuno ressaltar, contudo, que a verificação dos requisitos condicionantes à sua aplicação pode ocorrer durante a instrução probatória ou mesmo depois de encerradas as provas que haviam sido determinadas, o que não impedirá o julgador de decidir pela aplicação da técnica, ordenando a realização da respectiva prova pela parte que se tornou onerada. Disponível em: <http://www.senado.gov.br/atividade/materia/getPDF.asp?t=157884\&tp=1>. Acesso em: 10 dez. 2014.

389 Importante ressaltar que, em relação à "decisão de saneamento e de organização do processo", o projeto deixa claro que se trata de decisão não passível de recurso por meio de Agravo de Instrumento, permitindo às partes apenas, no prazo de cinco dias, "pedir esclarecimentos ou solicitar ajustes, [...] findo o qual a decisão se torna estável", conforme preconiza o $§ 1 .^{\circ}$ do artigo 354. 
No Substitutivo da Câmara dos Deputados ao Projeto de Lei do Senado n. ${ }^{\circ}$ 166/2010 havia sido inserido o inciso XIV ao artigo 1028, que trazia o rol das hipóteses de cabimento do Agravo de Instrumento, mas a redação final apresentada pelo Senado Federal em 27.11.2014 suprimiu essa hipótese, sob o argumento de que o projeto do novo Código de Processo Civil "segue o caminho da simplificação recursal e do desestímulo ao destaque de questões incidentais para discussões em vias recursais antes da sentença", de modo que a recorribilidade das interlocutórias "ficou restrita a situações que, realmente, não podem aguardar rediscussão futura em eventual recurso de apelação", uma vez que o projeto "flexibilizou o regime de preclusão quanto às decisões interlocutórias para permitir, se necessário for, a sua impugnação em futuro recurso posterior a sentença". 390

Em nosso sentir, o não acolhimento da sugestão da Câmara dos Deputados, para permitir o Agravo de Instrumento contra a decisão que aplicar ou rejeitar a distribuição dinâmica dos ônus probatórios, é prejudicial ao sistema, por criar uma situação de instabilidade, sobretudo quando a sentença for calcada na regra de distribuição do ônus da prova. ${ }^{391}$

Outrossim, a manutenção da sistemática sem a possibilidade do recurso de Agravo de Instrumento ofende os princípios da economia processual e da celeridade, uma vez que exigirá das partes o desenvolvimento de toda a instrução probatória, com dispêndio de tempo e dinheiro, para evitar uma sentença desfavorável, ao passo que, se determinada a correta distribuição dos ônus probatórios entre as partes, algumas provas poderiam ser dispensadas.

390 O artigo que trata do Agravo de Instrumento, da redação final do Projeto do novo Código de Processo Civil, é o 1012, restrito a 11 hipóteses.

391 Imaginemos uma situação em que o magistrado, na "decisão de saneamento e de organização do processo", decida, de ofício, pela aplicação da dinamização, atribuindo ao autor a prova de determinada alegação de fato, que pela regra estática caberia ao réu provar. $\mathrm{O}$ autor não consegue produzir provar capaz de elidir a alegação de fato formulada pelo réu, e este, por estar desonerado, não produz qualquer prova para comprovação da sua alegação. Diante do estado de dúvida, o magistrado julga favoravelmente ao réu, pois o ônus da prova, de acordo com a distribuição realizada no curso do processo a ele incumbia. Em Recurso de Apelação, o autor alega e demonstra que a aplicação da técnica de distribuição dinâmica não seria aplicável na espécie. O acolhimento do Recurso do autor não poderá ensejar uma simples inversão do resultado do processo, pois, se assim agisse, o Tribunal estaria ofendendo o direito de defesa do réu, que simplesmente deixou de produzir prova porque não estava mais onerado. A solução, em nosso sentir, seria a anulação da sentença, com o retorno do processo ao juízo de origem, para oportunizar ao réu, agora onerado, a produção da prova de sua alegação. Evidentemente, essa situação poderia ser evitada se da decisão que aplicasse a regra dinâmica fosse cabível Agravo de Instrumento, corrigindo-se, de imediato, eventual equívoco do juiz. 


\subsection{Comparação entre as técnicas de distribuição dinâmica do ônus da prova e de redistribuição judicial do ônus da prova prevista no Código de Defesa do Consumidor}

A conjugação do exposto no Capítulo 4 sobre a redistribuição do ônus da prova com o que apresentamos até aqui sobre a técnica de distribuição dinâmica dos ônus probatórios nos permite traçar, agora, um paralelo entre essas duas técnicas de organização da instrução probatória, haja vista que, bem compreendidas, constatamos que correspondem ao mesmo fenômeno, porquanto possuem uma justificativa fundamental e funcionalidade comuns, não obstante certas nuances nas redações das normas que as regulam, podendo ser identificadas como duas visões sobre o mesmo instrumento.

Como já relatamos ao longo do presente trabalho, o processo civil moderno, intimamente relacionado com os princípios e garantias fundamentais do homem, possui uma preocupação permanente com a verdade, sopesando segurança e efetividade, para que seja possível alcançar uma tutela jurisdicional équa e justa.

Nesse contexto, a participação e a cooperação das partes litigantes são fundamentais para legitimar o poder estatal que irá determinar a solução do conflito com base na apuração dos fatos que envolvem a demanda. Essa participação, contudo, não será plena se, no curso do processo, determinada parte encontrar obstáculos sobrenaturais à comprovação de sua pretensão, decorrente da sua total ou parcial incapacidade probatória, o que poderia lhe impedir por completo o acesso à justiça, e, em contrapartida, seu adversário aparenta ter plenas condições de provar suas alegações de fato, ainda que tal ônus não lhe incumba originalmente.

Para suprimir essa desigualdade material entre as partes, e dar o efetivo sentido à justiça no caso concreto, o juiz pode (rectius, deve) dar tratamento desigual aos desiguais, aplicando determinadas técnicas de flexibilização do ônus da prova, sempre com o intuito de se obter o melhor esclarecimento dos fatos possível e a aproximação da percepção à realidade, de modo que possa melhor julgar, atingindo os escopos do processo.

O que verificamos em relação às técnicas de redistribuição do Código de Defesa do Consumidor e de dinamização no Código de Processo Civil projetado é 
exatamente que ambos são mecanismos que visam readequar as cargas probatórias das partes litigantes, que por determinadas circunstâncias não se encontram em um estado de equilíbrio, como projeta o processo ideal.

Diante da constatação da desigualdade na capacidade probatória das partes, o juiz desloca determinada carga probatória da parte que se encontra em uma situação menos privilegiada em relação à prova de determinada alegação de fato para a parte que se apresenta como a mais capacitada para produzir a prova da alegação de fato por ela formulada para sustentar o resultado contrário da alegação de fato da parte onerada.

A essência da técnica, portanto, é precisa e exatamente a mesma na chamada “inversão" e na dinamização, inexistindo motivos para se atribuírem dois nomes para o mesmo instrumento, razão pela qual propomos, e assim o faremos no restante desta dissertação, a sempre nos referirmos à técnica como distribuição dinâmica do ônus da prova, seja para tratar das hipóteses que envolvem demandas decorrentes de relações consumeristas, seja para as ações envolvendo os mais diferentes tipos de relação jurídica (civil, tributária, previdenciária, trabalhista, penal etc.).

O que talvez pudesse gerar a (falsa) impressão que as técnicas de redistribuição do Código de Defesa do Consumidor e de dinamização são diferentes é o enfoque que cada uma das normas reguladoras dá às partes envolvidas e como faz o deslocamento do ônus probatório.

Com efeito, o Código de Defesa do Consumidor, construído sob o prisma da “proteção e defesa" do consumidor (artigo 1. ${ }^{\circ}$ da Lei 8.078/1990), que se presume vulnerável diante do fornecedor (artigo 4. ${ }^{\circ}$, inciso I da Lei 8.078/1990), prevê a técnica de distribuição dinâmica do ônus da prova a partir do exame da situação do consumidor, autorizando a transferência de ônus probatórios para o fornecedor sempre que, à luz do caso concreto e "segundo as regras ordinárias de experiência", a alegação do consumidor for verossímil ou (rectius, e) o consumidor for hipossuficiente (em relação ao fornecedor quanto à capacidade de produzir prova a favor ou contra essa alegação de fato). Ou seja, a desigualdade na capacidade probatória é apurada a partir da posição da parte mais "fraca". 
Já no projeto do novo Código de Processo Civil, artigo 370, a técnica é estabelecida pela ótica inversa, atribuindo o ônus de provar à parte em melhores condições de "obter prova do fato contrário", sempre que, "diante de peculiaridades da causa", a parte originalmente onerada se encontrar em um estado de "impossibilidade" ou "excessiva dificuldade" para se desincumbir do ônus da prova. Ou seja, a desigualdade na capacidade probatória é apurada a partir da posição da parte mais "forte".

Parece-nos inquestionável que a redação do texto do novo Código de Processo Civil é muito mais precisa e adequada para retratar a técnica (ainda que incompleta), não apenas por banir o verbo "inverter" (embora fosse algo imprescindível), mas também por retratar de forma mais explícita os requisitos autorizadores da técnica de distribuição dinâmica do ônus da prova, não obstante ainda não seja a redação ideal, uma vez que poderia ter mantido a referência à "verossimilhança" e tenha empregado equivocadamente a conjunção coordenativa alternativa "ou", em vez da conjunção coordenativa aditiva "e" na indicação dos demais requisitos a serem verificados em relação a cada uma das partes (impossibilidade ou excessiva dificuldade "E" maior facilidade da parte contrária).

Como vimos no item "5.3.2", a técnica de distribuição dinâmica do ônus da prova não se aplica na hipótese de ocasionar a prova diabólica inversa, pois não haveria desigualdade das capacidades probatórias das partes na espécie (a dificuldade ou impossibilidade seria de ambas as partes).

De qualquer forma, independentemente do ponto de vista que se observe a técnica, o resultado em ambos os casos é o mesmo (e não poderia ser diferente, afinal é a mesma técnica): restabelecer o equilíbrio perdido ou mesmo jamais existente entre as partes litigantes.

Pouco importa a norma prever se "inverte" o ônus da prova da parte A para a parte B ou que se "atribui" o ônus da prova para B em detrimento do ônus da prova da parte A. O resultado é sempre o mesmo: o ônus da prova desloca-se de uma parte à outra, de modo que os "pesos" probatórios se equivalham e a "balança" que mede os ônus probatórios das partes alinhe-se horizontalmente. 


\subsection{Poderes instrutórios do juiz, imparcialidade e influência sobre a distribuição dinâmica do ônus da prova}

Já nos referimos anteriormente sobre a relevância do incremento dos poderes instrutórios do juiz para a ampliação da cognição dos fatos e o aprimoramento da tutela jurisdicional a ser concedida. ${ }^{392}$ Neste tópico, procuraremos enfatizar especificamente a influência da ampliação dos poderes instrutórios do juiz sobre o âmbito de aplicação da técnica de distribuição dinâmica do ônus da prova.

Podemos afirmar que a ampliação dos poderes instrutórios do juiz é uma realidade no sistema processual civil brasileiro, em perfeita consonância com os valores constitucionais e as finalidades do processo, ${ }^{393}$ mas essa atuação ativa do juiz na colheita do material probatório deve ser sempre ponderada conforme a situação do caso concreto para que o magistrado não perca sua imparcialidade.

Somente mantendo o foco de sua atividade no aclaramento dos fatos e descoberta da verdade é que o juiz não irá ultrapassar a linha tênue da imparcialidade. ${ }^{394}$ Essa preocupação constante do juiz, contudo, não lhe retira o interesse no resultado da prova que tenha ordenado a realização.

Não vislumbramos mais como aceitar, ingenuamente, que o juiz, ao determinar a realização de determinada prova, não sabe o conteúdo dessa prova, pois, se ele entendeu necessária a realização de determinada prova, ele espera com ela obter algum resultado capaz de contribuir para a formação do seu convencimento. Ele pode não saber qual será o resultado da prova (positivo ou negativo), mas conhece quais alegações de fato podem ou não ser provadas com essa prova.

\footnotetext{
392 Vide item "1.2” do Capítulo 1.

393 Comentando as novidades trazidas pelo Código de Processo Civil de 1939, em especial quanto aos poderes instrutórios do juiz, ALFREDO BUZAID ressalta que "esta orientação adotada pelo Código brasileiro está em perfeita harmonia com a evolução do direito processual civil contemporâneo, que substituiu o juiz inerte pelo juiz ativo, conferindo-lhe atividade instrutória, não para sanar as deficiências da prova que a parte deixou de produzir, mas para formar o seu convencimento, como órgão jurisdicional, a quem toca a direção do processo" (Do ônus..., cit., p. 78).

394 Como defende TARUFFO, “[...] o juiz é verdadeiramente imparcial quando busca de modo objetivo a verdade dos fatos, fazendo dela o verdadeiro e exclusivo fundamento racional da decisão. Sob esse prisma, aliás, a busca da verdade torna-se um atributo essencial da imparcialidade do juiz" (Uma simples verdade..., cit., p. 144).
} 
A imparcialidade do magistrado não está em não querer o resultado da prova, afinal ele tem o dever de prestar um serviço de qualidade, coerente com a realidade dos fatos, e a instrução probatória é o melhor caminho para alcançar esse objetivo e esse dever. A garantia da imparcialidade é atingida quando o julgador se mostra indiferente quanto à parte que este resultado da prova pode favorecer (autor ou réu). ${ }^{395}$

Repita-se, o objetivo do juiz é a descoberta da verdade que, como vimos no Capítulo 1 da presente dissertação, será tanto mais próxima da realidade quanto melhor for a instrução na busca de elementos de prova, permitindo, com isso, um melhor julgamento, porquanto mais próximo do efeito pretendido pela norma de direito material aplicável na espécie.

Expostas essas considerações preliminares, à luz do sistema processual constitucional, quais são as possibilidades do juiz para melhor organizar a distribuição da atividade probatória ao longo do processo e como essa atuação judicial pode influenciar a distribuição dinâmica do ônus da prova?

Em um primeiro momento, que se inicia antes mesmo da instauração do processo e vai até o encerramento da fase postulatória, a regra geral e abstrata de distribuição do ônus da prova tem uma importante função de propulsionar a atividade probatória pelas partes, que são as que se encontram em melhores condições de informar ao juiz os meios de prova de que necessitam para provar as alegações que formulam, predefinindo as respectivas atribuições probatórias. Assim, nessa etapa preliminar, a função subjetiva do ônus da prova deve atuar para que as partes aparelhem o juiz das provas necessárias para demonstrar suas respectivas alegações.

Após a apresentação das alegações das partes e da especificação das provas, no momento do saneamento do processo, o julgador deverá determinar as provas que serão deferidas ou indeferidas, conforme os critérios de pertinência e necessidade, bem como apreciar os pedidos de eventual aplicação da técnica de distribuição dinâmica do ônus da prova, verificando a existência dos seus requisitos condicionantes, o que pode ensejar,

395 No entendimento de BEDAQUE, “[...] enquanto a solução (da lide) permanecer nas mãos do Estado, não pode o juiz se contentar apenas com a atividade das partes. A visão do 'Estado-social' não admite essa posição passiva, conformista, pautada por princípios essencialmente individualistas" (Poderes..., cit., p. 99). 
inclusive, uma ampliação do objeto da cognição, pois deverá a parte requerente comprovar $\mathrm{o}$ preenchimento dos requisitos, sempre oportunizando à parte contrária o diálogo e o contraditório. Constatada a pertinência do pedido, caberá ao juiz dar a oportunidade para a parte onerada se desincumbir, produzindo a prova necessária.

Superadas essas etapas, com ou sem dinamização do ônus da prova, poderão ainda existir lacunas quanto à comprovação de determinadas alegações de fato, seja por entender a parte que a alegação já está devidamente comprovada, seja por desconhecer outros meios de prova capazes de melhor elucidar o fato não provado.

Nessas hipóteses, não nos parece mais viável o uso da técnica de distribuição dinâmica do ônus da prova, haja vista que já existiu um "esgotamento" das partes quanto à sua capacidade de produzir provas e, diante da permanência do estado de dúvida do magistrado, qualquer atribuição de ônus teria um destino único: a derrota da parte onerada.

Contudo, como vimos, a imparcialidade do juiz resta assegurada pela sua busca pela verdade e seu não direcionamento do resultado do processo para uma das partes, de forma que, caso o magistrado ainda vislumbre a possibilidade de obtenção do conhecimento dos fatos por outros meios ainda não explorados pelas partes, que possam trazer novas luzes sobre a alegação de fato em questão, ele poderá (deverá), de ofício, com fundamento nos artigos 130 e 331, § 2. ${ }^{\circ}$, do Código de Processo Civil, determinar a realização da prova que entende pertinente para o aclaramento do fato.

Essa atuação ativa do juiz na obtenção da prova, entretanto, não descaracteriza eventual uso da técnica de distribuição dinâmica do ônus da prova em momento anterior do processo, ao menos em sua função objetiva, pois, na hipótese de a prova realizada a pedido do juiz se mostrar insuficiente à formação do seu convencimento, deverá ser proferida sentença com base na regra de distribuição do ônus da prova aplicada (estática ou dinâmica).

Com efeito, não é porque foi o juiz quem ordenou a realização da prova que esta será necessariamente concludente. A prova pode ser realizada e ainda assim não ser possível a formação do convencimento para um julgamento de certeza ou mesmo de 
probabilidade. Nessa hipótese, o julgamento com base na regra de distribuição do ônus da prova será inevitável.

Atento a essa possibilidade de julgamento com base na regra de distribuição do ônus da prova, parece-nos possível que, mesmo após a determinação do juiz para a realização da prova, a parte originalmente onerada por essa prova (por força da regra geral e abstrata) invoque a incidência da técnica de distribuição dinâmica do ônus da prova, para que os efeitos da insuficiência da prova ordenada de ofício pelo juiz recaiam sobre a parte contrária, desde que, obviamente, estejam preenchidos os requisitos autorizadores anteriormente examinados.

Por certo, é crível imaginar que a parte originalmente onerada sequer tinha conhecimento do ônus de produzir a prova ordenada de ofício pelo juiz, decorrente da fragilidade da sua defesa, da (falsa) crença de já ter se desincumbido de todos os ônus probatórios que lhe competiam, ou mesmo por desconhecimento da fonte ou do meio de prova.

No entanto, diante da atuação do juiz, ordenando a realização de prova para a comprovação de determinada alegação de fato formulada por essa parte, fica evidenciado que essa parte continua onerada e as circunstâncias do caso concreto podem demonstrar a sua incapacidade ou extrema dificuldade de produzir a prova se tivesse que fazê-lo espontaneamente, sem prejuízo da maior capacidade probatória da parte contrária.

Assim, a nosso ver, ainda que o juiz se valha de poderes instrutórios, que devem ser amplos, porém supletivos aos ônus probatórios, não fica inviabilizado o emprego da técnica de distribuição dinâmica do ônus da prova, não mais como instrumento de organização e produção da prova, mas como regra de julgamento em caso de insuficiência da prova realizada a pedido do juiz.

Tal conclusão não se alteraria mesmo se admitíssemos uma incidência dos poderes instrutórios do juiz desde o início da instrução probatória, em um modelo quase inquisitorial, em que fosse possível a designação de provas ex officio antes mesmo de oportunizar às partes sua indicação e realização, porquanto, como sustentamos, a técnica de dinamização dos ônus probatórios seria aplicável mesmo após a decisão que ordena a 
produção da prova, pois inexiste certeza de que essa prova terá um resultado capaz de dirimir o estado de dúvida do julgador, sendo sempre possível, ao final, o julgamento com base na regra de distribuição do ônus da prova, que deverá observar a regra estática e, eventualmente, a regra dinâmica, quando aplicada no curso do processo.

Outro ponto relevante a ser examinado relacionado à matéria é em que medida o juiz perde sua imparcialidade quando determina a realização de determinada prova de ofício com fundamento, exclusivamente, na desigualdade da capacidade probatória das partes.

Para BEDAQUE, embasado na garantia da igualdade substancial, a atuação ativa do juiz, determinando a realização de provas de ofício, que deixaram de ser produzidas por uma das partes por se encontrar em uma situação de inferioridade, não afronta o dever de imparcialidade do julgador, pois o resultado da prova é sempre incerto e "a ausência de iniciativa probatória pelo juiz corresponde a considerá-lo mero assistente passivo de um duelo entre o lobo e o cordeiro".396

Em sentido contrário, DANIEL PENTEAdo DE CASTRo sustenta que a finalidade dos poderes instrutórios é o aclaramento dos fatos para melhor decidir, e, ao ordenar a realização de provas de ofício em função de uma desigualdade na capacidade probatória das partes, o juiz perderia, ao menos em parte, sua imparcialidade, pois estaria beneficiando, em tese, a parte mais fraca, ainda que o resultado da prova seja incerto, uma vez que, se a prova for conclusiva, a parte onerada será beneficiada, e, se não for conclusiva, a situação não será alterada. ${ }^{397}$

Em nossa opinião, apenas a constatação da situação de desigualdade na capacidade probatória não deveria ensejar no juiz o uso dos poderes instrutórios, com o objetivo de suprimir essa desigualdade, sob o risco de efetivamente perder sua

\footnotetext{
$396 \quad$ Poderes..., cit., p. 111.
}

$397 \quad$ Nas palavras do referido autor, “[...] se a iniciativa probatória se justifica exclusivamente como ato voltado a equacionar eventuais deficiências técnicas entre as partes, significa admitir que em parte a imparcialidade resta suprimida ou excepcionada, porquanto a hipossuficiência permitiria ao magistrado, em teses, beneficiar uma das partes, embora ainda não se saiba o resultado da prova. [...] Logo, a determinação da produção de determinada prova de ofício pelo juiz, sob a exclusiva premissa de que uma das partes é deficiente tecnicamente para conhecer a possibilidade de produção daquela prova [...] não coaduna com o princípio da imparcialidade [...]" (Poderes..., cit., p. 246). 
imparcialidade. O campo de incidência dos poderes instrutórios é outro, qual seja reduzir o estado de dúvida do julgador. Ao avançar em favor da parte mais "fraca", o juiz acaba por conceder-lhe um benefício no ônus probatório, e mesmo no resultado final do processo, sem qualquer contrapartida à parte contrária.

Como adverte SiDNEY DA Silva Braga, o juiz, ao agir de ofício diante de uma situação de desigualdade, em vez de assegurar a justiça, implanta uma ideia discriminatória de que o juiz

[...] somente deve preocupar-se em envidar esforços na busca do resultado, o mais justo possível, quando houver sensível desnível socioeconômico entre os litigantes, significando que, quando ambos forem ricos ou ambos forem pobres, o Estado, em última análise, não se interessa pelo grau de justiça alcançado pelo processo. $^{398}$

A solução, na espécie, para que o juiz cumpra seu dever de imparcialidade seria, em nosso sentir, aplicar a distribuição dinâmica do ônus da prova, ordenando que a parte em melhores condições de produzir a prova assim o faça, desde que, obviamente, presentes os demais requisitos anteriormente examinados, impondo-lhe o ônus da prova e, assim, reequilibrando as condições das partes. 


\section{CAPÍTULO 6 \\ INCIDÊNCIA PRÁTICA DA TÉCNICA DE DISTRIBUIÇÃO DINÂMICA DO ÔNUS DA PROVA NO PROCESSO CIVIL}

\subsection{Quanto à pertinência do estudo prático}

O estudo de qualquer instituto processual não é totalmente pleno sem que ele seja colocado à prova. Essa assertiva se torna ainda mais pertinente quando o objeto do estudo é uma técnica voltada a aspectos práticos e instrumentais do processo (a instrução probatória), que somente será efetivamente pertinente se possível extrair-lhe algum resultado positivo. Afinal, toda e qualquer técnica que tenha por objetivo apenas criar mais entraves ao curso do processo é de todo indesejada, ou mesmo impertinente.

É a partir dessa confrontação com a prática que poderemos extrair alguma conclusão sobre a amplitude da aplicabilidade da técnica de distribuição dinâmica do ônus da prova, e em que medida essa técnica fornece subsídios para a efetividade da tutela jurisdicional.

Diante de tais motivos, o presente capítulo se dedicará a realizar a transposição da ideia para a matéria, testando sua pertinência prática e sua real relevância à luz dos mecanismos de flexibilização do ônus da prova atualmente existentes, bem como os meios de prova disponíveis.

Antes, contudo, analisaremos alguns julgados do Superior Tribunal de Justiça que aplicaram a técnica dinâmica, para verificar se está ocorrendo o emprego adequado da técnica e quais os requisitos que têm sido exigidos.

Para concluir, procuraremos diferenciar o mecanismo de dinamização de algumas técnicas de redução do módulo de valoração da prova, que, por vezes, são confundidas, mas não guardam relação direta, porquanto tem finalidades distintas e incidência em diferentes momentos do curso processual. 


\subsection{Exame jurisprudencial de aplicação da técnica de distribuição dinâmica do ônus da prova}

Para iniciarmos esse estudo prático da aplicação da técnica de distribuição dinâmica do ônus da prova, parece-nos primordial examinar como os Tribunais pátrios têm se comportado quanto sua incidência nos casos concretos. Focaremos, essencialmente, o posicionamento do Superior Tribunal de Justiça, do qual selecionamos os seguintes julgados, por ordem cronológica:

a) Recurso Especial n. ${ }^{\circ}$ 69.309/SC, $4 .^{a}$ Turma, rel. Min. Ruy Rosado de Aguiar, $j$. 18.06.1996, DJ 26.08.1996, JBCC 194/55, LEXSTJ 89/155 e RSTJ 87/287.

O objeto da ação cinge-se à reparação de danos por erro médico. O Tribunal de origem entendeu pela aplicação da técnica dinâmica de distribuição do ônus da prova, ainda que não mencionada expressamente, atribuindo ao médico "a prova de que atuou com toda a diligência possível”, ficando provado, contudo, que assim não agiu, pois ficou comprovada a relação de causalidade entre o erro médico e as lesões, e o paciente teve que se submeter a outras cirurgias posteriormente, além de ter ficado tetraplégico.

O Superior Tribunal de Justiça, confirmando o Acórdão a quo, asseverou que a decisão

[...] se colocou ao lado da orientação que hoje predomina na matéria sobre culpa médica, que é a da teoria (sic, técnica) dinâmica da prova, segundo a qual cabe ao profissional esclarecer o juízo sobre os fatos da causa, pois nenhum outro tem como ele os meios para comprovar o que aconteceu na privacidade da sala cirúrgica.

Vê-se, portanto, o acolhimento pelo Superior Tribunal de Justiça, já no ano de 1996, da técnica de distribuição dinâmica do ônus da prova, na hipótese mais recorrente mencionada por doutrinadores, correspondente à responsabilidade por erro médico, em especial durante ato cirúrgico, atribuindo-se ao próprio médico o ônus de provar que agiu diligentemente, conforme as boas práticas da medicina.

A solução, contudo, poderia ser dada pela regra de deslocamento do ônus da prova prevista no Código de Defesa do Consumidor, pois seria possível enquadrar a 
situação do paciente como "consumidor" de serviços médicos, razão pela qual o caso se resolveria à luz da norma consumerista.

b) Recurso Especial n. ${ }^{\circ}$ 823.122/DF, 5. ${ }^{a}$ Turma, rel. Min. Napoleão Nunes Maia Filho, j. 14.11.2007, DJ 18.02.2008.

O tema em debate é a anistia de servidor e sua reintegração ao cargo público do qual fora demitido, que, de acordo com o autor, teria ocorrido por motivações políticas. Segundo o Tribunal a quo, caberia ao autor a prova de sua alegação, razão pela qual manteve a sentença de improcedência.

Para o Superior Tribunal de Justiça, contudo, a prova, no caso concreto, somente poderia se dar de forma indireta "e deve decorrer da interpretação do contexto e das circunstâncias do ato apontado como de motivação política”. E continua:

[...] a prova direta, material ou imediata é rigorosamente impossível em caso dessa espécie. Impor ao autor que a faça significa, em verdade, impor-lhe a chamada prova diabólica, de produção impossível, porque os afastamentos dos cargos, à época, eram disfarçados; [...] Dest'arte, compete à Instituição que promoveu o ato demissionário demonstrar a inexistência de motivação política.

Mais uma vez, agiu com acerto o Superior Tribunal de Justiça ao aplicar, implicitamente, a técnica de distribuição dinâmica do ônus da prova, pois a imposição do ônus ao autor lhe acarretaria uma "prova diabólica", enquanto o órgão estatal responsável pela demissão dispõe de diversos meios para comprovar que a demissão havia sido regular.

c) Recurso Especial n. ${ }^{\circ} 896.435 / P R$, 3. ${ }^{a}$ Turma, rel. Min. Nancy Andrighi, j. 27.10.2009, DJe 09.11.2009.

A ação versa sobre nulidade de contrato e devolução de parcelas pagas à administradora de consórcios, julgada improcedente e confirmada em segunda instância sob o fundamento de que caberia à autora a prova da celebração do contrato de consórcio, documento que não foi apresentado pela autora por alegado extravio do documento.

Para a Ministra Relatora, "numa perspectiva dinâmica do processo, é possível ao juiz admitir a propositura da ação principal sem esses documentos, se formulado pedido 
incidental para sua exibição", de sorte que a autora não teria necessariamente o ônus da prova da existência do contrato, que poderia ser obtido com o incidente de exibição de documento previsto nos artigos 355 e seguintes do Código de Processo Civil. Se, mesmo após o incidente de exibição, o terceiro obrigado pela exibição não apresentasse o contrato,

[...] por força da inexistência desse documento ou do desconhecimento quanto a seu paradeiro, competiria ao juízo, diante de uma clara hipótese de prova diabólica, optar, na sentença entre: (i) impor à autora o ônus da comprovação da existência do contrato e dos valores pagos, nos termos do art. 333, I, do CPC, julgando, com isso, improcedente o pedido; (ii) inverter o ônus dessa prova, nos termos do art. $6^{\circ}$, inc. VIII, do CDC, caso entenda possível aplicar tal diploma à controvérsia; (iii) distribuir, mesmo que não aplicável o $\mathrm{CDC}$, de maneira dinâmica o ônus objetivo da prova, como regra de julgamento, com base na assunção, pelo réu, do risco pela impossibilidade de apresentação do documento.

Com essa fundamentação, foi dado provimento ao Recurso Especial e determinada a devolução do processo à origem, para que fosse instaurado o procedimento incidental de exibição, o que, em nosso entendimento, é acertado, sem prejuízo da aplicação subsidiária da técnica de dinamização, caso o documento não venha a ser exibido, diante da probatio diabolica. Voltaremos ao tema da exibição incidental de documento ou coisa e sua relação com a técnica dinâmica no item "6.3.1" deste Capítulo.

O deslinde do caso também poderia se dar pela aplicação subsidiária do Código de Defesa do Consumidor, expressamente referido no voto vencedor, caso a exibição do documento restasse inviabilizada, porquanto a relação entre consórcio e consorciado enquadra-se como de consumo.

d) Recurso Especial n. ${ }^{\circ}$ 619.148/MG, 4. ${ }^{a}$ Turma, rel. Min. Luis Felipe Salomão, j. 20.05.2010, DJe 01.06.2010, RDDP 89/136 e RT 900/191.

A questão discutida nesse caso é a quem deve ser atribuído o ônus da prova de que os valores depositados em conta corrente têm natureza salarial e, portanto, são impenhoráveis. Em processo de execução de título extrajudicial, foi indeferido o pedido de bloqueio de contas do executado, por não estar comprovado que os valores depositados não são provenientes de salário. O Tribunal de Justiça de Minas Gerais, ao julgar o Agravo de Instrumento interposto pelo exequente, manteve a decisão, por entender que "incumbe ao exequente o ônus da prova de que o saldo encontrado na conta corrente do executado não é proveniente de salário, a teor do art. 333, I, do CPC”. 
O Superior Tribunal de Justiça, dando o correto entendimento à matéria, com a aplicação apenas da regra estática de distribuição do ônus da prova na espécie, posicionouse no sentido de que,

[...] sendo direito do exequente a penhora preferencialmente em dinheiro (art. 655, inciso I, do CPC), a impenhorabilidade dos depósitos em contas correntes, ao argumento de tratar-se de verba salarial, consubstancia fato impeditivo do direito do autor (art. 333, inciso II, do CPC), recaindo sobre o réu o ônus de prová-lo.

A corroborar seu posicionamento, o Ministro Relator ressalta que a imposição do ônus ao autor, "a par de ser prova diabólica, negativa, somente poderia ser atendida mediante a prática de ilícito penal, consistente em violação de sigilo bancário". E arremata: “à luz da teoria da carga dinâmica da prova, não se concebe distribuir o ônus probatório de modo a retirar tal incumbência de quem poderia fazê-lo mais facilmente e atribuí-la a quem, por impossibilidade lógica e natural, não o conseguiria”.

A síntese final do Acórdão ilustra com clareza o requisito essencial para a aplicação da técnica de distribuição dinâmica do ônus da prova, qual seja a verificação de desigualdade nas capacidades probatórias das partes, consistente na extrema dificuldade ou impossibilidade da parte onerada e a maior facilidade de produzir prova da parte contrária, de modo que agiu bem o Superior Tribunal de Justiça ao refutar a aplicação da aludida técnica no caso em exame.

e) Recurso Ordinário em Mandado de Segurança n. ${ }^{\circ}$ 27.358/RJ, 3. ${ }^{a}$ Turma, rel. Min. Nancy Andrighi, j. 05.10.2010, DJe 25.10.2010 e RDDP 95/135.

O cerne do debate está na definição da extensão dos efeitos de decisão judicial sobre bem imóvel em relação ao terceiro adquirente, que alega ter realizado a aquisição do bem litigioso de boa-fé, e a quem incumbe o ônus da prova da boa-fé. O promitente comprador, que não integrou a ação anulatória de leilão e arrematação promovida pelos antigos proprietários, impetra mandado de segurança contra a decisão que determina a reintegração de posse e cancelamento de todos os registros de transmissão da propriedade na matrícula do imóvel a partir da arrematação. O Tribunal a quo denega a segurança com base na não comprovação da boa-fé pelo impetrante. 
No julgamento do Recurso Ordinário, o Superior Tribunal de Justiça entendeu que, por força da disposição contida no $\S 3 .^{\circ}$ do artigo 42 do Código de Processo Civil, incidem sobre o impetrante os efeitos da coisa julgada da ação que envolve objeto litigioso, não sendo cabível a alegação de que é terceiro de boa-fé, haja vista que

[...] há uma presunção relativa de ciência do terceiro adquirente acerca da litispendência, cumprindo a ele, nos termos do art. 333 do CPC, demonstrar que adotou todos os cuidados que dele se esperavam para a concretização do negócio, notadamente a verificação de que, sobre a coisa, não pendiam ônus judiciais ou extrajudiciais capazes de invalidar a alienação.

E, ainda, seria a hipótese de aplicação da distribuição dinâmica do ônus da prova, pois "conclui-se que o terceiro adquirente reúne plenas condições de demonstrar ter agido de boa-fé, enquanto a tarefa que incumbiria ao seu adversário, de provar o conluio daquele com o alienante, se mostra muito mais árdua”.

Não vislumbramos, entretanto, a hipótese de cabimento da técnica de dinamização no caso em análise. Se o impetrante alega como fundamento do seu mandado de segurança que agiu como terceiro de boa-fé para obter a não incidência dos efeitos da coisa julgada da ação envolvendo o objeto litigioso, pela regra estática de distribuição do ônus da prova, que é exatamente a mesma aplicável a todas as demais ações civis, o ônus da prova dessa alegação incumbe exclusivamente ao impetrante, com a ressalva de que essa prova deve ser pré-constituída, haja vista a peculiaridade do rito especial do mandamus.

A existência da presunção relativa de conhecimento da ação originária pelo terceiro adquirente não altera em nada a conclusão supra, pois continua sendo incumbência do impetrante o ônus da prova de que adquiriu o bem litigioso de boa-fé. Em verdade, a presunção, no caso, reforça a tese de que o autor deve fazer prova de sua alegação, bem como daquela que seja capaz de elidir o fato presumido. Voltaremos ao tema das presunções e sua relação com a distribuição dinâmica do ônus da prova no item " 6.3 ” deste capítulo.

Portanto, embora a solução dada ao caso concreto esteja correta, atribuindo o ônus da prova ao impetrante, não se trata de hipótese de dinamização, mas apenas da incidência da regra estática de distribuição do ônus da prova. 
f) Recurso Especial n. ${ }^{o}$ 1.189.679/RS, 2. ${ }^{a}$ Seção, rel. Min. Nancy Andrighi, j. 21.11.2010, DJe 17.12.2010.

O ponto de divergência reside na possibilidade ou não de se exigir de instituição financeira a apresentação do extrato bancário dos poupadores que pleiteiam o pagamento dos expurgos inflacionários decorrentes de planos econômicos (Bresser e Verão, no caso).

Na visão da Ministra Relatora (com a qual concordamos), a hipótese enquadrase à regra estabelecida no inciso VIII do artigo 6. do Código de Defesa do Consumidor, mas, ainda que não fosse aplicável a redistribuição do ônus da prova, o banco teria o ônus de exibir o extrato bancário do poupador por força do incidente de exibição de documento ou coisa, que importaria numa redistribuição do ônus da prova por força "do inadimplemento, pelo réu, de seu dever de apresentação dos documentos solicitados”. Por fim, é sustentada, ainda, a aplicação da distribuição dinâmica do ônus da prova, "decidindo, conforme a situação concreta, a quem serão impostas as consequências pela impossibilidade de produção probatória".

Em nosso sentir, o Acórdão tem algumas falhas que precisam ser examinadas.

O primeiro aspecto é a definição dos institutos aplicáveis na espécie. Como vimos anteriormente, ${ }^{399}$ a redistribuição prevista no Código de Defesa do Consumidor e a dinamização são, em essência, a mesma técnica, daí por que inexiste razão em tratá-las como duas coisas distintas.

O segundo ponto diz respeito à ordem de incidência das técnicas probatórias. Como teremos oportunidade de discorrer mais detidamente adiante, ${ }^{400}$ na confrontação entre a exibição de documento ou coisa e a técnica de dinamização deve prevalecer a primeira, exigindo-se da parte detentora do documento ou coisa a sua exibição, sob pena de serem presumidos os fatos que se pretendia provar com o documento ou coisa não exibida.

\footnotetext{
399 Vide item "5.9” do Capítulo 5.

$400 \quad$ Vide item "6.3.1” deste Capítulo.
} 
O terceiro equívoco da decisão está em atribuir como efeito da não exibição do documento uma redistribuição do ônus da prova. Como já adiantamos no parágrafo anterior, o efeito da não exibição do documento ou coisa é a admissão, pelo juiz, "como verdadeiros os fatos que, por meio do documento ou da coisa, a parte pretendia provar”, conforme determina o artigo 359 do Código de Processo Civil. Ou seja, há uma presunção (relativa) de que tais fatos são verdadeiros, e não uma redistribuição do ônus da prova. ${ }^{401}$

De qualquer forma, a solução dada ao caso concreto nos parece acertada, atribuindo à instituição financeira o ônus de exibir os extratos financeiros dos poupadores relativamente aos períodos dos expurgos inflacionários discutidos.

g) Recurso Especial n. ${ }^{o}$ 1.084.371/RJ, 3. ${ }^{a}$ Turma, rel. Min. Nancy Andrighi, j. 01.12.2011, DJe 12.12.2011 e RDDP 108/126, e Embargos de Declaração no Recurso Especial n. ${ }^{\circ}$ 1.084.371/RJ, 3. ${ }^{a}$ Turma, rel. Min. Nancy Andrighi, j. 05.06.2012, DJe 28.09.2012.

Discute-se, nesse caso, a distribuição do ônus da prova no processo monitório embargado e o eventual cabimento da técnica de dinamização. Em primeira e segunda instâncias os Embargos foram rejeitados, sob o fundamento de que a ré-embargante não teria provado os alegados vícios de consentimento contidos no título.

No entendimento do Superior Tribunal de Justiça, inicialmente, deve-se ter presente que a inversão do contraditório na ação monitória (somente se instaura por iniciativa do devedor-embargante) não acarreta, em regra, redistribuição do ônus da prova, sendo irrelevante o fato de as alegações de defesa serem formuladas incidentalmente (contestação) ou por meio de ação autônoma (embargos).

No caso em exame, a embargante questionou o efetivo repasse dos valores objeto da confissão de dívida que assinara (fato impeditivo do direito do autor-embargado), tendo a prova pericial dos livros contábeis demonstrado o não registro do valor no caixa da embargante. Para a Ministra Relatora, ainda que, pela regra estática, a prova coubesse à

401 No mencionado item "6.3.1" deste Capítulo voltaremos ao tema e criticaremos o posicionamento de que a presunção importa em redistribuição do ônus da prova. 
embargante, e, no limite do que lhe era cabível, ela se desincumbiu do seu ônus, o caso comporta a aplicação da distribuição dinâmica, porquanto apenas o autor-embargado poderia comprovar a efetiva entrega da quantia à ré-embargante.

E, conforme consignado no Acórdão,

[...] cuidava-se, aliás, de prova singela. Bastava ao recorrido apresentar os comprovantes de transferência para a recorrente e/ou os comprovantes das despesas por ele suportadas em benefício da empresa, totalizando o valor objeto da confissão de dívida.

Com esse entendimento, foi dado parcial provimento ao Recurso Especial, para acolher os Embargos e julgar improcedente a Ação Monitória.

A decisão nos parece correta no tocante ao acolhimento da técnica de distribuição dinâmica do ônus da prova, contudo peca por não dar oportunidade à parte que se tornou onerada para se desincumbir do seu ônus, o que, como vimos, fere a garantia do contraditório.

Esse equívoco, contudo, foi superado no julgamento dos Embargos de Declaração opostos pelo autor-embargado, os quais foram recebidos com efeitos modificativos, e "reconhecido o equívoco do tribunal de origem quanto à valoração e na distribuição do ônus da prova, e, permanecendo dúvida quanto à existência ou não do crédito, os autos devem retornar à origem para a devida complementação probatória”.

h) Recurso Especial n. ${ }^{o}$ 1.135.543/SP, 3. ${ }^{a}$ Turma, rel. Min. Nancy Andrighi, j. 22.05.2012, DJe 07.11.2012.

As partes litigam sobre reparação de danos por uso indevido de imagem não autorizada em reportagem sobre passeata LGBT, sob a acusação de que os autores foram indevidamente associados ao movimento, enquanto, em verdade, apenas transitavam pelo local onde o evento seria realizado. Ação julgada procedente e mantida no Tribunal de Justiça, ainda que os autores não tenham trazido aos autos cópia da reportagem, veiculada em um canal de notícias da internet. 
No entendimento do Superior Tribunal de Justiça, por se tratar de matéria veiculada na internet, caracterizada pela fluidez de conteúdo, os autores não tinham o dever de guardar a reportagem, mas esta sempre seria recuperável pelo canal de notícias que a divulgou. Ademais, os autores comprovaram "repercussão social do fato, juntando aos autos e-mails por eles recebidos de colegas de trabalho e de amigos, nos quais a notícia é mencionada".

Assim, para a Ministra Relatora,

[...] em situações em que o julgador está diante de fatos cuja comprovação, pelo autor, seja impossível ou particularmente difícil, enquanto para o réu a produção da prova contrária apresente-se mais simples, o interesse público na justa composição do litígio recomenda que, em regime de solidariedade, colaboração e boa-fé processual, seja do réu, e não do autor, o ônus da produção da referida prova.

Embora a solução encontrada no caso nos pareça adequada para a aplicação da distribuição dinâmica do ônus da prova, seria possível cogitar, na espécie, de algo mais simples, como o incidente de exibição de documento ou coisa a que já nos referimos anteriormente, atribuindo uma presunção de veracidade às alegações dos autos caso a ré se negasse a exibir a íntegra da reportagem considerada ofensiva.

i) Agravo Regimental no Agravo de Decisão Denegatória de Recurso Especial n. ${ }^{\circ}$ 216.315-RS, 2. ${ }^{a}$ Turma, rel. Min. Mauro Campbell Marques, j. 23.10.2012, DJe 06.11.2012.

O processo versa o recebimento de diferenças de correção monetária e juros remuneratórios sobre os créditos de empréstimo compulsório sobre energia elétrica. A ação foi julgada improcedente porque o autor não trouxe aos autos o cálculo exato do valor pretendido. O Tribunal a quo anulou a sentença, determinando o retorno dos autos à origem para que a ré apresentasse todos os registros dos valores de empréstimo compulsório, inscritos no cadastro de contribuintes necessários para a elaboração do cálculo.

No Superior Tribunal de Justiça a decisão foi mantida, pois, no entendimento do Ministro Relator, não existe qualquer ilegalidade em exigir a apresentação dos 
documentos solicitados, e "porque a teoria (sic, técnica) de distribuição dinâmica do encargo probatório propicia a flexibilização do sistema, e permite ao juiz que, diante da insuficiência da regra geral prevista no art. 333 do CPC, possa modificar o ônus da prova, atribuindo-o à parte que tenha melhor condições de produzi-la”.

Mais uma vez, embora a incidência seja possível, a opção pela técnica dinâmica não nos parece a mais acertada, pois o caso poderia ser resolvido pela aplicação do incidente de exibição de documento ou coisa.

j) Recurso Ordinário em Mandado de Segurança n. ${ }^{\circ}$ 38.025-BA, $1 .^{a}$ Turma, rel. Min. Sérgio Kukina, j. 23.09.2014, DJe 01.10.2014.

O mandamus foi impetrado contra ato omissivo do Secretário da Educação do Estado da Bahia, em razão de errônea reclassificação do impetrante, servidor público inativo, após o advento da Lei n. ${ }^{\circ}$ 4.794/1988 e Lei n. ${ }^{\circ}$ 8.889/2003, tendo sido denegada a segurança por insuficiência do arcabouço probatório, não obstante a solicitação (não atendida) de apresentação de documentos formulada pelo juiz à autoridade coatora.

No entendimento do Ministro Relator, seria a hipótese de aplicação da distribuição dinâmica dos ônus probatórios, pois

\footnotetext{
[...] tenha ou não havido prévia recusa administrativa no fornecimento da ficha funcional do autor, tal documento, em poder da Administração, revelava-se, e ainda se revela, necessário e essencial para a prova dos fatos alegados pelo impetrante na exordial, devendo-se, por tal razão, conferir o máximo rendimento prático possível à requisição judicial prevista no art. $6 .^{\circ}, \S 1 .^{\circ}$, da Lei n..$^{\circ}$ $12.016 / 09$.
}

Portanto, foi dado provimento ao Recurso Ordinário para que os autos retornassem ao Tribunal a quo e "ali se renove, com a urgência e o vigor necessários à sua efetivação, a ordem requisitória anteriormente deferida pela Desembargadora Relatora", o que, a nosso ver, parece a solução mais adequada, mas que, em sua essência, não equivale à técnica de dinamização.

A peculiaridade no caso do mandado de segurança, que, em regra, segue a regra estática de distribuição do ônus da prova, é a existência de uma norma (artigo 6. ${ }^{\circ}, \S$ 1. ${ }^{\circ}$, da Lei n. ${ }^{\circ}$ 12.016/2009) que autoriza o juiz a solicitar a exibição de documento que 
embase o pedido do impetrante e que se encontre "em repartição ou estabelecimento público ou em poder de autoridade que se recuse a fornecê-lo por certidão ou de terceiro", à semelhança do incidente de exibição de documento ou coisa, mas que não impõe qualquer consequência à recusa.

Diante dessa omissão quanto aos efeitos da negativa, podemos cogitar duas situações em caso de não exibição do documento: (i) aplicar por analogia o disposto no artigo 359 do Código de Processo Civil e considerar presumidos os fatos alegados pelo impetrante, embora isso possa afrontar o conceito de "direito líquido e certo"; ou (ii) aplicar a distribuição dinâmica do ônus da prova, transferindo ao impetrado o ônus da prova do fato contrário, o que, de qualquer forma, acarreta o mesmo problema da hipótese anterior.

Caberá ao julgador, no exame do caso concreto e das outras provas que instruem o processo, definir a melhor solução a ser aplicada, embora a primeira nos pareça a que melhor atende os interesses da parte onerada, que por suas próprias forças não conseguiu obter o documento necessário à comprovação de suas alegações.

\subsection{Presunções legais decorrentes de comportamentos omissivos dos litigantes}

A técnica da distribuição dinâmica do ônus da prova também pode ser confrontada com outro mecanismo comumente utilizado para apuração dos fatos, em especial aqueles cuja prova é difícil ou mesmo impossível, que é a presunção.

As presunções são inferências que o julgador tira de um ou mais fatos conhecidos para firmar um fato desconhecido, desde que, encadeados logicamente, numa relação de causalidade, mediante ligações estabelecidas entre uns e outros fatos de acordo com as máximas de experiência. ${ }^{402}$ Os indícios, por sua vez, são os fatos auxiliares que constituem "sinais" de outros fatos sempre que entre uns e outros possa se estabelecer uma ligação de acordo com as máximas de experiência, que é a presunção.

\footnotetext{
402 BARBOSA MOREIRA, José Carlos. As presunções e a prova. Temas de direito processual civil:
} primeira série. 2. ed. São Paulo: Saraiva, 1988. p. 55-71. 
Uma vez configurada a presunção, a atribuição do ônus da prova deixa de seguir a regra geral e abstrata, pois, pela presunção, aquele que estava inicialmente onerado pela prova do fato presumido deixa de ter tal ônus, cabendo à parte contrária o ônus da prova de fatos que descaracterizem a presunção (não incidência no caso concreto ou não ocorrência do fato presumido) ou mesmo de fatos que retirem do fato presumido os efeitos pretendidos pela parte que o alegou.

Pela presunção, dá-se por provado o fato desconhecido, mediante a comprovação do fato conhecido (indício), extraindo o julgador, pelas máximas da experiência, o fato que se presume ter ocorrido ou não. Há, portanto, uma desoneração da parte em provar o fato presumido, o qual é tido como efetivamente provado, ainda que apenas no campo intelectivo do magistrado.

As presunções são classificadas em absolutas ou relativas, cujo critério é a possibilidade ou não de realização de prova contrária à presunção (para descaracterização da presunção), ou, ainda, em legais ou judiciais, conforme sejam previstas em norma legal ou instituídas pelo magistrado no exame do caso concreto.

Ou seja, ocorrendo a presunção relativa, que admite prova em contrário, a parte a quem a alegação do fato presumido aproveita fica dispensada de prová-la (não há mais o ônus de prová-la), pois tal fato é admitido pelo juiz como provado. A parte contrária, portanto, assume o ônus de descaracterizar a presunção (provar que no caso concreto a hipótese cogitada na presunção não se aplica ou que o fato presumido não ocorreu ou se deu de forma diversa).

Em paralelo, também caberá a essa parte o ônus da prova dos fatos que alegar para desconstituir o fato presumido (sejam constitutivos, quando alegados pelo autor, sejam impeditivos, modificativos ou extintivos, se alegados pelo réu), desde que se trate, evidentemente, de uma presunção relativa.

O que se verifica, na presunção relativa, é que o reconhecimento da presunção desonera a parte que alegou o fato presumido de prová-lo, ${ }^{403}$ criando, por seu turno, um

403 Nesse sentido, o artigo 334, inciso IV do Código de Processo Civil é expresso ao afirmar que "não dependem de prova os fatos: (IV) em cujo favor milita presunção legal de existência ou de 
novo ônus para a parte contrária (o ônus de descaracterizar a presunção) e antecipando para esta parte o ônus que já possuía de provar as alegações dos fatos com efeitos contrários aos do fato presumido.

Logo, não há que falar em redistribuição do ônus da prova nas hipóteses de presunção relativa, pois não há transferência de ônus de uma parte à outra, mas apenas a supressão do ônus da prova em relação ao fato presumido (sem prejuízo do ônus de provar o indício que lhe dá suporte), o que acarreta uma antecipação do ônus da parte contrária em relação às suas próprias alegações que eventualmente tenha formulado para extinguir, modificar ou impedir os efeitos do fato presumido, além de se atribuir um novo ônus àquele que é prejudicado pela presunção, consistente em descaracterizar sua hipótese de incidência no caso concreto ou provar que o fato presumido não ocorreu (caso a presunção seja de que tenha ocorrido) ou que efetivamente ocorreu (caso a presunção seja de que não tenha ocorrido).

Assim, não concordamos com a doutrina que vislumbra na presunção uma hipótese de redistribuição do ônus da prova, bem como não concordamos sequer com aqueles que defendem que a presunção tem como "efeito prático" a redistribuição, pois, repita-se, não há transferência de ônus. ${ }^{404}$

Com efeito, imaginando um caso concreto em que a presunção beneficia o autor da ação, se o fato não fosse presumido, pela regra geral e abstrata de distribuição do ônus da prova prevista no artigo 333 do Código de Processo Civil, caberia ao autor o ônus da sua prova. E apenas se o autor se desincumbisse desse ônus é que se cogitaria do ônus do réu em provar os fatos impeditivos, modificativos e/ou extintivos que tenha eventualmente alegado.

Tratando-se de um fato "em cujo favor milita presunção", não há qualquer transferência de ônus de parte a parte. $\mathrm{O}$ autor, no nosso exemplo, simplesmente estaria desonerado de provar o fato presumido, que será recebido pelo juiz como provado, equivalente, do ponto de vista teórico, à desincumbência do ônus pelo autor, cujo efeito

veracidade”. Se o fato não depende de prova, não há como imputar o ônus de prová-lo à parte que o alega.

404 O "efeito prático" da presunção é, apenas e tão somente, que a parte favorecida fica desonerada de provar a alegação correspondente ao fato presumido. 
imediato é exigir do réu a prova das alegações que formulou com o objetivo de retirar do fato presumido o efeito postulado pelo autor, sob pena de, não o fazendo, ou fazendo de modo insatisfatório, a ação ser julgada com base na regra de distribuição do ônus da prova, e necessariamente desfavorável ao réu, pois em relação ao fato presumido é como se o autor tivesse se desincumbido do seu ônus de prová-lo.

Ainda nos valendo do exemplo citado, o réu, além do ônus de provar as alegações que eventualmente tenha formulado, decorrente da regra insculpida no inciso II do artigo 333 do Código de Processo Civil, diante do reconhecimento da presunção relativa, será imbuído de um novo ônus, consistente em provar a descaracterização da presunção, o que poderá ocorrer pela comprovação de que a hipótese legal ou judicial de presunção não se aplica no caso concreto, ou, ainda, pela prova de que o fato presumido não se verificou da forma como se pressupunha que tivesse ocorrido.

É exatamente em relação a essa última hipótese que podemos cogitar um ponto de tangenciamento entre as técnicas da presunção e da distribuição dinâmica do ônus da prova, porquanto em ambas o que se verifica é a desoneração de uma das partes e o incremento do ônus da prova da parte contrária, cabendo em ambas as hipóteses à parte que se tornou onerada provar que, na realidade, o fato presumido ou aquele de difícil comprovação pela parte originalmente onerada não se revela condizente com a realidade.

De fato, a parte que se torna onerada pela presunção ou pela distribuição dinâmica do ônus da prova assume a incumbência de provar que aquilo que a parte contrária alegou (e que não necessitará ser mais provado por essa parte) não confere com a verdade, cabendo à parte onerada trazer à tona essa verdade que ainda se encontra desconhecida pelo julgador. O não atendimento desse mister implica, salvo se por outros meios essa verdade se revelou, no mesmo resultado nas duas técnicas: o julgamento desfavorável àquele que se tornou onerado no curso da ação.

A aproximação desses dois mecanismos, ao menos quanto aos efeitos sobre a parte "prejudicada", acarreta o estabelecimento de uma relação de proporcionalidade inversa entre eles, pois, quanto mais amplas as hipóteses de presunção, menor a incidência da técnica de distribuição dinâmica do ônus da prova, que se torna menos necessária, haja vista que o seu objetivo principal, de desonerar a parte que teria dificuldade em produzir a 
prova da alegação formulada, está sendo atingido por um caminho mais seguro (decorrente, em muitos casos, de norma legal) e eficiente, porquanto na presunção o fato é acolhido como provado, até prova em contrário, dispensando a prova, sem prejuízo de eventual comprovação em sentido contrário pela parte "prejudicada".

Não obstante, é possível vislumbrar uma aplicação conjunta dos dois institutos, na hipótese de a parte a quem a presunção beneficia (mas ainda não reconhecida) se encontrar em uma situação de dificuldade de provar o fato logicamente relacionado àquele que se quer seja reconhecido como presumido.

Nessa situação, diante da reconhecida desigualdade na capacidade probatória das partes, o magistrado poderia se valer da técnica de distribuição dinâmica do ônus da prova para exigir da parte em melhores condições a prova contrária ao indício que levaria à presunção, sob pena de o indício ser tido como provado e, consequentemente, acolhida a presunção, desonerando a parte beneficiada de provar o fato presumido, que também será considerado provado.

\subsubsection{Exibição de documento ou coisa}

O Código de Processo Civil estabelece nos artigos 355 a 363 o procedimento para a exibição de documento ou coisa que se encontre em poder de uma das partes ou de terceiros, que não traz esse documento ou coisa espontaneamente aos autos, podendo o juiz impor essa exibição, sob pena de serem presumidas as alegações de fato que se pretendia provar com o documento ou coisa não apresentada, caso quem deva exibi-la seja da parte. $^{405}$

Esse mecanismo merece especial atenção à luz da técnica de distribuição dinâmica do ônus da prova, sobretudo porque é capaz de suprimir, em grande parte, as hipóteses de seu cabimento. 
Em determinadas circunstâncias, para que a parte originalmente onerada de provar certa alegação de fato consiga se desincumbir de tal ônus, ela precisará se valer de informações contidas em determinado documento e de certo objeto, aos quais essa parte não tem acesso, seja por estar em poder da parte contrária ou por se encontrar na posse de terceiros.

A relação da parte onerada como o documento ou a coisa pode decorrer de um direito real ou pessoal que esta parte tem em relação ao documento ou coisa, ou simplesmente de um interesse juridicamente tutelado ao uso dele. Em tais hipóteses, a obrigação de exibir decorre do direito substancial.

A exibição do documento ou da coisa pode decorrer, ainda, do mero interesse na apuração da verdade, que pode ser tanto da parte como o é da Justiça, sendo permitido à parte exigir de quem o detenha a exibição como medida de satisfação de um interesse pessoal ou estatal, como um "dever cívico" inerente a todos os cidadãos de contribuir para a Justiça, ${ }^{406}$ reflexo dos deveres de lealdade e cooperação a que já nos referimos anteriormente, e de acordo com o disposto nos artigos 339, 340, inciso III, e 341, incisos I e II, todos do Código de Processo Civil.

No tocante àquele que possui o documento ou coisa, pode existir um interesse de resistência à exibição, porque este revela a prova de uma alegação favorável à outra parte, ou mesmo porque sua exibição pode causar-lhe prejuízos morais e patrimoniais. Contudo, se não for a hipótese de acolhimento da recusa da parte detentora do documento ou coisa, em relação a essa parte, a ordem de exibição exarada pelo juiz impõe-lhe um ônus, consistente em fazer a exibição ou, na sua falta, presumir verdadeiros os fatos que a parte pretendia provar com o documento ou coisa que não foi exibida.

$\mathrm{Na}$ hipótese de a exibição vir a ser exigida de terceiro, ela deve ser compreendida como uma obrigação, quando corresponder ao direito da parte de exigi-la, ou mesmo como o dever "de cooperar, com os meios de que dispõe, para o melhor funcionamento da justiça", ${ }^{407}$ tal qual o dever de testemunhar, sem prejuízo das hipóteses

406 AMARAL SANTOS, Moacyr. Comentários ao Código de Processo Civil. 4. ed. Rio de Janeiro: Forense, 1988. v. 4, p. 121.

407 CALMANDREI, Piero. Conseguenze dela mancata esibizione di documenti in giudizio. Studi sul processo civile. Padova: Cedam, 1934. v. 3, p. 55. 
de recusa, sempre com o objetivo de melhor esclarecimento dos fatos circunscritos ao caso concreto, não sendo, contudo, o caso de acolher a presunção de veracidade do documento ou da coisa caso o terceiro não o exiba em juízo.

A aproximação que podemos fazer entre a exibição e a técnica da distribuição dinâmica do ônus da prova consiste em que em ambas, diante da desigualdade da capacidade probatória, o juiz afasta, ao menos momentaneamente, a regra geral e abstrata de distribuição do ônus da prova, que exige de cada parte a realização das provas de suas respectivas alegações, transferindo parte do ônus probatório de uma parte à outra.

Como vimos, um dos requisitos para o uso da técnica dinâmica é a desigualdade na capacidade probatória das partes, o que poderia ser imaginado nas hipóteses em que uma parte alega determinado fato, mas que para prová-lo precisa que a parte contrária exiba determinado documento ou coisa, encontrando-se inacessível à parte originalmente onerada.

Um exemplo bem comum dessa hipótese é a alegação de prejuízo no rendimento de caderneta de poupança decorrente de expurgos inflacionários provocados por planos econômicos, tais como aqueles que ocorreram no fim dos anos 80 e início dos anos 90 no Brasil (Planos Bresser, Verão, Collor I e Collor II). O correntista de determinada instituição financeira alega que possuía saldo em conta poupança no período de incidência do expurgo, mas não possui nenhum extrato comprovando essa alegação. $O$ autor apenas prova que tinha uma conta poupança naquele banco. O juiz, diante da contestação do banco negando a existência de saldo no período (sem nenhuma comprovação documental), como deve proceder?

Os entusiastas da técnica de distribuição dinâmica do ônus da prova poderiam invocar sua aplicabilidade na espécie, por entender que existe verossimilhança na alegação da parte, afinal há elementos de que o autor era correntista do banco, e existe hipossuficiência ou melhores condições de o banco produzir a prova contrária, porquanto detém o registro das movimentações dos seus clientes.

Em nosso sentir, contudo, tratando-se de documento ou coisa certa a ser exibida, deve prevalecer a técnica da exibição de que estamos tratando neste tópico, a qual 
tem a finalidade primordial de provar uma alegação de fato mediante a prova documental associado a uma presunção relativa de veracidade da alegação da parte originalmente onerada. Não podemos nos olvidar de que a técnica dinâmica é marcada pela subsidiariedade, devendo ser esgotados todos os demais mecanismos de organização da prova antes de sua aplicação.

Por certo, uma vez que (i) seja determinado o documento ou coisa cuja exibição é exigida da parte, tal como o extrato bancário no exemplo que utilizamos acima; (ii) essa prova tenha uma finalidade específica (provar uma alegação de fato que a parte onerada, por seus próprios meios, não conseguiria produzir); e (iii) estejam demonstradas as circunstâncias que tal documento ou coisa existe e está em poder da parte contrária ou de terceiro, o juiz deve se valer da técnica da exibição, exigindo diretamente do detentor do documento ou coisa a sua exibição, sob pena de lhe serem aplicadas as cominações legais (a admissão pelo juiz como verdadeira a alegação de fato que se pretendia provar), no caso de não exibição infundada pela parte, conforme artigo 359 do Código de Processo Civil, ou a expedição de mandado de apreensão e responsabilidade por crime de desobediência, no caso de não exibição infundada pelo terceiro, a teor do que dispõe o artigo 362 do Código de Processo Civil. ${ }^{408}$

Essa "admissibilidade" das alegações de fato como verdadeiras não pode ser interpretada em sua literalidade. Trata-se, em verdade, de uma hipótese de presunção relativa, e como tal depende de que outros fatos logicamente relacionados ao fato presumido sejam provados, ou seja, continua vigendo o sistema do livre convencimento motivado, cabendo ao juiz valorar o conjunto probatório para extrair a sua convicção.

O Código de Processo Civil de 1939 dava melhor tratamento à matéria, prevendo que, em caso de não exibição do documento ou coisa pela parte, "desde que só exame do documento possa confirmar ou destruir as alegações do requerente, o juiz poderá considerá-las provadas", mas desde que "verossímeis e estiverem coerentes com as demais provas dos autos" (artigo 219).

408 A Súmula n. 372 do Superior Tribunal de Justiça consolidou o entendimento de que não seria aplicável multa cominatória na ação de exibição, e, embora se refira, em princípio, à medida cautelar de exibição, prevista nos artigos 844 e 845 do Código de Processo Civil, é pacífica a sua aplicação ao incidente de exibição sobre o qual estamos discorrendo. 
Voltando ao exemplo da exibição do extrato bancário com o saldo do autor no momento do expurgo inflacionário, se o banco se recusar a apresentá-lo, como deveria decidir o juiz? Se for reconhecido que o poupador faz jus ao valor correspondente ao expurgo, qual valor deve ser considerado como saldo existente em conta no momento de sua incidência?

As soluções encontradas pelos Tribunais são as mais diversas, mas entendemos que a melhor consistiria em tomar como base o saldo existente em conta em data precedente mais próxima à data do expurgo que tenha sido comprovado e atualizá-lo até a data do expurgo, para, em seguida, com base no valor encontrado, calcular o valor do expurgo. Adota-se como premissa que os valores mantidos em caderneta de poupança são, em regra, para reserva futura e que, costumeiramente, o poupador não realiza saques desse valor. De qualquer forma, para confirmação dessa inferência, haveria necessidade de o poupador apresentar extratos bancários de outros períodos, demonstrando que possuía saldo e que o mantinha sob a custódia do banco por um período.

Não é demais destacar que o problema permaneceria o mesmo no caso de aplicação da técnica de distribuição dinâmica do ônus da prova e o banco não se desincumbisse do ônus de provar a inexistência de saldo na poupança do autor no período de apuração do expurgo inflacionário. De fato, qual o valor a considerar para a base de cálculo? A solução, em nosso sentir, teria que seguir a mesma linha de raciocínio que propomos no parágrafo anterior, procurando extrair das demais provas produzidas algum elemento para fixação do quantum.

De qualquer forma, para os fins aqui objetivados, a conclusão que extraímos é que, mesmo em situações em que se poderia invocar a aplicação da técnica de distribuição dinâmica do ônus da prova, se a prova que se pretende produzir for documental, referir-se a documento ou coisa determinada e estiver em poder de alguém identificável, deve o magistrado dar preferência ao incidente de exibição, que atribui à pessoa específica o ônus ou o dever de exibir o documento ou coisa solicitada, impondo cominações específicas em caso de não cumprimento da ordem, de sorte a atingir uma gama mais ampla de pessoas, inclusive aqueles que não são partes no processo. 
Por outro lado, a técnica de dinamização da distribuição do ônus da prova terá sempre uma incidência subsidiária, como na hipótese de o dever de exibição vier a ser exigido de um terceiro e este se recusar ou não puder fazer a exibição, em que não é aplicável a presunção relativa antes examinada, e o juiz poderá se valer da dinamização para tentar obter a prova por outros caminhos, ou, ainda, quando o documento ou coisa não for determinada e o detentor for, necessariamente, a parte contrária, desde que sejam preenchidos os requisitos examinados no item " 5.3 " e subitens.

\subsubsection{Perícia médica}

Desde a promulgação do Código Civil, criou-se uma nova modalidade de presunção relativa, corroborada pela jurisprudência dominante do Superior Tribunal de Justiça, em relação à parte que se nega a submeter-se a uma perícia médica, presumindo-se verdadeiras as alegações de fato que se pretendiam provar com a perícia, aplicável, em larga escala, nas ações de reconhecimento de paternidade.

Se, por um lado, a exibição tem grande valia para a realização de prova documental (documentos ou coisas), em relação à produção de prova pericial médica, sempre existirão entraves à sua efetividade, sobretudo quando envolver o exame da parte contrária.

A dificuldade resiste, em grande parte, ao posicionamento consolidado do Supremo Tribunal Federal de que não é possível exigir à força que alguém se submeta a uma perícia médica, por afronta à intimidade, à dignidade da pessoa humana e à inviolabilidade do corpo humano conforme leading case de 1994, no julgamento do Habeas Corpus n. ${ }^{\text {7 }} 71.373 .^{409}$

409 O voto vencedor do Ministro Marco Aurélio assim se posiciona sobre o tema: “[...] para mim a violência (contra a parte que deveria se submeter ao exame de DNA) é ímpar e discrepa, sobremaneira, não só da ordem constitucional em vigor, como também das normas instrumentais comuns aplicáveis à espécie. [...] Ninguém está compelido, pela ordem jurídica, a adentrar a Justiça para questionar a respectiva paternidade, da mesma forma que há consequências para o fato de vir aquele que é apontado como pai e recusar-se ao exame que objetive o esclarecimento da situação. É certo que compete aos cidadãos em geral colaborar com o Judiciário, ao menos na busca da prevalência dos respectivos interesses e que o sacrifício - na espécie, uma simples espetadela - não é tão grande assim. Todavia, princípios constitucionais obstaculizam a solução dada à recusa. Refirome, em primeiro lugar, ao da legalidade, no que ninguém é obrigado a fazer ou deixar de fazer alguma coisa senão em virtude de lei, [...] a intimidade, a vida privada, a honra e a imagem [...]. A recusa do 
O Brasil adota, ao contrário de alguns sistemas estrangeiros, como o alemão e o suíço, a não obrigatoriedade de a parte submeter-se à perícia médica, o que coloca o julgador diante de um dilema: ignorar a prova que poderia resultar da perícia ou atribuir efeito probatório à recusa da parte que deveria realizar o exame e não o fez.

Ao se optar pela primeira alternativa, o juiz deverá tomar o fato como não provado, e se os demais elementos de prova forem insuficientes para a formação do convencimento do julgador, este deverá decidir pela regra geral e abstrata de distribuição do ônus da prova, atribuindo a derrota àquele que não se desincumbiu do seu ônus.

O Código Civil de 2002, em consonância com o modelo cooperativo de processo, parece ter optado pela segunda alternativa, atribuindo um efeito negativo à conduta omissiva da parte que se recusa a se submeter à perícia médica.

A previsão está contida nos artigos 231 e 232 do Código Civil e a par das discussões doutrinárias sobre a utilidade de tais dispositivos, e sobre se se trata de mera orientação ao juiz, presunção legal ou judicial ou, ainda, uma fixação legal, que refogem dos estritos limites deste trabalho e o enfoque ora examinado, temos para nós que, embora o texto legal não seja o mais adequado, estamos tratando de uma hipótese de presunção legal relativa, que não pode ser interpretada de modo estritamente literal, mas consoante as regras gerais das presunções relativas.

Estabelece o aludido artigo 231 a regra de que quem se recusa ao exame médico não pode beneficiar-se de tal atitude, refletindo o princípio geral de que ninguém pode se valer de sua própria torpeza (nemo tenetur se detegere).

Examinando tal regra à luz da distribuição do ônus da prova, vislumbramos duas situações: se a recusa em realizar o exame partir da própria parte a quem o exame constitui fundamento de sua pretensão, a recusa resolve-se pela regra geral e abstrata do artigo 333 do Código de Processo Civil, admitindo como não provada a alegação que

Paciente há de ser resolvida não no campo da violência física, da ofensa à dignidade humana, mas no plano instrumental, reservado ao Juízo competente - ou seja, o da investigação de paternidade - a análise cabível e a definição, sopesadas a prova coligida e a recusa do réu". Disponível em <http://redir.stf.jus.br/paginadorpub/paginador.jsp?docTP=AC\&docID=73066>. Acesso em: $2 \mathrm{dez}$. 2014. 
dependeria de confirmação pela prova pericial médica. Ainda que pouco provável de ocorrer na prática, porquanto a recusa contrariaria o próprio interesse da parte, é possível imaginar essa hipótese, de modo que há uma coerência sistêmica entre o artigo 231 do Código Civil e o artigo 333 do Código de Processo Civil.

A segunda situação, que realmente nos interessa nesse momento, dá-se quando a alegação de fato a ser provada pela perícia é formulada por uma das partes (sendo esta parte, portanto, quem tem o ônus da prova) e o exame pericial precisa ser realizado pela parte contrária. Se a parte que deveria se submeter ao exame se recusa a fazê-lo, essa parte não poderá se valer da recusa como tese de defesa, alegando que a parte contrária não produziu a prova de sua alegação de fato, a teor do citado artigo 231 do Código Civil. Entretanto, como deve agir o juiz diante de tal impasse?

Parece-nos que, mais uma vez, seria possível invocar a aplicação da técnica de distribuição dinâmica do ônus da prova, haja vista que podemos vislumbrar a presença dos requisitos de sua aplicabilidade, em especial a desigualdade na capacidade probatória das partes. Com efeito, a parte que deveria se submeter ao exame pericial detém total controle da prova, bastando sua aquiescência em se sujeitar ao exame para que a prova seja produzida.

Contudo, o emprego da técnica de distribuição dinâmica da prova esbarra, na espécie, nas limitações constitucionais da intimidade, da inviolabilidade do corpo e da dignidade da pessoa humana que, conforme o entendimento jurisprudencial consolidado, impedem a obrigatoriedade da realização do exame. ${ }^{410}$

Por certo que se poderia argumentar que a técnica de distribuição dinâmica do ônus da prova não gera uma "obrigatoriedade", mas de qualquer forma atribuiria um ônus à parte que deve se submeter ao exame que, se descumprido, implicaria o reconhecimento da pretensão da parte contrária, mesmo sem outros elementos de prova, o que, no nosso modo de pensar, não coaduna com a finalidade da técnica dinâmica.

410 Não ignoramos que, em verdade, pode haver um verdadeiro conflito de valores constitucionais em jogo, sobretudo quando imaginamos os casos de filiação, em que também deve ser assegurado ao suposto filho o direito à família, à identidade biológica, entre outros. A doutrina e mesmo a jurisprudência já revelam situações em que se sustenta a obrigatoriedade do exame. 
A solução que nos parece mais apropriada na situação em exame é a prevista no artigo 232 do Código Civil, que, diante do reconhecimento de que, na prática, ninguém pode ser compelido à força a realizar o exame médico, estabeleceu uma presunção relativa para a hipótese de recusa, que servirá de indício ao fato que se pretendia provar com a perícia médica.

Não se trata, por óbvio, de se extrair exclusivamente da recusa o indício para o fato não provado. A parte a quem a presunção beneficia continua tendo o ônus de provar outros fatos "graves, preciosos e concludentes" 411 que possam levar à conclusão de que o fato não provado tenha um alto grau de probabilidade de que tenha ocorrido.

Assim, utilizando o exemplo da ação de investigação de paternidade, principal campo de incidência das regras em comento, se o suposto pai se recusar a realizar o exame de DNA, ainda assim o pretenso filho deve produzir provas documentais e/ou testemunhais do vínculo, ainda que efêmero, entre a sua mãe e o suposto pai. A mera recusa, desacompanhada de qualquer outro indício da relação, não tem o condão de preencher os requisitos da presunção na espécie.

Essa interpretação restritiva na hipótese (de que bastaria a recusa para o reconhecimento do fato não provado) ganhou força, ao menos no âmbito doutrinário, com a edição da Súmula n. 301 do Superior Tribunal de Justiça, a qual estabelece que, "em ação investigatória, a recusa do suposto pai a submeter-se ao exame de DNA induz presunção juris tantum de paternidade".

O exame acurado dos precedentes que deram origem à referida súmula e dos casos que se seguiram, contudo, reforça a tese de que a mera recusa não configura a presunção, a qual necessita da conjugação de outros indícios para reconhecer o fato probandum.

411 A colocação é de HUMBERTO THEODORO JÚNIOR, que complementa asseverando que "não bastam simples suposições ou meras conjunturas. $\mathrm{O}$ nexo entre os fatos conhecidos (indícios) e a conclusão (presunção) tem de apresentar-se verossímil, por corresponder de fato ao que comumente acontece em situações iguais. Deve estabelecer-se, portanto, uma rigorosa relação de causalidade entre as premissas e a conclusão" (A prova indiciária no novo Código Civil e a recusa ao exame de DNA. In: DIDIER JR., Fredie; MAZZEI, Rodrigo (Org.). Prova, exame médico e presunção: o artigo 232 do Código Civil. Salvador: JusPodivm, 2006. p. 122). 
Ou seja, mesmo no caso de recusa da parte em realizar o exame médico, a parte que alegou o fato pendente da prova pericial continuaria com o ônus de provar os indícios que dão suporte ao resultado pretendido com o exame.

Por força da presunção, esta parte estará desonerada da prova da alegação de fato objeto da perícia. Já a parte que se recusou a realizar o exame médico adquire o ônus de provar os fatos contrários ao fato presumido ou que desarticulem a presunção, desde que provados os indícios do vínculo parental, sem prejuízo do ônus que já lhe incumbia em decorrência da regra geral e abstrata do artigo 333 do Código de Processo Civil.

Vislumbrando um caso concreto, podemos imaginar uma ação de investigação de paternidade. Determinada a produção do exame de DNA, o suposto pai se nega a realizá-lo, mesmo após ter sido intimado pessoalmente e com a advertência da possibilidade de ser presumido como pai.

O juiz passa, então, à análise dos indícios, para verificar se existe alguma prova concludente de que o suposto pai e a mãe tiveram algum vínculo e mantiveram relação sexual em momento contemporâneo à concepção.

Presentes os indícios, aliado à recusa na produção da prova pericial, o juiz poderá reconhecer a paternidade, salvo se o suposto pai se desincumbir do seu ônus e provar, por exemplo, que era estéril ao momento da concepção ou que a mãe mantinha relações com outros parceiros (plurium concubentum), desarticulando a presunção de que seria o pai do autor da aludida ação.

Para os fins propostos neste trabalho, a conclusão que extraímos é de que, diante da existência de um facilitador da prova por meio do emprego da técnica da presunção relativa, também em relação à prova pericial médica não vislumbramos a aplicação da técnica de distribuição dinâmica do ônus da prova como o melhor mecanismo de instrução probatória, sobretudo porque poderia conduzir a resultados dissociados da realidade, uma vez que prescindiria até mesmo dos indícios (bastaria a "verossimilhança" ou a mera desigualdade da capacidade probatória), o que não ocorre na hipótese da presunção. 


\subsubsection{Interrogatório, depoimento pessoal e confissão ficta}

O depoimento pessoal e a confissão também podem gerar hipóteses de presunção e por isso devem ser analisadas como técnicas de flexibilização da distribuição dos ônus probatórios, justificando-se, ainda, o exame do interrogatório, por sua similaridade com o depoimento pessoal em alguns aspectos.

Como já ressaltamos ao longo do presente trabalho, o modelo atual de processo não admite que as partes ajam de maneira escusa e oblíqua, sendo-lhes sempre exigido um comportamento leal e cooperativo para o esclarecimento da situação fática e jurídica em debate, conforme se extrai dos deveres previstos nos artigos 14, incisos I e II, 339 e 340, inciso I, todos do Código de Processo Civil.

Para que o juiz possa obter de forma direta das partes os esclarecimentos que julgar necessários ao deslinde da causa, o sistema prevê dois mecanismos: o interrogatório e o depoimento pessoal.

O elemento comum desses dois institutos é a obrigatoriedade (“dever", no interrogatório, e "ônus", no depoimento pessoal) do comparecimento da parte intimada a ser ouvida, mas diferem quanto ao momento de realizarem-se, aos legitimados para requerê-los, às finalidades pretendidas e, principalmente, quanto aos efeitos da recusa.

Em relação ao momento, o artigo 342 do Código de Processo Civil estabelece que o juiz pode ordenar o interrogatório "em qualquer estado do processo", enquanto o depoimento deve ser ordenado, no procedimento ordinário, no despacho saneador, ou posteriormente a ele, e, no procedimento sumário, antes da audiência, devendo ser realizado, no procedimento ordinário, na audiência de instrução e julgamento, conforme previsto no artigo 452, inciso II do Código de Processo Civil. Disso decorre que podem suceder diversos interrogatórios, mas o depoimento pessoal em regra é uno.

A legitimidade para requerer o interrogatório é exclusiva do juiz, o qual irá ouvir as partes para aclarar os fatos da causa, sem prejuízo de poder extrair das oitivas elementos para o seu convencimento. Já o depoimento pessoal pode ser ordenado de ofício pelo juiz ou requerido pelas partes, para que seja ouvida a parte contrária, quanto ao 
conhecimento que detém dos fatos alegados pela outra parte e, essencialmente, para se obter do depoente a confissão.

Essa é, aliás, a finalidade principal do depoimento pessoal, sobretudo quando requerido pela parte: obter da parte contrária a confissão provocada quanto aos fatos que alegou contra esta parte, dispensando a prova desse fato por outros meios. Por certo que a confissão também pode ser obtida no interrogatório, mas não se trata de sua finalidade, podendo ocorrer de forma não provocada.

O depoimento pessoal é, portanto, o meio de prova pelo qual se obtém a prova de determinada alegação de fato pelo reconhecimento de tal fato pela parte contrária. A confissão é a prova resultante do reconhecimento colhido no depoimento pessoal, sem prejuízo dos demais meios de confissão, inclusive extrajudiciais.

Realizada essa pequena nota introdutória, cumpre-nos examinar tais institutos à luz da distribuição do ônus da prova, nos quais se verificam algumas diferenças.

A par da obrigatoriedade do comparecimento, a recusa da parte de participar do interrogatório não lhe traz efeitos negativos quanto ao seu ônus probatório. De fato, a recusa não implica a pena de confissão, dado o caráter exclusivamente informacional que reveste o interrogatório. O recalcitrante, contudo, não deverá sair impune.

Por força dos deveres de colaboração e lealdade, previstos nos artigos 14, incisos I e II, 339 e 340, inciso I do Código de Processo Civil, a recusa em prestar informações em interrogatório poderá acarretar a imposição das sanções da litigância de má-fé, por ofensa aos incisos II e III do artigo 17 do Código de Processo Civil, além de a conduta omissiva da parte poder influenciar negativamente o juiz na formação do seu convencimento, afinal quem não se dispõe a auxiliar o juízo no esclarecimento dos fatos presume-se que tenha algo a esconder. ${ }^{412}$

412 Como assevera MOACYR AMARAL SANTOS, o não comparecimento da parte ao interrogatório poderá confirmar a má-fé, "sem prejuízo de o juiz poder extrair da atitude do litigante desidioso argumentos probatórios que lhe sejam desfavoráveis. Quem não se propõe a esclarecer, presume-se tenha algo a ocultar" (Comentários..., cit., v. 4, p. 74). 
No depoimento pessoal, a parte tem o ônus de comparecer e depor, e, em caso de recusa, opera-se a presunção de confissão, a teor do disposto nos $\S \S 1 .^{\circ}$ e $2 .^{\circ}$ do artigo 343 do Código de Processo Civil.

Ou seja, semelhante ao que expusemos no item precedente quanto à recusa na realização da perícia médica, a parte que regularmente intimida a comparecer em juízo para prestar depoimento pessoal sobre os fatos alegados pela parte contrária se nega a comparecer ou, comparecendo, se recusa a depor, autoriza o juiz ao reconhecimento de que tais fatos são presumivelmente verdadeiros, desonerando a parte que os alegou como fundamento de sua pretensão de prová-los. Da mesma forma, transfere-se ao renitente o ônus da prova de suas alegações contrárias ao do seu adversário, bem como antecipando o ônus de provar as alegações de fatos com efeitos impeditivos, modificativos ou extintivos eventualmente por essa parte formulados, além de atribuir-lhe o ônus de descaracterizar a presunção.

A recusa, em si, não equivale à confissão, mas à presunção de confissão. Ela é a manifestação do interesse em permanecer inerte, calado. A confissão, por seu turno, exige uma atitude comissiva, um animus confitendi. No entanto, o estado de inatividade da parte contraria os interesses sociais e jurídicos do processo, pois cria embaraços à descoberta dos fatos e ao adequado pronunciamento do direito, e por isso deve resultar em uma situação de desvantagem para a parte que se opõe a falar.

Caberá ao magistrado examinar, à luz do caso concreto, se a recusa foi abusiva ou não, bem como se as alegações de fato sobre as quais recairá a presunção de confissão são "verossímeis e coerentes com as demais provas dos autos", como previa o $\S 2 .^{\circ}$ do artigo 229 do Código de Processo Civil de 1939, texto que infelizmente não foi repetido no Código atual, mas que continua aplicável, ao menos intrinsecamente, no raciocínio do juiz para aplicação da presunção na espécie.

Em vez da presunção da confissão, poderia o juiz se valer da técnica de distribuição dinâmica do ônus da prova? Em tese, parece-nos que sim, embora, já nos adiantando, não se nos afigura o procedimento mais adequado. 
Imaginemos que uma das partes, em determinado processo, formule uma alegação de fato e afirme que tal fato somente pode ser provado pelo depoimento da pessoa do seu adversário na causa, por serem autor e réu os únicos que tiveram acesso a esse fato e a parte não pode pedir seu próprio depoimento pessoal. A parte contrária simplesmente nega a ocorrência de tal fato. No saneamento do feito, poder-se-ia cogitar da incidência da técnica de distribuição dinâmica do ônus da prova, afinal a parte onerada encontra-se impossibilitada de provar e a parte contrária é a própria fonte da prova, aquele único que pode produzi-la e revelar a veracidade ou não veracidade da alegação. A aplicação da técnica de distribuição dinâmica do ônus da prova, contudo, não nos parece adequada porque, com a transferência do ônus à parte detentora do conhecimento do fato controvertido, esta somente poderia se desincumbir de tal ônus mediante o seu próprio depoimento pessoal, o que não é permitido pelo sistema, de forma que a prova seria impossível para esta parte se tal ônus lhe incumbisse.

Como vimos, a técnica de distribuição dinâmica do ônus da prova não se aplica quando ocasionar prova diabólica inversa, de modo que a solução a ser adotada no exemplo é a determinação da oitiva da parte em depoimento pessoal, impondo-lhe os ônus do comparecimento e da prestação das informações, sob pena de presunção de confissão dos fatos controvertidos de que detém conhecimento.

Se a parte comparece e presta o depoimento, fica superada a hipótese de presunção, cabendo ao juiz o livre convencimento sobre o depoimento prestado. Se a parte comparece, presta depoimento e confessa os fatos alegados pela parte contrária, a prova é considerada produzida e examinam-se as demais alegações de fato das partes. Se a parte não comparece ou, se o faz, nega-se a depor, verificadas a coerência e verossimilhança das alegações que se pretendia provar pelo depoimento com o restante do conjunto probatório, aplica-se a presunção de confissão, transferindo ao presumido confitente o ônus de provar as alegações que fundamentam as suas pretensões e/ou que desarticulem a presunção, sob pena de, não o fazendo ou fazendo de forma insuficiente, ser-lhe imposta a derrota na ação.

Sob o ponto de vista da eficiência e da eficácia, o sistema da presunção de confissão, observadas as cautelas naturais a todas as hipóteses de presunção, mostra-se muito mais adequado na espécie do que a técnica de distribuição dinâmica do ônus da 
prova, que, inclusive, pode ser inviabilizada caso se verifique a ocorrência de prova diabólica inversa.

\subsection{Distribuição do ônus da prova por convenção entre as partes}

Tema pouco explorado na doutrina, a regra de distribuição do ônus da prova também pode ser flexibilizada, com atribuição dos respectivos ônus, por acordo entre as partes, conforme previsão expressa do parágrafo único do artigo 333 do Código de Processo Civil, que independe de homologação judicial. ${ }^{413}$

De acordo com o referido dispositivo legal, é livre a convenção das partes sobre a distribuição do ônus da prova, salvo se "recair sobre o direito indisponível da parte" (inciso I) ou "tomar excessivamente difícil a uma parte o exercício do direito" (inciso II).

Trata-se de regra que interfere diretamente na distribuição do ônus da prova e, não obstante o posicionamento contrário à admissibilidade de tal convenção, como encontramos nas lições de LOPES DA COSTA, ${ }^{414}$ CHIOVENDA $^{415}$ e ECHANDÍA, ${ }^{416}$ a corrente majoritária, sustentada, entre outros, por MOACYR AMARAL SANTOS, ${ }^{417}$ Lessona, ${ }^{418}$

413 Como afirma BARBOSA MOREIRA, “a eficácia é, em regra, imediata, independente de homologação da convenção pelo juiz. Ainda a considerar-se limitado aos 'atos processuais em sentido estrito' o âmbito da incidência direta do art. 158 do CPC, o qual destarte não abrangeria as convenções celebradas em sede extrajudicial, inexiste razão para que estas se submetam, no particular, a regime diverso. Assim, diante de convenção que distribua o onus probandi de modo diferente do previsto no art. 333, o que cabe ao órgão judicial é, pura e simplesmente, se for o caso, e desde que o ato não seja nulo, aplicar as regras convencionais, em vez das legais, para decidir a lide. Não há necessidade de pronunciamento homologatório, salvo disposição legal em contrário [...]". (Convenções das partes sobre matéria processual. Revista de Processo, São Paulo: RT, v. 9, n. 33, p. 191, jan. 1984; grifos do autor).

414 Segundo o aludido autor, "a admissão do princípio dispositivo não significa, porém, que as partes possam orientar o processo a seu talante. Dono do processo (dominus processi) é o juiz [...] não sendo este obrigado, na formação das bases da sentença, a aceitar as convenções das partes" (A prova..., cit., p. 48).

415 Para o mestre italiano, assim "como não se pode pretender em juízo a observância de contratos relativos às provas, também não se pode pretender a observância de uma convenção concernente ao ônus de prova", pois "[...] se referem a uma atividade alheia (a atividade do juiz), sobre cuja regulação não pode influir a vontade das partes, a não ser quando a lei o disponha expressamente" (Instituições..., cit., v. 2, p. 390).

Teoria..., cit., t. 1, p. 518.

Comentários..., cit, v. 4, p. 30-31.

Teoría..., cit., v. 1, p. 220. 
ROSENBERG ${ }^{419}$ e CARNELUTTI, ${ }^{420}$ e está amparada no texto normativo, ao menos entre nós, desde a promulgação do atual Código de Processo Civil.

Quando o juiz se depara com uma convenção (que pode ser judicial ou extrajudicial) entre as partes litigantes distribuindo o ônus da prova de forma diversa daquela prevista no caput do artigo 333 do Código de Processo Civil, cabe-lhe examinar, antes mesmo do início da fase probatória, para a adequada organização das provas a serem produzidas, se a referida convenção preenche os requisitos de validade, quais sejam: não versar sobre direitos indisponíveis e não estabelecer uma probatio diabolica para a parte onerada.

Curioso observar que, especificamente para a hipótese de distribuição convencional do ônus da prova, o legislador preocupou-se com a questão da possibilidade de desigualdade na capacidade probatória das partes, como se esta somente pudesse existir em tal hipótese, o que, como vimos, não reflete a verdade, pois pode decorrer de eventos naturais oriundos da condição das partes e do próprio direito material em discussão (como nas relações de consumo).

De qualquer forma, a novidade trazida pelo legislador de 1973 já é um grande avanço do sistema para aproximar o juiz do caso concreto e suas vicissitudes, impedindo que sejam impostos ônus probatórios a determinada parte, normalmente em uma fase préprocessual, como condição para realização de um negócio, mas que, uma vez instaurado o processo, impedem ou praticamente inviabilizam o acesso da parte onerada ao Poder Judiciário, por importar em uma dificuldade extrema ou mesmo impossibilidade de produzir prova das alegações que sustentam a sua pretensão. ${ }^{421}$

419 Segundo o autor, "estos contratos son válidos por cuanto las partes pueden disponer del objeto del contrato, en cuanto dichos contratos no infringen el derecho imperativo, y porque también en la práctica han sido considerados siempre como válidos, pues se abstienen de toda disposición en el sentido de prescribir al juez cuándo y en qué condiciones debe admitir aquella incertidumbre, y sólo contienen precauciones para el caso de que el juez no considere un hecho ni verdadero ni falso" ( $\mathrm{La}$ carga..., cit., p. 110).

$420 \quad$ Sistema..., cit., v. 1, p. 751-753.

421 Esta constatação é feita por BARBOSA MOREIRA, para quem "muchos miran con sospecha a la admisión de la inversión convencional, en la que veen una ocasión de peligro para la igualdad material, ante la eventualidad de que el contratante económicamente más fuerte imponga al más débil una regulación capaz de privarlo de todas o casi todas sus posibilidades prácticas de defensa. Les leyes que admiten tales convenciones buscan eliminar o atenuar ese inconveniente negándoles validez cuando tornen excesivamente difícil a cualquiera de las partes el ejercicio de su derecho". (La igualdad... cit., p. 70). 
Diante da situação em que o juiz se depara com uma convenção sobre distribuição do ônus da prova que impossibilita ou dificulta que uma parte exerça o seu lídimo direito de ação ou de defesa, e, consequentemente, impeça ou dificulte o seu acesso à tutela jurisdicional pretendida, o deveria fazer? Seria cabível a aplicação da técnica de distribuição dinâmica do ônus da prova?

Mais uma vez, parece-nos que a técnica de distribuição dinâmica do ônus da prova poderia ser invocada, sobretudo se esta dificuldade da parte convencionalmente onerada se revelar em uma desigualdade na capacidade probatória (dificuldade de uma e facilidade da parte contrária).

Contudo, também nessa hipótese o uso da técnica de dinamização não se mostra o mecanismo mais adequado.

Com efeito, apurada a irregularidade na convenção das partes sobre distribuição do ônus da prova, por impor ônus desproporcionais entre as partes, caberá ao juiz simplesmente declarar tal convenção nula, conforme determina o parágrafo único do artigo 333 do Código de Processo Civil, e ordenar a realização das provas pelas partes de acordo com a regra geral e abstrata prevista no caput do mesmo artigo 333 do Código de Processo Civil, ${ }^{422}$ atribuindo a cada uma das partes o ônus de provar as alegações de fato que embasam as suas expectativas pretensões.

\section{Para BARBOSA MOREIRA, se}

[...] o juiz se defronta com determinada convenção acerca da distribuição do ônus da prova e verifica que é indisponível o direito controvertido no processo, deve declará-la nula (CPC, art. 333, parágrafo único, I) e julgar a lide, sendo o caso, à luz das regras legais sobre a matéria. Não há necessidade de prévia decisão que invalide o ato. A nulidade é declarável ex officio.

Somente se, eventualmente, após a anulação da convenção, no curso da instrução probatória, revelar-se uma situação de desigualdade nas capacidades probatórias das partes em relação à determinada alegação de fato, é que se cogitará da aplicação da técnica de distribuição dinâmica do ônus da prova, mas jamais como uma alternativa à anulabilidade da convenção das partes.

422 Convenções..., cit., p. 190. 


\subsection{Dinamização da distribuição do ônus da prova e os meios de prova disponíveis}

Expostas nos itens precedentes deste capítulo algumas hipóteses de flexibilização da distribuição do ônus da prova e sua confrontação com a técnica de distribuição dinâmica do ônus da prova, cumpre-nos, agora, examinar o efetivo campo de incidência da aludida técnica à luz dos meios de prova típicos.

Em relação ao depoimento pessoal, verificamos no item "6.3.3" que o sistema já prevê uma hipótese de presunção legal relativa para punir a parte que se recusa a depor ou simplesmente não comparece à audiência regularmente designada para esse fim. Assim, ainda que se verifique uma desigualdade na capacidade probatória das partes quanto a um fato que somente pode ser provado pelo depoimento pessoal, a técnica adequada a ser utilizada pelo magistrado é a imposição do ônus de depor, sob pena de presunção relativa de confissão do fato controvertido.

Na hipótese de a prova de determinada alegação de fato depender da oitiva de testemunhas, podemos vislumbrar a aplicação da técnica de distribuição dinâmica do ônus da prova, sempre que a testemunha seja conhecida apenas por uma das partes e a alegação a ser provada tenha sido formulada pela parte contrária. Se a testemunha fosse conhecida do juízo, a sua oitiva poderia ser determinada de ofício e ficaria superado o problema.

No caso, porém, de a identidade da testemunha não ter sido revelada, mas a parte interessada na prova testemunhal apresentar elementos convincentes da sua existência, se as circunstâncias revelarem que a prova não pode ser obtida de outra forma senão com a oitiva da testemunha, parece-nos que o juiz poderá aplicar a técnica de dinamização do ônus probatório e impor à parte que tem acesso à testemunha o ônus de provar a situação contrária àquela alegada pela parte que não teve o acesso à testemunha, seja por meio da oitiva da aludida testemunha ou de outros meios que lhe sejam acessíveis.

Vejamos uma situação prática para confirmação da hipótese.

Tício promove ação de reparação de danos contra empresa de coleta de lixo do local onde reside, pleiteando uma indenização por danos materiais decorrentes de estragos 
ocasionados ao seu veículo que estava estacionado na rua, e que durante certa noite foi abalroado por outro veículo, e, segundo o porteiro de um edifício localizado a cerca de 80 metros do local onde o veículo de Tício estava estacionado, logo após ter ouvido o barulho de uma colisão, viu passar um caminhão da empresa de lixo. O porteiro não viu o acidente e apenas presumiu que teria sido ocasionado pelo caminhão de lixo porque foi o único veículo que viu após o barulho da colisão. A empresa de lixo, em sua defesa, não nega que o caminhão tenha passado no local próximo ao momento do acidente, mas nega que a colisão tenha sido ocasionada pelo caminhão. A empresa não concede nenhum tipo de informação quanto a quem era o motorista do caminhão e os outros funcionários que faziam a coleta de lixo. A rua não possui nenhum tipo de monitoramento por vídeo.

Produzida prova pericial a pedido de Tício para tentativa de compreensão da dinâmica do acidente e vistoria das condições dos veículos supostamente envolvidos, embora constatado que o caminhão da empresa tinha algumas avarias, a prova resulta inconclusiva. Solicitada a exibição do livro de ponto para tentar identificar os funcionários envolvidos, a empresa apresenta uma relação com mais de 1.000 funcionários em atividade no momento do acidente e alega ser impossível determinar quais eram os funcionários presentes no local naquele momento.

Diante da situação relatada, a oitiva dos funcionários da empresa de coleta de lixo que trabalhavam no caminhão supostamente envolvido no acidente nos parece essencial ao deslinde da controvérsia e, ainda que a empresa alegue que esses funcionários não são identificáveis, esse argumento não parece muito plausível, pois acredita-se que a empresa tenha algum tipo de controle sobre sua frota e funcionários, até para que não ocorram falhas na área de cobertura da coleta de lixo.

O juiz, sensível a esta última ponderação, além da constatação de avarias no caminhão e do testemunho do porteiro, que indicam a verossimilhança da alegação de Tício, poderia, em nosso entendimento, utilizar a técnica de distribuição dinâmica do ônus da prova no caso e ordenar que a empresa produzisse a prova de que seus funcionários não agiram com culpa e não ocasionaram o acidente, trazendo-os como testemunhas para relatarem o que realmente se passou na noite do acidente, sob pena de, não o fazendo, ser acolhida a pretensão de Tício. 
Com esse exemplo, embora outros pudessem ser invocados, associado a tudo o que foi exposto ao longo da presente dissertação, em especial neste Capítulo 6, podemos concluir que a técnica de distribuição dinâmica do ônus da prova tem um bom campo de atuação quando a prova ensejadora da desigualdade na capacidade probatória for a prova testemunhal, mas não é o único meio de prova em que se aplica à aludida técnica.

Prosseguindo com os demais meios de prova típicos, temos a prova pericial, que também nos parece ser um ambiente propício ao emprego da técnica de distribuição dinâmica do ônus da prova.

Com efeito, exceção feita à prova pericial médica, que possui regramento próprio no Código Civil, com o emprego da presunção relativa como mecanismo de flexibilização da distribuição do ônus da prova, como vimos no item "6.3.2", em relação aos demais tipos de perícia, encontramos diversas situações em que uma das partes poderá invocar o uso da dinamização para a solução do litígio.

Isso se dá porque é no campo do conhecimento técnico-informacional que se verifica mais facilmente a possibilidade de desigualdade na capacidade probatória das partes.

Se por um lado os avanços tecnológicos nos permitem alcançar um conhecimento cada vez mais amplo das coisas, no campo técnico-profissional as pessoas estão se tornando ainda mais especialistas, sendo responsáveis por pequenas frações do todo que compõe a cadeia produtiva. Enquanto no âmbito social temos uma horizontalização do conhecimento (em detrimento da sua profundidade), no âmbito profissional o caminho parece ser inverso.

Entretanto, não apenas a complexidade dos meios produtivos pode ocasionar a necessidade da dinamização do ônus probatório. Certas áreas da ciência alcançaram tal estado da arte que o âmbito de pessoas qualificadas para opinar sobre determinado tema se tornou extremamente restrito, e, se esse conhecimento se faz necessário para demonstração de determinada alegação de fato, mas é detido apenas pela parte contrária (por si ou terceiros), deve-se exigir desta parte a sua demonstração, ainda que pela regra geral e abstrata de distribuição do ônus da prova esta não fosse a parte originalmente onerada. 
O exemplo típico é o da demonstração das mazelas do cigarro, em que as fabricantes são as que melhor podem comprovar os reais efeitos passíveis de ocorrer em virtude do consumo desse produto.

Por fim, entre os meios típicos de prova, temos a inspeção judicial, que nada mais é do que a vistoria de pessoa ou coisa realizada diretamente pelo juiz. Ainda que possa ser requerida pelas partes, é o juiz quem irá produzir a prova, pelas percepções que extrair da pessoa ou coisa inspecionada. Trata-se da expressão máxima dos poderes instrutórios do juiz, que busca no contato direto com a fonte da prova esclarecimentos sobre os fatos alegados pelas partes. Assim, não nos parece haver qualquer respaldo para a aplicação da técnica de distribuição dinâmica do ônus da prova nessa hipótese.

Se a pessoa ou coisa é acessível ao juiz, inexiste razão para qualquer alteração no ônus probatório das partes, pois não se vislumbra uma facilitação da prova na espécie e, mesmo se fosse cogitada uma desigualdade na capacidade probatória das partes, esta estaria suprimida pelo contato do juiz com a pessoa ou coisa objeto da prova.

Diante de tais considerações, podemos restringir o campo de atuação da técnica de distribuição dinâmica do ônus da prova para as alegações de fato que puderem ser provadas por meio de prova testemunhal ou prova pericial apenas, excluída desta última a perícia médica das partes.

\subsection{Distribuição dinâmica do ônus da prova e os modelos de constatação}

A distribuição dinâmica do ônus da prova deve ser confrontada, ainda, com os "modelos de constatação", para que sejam estabelecidos os limites e funções de cada instituto, bem como a ingerência de um sobre o outro, pois, ao certo, ainda que tenham finalidades semelhantes, esses mecanismos não se confundem. ${ }^{423}$

423 Infelizmente, alguns doutrinadores como LUIZ GUILHERME MARINONI (Formação da convicção..., cit., p. 19), ViCEnTE Higino Neto (Ônus da prova..., cit., p. 108-111) e RodRIGO XAVIER LEONARDO (Imposição e inversão do ônus da prova. Rio de Janeiro: Renovar, 2004. p. 175) têm propagado essa confusão entre a técnica dinâmica e os modelos de constatação, como se ambos incidissem na fase de valoração da prova, mas, como veremos, não é possível tal confusão, de sorte que os referidos mecanismos devem ser tratados de maneira distinta e autônoma, podendo, inclusive, coexistir no mesmo processo, porém numa relação casual. 
Para que possamos definir precisamente a área de atuação dessas técnicas, inicialmente precisamos tecer algumas considerações sobre os "modelos de constatação", também denominados "standards probatórios".

Nas palavras de JORDI FERRER BELTRÁN, trata-se de "uma teoria que nos diga quando, ou sob que condições, os elementos de juízo disponíveis são suficientes para que se repute racional aceitar uma proposição como verdadeira no âmbito do raciocínio decisório". 424

Ou seja, trata-se do estabelecimento, no âmbito processual, do grau de convencimento que o juiz deve ter para decidir a causa, que não é mensurável numericamente, mas que admite um escalonamento conforme o objeto do processo e as circunstâncias do caso concreto.

No direito pátrio, um dos precursores no estudo dos "modelos de constatação" foi DANILO KNIJNIK, para quem "representam uma forma de viabilizar não um mecanismo de controle numérico-quantitativo - o que seria, obviamente, irrealizável -, mas uma pauta ou critério à luz do qual o juízo de fato pode ser formado e submetido ao contraditório". 425

Ou ainda, como sintetiza ARTUR CARPES, "servem para orientar o órgão jurisdicional a respeito do grau mínimo de prova para a formação do seu convencimento quanto aos fatos". 426

Como já vimos, o grau de convencimento do juiz sobre as alegações de fato variável e o que os "modelos de constatação" propõem é o estabelecimento prévio, em lei ou pelo próprio juiz, do grau de convencimento que será exigido nas diferentes espécies de demanda para a comprovação dos fatos, podendo ser vislumbrados quatro modelos, quais sejam: a "preponderância de provas" (menor grau de convencimento), a "prova clara e convincente", a "prova acima da dúvida razoável" e a "razoável excludente de qualquer hipótese de inocência" (maior grau de convencimento).

\footnotetext{
$424 \quad$ Prueba y verdad..., cit., p. 78.

425 A prova..., cit., p. 37.

426 Ônus dinâmico..., cit., p. 99.
} 
No processo civil podem ser aplicados os dois primeiros graus, sendo o mais corriqueiro o da "preponderância de provas", incidente nas relações civis patrimoniais. O grau da "prova clara e convincente" é reservado para as ações de natureza não patrimoniais e situações especiais que têm um nítido caráter punitivo (embora sejam ações civis), como as ações civis por ato de improbidade administrativa.

Ocorre que, em determinadas circunstâncias, diante da eventual dificuldade na produção da prova que incumbe às partes, para que não ocorra uma privação indevida do acesso à tutela jurisdicional, o juiz pode admitir uma redução no grau de convencimento exigido e proferir uma sentença calcada em um convencimento de menor grau (em vez de certeza ou probabilidade bastaria a mera verossimilhança), técnica esta denominada de "redução do módulo da prova". ${ }^{427}$

Realizada essa breve nota introdutória sobre os "modelos de constatação" e a possibilidade de redução do módulo da prova, devemos, agora, confrontá-lo com a técnica de distribuição dinâmica do ônus da prova.

A primeira distinção que podemos fazer diz respeito à inexistência de qualquer tipo de gradação na aplicação da técnica dinâmica, que é cabível em ações civis de qualquer espécie, seja qual for sua natureza e/ou a disponibilidade do direito material envolvido. Já os "modelos de constatação", como ficou evidenciado supra, estão diretamente relacionados ao direito material em debate, sofrendo variações conforme sua natureza e disponibilidade.

427 Nesse sentido é a lição de GERHARD WALTER (Libre apreciación de la prueba: investigación acerca del significado, las condiciones y límites del libre convencimiento judicial. Bogotá: Temis, 1985. p. 229-288). Essa técnica também recebe o nome de favor probationes ou prova levior nos países de língua espanhola, e é utilizada quando verificada uma dificuldade probatória in re ipsa, ou seja, inerente ao próprio fato a ser provado, que pode ocorrer em decorrência do tempo decorrido ou por depender de prova ilícita ou indeterminada (PEYRANO, Jorge Walter. Peculiaridades en la materia probatoria. In: ARAZI, Roland et al. La prueba: libro en homenaje del Profesor Santiago Sentís Melendo. La Plata: Platesse, 1996. p. 103). Em tal circunstância, conforme sustenta MUNHOZ SABATÉ, “o juiz deve sair de sua posição estática e fria de espectador para contribuir em favor da parte que mais dificuldades objetivas encontre na produção e estimativa de sua prova" (Técnica probatoria: estudios sobre las dificultades de la prueba en el proceso. Barcelona: Praxis, 1967. p. 146), o que pode se dar com uma valoração diferenciada das provas, examinando melhor os indícios e as presunções, ou dando maior relevância à prova testemunhal, por exemplo. Independentemente da nomenclatura que se adote, o resultado é sempre o mesmo: diante da dificuldade das partes em produzir prova sobre determinada alegação de fato, em vez de se alterar a distribuição do ônus da prova, o juiz pode adotar critérios mais leves de valoração da prova, para formar o seu convencimento com base em um juízo de verossimilhança. 
A segunda diferença entre os institutos está no momento processual de aplicação. A técnica de dinamização da distribuição do ônus da prova atua durante toda a fase instrutória, quando é constatada a desigualdade nas capacidades probatórias das partes, atribuindo o ônus da prova à parte em melhores condições de produzir a prova (função subjetiva do ônus da prova), e também terá pertinência após o seu encerramento, desde que permaneça o estado de dúvida no julgador, mas agora como regra de julgamento para definição do resultado do processo (função objetiva do ônus da prova), desde que, como sustentamos, tenha sido previamente oportunizado à parte, que se tornou onerada, se desincumbir.

Por outro lado, os "modelos de constatação", por seu turno, terão incidência especificamente no momento de valoração da prova, atuando como critério racional de exame e apreciação da prova já produzida, para a formação do convencimento do magistrado, ainda que a definição do modelo aplicável tenha sido realizada previamente. ${ }^{428}$

Ou seja, se imaginarmos uma divisão do processo em três "fases", a partir do saneamento ("instrução probatória", "valoração da prova" e "decisão"), temos que a técnica de distribuição dinâmica do ônus da prova atua na primeira e, eventualmente, na terceira fase, e os modelos de constatação atuam unicamente na segunda fase.

Disso extraímos que as duas técnicas não se confundem e não estão vinculadas em uma relação de causa e efeito, de modo que eventual redução do módulo da prova não

428 Aqui vale a ressalva que o projeto do novo Código de Processo Civil, em seu artigo 368, aboliu a expressão "livremente" contida no artigo 131 do atual Código de Processo Civil, para se referir à valoração dos fatos e das provas e à formação do convencimento do magistrado para julgar. O uso da referida expressão já era criticada por BARBOSA MOREIRA, que sustenta que "livre valoração da prova não significa, é claro, arbítrio judicial na reconstrução dos fatos. A rigor, talvez nem seja próprio aplicar o adjetivo 'livre', consoante não raro se faz, ao convencimento do juiz. O que se pode discutir, e na realidade se tem discutido, com referência a este, é o grau de força persuasiva que, uma vez valorada, deve a prova atingir para justificar a afirmação ou a negação do fato a que ela concerne". (Alguns problemas..., cit., p. 155). Em nosso sentir, a nova redação revela-se mais condizente com o modelo vigente (racional) de valoração das provas e da necessidade de oportunizar sempre o contraditório prévio, como critério de persuasão, haja vista que retira a (falsa) impressão de que o juiz poderia decidir "secundum conscientiam", embora em substância não vislumbremos uma modificação de paradigma. Com ou sem a referência ao "livre" convencimento, o juiz era e continuará vinculado aos elementos probatórios produzidos no processo para decidir, extraindo destes o seu convencimento a partir de regras jurídicas, lógicas e de sua experiência, devendo, necessariamente, expor os motivos que o levaram a decidir de determinada forma (o dever de motivação continua inabalável). O que pode variar, conforme sustentamento no presente item, é o grau ou a intensidade do convencimento necessário para cada tipo de julgamento. 
implica a alteração da distribuição do ônus da prova, assim como o inverso também é verdadeiro.

É certo, ainda, que, independentemente do modelo de constatação adotado, a distribuição dinâmica pode acontecer, desde que presentes os requisitos condicionantes, assim como também poderá ocorrer de o juiz, no momento de valorar as provas, optar por uma redução do módulo da prova aplicável na espécie, de modo que se considere convencido acerca de determinadas alegações de fato a partir de um critério menos "rigoroso" de confirmação.

Quando o juiz se utiliza dessa técnica, extraindo seu convencimento das provas produzidas, a consequência sobre distribuição dinâmica é que serão reduzidos os casos de julgamento fundado na regra de distribuição do ônus da prova, diminuindo, assim, a incidência da dinamização sob o aspecto objetivo do ônus da prova.

Outro ponto de divergência entre as técnicas de dinamização e de redução do módulo da prova é em relação aos requisitos de aplicabilidade. Embora ambos devam ser utilizados quando apurada uma dificuldade na produção da prova no caso concreto, sempre com o objetivo de facilitar a prova e o acesso à tutela jurisdicional, na técnica dinâmica é necessário que ocorra uma desigualdade nas capacidades probatórias das partes (extrema dificuldade/impossibilidade de uma parte e facilidade de outra), enquanto a redução do módulo da prova se dá quando a dificuldade em produzir prova é de ambas, ou seja, tratase de uma prova diabólica tanto para o autor como para o réu, devendo a solução de dar com a valoração da prova, e não com a redistribuição do ônus da prova, pois nenhuma das partes terá capacidade para se desincumbir de tal ônus.

Assim, se a solução da lide puder ocorrer de forma satisfatória com a redução do módulo da prova, o que pode incluir, inclusive, o acolhimento de determinadas presunções simples, sem necessidade da alteração da distribuição do ônus probatório, o juiz deve assim agir, pois será dada uma solução ao conflito e, consequentemente, estarão atendidos os escopos da jurisdição.

Exemplo da aplicação da técnica de redução do módulo da prova, em vez da dinamização da distribuição dos ônus probatórios, pode ser encontrado nas ações de 
reparação de danos promovida por consumidora de pílula anticoncepcional que engravidou em decorrência de falha da fabricação do remédio (cartela com 20 comprimidos em vez de 21). A consumidora comprova que consumia o anticoncepcional, mas não consegue fazer a prova de que adquiriu exatamente do lote com defeito. A prova de que adquiriu do lote defeituoso é impossível para a consumidora, pois não seria dela exigível que guardasse todas as cartelas vazias do remédio. Da mesma forma é impossível à indústria farmacêutica provar que a consumidora consumiu o anticoncepcional de um lote sem defeito. Reduzindo o módulo da prova, é possível inferir como "provável” (ou presumido) que a consumidora tenha adquirido o produto defeituoso, pois consumia com frequência o remédio (indício), e ainda assim engravidou.

De qualquer forma, é inegável que ambas as técnicas têm uma finalidade semelhante, consistente em viabilizar o acesso à tutela jurisdicional mesmo diante de uma situação de dificuldade ou impossibilidade de se desincumbir dos seus respectivos ônus probatórios, atuando de maneira independente e em momentos distintos, conforme as peculiaridades do caso concreto assim exigem. 


\section{CONCLUSÕES}

Diante do exame dos aspectos dogmático e empírico da técnica de distribuição dinâmica do ônus do prova, podemos extrair algumas conclusões a respeito do instituto, sem prejuízo de outras que possam ter sido expostas ao longo da presente dissertação, quais sejam:

O ônus da prova exerce, necessariamente, uma dupla função no processo, uma direcionada às partes (função subjetiva), para estruturação da prova, e outra, ao juiz (função objetiva), determinando como este deverá julgar em caso de, mesmo após a instrução probatória, persistir o estado de dúvida.

A distribuição do ônus da prova tem como principal fundamento o interesse das partes, a quem se atribui o ônus de provar as alegações de fato que fundamentam as suas respectivas pretensões, como condição essencial para que possam convencer o juiz de sua veraciadade e, assim, obter êxito no processo.

Em um modelo de igualdade formal, a regra estática de distribuição do ônus da prova estabelecida no artigo 333 do Código de Processo Civil, se bem compreendido o seu significado, é capaz de dar uma solução satisfatória aos jurisdicionados e conforme os escopos da jurisdição.

O processo civil moderno, contudo, deve assegurar a igualdade substancial das partes e, sempre que houver desigualdade, cumpre ao juiz dar tratamento desigual às partes, como medida de justiça.

Quando a desigualdade entre as partes encontra-se nas respectivas capacidades probatórias, sendo a realização da prova para a parte onerada extremamente difícil ou mesmo impossível, e, por seu turno, a parte contrária demonstrar certa facilidade da produção de prova da alegação do fato contrário, seja por dispor das informações pertinentes ao objeto da prova, de conhecimentos técnicos específicos ou mesmo por dispor dos meios de prova, o juiz pode se valer da técnica de distribuição dinâmica do ônus da prova, deslocando o ônus probatório de uma parte à outra, de modo a se (re)estabelecer um equilíbrio de forças no processo. 
Para a aplicação da distribuição dinâmica do ônus da prova, o magistrado deve dar especial atenção à função subjetiva do ônus da prova, pois somente é possível se cogitar de uma redefinição dos ônus probatórios das partes, se a elas for oportunizada a desincumbência, sob pena de ofensa ao contraditório e à ampla defesa.

A técnica de distribuição dinâmica do ônus da prova é uma espécie subsidiária de atribuição de ônus probatórios às partes, aplicável em situações excepcionais em que o modelo abstrato e estático se revelou incapaz de manter a igualdade substancial entre as partes litigantes, assim como os demais mecanismos de flexibilização ou de obtenção da prova, como as presunções e os poderes instrutórios do juiz, não puderem dar uma solução satisfatória, seja com a dispensa da prova, a advertência judicial prévia para sua a realização ou mesmo sua produção de ofício pelo juiz.

Com efeito, se a situação concreta revelar a possibilidade de se realizar a prova por outros meios que não a simples distribuição do ônus da prova conforme a regra geral, deve o magistrado dar preferência a estes instrumentos.

Somente quando não houver outro caminho para obtenção da prova é que deverá se aplicada a técnica de distribuição dinâmica do ônus da prova, desde que presentes os requisitos, o que revela, mais uma vez, o seu caráter excepcional e seu campo de incidência limitado, o que não lhe retira sua pertinência em um sistema processual moderno, calcado na igualdade substancial, no dever de colaboração e de entrega da tutela jurisdicional justa e efetiva, pois a sua utilização permitirá uma otimização da instrução probatória e da descoberta dos fatos, aumentando a possibilidade de se encontrar, em casos específicos e particulares, uma solução conforme o que rege o direito material aplicável à espécie.

Uma vez aplicada, nos limites dos meios de prova típicos que a admitem (testemunhas e perícias), a técnica dinâmica implica o deslocamento de parte dos ônus probatórios de uma parte para o seu adversário, que estará incumbido da prova da alegação de fato contrária à alegação originalmente formulada pela parte onerada.

Esta constatação demonstra a incorreção da expressão "inversão" do ônus da prova, comumente empregada no direito pátrio em decorrência da redação defeituosa do 
Código de Defesa do Consumidor, pois não se trata de uma mera alteração subjetiva do ônus (do autor para o réu ou do réu para o autor), mas de uma alteração do ônus da prova e do próprio objeto da prova.

Embora a técnica dinâmica ainda não esteja expressamente prevista no ordenamento jurídico pátrio, exceção feita nas ações que envolvem relação de consumo, em face da disposição contida no inciso VIII do artigo $6 .^{\circ}$ do Código de Defesa do Consumidor que prevê esse mecanismo, o que deve ficar superado com a promulgação do novo Código de Processo Civil, uma interpretação sistêmica dos princípios e garantias constitucionais, associados às regras instrumentais que asseguram a isonomia, o contraditório e a colaboração, nos leva a acreditar que a técnica de distribuição dinâmica do ônus da prova deve ser admitida à luz do direito vigente, encontrando, ainda, respaldo doutrinário e jurisprudencial para sua imediata aplicabilidade.

Ainda que a técnica de dinamização do ônus probatório tenha um campo reduzido de incidência, atuando sempre de forma subsidiária e desde que preenchidos os requisitos, além de limitados os meios de prova típicos autorizadores da sua aplicação, entendemos que se trata de um mecanismo relevante para a adequada solução de determinadas demandas, principalmente as que envolvem direito do consumidor, por proporcionar um reequilíbrio na capacidade probatória das partes e por permitir que sejam trazidos à tona elementos de prova que podem ser determinantes para a justa solução do conflito.

Assim, se bem aplicada, a técnica de distribuição dinâmica do ônus da prova é um importante instrumento de fomentação da atividade probatória, que permite uma aproximação do julgador à realidade do caso concreto, suprimindo eventuais desigualdades, de modo a permitir, antes de tudo, o acesso ao Poder Judiciário, muitas vezes inviabilizado pela carga probatória que pesa sobre determinada parte, bem como um julgamento em maior consonância com os efeitos pretendidos pela regra de direito material violada, e, portanto, a concessão da tutela jurisdicional de maneira mais justa e segura. 


\section{REFERÊNCIAS BIBLIOGRÁFICAS}

ALVIM, José Manoel de Arruda. Manual de direito processual civil. 10. ed. São Paulo: Revista dos Tribunais, 2006. v. 2.

AMARAl SANTOS, Moacyr. Comentários ao Código de Processo Civil. 4. ed. Rio de Janeiro: Forense, 1988. v. 4.

—. Primeiras linhas de direito processual civil. 18. ed. São Paulo: Saraiva, 1997. 3 v. —. Prova judiciária no cível e comercial. 3. ed. São Paulo: Max Limonad, 1961. 5 v. AMENDOEIRA JÚNIOR, Sidnei. Poderes do juiz e tutela jurisdicional: a utilização racional dos poderes do juiz como forma de obtenção da tutela jurisdicional efetiva, justa e tempestiva. São Paulo: Atlas, 2006.

ARAUJO, Henrique. A matéria de facto no processo civil (da petição ao julgamento). Disponível em: <http://www.trp.pt/ficheiros/estudos/henriquearaujo_materiafacto processocivil.pdf>.

ARAZI, Roland et al. La prueba: libro en homenaje del Profesor Santiago Sentís Melendo. La Plata: Platesse, 1996.

—. La prueba en el proceso civil. 2. ed. Buenos Aires: La Rocca, 1998.

ARENHART, Sérgio Cruz. Ônus da prova e sua modificação no processo civil brasileiro. Revista Jurídica, Porto Alegre: Notadez, v. 54, n. 343, maio 2006.

AZEVEDO, Antonio Danilo Moura de. A aplicabilidade da teoria dinâmica de distribuição do ônus da prova no processo civil. Revista Jurídica Unijus, Uberaba: Universidade de Uberaba, v. 11, n. 14, maio 2008.

BADARÓ, Gustavo Henrique Righi Ivahy. O ônus da prova no processo penal, São Paulo: Revista dos Tribunais, 2003.

- O álibi do acusado e o in dubio pro reo no acórdão da Ação Penal 470/MG. Revista dos Tribunais, São Paulo: RT, v. 102, n. 933, jul. 2013.

BARBOSA, Rafael Vinheiro Monteiro. O ônus da prova no direito processual civil e a sua inversão - a visão do STJ. Revista de Processo. São Paulo: RT, v. 39, n. 233, jul. 2014.

BARBOSA MOREIRA, José Carlos. Julgamento e ônus da prova. Temas de direito processual: segunda série. São Paulo: Saraiva, 1980.

- Convenções das partes sobre matéria processual. Revista de Processo, São Paulo: RT, v. 9, n. 33, jan. 1984.

—. O juiz e a prova. Revista de Processo. São Paulo: Revista dos Tribunais, v. 9, n. 35, abr.-jun. 1984. 
A função social do processo civil moderno e o papel do juiz e das partes na direção e na instrução do processo. Revista de Processo, São Paulo: RT, v. 10, n. 37, jan. 1985.

As presunções e a prova. Temas de direito processual civil: primeira série. 2. ed. São Paulo: Saraiva, 1988.

A garantia do contraditório na atividade de instrução. Revista de Processo, São Paulo: RT, v. 9, n. 35, abr.-jun. 1984.

—. O processo civil hoje: um Congresso da Associação Internacional de Direito Processual. Reflexões sobre direito e sobre processo. Rio de Janeiro, 1992.

_. Efetividade do processo e técnica processual. Temas de direito processual civil: sexta série, São Paulo: Saraiva, 1997.

O problema da "divisão do trabalho" entre juiz e partes: aspectos terminológicos. Temas de Direito Processual: quarta série. São Paulo: Saraiva, 1989.

—. Os poderes do juiz na direção e na instrução do processo. Temas de direito processual: quarta série. São Paulo: Saraiva, 1989.

—. La igualdad de las partes en el proceso civil. Temas de Direito Processual: quarta série. São Paulo: Saraiva, 1989.

Alguns problemas atuais da prova civil. Temas de Direito Processual: quarta série. São Paulo: Saraiva, 1989.

- O futuro da justiça: alguns mitos. Revista de Processo. São Paulo: Revista dos Tribunais, v. 26, n. 102, abril, 2001.

—. Anotações sobre o título "Da prova" do novo Código Civil. RTDC: Revista Trimestral de Direito Civil. Rio de Janeiro: Padma, v.6, n.22, abr./jun., 2005.

- Reformas processuais e poderes do juiz. Temas de direito processual civil: nona série. São Paulo: Saraiva, 2004.

—. O processo, as partes e a sociedade. Revista de Processo. São Paulo: RT, v. 30, n. 125, jul. 2005.

BARBOSA, Rui. Oração aos moços. Disponível em: <http://www.casaruibarbosa.gov.br/ dados/doc/artigos/rui_barbosa/fcrb_RuiBarbosa_Oracao_aos_mocos.pdf >.

BAZZANEZE, Thaís. Distribuição dinâmica dos ônus probatórios: análise à luz do devido processo legal e do acesso à justiça. Revista de Processo, São Paulo: RT, v. 37, n. 205, mar. 2012.

BEDAQUE, José Roberto dos Santos. Direito e processo. 2. ed. São Paulo: Malheiros, 1997. 
—. Efetividade do processo e técnica processual. 2. ed. São Paulo: Malheiros, 2007.

—. Garantias da amplitude de produção probatória. In: CRUZ E TUCCI, José Rogério (Coord.). Garantias constitucionais do processo civil. São Paulo: RT, 1999.

—. Poderes instrutórios do juiz. 5. ed. São Paulo: RT, 2011.

BELTRÁN, Jordi Ferrer. Prueba y verdad en el derecho. 2. ed. Madrid: Marcial Pons, 2005 .

BENTHAM, Jeremy. Tratado de las pruebas judiciales. Tradução Don J. G. de Castro. Madrid: Tomas Jordan, 1835. 2 t.

BETTI, Emilio. Diritto processuale civile italiano. 2. ed. Roma: Società Editrice del Foro Italiano, 1936.

BONNIER, Edouard. Tratado teorico y practico de la prueba en derecho civil y penal. Tradução Don J. V. Caravantes. Madrid: Reus, 1929.

BONICIO, Marcelo José Magalhães. Ensaio sobre o dever de colaboração das partes previsto no projeto do novo código de processo civil brasileiro. Revista de Processo, São Paulo: RT, v. 35, n. 190, dez. 2010.

BORTOWSKI, Marco Aurelio Moreira. A carga probatória segundo a doutrina e o Código de Defesa do Consumidor. Revista de Direito do Consumidor, São Paulo: RT, n. 7, jul.-set. 1993.

BRAGA, Sidney da Silva. Iniciativa probatória do juiz no processo civil. São Paulo: Saraiva, 2004.

BUENO, Cassio Scarpinella. Curso sistematizado de direito processual civil: procedimento comum: ordinário e sumário. 7. ed. São Paulo: Saraiva, 2014. v. 2, t. I.

BÜLOW, Oskar von. La teoría de las excepciones procesales y los presupuestos procesales. Tradução M. A. R. Lichtschein. Buenos Aires: EJEA, 1964.

BUZAID, Alfredo. Estudos de direito. São Paulo: Saraiva, 1972. v. 1.

CABRAL, Antonio do Passo. Il principio del contraddittorio come diritto d'influenza e dovere di dibattito. Rivista di Diritto Processuale, Padova, v. 60, n. 2, apr.-giug. 2005.

—. O contraditório como dever e a boa-fé processual objetiva. Revista de Processo, São Paulo: RT, v. 30, n. 126, ago. 2005.

CABRERA, Juan Trujillo. La carga dinámica de la prueba. Bogotá: Leyer, 2006.

CALAMANDREI, Piero. Instituciones de derecho procesal civil. Tradução S. S. Melendo. Buenos Aires: Depalma, 1943. v. 1.

—. Studi sul processo civile. Padova: Cedam, 1934. v. 3.

—. Padova: Cedam, 1947. v. 5. 
Padova: Cedam, 1957. v. 6.

CALMON DE PASSOS, José Joaquim. Instrumentalidade do processo e devido processo legal. Revista Forense, Rio de Janeiro: Forense, v. 96, n. 351, jul.-set. 2000.

CÂMARA, Alexandre Freitas. Doenças preexistentes e ônus da prova: o problema da prova diabólica e uma possível solução. Revista Dialética de Direito Processual, São Paulo: Dialética, v. 31, out. 2005.

CAMBI, Eduardo. Direito constitucional à prova no processo civil. São Paulo: RT, 2001.

—. Divergência jurisprudencial: inversão do ônus da prova e o ônus de antecipar o pagamento dos honorários periciais. Revista dos Tribunais, São Paulo: RT, v. 804, out. 2002.

Curso de direito probatório. Curitiba: Juruá, 2014.

CANOTILHO, J.J. Gomes. Direito constitucional e teoria da constituição. 4. ed. Coimbra: Almedina, 2000.

CAPPELLETTI, Mauro. El testimonio de la parte en el sistema de la oralidad: contribución a la teoría de la utilización probatoria del saber de las partes en el proceso civil. Tradução S. S. Melendo. La Plata: Platense, 2002. v. 1.

; GARTH, Bryant. Acesso à justiça. Tradução E. G. Northfleet. Porto Alegre: Fabris, 1988.

CARDOSO, Oscar Valente. Peculiaridades da inversão do ônus da prova no CDC: teoria dinâmica, hipossuficiência e extratos bancários. Revista Dialética de Direito Processual, São Paulo: Dialética, n. 102, set. 2011.

CARNELUTTI, Francesco. Instituciones del proceso civil. Tradução J. Guasp. Buenos Aires: E.J.E.A, 1959, 3 v.

—. La prueba civil. Tradução N. A. Z. Castillo. Buenos Aires: Ediciones Arayú, 1955.

Sistema de diritto processuale civile. Padova: Cedam, 1936. v. 1.

CARPES, Artur Thampsen. A distribuição dinâmica do ônus da prova no formalismovalorativo. Revista da Ajuris, Porto Alegre: Ajuris v. 33, n. 104, dez. 2006.

—. A nova relação do caput do art. 522 do CPC (Lei 11.187/2005) e o recurso cabível da decisão acerca da dinamização dos ônus probatórios. Revista de Processo, São Paulo: RT, v. 35, n. 179, jan. 2010.

Onus dinâmico da prova. Porto Alegre: Livraria do Advogado, 2010.

CHIOVENDA, Giuseppe. Instituições de direito processual civil. Tradução J. G. Menegale. 2. ed. São Paulo: Saraiva, 1965, 2 v. 
_. Principios de derecho procesal civil. Madrid: Reus, 1922. 2 v.

CARVALHO, Fabiano; BARIONI, Rodrigo (Coord.). Aspectos processuais do Código de Defesa do Consumidor. São Paulo: RT, 2008.

CARVALHO, José Carlos Maldonado de. A inversão do ônus da prova e a inversão do encargo decorrente sob a ótica do direito do consumidor. Revista de Direito do Consumidor, São Paulo: RT, v. 12, n. 46, abr.-jun. 2003.

CINTRA, Antônio Carlos Araújo. Comentários ao Código de Processo Civil. 3. ed. Rio de Janeiro: Forense, 2008.

_- GRINOVER, Ada Pellegrini; DINAMARCO, Cândido Rangel. Teoria geral do processo. 17. ed. São Paulo: Malheiros, 2001.

COITINHO, Jair Pereira. Prova e dever de colaboração: o juízo de fato e a conduta dos sujeitos principais no processo civil brasileiro contemporâneo. 2007. Dissertação (Mestrado em Direito) - Pontifícia Universidade Católica do Rio Grande do Sul, Porto Alegre.

COMOGLIO, Luigi Paolo. Garanzie costituzionali e "giusto processo" (modelli a confronto). Revista de Processo, São Paulo: RT, n. 90, abr. 1998.

- Le prove civili. 3. ed. Torino: UTET, 2010.

—; FERRI, Corrado; TARUFFO, Michele. Lezioni sul processo civile: Il processo ordinario di cognizione. Bolonha: Il Mulino, 2006. t. I, v. 2.

COMPARATO, Fábio Konder. A proteção do consumidor. Revista de Direito Mercantil, Industrial, Econômico e Financeiro, São Paulo: RT, n. 15, 1974.

COUTO, Camilo José D’ávila. Dinamização do ônus da prova: teoria e prática. Tese (Doutorado em Direito) - Faculdade de Direito, Universidade de São Paulo, São Paulo, 2011.

COUTURE, Eduardo J. Introdução ao estudo do processo civil. Tradução M. V. Russomano. 3. ed. Rio de Janeiro: José Konfino, 1951.

CREMASCO, Suzana Santi. A distribuição dinâmica do ônus da prova. Rio de Janeiro: GZ, 2009.

CRUZ E TUCCI, José Rogério. Tempo e processo: uma análise empírica das repercussões do tempo na fenomenologia processual (civil e penal). São Paulo: RT, 1997.

CUNHA, Leonardo Carneiro da. O processo civil no estado constitucional e os fundamentos do projeto do novo Código de Processo Civil brasileiro. Revista de Processo, São Paulo: RT, n. 209, jul. 2012. 
DALL'AGNOL JUNIOR, Antonio Janyr. Distribuição dinâmica dos ônus probatórios. Revista dos Tribunais, São Paulo: RT, n. 788, jun. 2001.

DELL'ISOLA, Carmela. O ônus da prova e sua inversão no processo civil. 2001. Dissertação (Mestrado em Direito) - Faculdade de Direito, Universidade de São Paulo, São Paulo.

DENTI, Vittorio. L'inversione dell'onere della prova: rilievi introduttivi. Rivista Trimestrale di Diritto e Procedura Civile, Milano: Giuffrè, v. 46, n. 3, sett. 1992.

DIDIER JÚNIOR, Fredie. Os três modelos de direito processual: inquisitivo, dispositivo e cooperativo. Revista de Processo. São Paulo: Revista dos Tribunais, v. 36, n. 198, ago. 2011.

; MAZZEI, Rodrigo (org.). Prova, Exame Médico e Presunção: O art. 232 do Código Civil. Salvador: JusPodivm, 2006.

; NOGUEIRA, Pedro Henrique Pedrosa. Teoria dos fatos jurídicos processuais. 2. ed. Salvador: JusPodivm, 2013.

DINAMARCO, Candido Rangel. A instrumentalidade do processo. 14. ed. São Paulo: Malheiros, 2009.

—. Fundamentos do processo civil moderno. 2. ed. São Paulo: RT, 1987, v. 1.

—. Instituições de direito processual civil. São Paulo: Malheiros, 2001. v. 1.

—. 2. ed. São Paulo: Malheiros, 2002. v. 2 e 3.

DOWNES, Stephen. Guide to the logical fallacies. Disponível em: <http://www. onegoodmove.org/fallacy/define_index.htm>.

ECHANDÍA, Hernando Devis. Teoría general de la prueba judicial. 6. ed. Buenos Aires: Zavalia, 1974. 2 t.

EL CLARO, Roberto Benghi. Direção material do processo. 2009. Tese (Doutorado em Direito) - Faculdade de Direito, Universidade de São Paulo, São Paulo.

FARIA, S. Soares de. Principaes theorias relativas ao onus probandi. São Paulo: RT, 1936.

FERMANN, Rodrigo Papaléo. Teoria da distribuição dinâmica do ônus da prova. In: MITIDIERO, Daniel (Org.). O processo civil no estado constitucional. Salvador: JusPodivm, 2012.

FERREIRA, Aurélio Buarque de Holanda. Novo dicionário eletrônico Aurélio. 3. ed. São Paulo: Positivo, 2004. CD-ROM.

FIALHO, António José. A petição inicial. Disponível em: <http://www.fd.unl.pt/docentes _docs/ma/mfg_ma_8888.pdf $>$. 
GAJARDONI, Fernando da Fonseca. Flexibilização procedimental: um enfoque para o estudo do procedimento em matéria processual, de acordo com as recentes reformas do CPC. São Paulo: Atlas, 2008

GARCIA, André Almeida. A distribuição do ônus da prova e sua inversão judicial no sistema processual vigente e no projetado. Revista de Processo, São Paulo: RT, v. 37, n. 208, jun. 2012.

GIDI, Antonio. Aspectos da inversão do ônus da prova no Código de Defesa do Consumidor. Revista de Direito do Consumidor, São Paulo: RT, n. 13, jan.-mar. 1995.

GIORGIS, José Carlos Teixeira. A prova dinâmica no direito de família. In: MILHORANZA, Mariângela Guerreiro; PEREIRA, Sérgio Gischkow (Coord.). Direito contemporâneo de família e das sucessões: estudos jurídicos em homenagem aos 20 anos de docência do prof. Rolf Madaleno. Rio de Janeiro: GZ, 2009.

GODINHO, Robson Renault. A distribuição do ônus da prova na perspectiva dos direitos fundamentais. Revista da Ajuris, Porto Alegre: Ajuris, v. 35, n. 109, mar. 2008.

GOLDSCHMIDT, James. Derecho procesal civil. Tradução L. P. Castro. Barcelona: Labor, 1936.

GRANDE, Maximiliano García. Cargas probatorias dinámicas: ni nuevas, ni argentinas, ni aplicables. Disponível em: <http://www.academiadederecho.org/biblioteca/biblio_ display_cont.cgi? $\mathrm{wAccion}=$ down\&wid_cont=2705\&wFile=Cargas_probatorias_dinamicas _Maxim_G_Grande.pdf>.

—. Las cargas probatorias dinámicas: inaplicabilidad. Buenos Aires: Juris, 2005.

GRASSO, Eduardo. La collaborazione nel processo civile. Rivista di Diritto Processuale, Padova: Cedam, v. 21 (II serie), 1966.

GRINOVER, Ada Pellegrini et al. Código brasileiro de Defesa do Consumidor comentado pelos autores do anteprojeto. 6. ed. Rio de Janeiro: Forense, 2000.

HIGINO NETO, Vicente. Ônus da prova: teorias da redução do módulo da prova e das provas dinâmicas e compartilhadas. Curitiba: Juruá, 2010.

HOFFMAN, Paulo. Inversão do ônus da prova prevista no Código de Defesa do Consumidor - Critério de julgamento (sob a ótica do juiz) e critério de procedimento (para o fornecedor). In: CARVALHO, Fabiano; BARIONI, Rodrigo (Coord.). Aspectos processuais do Código de Defesa do Consumidor. São Paulo: RT, 2008.

KNIJNIK, Danilo. A prova nos juízos cível, penal e tributário. Rio de Janeiro: Forense, 2007. 
As (perigosíssimas) doutrinas do "ônus dinâmico da prova" e a da "situação de senso comum" como instrumentos para assegurar o acesso à justiça e superar a probatio diabolica. In: FUX, Luiz; NERY JUNIOR, Nelson; WAMBIER, Teresa Arruda Alvim (Coord.). Processo e Constituição: estudos em homenagem ao professor José Carlos Barbosa Moreira. São Paulo: RT, 2006.

(Coord.). Prova judiciária: estudos sobre o novo direito probatório. Porto Alegre: Livraria do Advogado, 2007.

LACERDA, Galeno. Despacho saneador. Porto Alegre: Sulina, 1953.

LAZARI, Rafael José Nadim de; SOUZA, Gelson Amaro de. Reflexões sobre a perspectiva de uma distribuição dinâmica do ônus da prova: análise da viabilidade. Revista Dialética de Direito Processual, São Paulo: Dialética, n. 99, jun. 2011.

LEONARDO, Rodrigo Xavier. Imposição e inversão do ônus da prova. Rio de Janeiro: Renovar, 2004.

LEONEL, Ricardo de Barros. Manual do processo coletivo. São Paulo: RT, 2002.

LESSONA, Carlo. Teoría general de la prueba en derecho civil. Tradução E. A. de Paz. Madrid: Reus, 1906. v. 1.

LIEBMAN, Enrico Tullio. Manual de direito processual civil. Tradução C. R. Dinamarco. Rio de Janeiro: Forense, 1984, v. 1.

LIMA, Cíntia Rosa Pereira de; FANECO, Lívia Carvalho da Silva. Inversão do ônus da prova no $\mathrm{CDC}$ e a inversão procedimental no projeto de novo $\mathrm{CPC}$ : distinção entre institutos afins. Revista de Direito do Consumidor, São Paulo: RT, v. 23, n. 91, jan. 2014. LOPES, João Batista. A prova no direito processual civil. 2. ed. São Paulo: RT, 2002.

—. Efetividade da tutela jurisdicional à luz da constitucionalização do processo civil. Revista de Processo, São Paulo: RT, n. 116, jul. 2004.

. Ônus da prova e teoria das cargas dinâmicas no novo Código de Processo Civil. Revista de Processo, São Paulo: RT, v. 37, n. 204, fev. 2012.

— teoria das cargas dinâmicas. In: MOREIRA, Alberto Camiña; ALVAREZ, Anselmo Prieto; BRUSCHI, Gilberto Gomes (Coord.). Panorama atual das tutelas individual e coletiva: estudos em homenagem ao professor Sérgio Shimura. São Paulo: Saraiva, 2011.

LOPES, Maria Elizabeth de Castro. Ativismo judicial e ônus da prova no processo civil. Revista do Instituto dos Advogados de São Paulo, São Paulo, v. 10, n. 19, jan.-jun. 2007. 
LUCON, Paulo Henrique dos Santos; COSTA, Guilherme Recena. Formalismo processual e dinamização do ônus da prova. In: MITIDIERO, Daniel; AMARAL, Guilherme Rizzo (Coord.); FEIJÓ, Maria Angélica Echer Ferreira (Org.). Processo civil: estudos em homenagem ao professor doutor Carlos Alberto Álvaro de Oliveira. São Paulo: Atlas, 2012.

MACÊDO, Lucas Buril de; PEIXOTO, Ravi Medeiros. Ônus da prova e sua dinamização. Salvador: JusPodivm, 2014.

MACHADO, Antônio Montalvão; PIMENTA, Paulo. O novo processo civil. 4. ed. Coimbra: Almedina, 2002.

MACHADO, Marcelo Pacheco. Ônus estático, ônus dinâmico e inversão do ônus da prova: análise crítica do Projeto de novo Código de Processo Civil. Revista de Processo, São Paulo: RT, v. 37, n. 208, jun. 2012.

MALATESTA, Nicola Framarino Dei. A lógica das provas em matéria criminal. Tradução A. A. Correia. São Paulo: Saraiva, 1960. v. 1.

MARINONI, Luiz Guilherme. Formação da convicção e inversão do ônus da prova segundo as peculiaridades do caso concreto. Revista dos Tribunais, São Paulo: RT, v. 96, n. 862, agosto, 2007.

—. Técnica processual e tutela dos direitos. São Paulo: Revista dos Tribunais, 2004.

- ; MITIDIERO, Daniel. O Projeto do CPC: crítica e propostas. São Paulo: RT, 2010.

; ARENHART, Sérgio Cruz. Comentários ao Código de Processo Civil. 2. ed. São Paulo: RT, 2005, v. 5.

— — Prova. São Paulo: RT, 2009.

MATOS, Cecília. Ônus da prova no código de defesa do consumidor. Dissertação (Mestrado em Direito) - Faculdade de Direito, Universidade de São Paulo, São Paulo.

—. O ônus da prova no Código de Defesa do Consumidor. Revista de Direito do Consumidor, São Paulo: RT, n. 11, jul.-set. 1994.

MEDEIROS, Nelson de Miranda. O fato impeditivo e o ônus de prová-lo: ônus de prova de negativa. Revista do Tribunal Regional do Trabalho da 2. ${ }^{a}$ Região. São Paulo: LTr, n. 4, 1979.

MENEZES CORDEIRO, António Manuel da Rocha e. Da boa-fé no direito civil. 2. ed. Coimbra: Almedina, 2001.

MELENDO, Santiago Sentis. Desarrollo del proceso: deberes del juez y cargas de las partes. Boletín mexicano de derecho comparado, n. 24, 1975. 
MICHELLI, Gian Antonio. La carga de la prueba. Tradução S. S. Melendo. Bogotá: Temis, 2004.

MITIDIERO, Daniel. Colaboração no processo civil: pressupostos sociais, lógicos e éticos. 2. ed. São Paulo: RT, 2011.

—. Processo justo, colaboração e ônus da prova. Revista do Tribunal Superior do Trabalho, Rio de Janeiro, v. 78, n. 1, jan.-mar. 2012.

. Antecipação da tutela: da tutela cautelar à técnica antecipatória. 2. ed. São Paulo: RT, 2014.

MORAES, Denise Maria Rodríguez. A dinamização da regra de distribuição do ônus da prova como instrumento de busca da verdade e de efetivação da justiça. Revista de Processo. São Paulo: Revista dos Tribunais, v. 38, n. 226, dezembro, 2013.

MORAES, Voltaire de Lima. Anotações sobre o ônus da prova no Código de Processo Civil e no Código de Defesa do Consumidor. Revista de Direito do Consumidor, São Paulo: RT, n. 31, jul.-set. 1999.

MOREIRA, Carlos Roberto Barbosa. Inversão do ônus da prova e defesa do consumidor (considerações adicionais). Revista Forense, Rio de Janeiro: Forense v. 96, n. 351, jul.-set. 2000.

—. Notas sobre a inversão do ônus da prova em benefício do consumidor. Revista de Direito do Consumidor, São Paulo: RT, n. 22, abr.-jun. 1997.

—. Restricciones a la prueba en la Constitución Brasileña. Revista de Processo, São Paulo: RT, v. 21, n. 82, abr.-jun. 1996.

MORELLO, Augusto Mario (Coord.). Las responsabilidades profesionales: Libro al Dr. Luis O. Andorno. La Plata: LEP, 1992.

—. La prueba: tendencias modernas. Buenos Aires: Abeledo Perrot, 2001.

MUNHOZ SABATÉ, Luis. Técnica probatoria: estudios sobre las dificultades de la prueba en el proceso. Barcelona: Praxis, 1967.

NERY JUNIOR, Nelson. Aspectos do processo civil no Código de Defesa do Consumidor. Revista de Direito do Consumidor, São Paulo: RT, n. 1, mar. 1992.

—. Princípios do processo civil na Constituição Federal. 5. ed. São Paulo: RT, 1999.

NOGUEIRA, Pedro Henrique Pedrosa. A inversão do ônus da prova no Código de Defesa do Consumidor como técnica de distribuição dinâmica da carga probatória. Revista Dialética de Direito Processual, São Paulo: Dialética, n. 75, jun. 2009.

NOGUEIRA, Tânia Lis Tizzoni. A prova no direito do consumidor. Curitiba: Juruá, 2001. 
OLIVEIRA, Carlos Alberto Alvaro de. Do formalismo no processo civil: proposta de um formalismo-valorativo. 4. ed. São Paulo: Saraiva, 2010.

OLIVEIRA, Vivian von Hertwig Fernandes de. A distribuição do ônus da prova no processo civil brasileiro: a teoria da distribuição dinâmica. Revista de Processo, São Paulo: RT, v. 39, n. 231, maio 2014.

PACÍFICO, Luiz Eduardo Boaventura. Direitos básicos do consumidor: a facilitação da defesa dos consumidores e a inversão do onus da prova. Revista de Direito do Consumidor. São Paulo, n. 10, abr./jun., 1994.

—. O ônus da prova. 2. ed. São Paulo: RT, 2011.

PAVANINI, Giovanni. Contributo allo studio del giudizio civile di rinvio. Padova: Milani, 1937.

PICÓ I JUNOY, Joan; ABEL LLUCH, Xavier (Dir.). Objeto y carga de la prueba civil. Barcelona: Bosch, 2007.

PEIXOTO, Ravi Medeiros. Rumo à construção de um processo cooperativo. Revista de Processo, São Paulo: RT, n. 219, maio 2013

PELEJA JÚNIOR, Antônio Veloso. Ativismo judicial e ônus da prova: a teoria da distribuição dinâmica. Revista Jurídica do Ministério Público de Mato Grosso, Cuiabá: Entrelinhas, v. 4, n. 6, jan.-jun. 2009.

PEYRANO, Jorge Walter (Dir.); WHITE, Inés Lépori (Coord.). Cargas probatórias dinamicas. Santa Fé: Rubinzal-Culzoni, 2008.

PONTES DE MIRANDA, Francisco Cavalcanti. Comentários ao Código de Processo Civil. 4. ed. Rio de Janeiro: Forense, 1995. t. I.

- 3. ed. Rio de Janeiro: Forense, 1997. t. IV.

PROTO PISANI, Andrea. Lezioni di diritto processuale civile. 4. ed. Napoli: Jovene, 2002. PUOLI, José Carlos Baptista. Os poderes do juiz e as reformas da lei processual civil brasileira. São Paulo: Juarez de Oliveira, 2002.

QUEIJO, Maria Elizabeth. $O$ direito de não produzir prova contra si mesmo (o princípio 'nemo tenetur se detegere' e suas decorrências no processo penal). São Paulo: Saraiva, 2003 .

RANGEL, Rui Manuel de Freitas. O ónus da prova no processo civil. 1. ed. Coimbra: Almedina, 2000.

REDENTI, Enrico. Profili pratici del diritto processuale civile. Milano: Giuffrè, 1938.

REDONDO, Bruno Garcia. Distribuição dinâmica do ônus da prova: breves apontamentos. Revista Dialética de Direito Processual, São Paulo: Dialética, n. 93, dez. 
—. Ônus da prova e distribuição dinâmica: lineamentos atuais. In: MOREIRA, Alberto Camiña; ALVAREZ, Anselmo Prieto; BRUSCHI, Gilberto Gomes (Coord.). Panorama atual das tutelas individual e coletiva: estudos em homenagem ao professor Sérgio Shimura. São Paulo: Saraiva, 2011.

RIBEIRO, Débora de Oliveira. Inversão do ônus da prova no código de defesa do consumidor. Dissertação (Mestrado em Direito) - Faculdade de Direito, Universidade de São Paulo, São Paulo, 2005.

RIBEIRO, Flávia Pereira. A regulamentação da teoria da carga dinâmica das provas. In: SILVA, Jose Anchieta da (Org.). O novo processo civil. São Paulo: Lex, 2012.

ROSENBERG, Leo. La carga de la prueba. Tradução E. Krotoschin. 2. ed. Buenos Aires: B de F, 2002.

SALLES, Carlos Alberto de. Transição paradigmática na prova processual civil. In: ASSIS, Araken de (Org.). Direito civil e processo: estudos em homenagem ao Professor Arruda Alvim, São Paulo: RT, 2007.

SANTOS, Ernane Fidélis dos. O ônus da prova no Código de Defesa do Consumidor. Revista de Direito do Consumidor, São Paulo: RT, v. 12, n. 47, jul.-set. 2003.

SANTOS, Gildo dos. A prova no processo civil. 4. ed. São Paulo: RT, 2010.

SANTOS, José Carlos van Cleef de Almeida. O ônus da prova e a teoria da carga dinâmica. Revista dos Tribunais, São Paulo: RT, v. 101, n. 924, out. 2012.

SANTOS, Sandra Aparecida Sá dos. A inversão do ônus da prova. 2. ed. São Paulo: RT, 2006.

SCOZZAFAVA, Oberdan Tommaso. Verbete “onere”. Enciclopedia del Diritto. Milano: Giuffrè, 1980.30 .

SICA, Heitor Vitor Mendonça. $O$ direito de defesa no processo civil brasileiro: um estudo sobre a posição do réu. São Paulo: Atlas, 2011.

—. Preclusão processual civil. São Paulo: Atlas, 2006.

—. Questões velhas e novas sobre a inversão do ônus da prova (CDC, art. 6. $\left.{ }^{\circ}, \mathrm{VIII}\right)$. Revista de Processo, São Paulo: RT, v. 32, n. 146, abr. 2007.

SILVEIRA, Bruna Braga da. Notas sobre a teoria dinâmica do ônus da prova. Revista de Direito Privado, São Paulo, v. 13, n. 52, out.-dez. 2012.

SOUSA, Miguel Teixeira de. Estudos sobre o novo processo civil. 2. ed. Lisboa: Lex, 1997.

SRUNG, Rainer. Os fundamentos do direito processual civil austríaco. Revista de Processo, São Paulo: RT, v. 5, n. 17, jan.-mar. 1980. 
TARTUCE, Fernanda. Igualdade e vulnerabilidade no processo civil. Rio de Janeiro: Forense, 2012.

TARUFFO, Michele. O ônus como figura processual. Revista Eletrônica de Direito Processual, Rio de Janeiro, ano 7, v. 11, jan.-jun. 2013. Disponível em: <http://www.redp.com.br/arquivos/redp_11a_edicao.pdf $>$.

—. Uma simples verdade: o juiz e a construção dos fatos. Tradução V. P. Ramos. São Paulo: Marcial Pons Brasil, 2012.

THEODORO JÚNIOR. Humberto. Curso de direito processual civil. 51. ed. Rio de Janeiro: Forense, 2010, v. 1.

TORNAGHI, Hélio. Comentários ao Código de Processo Civil. São Paulo: RT, 1974. v. 1, p. 302.

VERDE, Giovanni. L'onere della prova nel proceso civile. Napoli: Jovene, 1974.

WALTER, Gerhard. Libre apreciación de la prueba: investigación acerca del significado, las condiciones y límites del libre convencimiento judicial. Bogotá: Temis, 1985.

WAMBIER, Teresa Arruda Alvim. Noções gerais sobre o processo no Código do Consumidor. Revista de direito do consumidor. São Paulo: Revista dos Tribunais, n. 10, abr./jun., 1994.

Reflexões sobre o ônus da prova. Revista de Processo. São Paulo: Revista dos Tribunais, v. 19, n. 76, out./dez., 1994.

WATANABE, Kazuo. Da cognição no processo civil. 4. ed. São Paulo: Saraiva, 2012.

YARSHELL, Flávio Luiz. Antecipação da prova sem o requisito da urgência e direito autônomo à prova. São Paulo: Malheiros, 2009.

YOSHIKAWA, Eduardo Henrique de Oliveira. (Ainda e sempre) o momento de inversão do ônus da prova. Revista Dialética de Direito Processual, São Paulo: Dialética, n. 60, p. 28-37, mar. 2008.

—. Considerações sobre a teoria da distribuição dinâmica do ônus da prova. Revista de Processo, São Paulo: RT, v. 37, n. 205, mar. 2012.

ZANETI, Paulo Rogério. Flexibilização das regras sobre o ônus da prova. São Paulo: Malheiros, 2011.

ZANFERDINI, Flávia de Almeida Montingelli; GOMES, Alexandre Gir. Cargas probatórias dinâmicas no processo civil brasileiro. Revista Dialética de Direito Processual, São Paulo, n. 69, dez. 2008. 